\title{
National Accounts at a Glance 2009
}



National Accounts at a Glance 2009

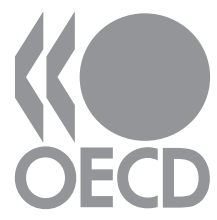




\section{ORGANISATION FOR ECONOMIC CO-OPERATION AND DEVELOPMENT}

The OECD is a unique forum where the governments of 30 democracies work together to address the economic, social and environmental challenges of globalisation. The OECD is also at the forefront of efforts to understand and to help governments respond to new developments and concerns, such as corporate governance, the information economy and the challenges of an ageing population. The Organisation provides a setting where governments can compare policy experiences, seek answers to common problems, identify good practice and work to co-ordinate domestic and international policies.

The OECD member countries are: Australia, Austria, Belgium, Canada, the Czech Republic, Denmark, Finland, France, Germany, Greece, Hungary, Iceland, Ireland, Italy, Japan, Korea, Luxembourg, Mexico, the Netherlands, New Zealand, Norway, Poland, Portugal, the Slovak Republic, Spain, Sweden, Switzerland, Turkey, the United Kingdom and the United States. The Commission of the European Communities takes part in the work of the OECD.

OECD Publishing disseminates widely the results of the Organisation's statistics gathering and research on economic, social and environmental issues, as well as the conventions, guidelines and standards agreed by its members.

This work is published on the responsibility of the Secretary-General of the OECD. The opinions expressed and arguments employed herein do not necessarily reflect the official views of the Organisation or of the governments of its member countries.

ISBN 978-92-64-06721-9 (print),

ISBN 978-92-64-06798-1 (PDF),

ISBN 978-92-64-07510-8 (HTML),

DOI 10.1787/9789264067981-en

Also available in French under the title: Panorama des comptes nationaux 2009]

Photo credit: @ Yahia Loukkal, Fotolia.com

Corrigenda to OECD publications may be found on line at: www.oecd.org/publishing/corrigenda. $\square$

(c) OECD 2009

You can copy, download or print OECD content for your own use, and you can include excerpts from OECD publications, databases and multimedia products in your own documents, presentations, blogs, websites and teaching materials, provided that suitable acknowledgment of OECD as source and copyright owner is given. All requests for public or commercial use and translation rights should be submitted to rights@oecd.org. Requests for permission to photocopy portions of this material for public or commercial use shall be addressed directly to the Copyright Clearance Center (CCC) at info@copyright.com or the Centre français d'exploitation du droit de copie (CFC) at contact@cfcopies.com. 


\section{Foreword}

$\mathrm{N}$ ational Accounts at a Glance is a new publication in the suite of national accounts publications produced by the OECD. Readers will immediately notice that the presentation of statistics is significantly different from the presentation of the other national accounts publications which focuses primarily on tabular presentations. Instead, this publication presents information using an "indicator" approach, focusing on cross-country comparisons; the aim being to make the accounts more accessible and informative, whilst, at the same time, taking the opportunity to present the conceptual underpinning of, and comparability issues inherent in, each of the indicators presented.

The range of indicators is set deliberately wide to reflect the richness of the national accounts dataset and to encourage users of economic statistics to refocus some of the spotlight that is often placed on GDP to other important economic indicators, which may better respond to their needs. Indeed many users themselves have been instrumental in this regard. The report of the Commission on the Measurement of Economic Performance and Social Progress (Stiglitz-Sen-Fitoussi Commission) is but one notable example.

That is not to undermine the importance of GDP, which arguably remains the most important measure of total economic activity but other measures may better reflect other aspects of the economy. For example, net national income, may be a more appropriate measure of income available to citizens in countries with large outflows of property income or remittances and household adjusted disposable income per capita may be a better indicator of the material well-being of citizens. But certainly from a data perspective more can and remains to be done. The Stiglitz-Sen-Fitoussi Commission for example highlights the pressing need for the provision, by official statistics institutes, of more detailed information that better describes the distributional aspects of activity, especially income, and the need to build on the national accounts framework to address issues such as non-market services produced by households or leisure. It is hoped that by producing a publication such as this, so raising awareness, the momentum from this and other initiatives will be accelerated. The publication itself will pick up new indicators in the future as they become available at the OECD.

The publication is broken down into six chapters: The first provides a general introduction focusing on indicators of GDP. The second focuses on income and presents a number of important indicators such as savings and net lending/net borrowing rates. Chapter 3 looks at indicators related to the expenditure approach to GDP estimation, with information on the key components of demand and imports. Chapter 4 looks at indicators from a production perspective. Chapters 5 and 6 focus on General Government and Capital respectively. Finally the annex provides important reference indicators, important in their ownright but also because they are used in the construction of many of the indicators presented elsewhere in the publication. It also provides further background on the new 2008 System of National Accounts, which will eventually be the basis of data published here. In the meantime, and the short-term, national statistics institutes will continue to compile their national accounts on the basis of the 1993 System of National accounts, which forms the conceptual basis of this publication. 



\section{Table of Contents}

Reader's Guide........................................ 9

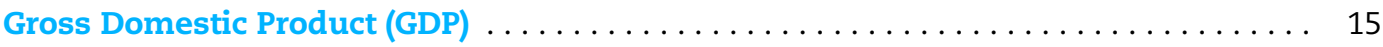

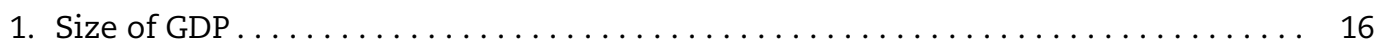

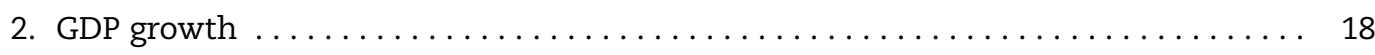

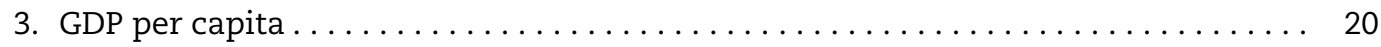

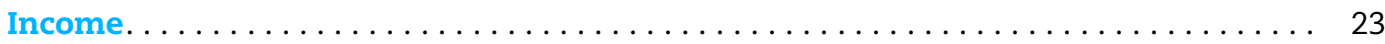

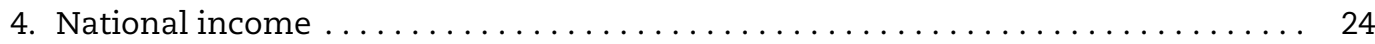

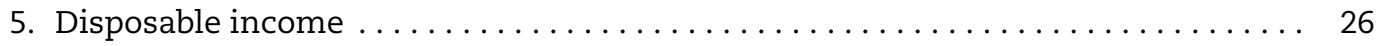

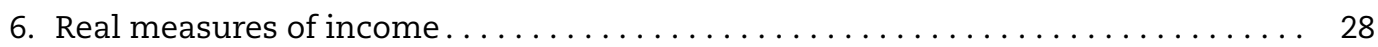

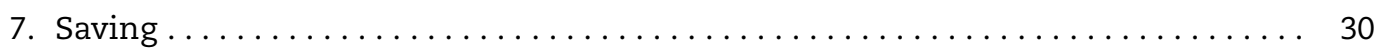

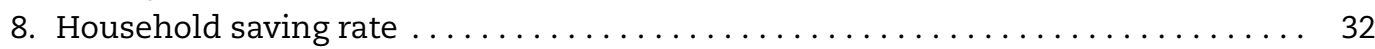

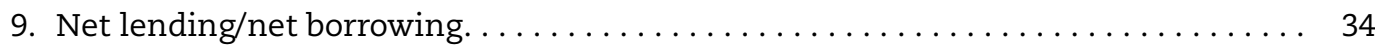

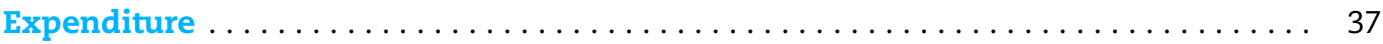

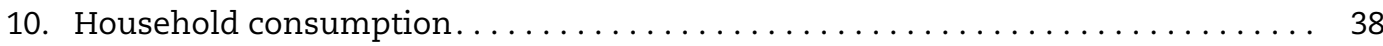

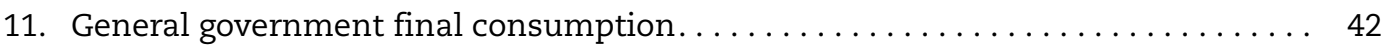

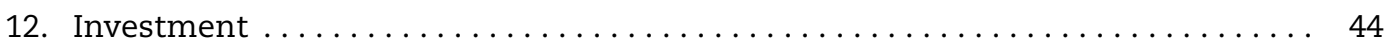

13. Exports and imports of goods and services $\ldots \ldots \ldots \ldots \ldots \ldots \ldots \ldots \ldots \ldots$

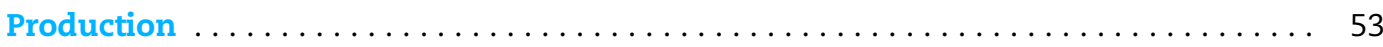

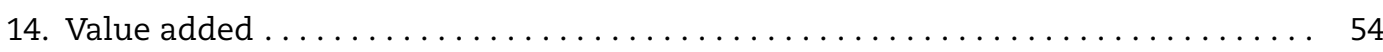

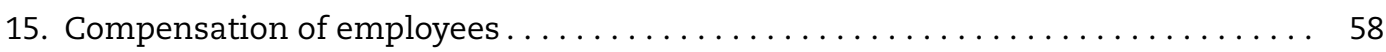

General Government. ................................... 61

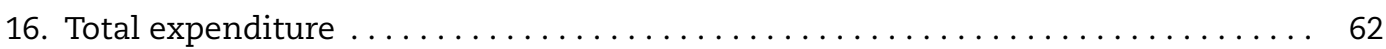

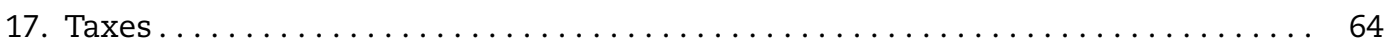

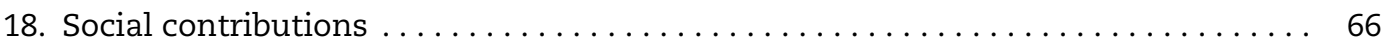

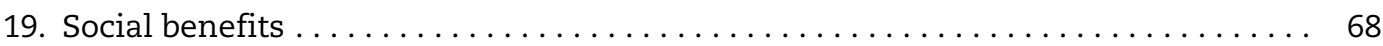

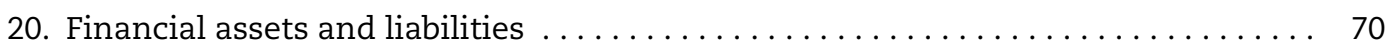

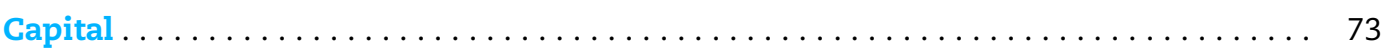

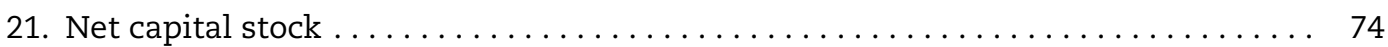

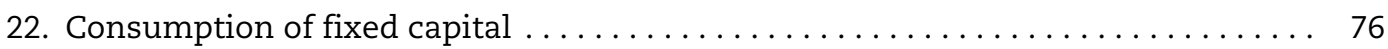

23. Non-financial assets held by households $\ldots \ldots \ldots \ldots \ldots \ldots \ldots \ldots \ldots \ldots \ldots \ldots$

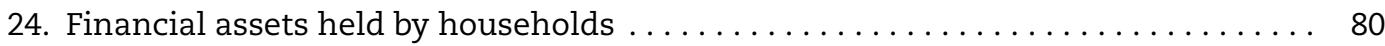

Annexes

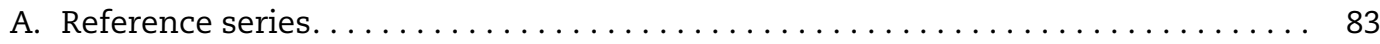

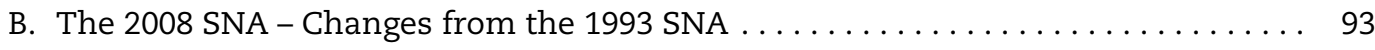

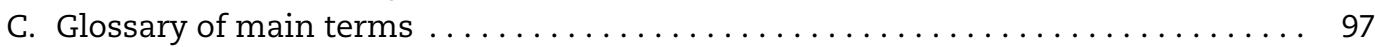


Tables

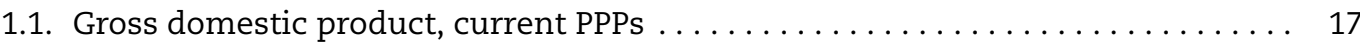

2.1. Gross domestic product, volume.......................... 19

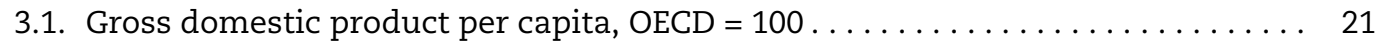

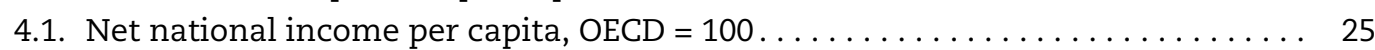

5.1. Household gross adjusted disposable income per capita $\ldots \ldots \ldots \ldots \ldots \ldots .27$

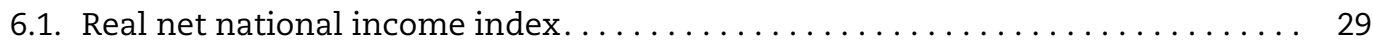

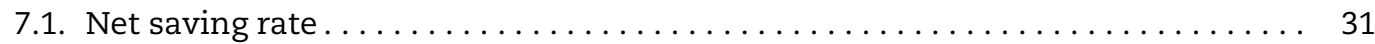

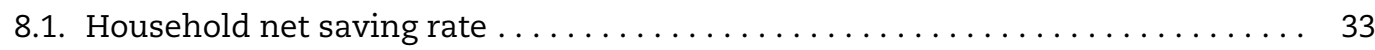

9.1. Net lending/net borrowing by institutional sector $\ldots \ldots \ldots \ldots \ldots \ldots \ldots \ldots \ldots$

10.1. Household final and actual individual consumption. . . . . . . . . . . 39

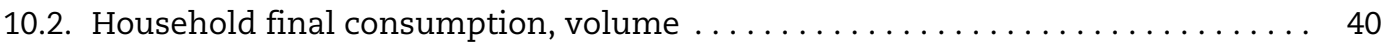

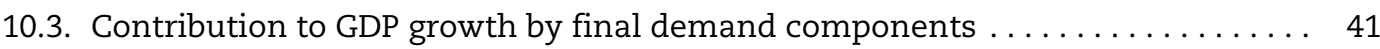

11.1. General government final consumption expenditure $\ldots \ldots \ldots \ldots \ldots \ldots \ldots . \ldots 4$

12.1. Gross fixed capital formation, volume $\ldots \ldots \ldots \ldots \ldots \ldots \ldots \ldots \ldots \ldots \ldots \ldots \ldots$

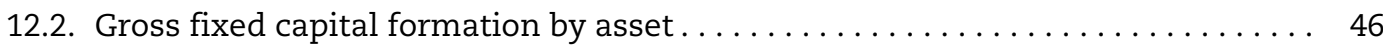

12.3. Gross fixed capital formation by institutional sector. . . . . . . . . . . 47

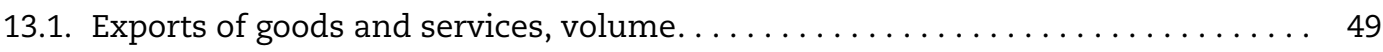

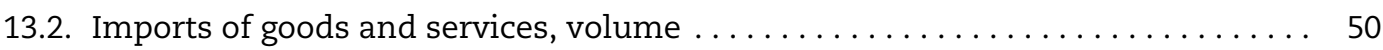

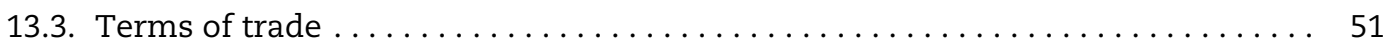

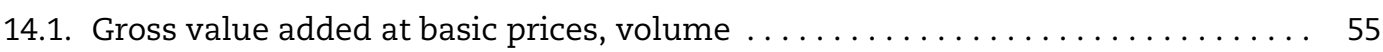

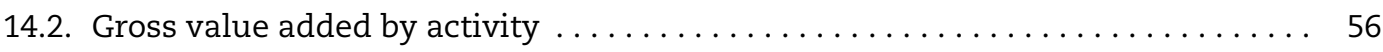

14.3. Contribution to gross value added growth by activity . . . . . . . . . 57

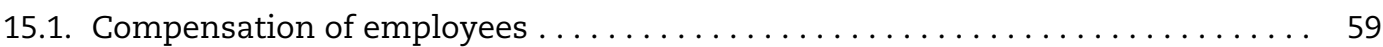

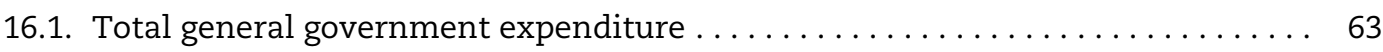

17.1. Taxes in the System of National Accounts (SNA) $\ldots \ldots \ldots \ldots \ldots \ldots \ldots \ldots \ldots$

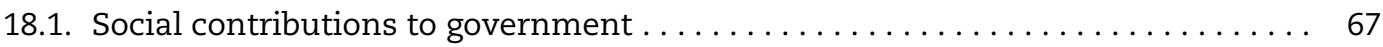

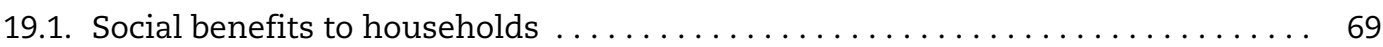

20.1. Financial assets and liabilities of general government $\ldots \ldots \ldots \ldots \ldots \ldots \ldots \quad 71$

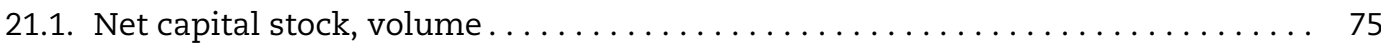

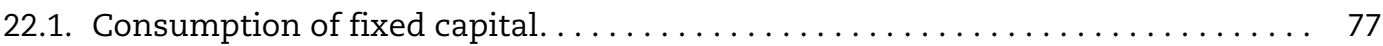

23.1. Non-financial assets of households per capita . . . . . . . . . . . . . . 79

24.1. Financial assets of households by type of assets $\ldots \ldots \ldots \ldots \ldots \ldots \ldots \ldots \ldots$

A.1. Gross domestic product, 2000 constant PPPs.................... 84

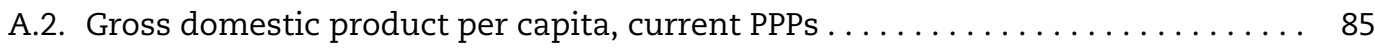

A.3. Gross domestic product per capita, 2000 constant PPPs . . . . . . . . . . 86

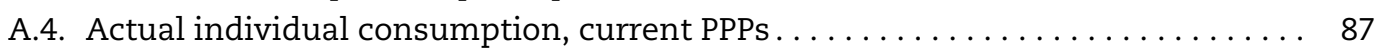

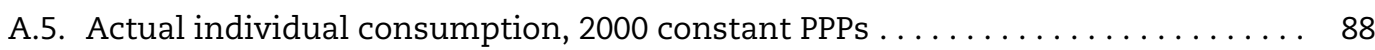

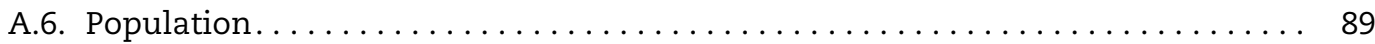

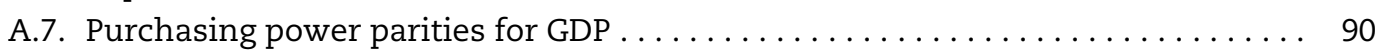

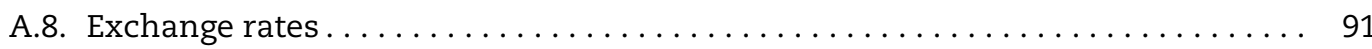

Figures

1.1. Gross domestic product: current exchange rates and current PPPs . . . . . . 17

2.1. Gross domestic product, volume......................... 19

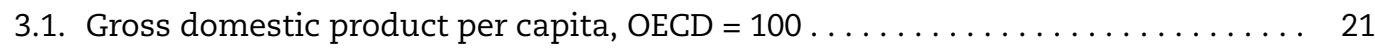

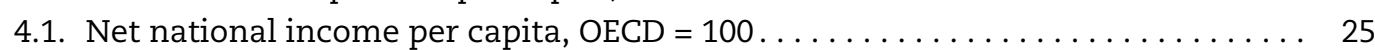


5.1. Disposable income - gross and gross adjusted - by sector $\ldots \ldots \ldots \ldots \ldots \ldots 27$

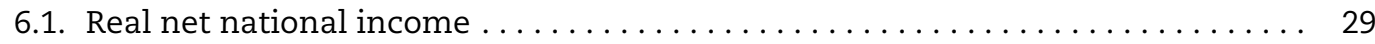

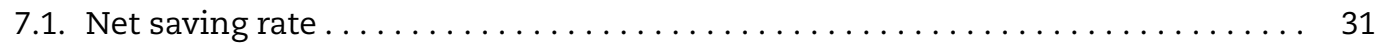

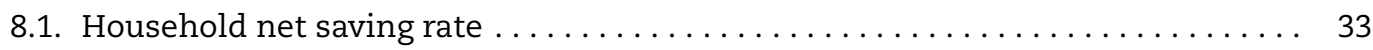

9.1. Net lending/net borrowing by institutional sector $\ldots \ldots \ldots \ldots \ldots \ldots \ldots \ldots \ldots$

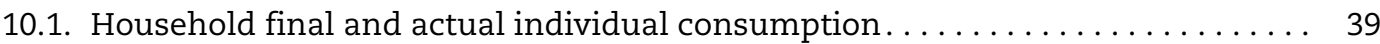

10.2. Household final and actual individual consumption per capita, $\mathrm{OECD}=100 \ldots 40$

10.3. Contribution to GDP growth by final demand components ............ 41

11.1. General government final consumption $\ldots \ldots \ldots \ldots \ldots \ldots \ldots \ldots \ldots \ldots \ldots \ldots \ldots \ldots$

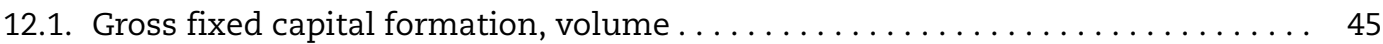

12.2. Information and communication technologies (ICT) investment . . . . . . . 46

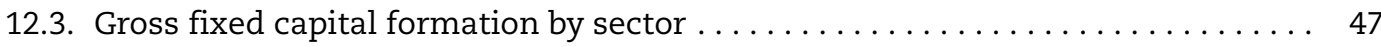

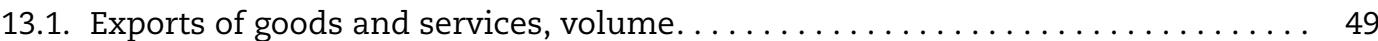

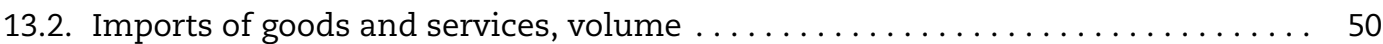

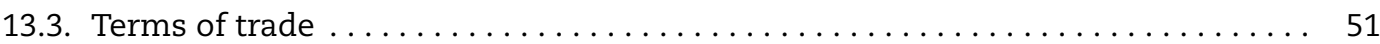

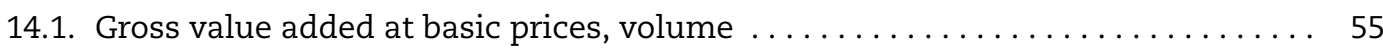

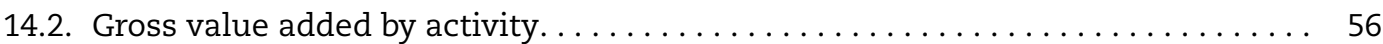

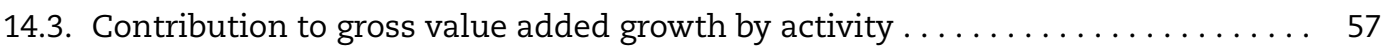

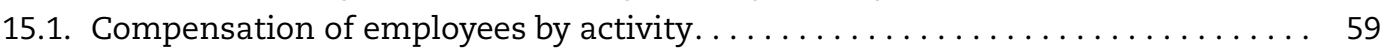

16.1. Total general government expenditure by main component $\ldots \ldots \ldots \ldots \ldots \ldots .63$

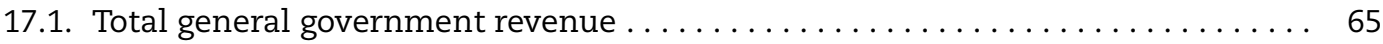

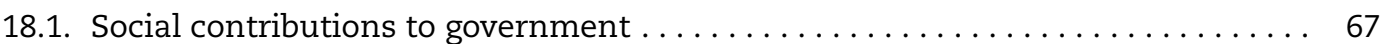

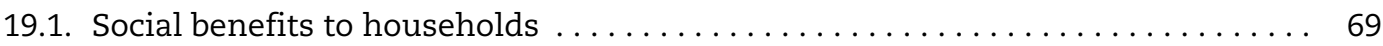

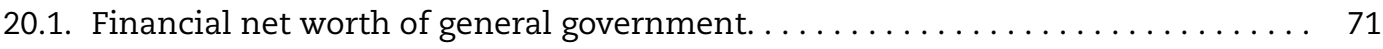

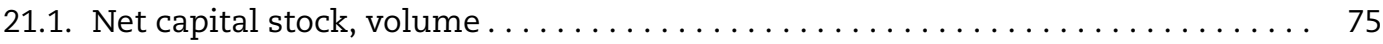

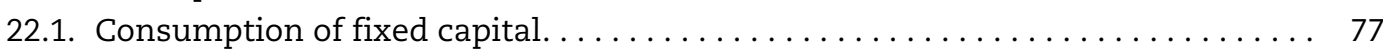

24.1. Financial assets of households per capita $\ldots \ldots \ldots \ldots \ldots \ldots \ldots \ldots \ldots \ldots \ldots$

\section{This book has...}

\section{StatLinks 初 A service that delivers Excel $^{\circledR}$ files from the printed page!}

Look for the StatLinks at the bottom right-hand corner of the tables or graphs in this book. To download the matching Excel ${ }^{\circledR}$ spreadsheet, just type the link into your Internet browser, starting with the http://dx.doi.org prefix.

If you're reading the PDF e-book edition, and your PC is connected to the Internet, simply click on the link. You'll find StatLinks appearing in more OECD books. 



\section{READER'S GUIDE}

\section{Main features}

Each indicator is preceded by a short text that opens with an explanation in general terms of what is measured and why. This is followed by a more detailed description of the underlying concept (Definition) consistent with the 1993 System of National Accounts (SNA). The final paragraph (Comparability) highlights those areas where some caution may be needed when comparing performance across countries or over time. Some issues relating to comparability, or the care that should be taken when making comparisons, cut across a number of subject areas. Rather than refer to these each time they arise these generic cases are described below.

\section{SNA - Standard definitions}

Data included in this publication are compiled according to the 1993 SNA "System of National Accounts, 1993"; jointly prepared by the Commission of the European Communities, the International Monetary Fund, the Organisation for Economic Co-operation and Development, the United Nations and the World Bank.

\section{SNA - Changes from the 1993 SNA}

The 2008 SNA has been finalised but it will be a number of years before most OECD countries are in a position to provide statistics on the basis of the new system. Key changes from the 1993 SNA are presented in the annex.

\section{Questionnaires and source data}

Unless otherwise specified all data have been provided by countries via standardised OECD questionnaires.

\section{Statistical conventions}

- All growth rates refer to constant prices (or real) data.

- Ratios, percentages and shares are derived from current prices data.

- Contribution of $\mathrm{Y}$ to the growth of $\mathrm{X}$ ( $\mathrm{Y}$ being a component of $\mathrm{X}$ ) is defined as the growth rate of $\mathrm{Y}$ (chained or fixed constant prices) weighted by the share of $\mathrm{Y}$ in $\mathrm{X}$ at current prices (period t-1).

\section{Signs and abbreviations}

.. Missing values, not applicable or not available

e OECD estimates

\section{Countries and zones}

Data are available for most indicators for all OECD countries. Where data are not available or have not been provided to the OECD, estimates are often produced. 


\section{OECD total}

OECD total refers to all OECD countries unless otherwise specified.

\section{Euro area}

Data for the zone "Euro area" are taken from Eurostat databases.

\section{Data in euros}

Data for all member countries of the European Monetary Union (EMU) are expressed in euros.

Data relating to years prior to entry into the EMU have been converted from the former national currency using the appropriate irrevocable conversion rate. This presentation facilitates comparisons within a country over time and ensures that the historical evolution (i.e. growth rates) is preserved. However, pre-EMU Euros are a notional unit and are not normally suitable to form area aggregates or to carry out cross-country comparisons.

\section{OECD accession countries}

The OECD is working towards its enlargement. In 2007 five countries were selected with a view to becoming new members: Chile, Estonia, Israel, the Russian Federation and Slovenia. The OECD is also engaging key global players in its work, such as Brazil, China, India, Indonesia and South Africa. Although data for these countries do not form part of this publication, some national accounts data for them are available on the OECD website. See below for more information on how to find the data online.

\section{General comments on concepts and comparability}

The list of comments described below relates to cross-cutting issues and is provided here to avoid repetition in the sections that follow.

\section{Purchasing power parities for GDP}

PPPs are the rates of currency conversion that equalise the purchasing power of different countries by eliminating differences in price levels between countries. When converted by means of PPPs, expenditures on GDP across countries are in effect expressed at the same set of prices, enabling comparisons between countries that reflect only differences in the volume of goods and services purchased. Simplistic comparisons of economic activity using exchange rates should generally be avoided as such comparisons will embody these price differences, and, moreover, exchange rate series tend to be more volatile than PPPs, presenting difficulties when comparing across countries and time.

However, a caveat related to international comparisons is still necessary in the context of PPPs. When countries are clustered around a very narrow range of outcomes, it may be misleading to establish a strict order of ranking. As is often the case with statistical information, there is a level of uncertainty associated with the data sources and procedures on which PPPs computations rely. Relatively minor differences between two country's PPP adjusted indicators, such as PPP adjusted GDP or NNI, may not be statistically or economically significant.

1995-1998: PPPs for all European countries are annual benchmark results provided by Eurostat. PPPs for all other countries are OECD estimates.

1999, 2002, and 2005: PPPs for all OECD countries are triennial benchmark results calculated jointly by the OECD and Eurostat.

2000-2001, 2003-2004, 2006, 2007: PPPs for all European countries are annual benchmark results provided by Eurostat. PPPs for all non-European countries are OECD estimates.

2008: PPPs for all European countries are preliminary annual benchmark results provided by Eurostat. PPPs for non-European countries are OECD estimates. Estimates and preliminary results should be interpreted with caution as they are subject to revision. 
More information is available on the PPP Internet site: www.oecd.org/std/ppp.

\section{Exchange rates}

The exchange rates used in this publication have been calculated by the International Monetary Fund, and are published in International Financial Statistics. They are market rates averaged over the year.

\section{Per capita indicators}

Many of the indicators that follow are shown on a per capita basis. It is important to note therefore that the underlying population estimates are based on the SNA notion of residency: namely they include persons who are resident in a country for one year or more, regardless of their citizenship, and also include foreign diplomatic personnel, defence personnel, together with their families, and students studying and patients seeking treatment abroad, even if they stay abroad for more than one year. The "one-year rule" means that usual residents who live abroad for less than one year are included in the population and foreign visitors (for example, holidaymakers) who are in the country for less than one year are not included.

An important point to note in this context is that individuals may feature as employees of one country, (contributing to the GDP of that country via production) but residents of another (with their wages and salaries reflected in the GNI of their resident country).

\section{Calendar/fiscal years}

Unless specified below, or in the text accompanying the section, all data are on the basis of calendar years.

Data for Australia and New Zealand refer to fiscal years - 1 July of the year indicated to 30 June for Australia and 1 April of the year indicated to 31 March for New Zealand.

\section{Volume (constant price) estimates}

Most OECD countries now produce their accounts using annual chain volume series. Mexico however currently produces fixed-base volume estimates with the base year updated at present less periodically (ten years at time of the last re-basing) and links created to earlier base year estimates.

The SNA recommends the production of estimates on the basis of annual chain volume series. These produce better estimates of growth as the weights used for the contribution of different goods and services are more relevant to the period in question. There is one downside to (annual) chaining however: aggregates may not equal the sum of their components in volume terms.

\section{Gross and net values}

The term "gross" is a common means of referring to values before deducting consumption of fixed capital. But not all references to "net" are necessarily in the context of net of depreciation. The reference to "net lending/borrowing" is the relevant example in this publication where "net" is not in the context of "depreciation".

\section{Households and NPISHs}

A number of countries are not able to provide a breakdown of Households and Non-profit Institutions serving Households (NPISHs) in their sector accounts. As a consequence, to ensure the highest level of comparability, unless otherwise specified, the accounts for the households sector include NPISHs in this publication. 


\section{Important equalities in the SNA}

Gross domestic product (GDP) at market prices

$=$ Final consumption expenditure

+ Gross capital formation

+ Exports of goods and services

- Imports of goods and services

= Gross value added at basic prices

+ Taxes less subsidies on products

\section{Net national income (NNI) at market prices}

$=\mathrm{GDP}$ at market prices

+ Taxes less subsidies on production and imports (net, receivable from abroad)

+ Compensation of employees (net, receivable from abroad)

+ Property income (net, receivable from abroad)

- Consumption of fixed capital

\section{Net national disposable income (NNDI)}

$=$ NNI at market prices

+ Current taxes on income, wealth, etc. (net, receivable from abroad)

+ Social contributions and benefits and other current transfers (net, receivable from abroad)

\section{Saving, net}

$=$ NNDI at market prices

- Final consumption expenditure

+ Adjustment for the change in net equity of households on pension entitlements (net, receivable from abroad)

\section{Net lending/net borrowing}

$=$ Saving, net

+ Capital transfers (net, receivable from abroad)

- Gross capital formation

- Acquisitions less disposals of non-produced non-financial assets

+ Consumption of fixed capital

\section{Further reading}

Useful references for "further reading" are available at the bottom of most sections. in:

For all sections, general information on methodology and detailed definitions can be found

- UN, OECD, IMF, Eurostat (eds.) (1993), System of National Accounts 1993, United Nations, Geneva, http://unstats.un.org/unsd/sna1993.

Extracts of the SNA publication are available in:

- OECD (2000), OECD Glossaries, System of National Accounts, 1993 - Glossary, OECD, Paris.

Finally, additional information and complementary tables can be found in:

- OECD (2009), Factbook, OECD, Paris. 


\section{Online data}

\section{National Accounts at a Glance - Database edition}

The database edition of National Accounts at a Glance is continuously updated on line and contains longer time series than the publication: $h t t p: / / d x . d o i . o r g / 10.1787 / d a t a-00369-e n$. Data are available as far back as 1970 for some countries.

An inventory of the series published in National Accounts at a Glance is available on line. The inventory includes the titles of the individual time series along with the corresponding database codes. This inventory may be accessed via: www.oecd.org/statistics/nationalaccounts/ataglance.

\section{Detailed National Accounts data}

The National Accounts at a Glance dataset is published as part of the OECD National Accounts Statistics online database which can be accessed via $h t t p: / / d x$.doi.org/10.1787/na-data-en. This database includes very detailed information from the annual national accounts as well as financial and general government accounts.

The following is a list of the datasets which are available:

\section{Aggregate national accounts}

- Gross domestic product

- Disposable income and net lending/borrowing

- Population and employment by main activity

- PPPs and exchange rates

\section{Detailed national accounts}

- Balance sheets for non-financial assets

- Capital formation by activity

- Final consumption expenditure of households

- Fixed assets by activity and by type of product

- Labour input by activity

- Non-financial accounts by sectors

- Simplified non-financial accounts

- Value added and its components by activity

\section{Financial accounts}

- Consolidated flows

- Non-consolidated flows

- Financial balance sheets

- Consolidated stocks

- Non-consolidated stocks

\section{General government accounts}

- Government expenditure by function

- Maastricht debt

- Main aggregates

- Taxes and social contributions receipts 
Gross domestic product (GDP) is the standard measure of the value of final goods and services produced by a country during a period. While GDP is the single most important indicator to capture these economic activities, it is not a good measure of societies' well-being and only a limited measure of people's material living standards. The sections and indicators that follow better address this and other related issues and this is one of the primary purposes of this publication.

Countries calculate GDP in their own currencies. In order to compare across countries these estimates have to be converted into a common currency. Often the conversion is made using current exchange rates but these can give a misleading comparison of the true volumes of final goods and services in GDP. A better approach is to use purchasing power parities (PPPs). PPPs are currency converters that control for differences in the price levels of products between countries and so allow an international comparison of the volumes of GDP and of the size of economies.

\section{Definition}

What does gross domestic product mean? "Gross" signifies that no deduction has been made for the depreciation of machinery, buildings and other capital products used in production. "Domestic" means that it is production by the resident institutional units of the country. The products refer to final goods and services, that is, those that are purchased, imputed or otherwise, as: the final consumption of households, non-profit institutions serving households and government; fixed assets; and exports (minus imports).

GDP at market prices can be measured in three different ways:

- as output less intermediate consumption (i.e. value added) plus taxes on products (such as VAT) less subsidies on products;

- as the income earned from production, equal to the sum of: employee compensation; the gross operating surplus of enterprises and government; the gross mixed income of unincorporated enterprises; and net taxes on production and imports (VAT, payroll tax, import duties, etc., less subsidies);

- or as the expenditure on final goods and services minus imports: final consumption expenditures, gross capital formation, and exports less imports.

\section{Comparability}

All OECD countries now follow the 1993 System of National Accounts, although in some countries, for example in specific areas such as the own account production of software or financial intermediation services (indirectly measured) (FISIM), differences remain, which can impact on comparisons of GDP. The measurement of the non-observed economy (NOE, often referred to as the informal, grey, shadow, economy) can also have an impact on comparability, although for OECD economies, in general, this is not thought to be significant. (See also "Reader's Guide", relating to PPP based comparisons.)

For some countries, the latest year has been estimated by the Secretariat. Historical data have also been estimated for those countries that revise their methodologies but only supply revised data for some years. This estimation process mechanically links the new and old series to preserve growth rates.

\section{Source}

- OECD (2009), National Accounts of OECD Countries 2009, Volume I, Main Aggregates, OECD Publishing, http://dx.doi.org/10.1787/na_vol_1-2009-en-fr.

\section{Online database}

- OECD (2009), "Aggregate national accounts: gross domestic product", OECD National Accounts Statistics (database), http://dx.doi.org/10.1787/data-00001-en.

\section{Further reading}

- Lequiller F., N. Ahmad, S. Varjonen, W. Cave and K.-H. Ahn (2003), Report of the OECD Task Force on Software Measurement in the National Accounts, OECD Publishing, http://dx.doi.org/10.1787/334811030426.

- Ahmad N. (2003), Measuring Investment in Software, OECD Publishing,

http://dx.doi.org/10.1787/335303788330.

- OECD (2002), Measuring the Non-Observed Economy: A Handbook, OECD Publishing, http://dx.doi.org/10.1787/9789264175358-en.

- Lequiller F. and D. Blades (2007), Understanding National Accounts, OECD Publishing, http://dx.doi.org/10.1787/9789264027657-en.

- OECD (2000), System of National Accounts, 1993 Glossary, OECD Publishing, http://dx.doi.org/10.1787/9789264180871-en.

- UN, OECD, IMF, Eurostat (eds.) (1993), System of National Accounts 1993, United Nations, Geneva, http://unstats.un.org/unsd/sna1993. 
Table 1.1. Gross domestic product, current PPPs

Billion US dollars

\begin{tabular}{|c|c|c|c|c|c|c|c|c|c|c|c|c|c|c|}
\hline & 1995 & 1996 & 1997 & 1998 & 1999 & 2000 & 2001 & 2002 & 2003 & 2004 & 2005 & 2006 & 2007 & 2008 \\
\hline Australia & 392 & 412 & 437 & 464 & 497 & 525 & 552 & 585 & 622 & 656 & 697 & 743 & 795 & $830 \mathrm{e}$ \\
\hline Austria & 187 & 194 & 199 & 208 & 216 & 230 & 232 & 244 & 252 & 266 & 275 & 291 & 309 & 316 \\
\hline Belgium & 228 & 232 & 243 & 248 & 259 & 282 & 292 & 309 & 313 & 323 & 336 & 354 & 376 & 374 \\
\hline Canada & 667 & 691 & 732 & 771 & 825 & 873 & 910 & 938 & 990 & 1050 & 1131 & 1204 & 1270 & $1303 \mathrm{e}$ \\
\hline Czech Republic & 133 & 141 & 143 & 144 & 147 & 154 & 165 & 172 & 184 & 197 & 208 & 226 & 248 & 257 \\
\hline Denmark & 120 & 127 & 134 & 139 & 143 & 154 & 158 & 165 & 164 & 175 & 180 & 190 & 196 & 200 \\
\hline Finland & 96 & 99 & 108 & 117 & 122 & 133 & 138 & 143 & 144 & 156 & 161 & 172 & 184 & 188 \\
\hline France & 1204 & 1243 & 1302 & 1369 & 1425 & 1533 & 1630 & 1711 & 1701 & 1768 & 1869 & 1961 & 2081 & 2115 \\
\hline Germany & 1840 & 1892 & 1936 & 1990 & 2064 & 2130 & 2212 & 2275 & 2358 & 2468 & 2587 & 2709 & 2835 & 2928 \\
\hline Greece & 156 & 163 & 173 & 179 & 185 & 201 & 218 & 237 & 250 & 267 & 274 & 294 & 316 & 324 \\
\hline Hungary & 93 & 97 & 104 & 111 & 115 & 124 & 138 & 150 & 156 & 165 & 171 & 181 & 189 & 193 \\
\hline Iceland & 6 & 7 & 7 & 8 & 8 & 8 & 9 & 9 & 9 & 10 & 10 & 11 & 11 & 12 \\
\hline Ireland & 65 & 71 & 80 & 89 & 97 & 109 & 118 & 130 & 138 & 148 & 160 & 177 & 195 & 186 \\
\hline Italy & 1202 & 1242 & 1285 & 1351 & 1377 & 1456 & 1546 & 1532 & 1564 & 1596 & 1649 & 1737 & 1813 & 1849 \\
\hline Japan & 2831 & 2964 & 3061 & 3032 & 3071 & 3246 & 3331 & 3417 & 3510 & 3710 & 3873 & 4081 & 4293 & $4356 \mathrm{e}$ \\
\hline Korea & $603 \mathrm{e}$ & $657 \mathrm{e}$ & $699 \mathrm{e}$ & $658 \mathrm{e}$ & $731 \mathrm{e}$ & 806 & 860 & 936 & 964 & 1041 & 1097 & 1195 & 1300 & 1358 \\
\hline Luxembourg & 16 & 17 & 17 & 18 & 21 & 23 & 24 & 26 & 27 & 30 & 32 & 36 & 40 & 41 \\
\hline Mexico & $688 \mathrm{e}$ & $737 \mathrm{e}$ & $800 \mathrm{e}$ & 849 e & $894 \mathrm{e}$ & $986 \mathrm{e}$ & $1009 \mathrm{e}$ & $1048 \mathrm{e}$ & 1108 & 1186 & 1294 & 1402 & 1485 & $1537 \mathrm{e}$ \\
\hline Netherlands & 334 & 352 & 376 & 400 & 426 & 468 & 494 & 516 & 515 & 541 & 573 & 607 & 644 & 681 \\
\hline New Zealand & 64 & 67 & 70 & 71 & 76 & 80 & 85 & 89 & 93 & 99 & 103 & 109 & 115 & $115 \mathrm{e}$ \\
\hline Norway & 103 & 114 & 123 & 122 & 133 & 162 & 167 & 168 & 175 & 194 & 219 & 243 & 252 & 278 \\
\hline Poland & 287 & 311 & 340 & 363 & 383 & 404 & 419 & 442 & 458 & 497 & 526 & 566 & 614 & 674 \\
\hline Portugal & 131 & 137 & 146 & 154 & 164 & 175 & 183 & 191 & 196 & 201 & 218 & 229 & 242 & 246 \\
\hline Slovak Republic & 45 & 49 & 52 & 56 & 56 & 59 & 65 & 70 & 73 & 79 & 87 & 97 & 108 & 119 \\
\hline Spain & 631 & 661 & 701 & 751 & 792 & 857 & 920 & 994 & 1040 & 1109 & 1188 & 1304 & 1420 & 1447 \\
\hline Sweden & 193 & 200 & 207 & 215 & 229 & 246 & 249 & 259 & 269 & 289 & 292 & 313 & 335 & 344 \\
\hline Switzerland & 189 & 194 & 203 & 210 & 215 & 228 & 234 & 245 & 246 & 258 & 266 & 290 & 314 & 332 \\
\hline Turkey & $427 \mathrm{e}$ & $467 \mathrm{e}$ & $511 \mathrm{e}$ & 536 & 518 & 589 & 561 & 572 & 588 & 689 & 781 & 881 & 945 & 998 \\
\hline United Kingdom & 1146 & 1220 & 1308 & 1363 & 1423 & 1533 & 1631 & 1714 & 1778 & 1900 & 1969 & 2068 & 2167 & 2200 \\
\hline United States & 7359 & 7784 & 8279 & 8741 & 9301 & 9899 & 10234 & 10590 & 11089 & 11812 & 12580 & 13336 & 14011 & 14369 \\
\hline Euro area & 6178 & 6394 & 6664 & 6978 & 7256 & 7711 & 8131 & 8442 & 8636 & 9021 & 9483 & 10044 & 10644 & 10910 \\
\hline OECD-Total & $21438 \mathrm{e}$ & $22541 \mathrm{e}$ & $23775 \mathrm{e}$ & $24724 \mathrm{e}$ & $25914 \mathrm{e}$ & $27671 \mathrm{e}$ & $28784 \mathrm{e}$ & $29879 \mathrm{e}$ & 30977 & 32878 & 34805 & 37004 & 39103 & $40170 \mathrm{e}$ \\
\hline
\end{tabular}

StatLink ताIs http://dx.doi.org/10.1787/740520054135

\section{Figure 1.1. Gross domestic product: current exchange rates and current PPPs}

The seven largest economies in the OECD. Percentage of OECD total, 2008

Current exchange rates

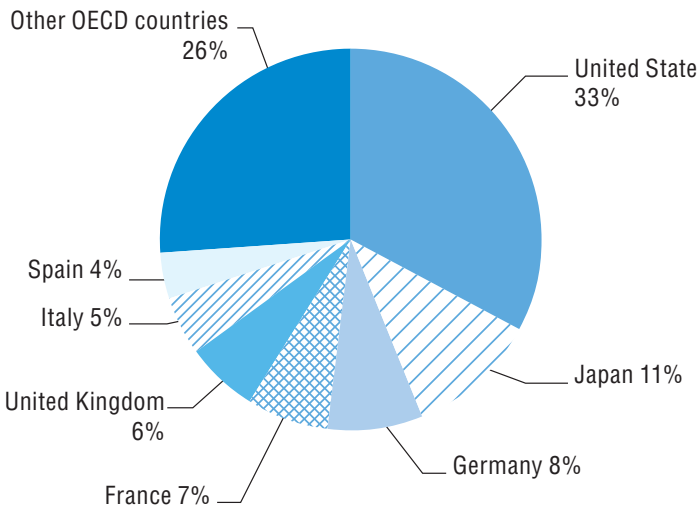

Current purchasing power parities (PPPs)

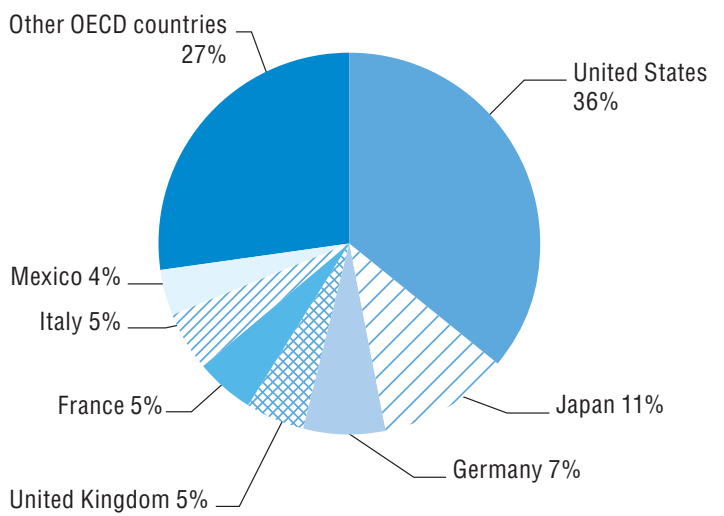

StatLink काIsय $h t t p: / / d x . d o i . o r g / 10.1787 / 738543187137$ 
Changes in the size of economies are usually measured by changes in the volume (often referred to as real) of GDP. Real reflects the fact that changes in GDP due to inflation are removed. This provides a measure of changes in the volume of production of an economy.

\section{Definition}

Converting nominal values of GDP to real values requires a set of detailed price indices, implicit or directly collected. When applied to the nominal value of transactions, the corresponding volume changes can be captured. The detailed volume changes for goods and services - typically several hundred - are then aggregated to yield an overall change in the volume of GDP. In the past, most countries used fixed weights for this aggregation and the base year to which weights related was only modified every five to ten years. It is important to recognise that growth rates are not invariant to the choice of this reference period and measures of growth could turn out to be biased for reporting years that were remote from the base year.

Since the 1993 System of National Accounts it has therefore been recommended that weights should be representative of the periods for which growth rates are calculated. This means that new weights should be introduced every year, giving rise to chain-linked (volume) indices (see Comparability, below).

\section{Comparability}

As described in Section 1, comparability of nominal values of GDP across countries is good. There is generally some variability in how countries calculate their volume estimates of GDP, particularly in respect of government consumption, but this doesn't necessarily mean that growth rates are less comparable.

With the exception of Mexico, all OECD countries derive their annual estimates of real GDP using annually chain-linked volume indices (that is the fixed prices/weights are updated every year). Mexico, like many non-OECD countries, revise their fixed weights less frequently - the last revision occurring after ten years. Such practices however tend to lead to biased growth rates, usually upward.

\section{Source}

- OECD (2009), National Accounts of OECD Countries 2009, Volume I, Main Aggregates, OECD Publishing, http://dx.doi.org/10.1787/na_vol_1-2009-en-fr.

\section{Online database}

- OECD (2009), “Aggregate national accounts: gross domestic product", OECD National Accounts Statistics (database),

http://dx.doi.org/10.1787/data-00001-en.

\section{Further reading}

- Ahmad N., F. Lequiller, P. Marianna, D. Pilat, P. Schreyer, A. Wölfl (2003), Comparing Labour Productivity Growth in the OECD Area: The Role of Measurement, OECD Publishing, http://dx.doi.org/10.1787/838342850485.

- Eurostat (2001), Handbook on Price and Volume Measures in National Accounts, Eurostat, Luxembourg.

- Lequiller, F. and D. Blades (2007), Understanding National Accounts, OECD Publishing, http://dx.doi.org/10.1787/9789264027657-en.

- OECD (2000), System of National Accounts, 1993 - Glossary, OECD Publishing, http://dx.doi.org/10.1787/9789264180871-en.

- UN, OECD, IMF, Eurostat (eds.) (1993), System of National Accounts 1993, United Nations, Geneva, http://unstats.un.org/unsd/sna1993. 
Table 2.1. Gross domestic product, volume

Annual growth rates in percentage

\begin{tabular}{|c|c|c|c|c|c|c|c|c|c|c|c|c|c|c|}
\hline & 1995 & 1996 & 1997 & 1998 & 1999 & 2000 & 2001 & 2002 & 2003 & 2004 & 2005 & 2006 & 2007 & 2008 \\
\hline Australia & 4.1 & 3.9 & 4.5 & 5.2 & 4.0 & 1.9 & 3.8 & 3.2 & 4.0 & 2.8 & 3.0 & 3.3 & 3.7 & $2.3 \mathrm{e}$ \\
\hline Austria & 2.5 & 2.2 & 2.1 & 3.6 & 3.3 & 3.7 & 0.5 & 1.6 & 0.8 & 2.5 & 2.5 & 3.5 & 3.5 & 2.0 \\
\hline Belgium & 2.4 & 1.2 & 3.5 & 1.7 & 3.4 & 3.7 & 0.8 & 1.5 & 1.0 & 3.0 & 1.8 & 3.0 & 2.8 & 1.1 \\
\hline Canada & 2.8 & 1.6 & 4.2 & 4.1 & 5.5 & 5.2 & 1.8 & 2.9 & 1.9 & 3.1 & 2.9 & 3.1 & 2.7 & $0.4 \mathrm{e}$ \\
\hline Czech Republic & 5.9 & 4.0 & -0.7 & -0.8 & 1.3 & 3.6 & 2.5 & 1.9 & 3.6 & 4.5 & 6.3 & 6.8 & 6.1 & 2.5 \\
\hline Denmark & 3.1 & 2.8 & 3.2 & 2.2 & 2.6 & 3.5 & 0.7 & 0.5 & 0.4 & 2.3 & 2.4 & 3.3 & 1.6 & -1.2 \\
\hline Finland & 3.9 & 3.7 & 6.2 & 5.2 & 3.9 & 5.1 & 2.7 & 1.6 & 1.8 & 3.7 & 2.8 & 4.9 & 4.2 & 1.0 \\
\hline France & 2.1 & 1.1 & 2.2 & 3.5 & 3.3 & 3.9 & 1.9 & 1.0 & 1.1 & 2.5 & 1.9 & 2.2 & 2.3 & 0.4 \\
\hline Germany & 1.9 & 1.0 & 1.8 & 2.0 & 2.0 & 3.2 & 1.2 & 0.0 & -0.2 & 1.2 & 0.8 & 3.2 & 2.5 & 1.3 \\
\hline Greece & $2.1 \mathrm{e}$ & $2.4 \mathrm{e}$ & $3.6 \mathrm{e}$ & $3.4 \mathrm{e}$ & $3.4 \mathrm{e}$ & $4.5 \mathrm{e}$ & 4.2 & 3.4 & 5.9 & 4.6 & 2.2 & 4.5 & 4.5 & 2.0 \\
\hline Hungary & 1.5 & 1.0 & 4.3 & 5.2 & 4.2 & 4.9 & 4.1 & 4.4 & 4.3 & 4.9 & 3.5 & 4.0 & 1.0 & 0.6 \\
\hline Iceland & 0.1 & 4.8 & 4.9 & 6.3 & 4.1 & 4.3 & 3.9 & 0.1 & 2.4 & 7.7 & 7.4 & 4.5 & 5.5 & 0.3 \\
\hline Ireland & 9.6 & 8.1 & 11.5 & 8.4 & 10.7 & 9.4 & 5.7 & 6.5 & 4.4 & 4.6 & 6.2 & 5.4 & 6.0 & -3.0 \\
\hline Italy & 2.8 & 1.1 & 1.9 & 1.4 & 1.5 & 3.7 & 1.8 & 0.5 & -0.0 & 1.5 & 0.7 & 2.0 & 1.6 & -1.0 \\
\hline Japan & 2.0 & 2.7 & 1.6 & -2.0 & -0.1 & 2.9 & 0.2 & 0.3 & 1.4 & 2.7 & 1.9 & 2.0 & 2.4 & $-0.7 \mathrm{e}$ \\
\hline Korea & $9.2 \mathrm{e}$ & $7.0 \mathrm{e}$ & $4.7 \mathrm{e}$ & $-6.9 \mathrm{e}$ & $9.5 \mathrm{e}$ & $8.5 \mathrm{e}$ & 4.0 & 7.2 & 2.8 & 4.6 & 4.0 & 5.2 & 5.1 & 2.2 \\
\hline Luxembourg & 1.4 & 1.5 & 5.9 & 6.5 & 8.4 & 8.4 & 2.5 & 4.1 & 1.5 & 4.4 & 5.4 & 5.6 & 6.5 & 0.0 \\
\hline Mexico & $-6.2 \mathrm{e}$ & $5.2 \mathrm{e}$ & $6.8 \mathrm{e}$ & $5.0 \mathrm{e}$ & $3.8 \mathrm{e}$ & $6.6 \mathrm{e}$ & $-0.0 \mathrm{e}$ & $0.8 \mathrm{e}$ & $1.4 \mathrm{e}$ & 4.0 & 3.3 & 5.0 & 3.4 & $1.3 \mathrm{e}$ \\
\hline Netherlands & 3.1 & 3.4 & 4.3 & 3.9 & 4.7 & 3.9 & 1.9 & 0.1 & 0.3 & 2.2 & 2.0 & 3.4 & 3.6 & 2.0 \\
\hline New Zealand & 4.2 & 3.5 & 1.7 & 0.5 & 5.3 & 2.4 & 3.6 & 4.9 & 4.3 & 3.8 & 3.0 & 1.8 & 3.1 & $-1.1 \mathrm{e}$ \\
\hline Norway & 4.2 & 5.1 & 5.4 & 2.7 & 2.0 & 3.3 & 2.0 & 1.5 & 1.0 & 3.9 & 2.7 & 2.3 & 3.1 & 2.1 \\
\hline Poland & 7.0 & 6.2 & 7.1 & 5.0 & 4.5 & 4.3 & 1.2 & 1.4 & 3.9 & 5.3 & 3.6 & 6.2 & 6.8 & 5.0 \\
\hline Portugal & 4.3 & 3.6 & 4.2 & 4.9 & 3.8 & 3.9 & 2.0 & 0.8 & -0.8 & 1.5 & 0.9 & 1.4 & 1.9 & -0.0 \\
\hline Slovak Republic & 5.8 & 6.9 & 4.4 & 4.4 & 0.0 & 1.4 & 3.4 & 4.8 & 4.7 & 5.2 & 6.5 & 8.5 & 10.4 & 6.4 \\
\hline Spain & 2.8 & 2.4 & 3.9 & 4.5 & 4.7 & 5.0 & 3.6 & 2.7 & 3.1 & 3.3 & 3.6 & 4.0 & 3.6 & 0.9 \\
\hline Sweden & 4.0 & 1.5 & 2.5 & 3.8 & 4.6 & 4.4 & 1.1 & 2.4 & 1.9 & 4.1 & 3.3 & 4.2 & 2.6 & -0.2 \\
\hline Switzerland & 0.4 & 0.6 & 2.1 & 2.6 & 1.3 & 3.6 & 1.2 & 0.4 & -0.2 & 2.5 & 2.6 & 3.6 & 3.6 & 1.8 \\
\hline Turkey & $7.2 \mathrm{e}$ & $7.0 \mathrm{e}$ & $7.5 \mathrm{e}$ & 3.1 & -3.4 & 6.8 & -5.7 & 6.2 & 5.3 & 9.4 & 8.4 & 6.9 & 4.7 & 0.9 \\
\hline United Kingdom & 3.0 & 2.9 & 3.3 & 3.6 & 3.5 & 3.9 & 2.5 & 2.1 & 2.8 & 2.8 & 2.1 & 2.8 & 3.0 & 0.7 \\
\hline United States & 2.5 & 3.8 & 4.5 & 4.4 & 4.9 & 4.2 & 1.1 & 1.8 & 2.5 & 3.6 & 3.1 & 2.7 & 2.1 & 0.4 \\
\hline Euro area &.. & 1.6 & 2.6 & 2.8 & 2.9 & 3.9 & 1.9 & 0.9 & 0.8 & 2.2 & 1.7 & 3.0 & 2.8 & 0.7 \\
\hline OECD-Total & $2.5 \mathrm{e}$ & $3.1 \mathrm{e}$ & $3.6 \mathrm{e}$ & $2.7 \mathrm{e}$ & $3.5 \mathrm{e}$ & $4.2 \mathrm{e}$ & $1.3 \mathrm{e}$ & $1.7 \mathrm{e}$ & $2.0 \mathrm{e}$ & 3.2 & 2.7 & 3.1 & 2.8 & $0.6 \mathrm{e}$ \\
\hline
\end{tabular}

Figure 2.1. Gross domestic product, volume

Average annual growth rates between 1998 and 2008

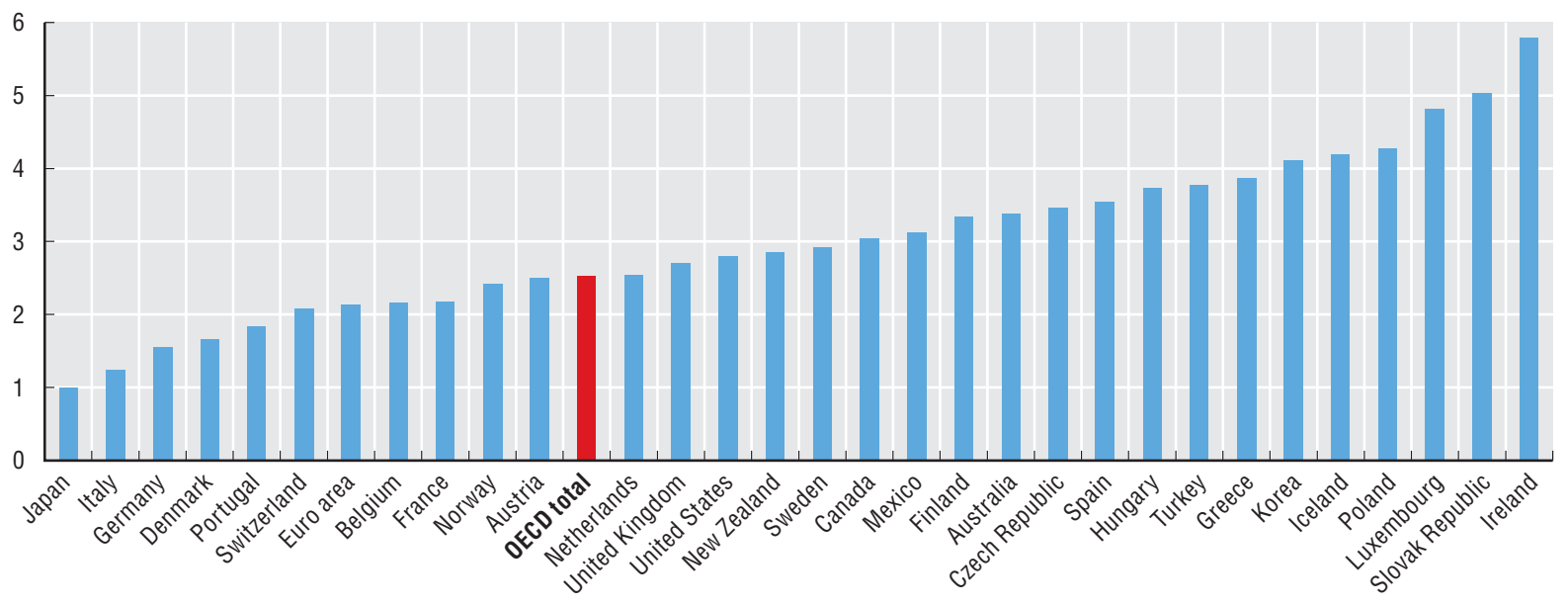

StatLink AाISL http://dx.doi.org/10.1787/738560831304 
Gross Domestic Product (GDP) per capita is a core indicator of economic performance and commonly used as a broad measure of average living standards or economic well-being; despite some recognised shortcomings.

For example average GDP per capita gives no indication of how GDP is distributed between citizens. Average GDP per capita may rise for example but more people may be worse off if income inequalities also increase.

Equally, in some countries (see Comparability on the right), there may be a significant number of nonresident border or seasonal workers or indeed inflows and outflows of property income and both phenomena imply that the value of production differs from the income of residents, thereby over or understating their living standards.

A full discussion of these issues can be found in the Stiglitz-Sen-Fitoussi report (see references).

\section{Definition}

The definition for GDP is described in section 1 and population estimates are described in the Reader Notes section.

A focus on per capita GDP is also useful in decomposing drivers of overall GDP growth. For example real GDP can grow without there being any improvement in real GDP per capita. Decomposing per capita growth into two parts, labour productivity growth (measured as GDP per hour worked) and labour utilisation growth (measured as hours worked per capita) is helpful in this context.

\section{Comparability}

Generally, particularly because all countries follow the 1993 System of National Accounts, the comparability of population and GDP estimates across countries is good (see Section 1). However, some care is needed in interpretation, for example Luxembourg and, to a lesser extent, Switzerland have a relatively large number of frontier workers. Such workers contribute to GDP but are excluded from the population figures, which is one of the reasons why cross-country comparisons of income per capita based on gross or net national income (GDI and NNI) are often preferred, see Chapter 2 on Income. (See also "Reader's Guide", relating to PPP based comparisons.)

\section{Source}

- OECD (2009), National Accounts of OECD Countries 2009, Volume I, Main Aggregates, OECD Publishing, http://dx.doi.org/10.1787/na_vol_1-2009-en-fr.

\section{Online database}

- OECD (2009), "Aggregate national accounts: gross domestic product", OECD National Accounts Statistics (database), http://dx.doi.org/10.1787/data-00001-en.

\section{Further reading}

- Report of the Commission on the Measurement of Economic Performance and Social Progress (StiglitzSen-Fitoussi Report), www.stiglitz-sen-fitoussi.fr.

- OECD (2002), Measuring the Non-Observed Economy: A Handbook, International Labour Office/International Monetary Fund/International Statistical Committee of the Commonwealth of Independent States, OECD Publishing, http://dx.doi.org/10.1787/9789264175358-en.

- Lequiller, F. and D. Blades (2007), Understanding National Accounts, OECD Publishing, http://dx.doi.org/10.1787/9789264027657-en.

- OECD (2000), System of National Accounts, 1993 Glossary, OECD Publishing, http://dx.doi.org/10.1787/9789264180871-en.

- UN, OECD, IMF, Eurostat (eds.) (1993), System of National Accounts 1993, United Nations, Geneva, http://unstats.un.org/unsd/sna1993. 
Table 3.1. Gross domestic product per capita, $\mathrm{OECD}=\mathbf{1 0 0}$

Based on current PPPs

\begin{tabular}{|c|c|c|c|c|c|c|c|c|c|c|c|c|c|c|}
\hline & 1995 & 1996 & 1997 & 1998 & 1999 & 2000 & 2001 & 2002 & 2003 & 2004 & 2005 & 2006 & 2007 & 2008 \\
\hline Australia & 110 & 109 & 109 & 111 & 113 & 111 & 112 & 114 & 116 & 115 & 114 & 113 & 114 & $115 \mathrm{e}$ \\
\hline Austria & 120 & 119 & 116 & 117 & 117 & 117 & 114 & 116 & 116 & 115 & 112 & 112 & 113 & 113 \\
\hline Belgium & 114 & 111 & 111 & 109 & 109 & 112 & 112 & 115 & 112 & 110 & 108 & 107 & 107 & 105 \\
\hline Canada & 116 & 114 & 114 & 115 & 117 & 116 & 116 & 115 & 116 & 116 & 118 & 117 & 117 & $116 \mathrm{e}$ \\
\hline Czech Republic & 65 & 67 & 64 & 63 & 62 & 61 & 64 & 65 & 67 & 68 & 68 & 70 & 73 & 73 \\
\hline Denmark & 117 & 117 & 117 & 118 & 116 & 118 & 116 & 118 & 113 & 114 & 112 & 111 & 109 & 108 \\
\hline Finland & 96 & 94 & 98 & 102 & 102 & 105 & 105 & 106 & 103 & 106 & 103 & 104 & 105 & 105 \\
\hline France & 103 & 102 & 101 & 103 & 102 & 103 & 105 & 107 & 102 & 100 & 100 & 98 & 99 & 98 \\
\hline Germany & 115 & 113 & 110 & 109 & 109 & 106 & 106 & 106 & 107 & 106 & 105 & 105 & 104 & 106 \\
\hline Greece & 75 & 74 & 75 & 74 & 74 & 75 & 79 & 83 & 85 & 85 & 83 & 84 & 86 & 86 \\
\hline Hungary & 46 & 46 & 47 & 49 & 49 & 49 & 54 & 57 & 57 & 58 & 57 & 57 & 57 & 57 \\
\hline Iceland & 118 & 118 & 121 & 125 & 124 & 118 & 120 & 119 & 115 & 119 & 118 & 112 & 110 & 108 \\
\hline Ireland & 91 & 95 & 101 & 108 & 112 & 117 & 121 & 127 & 129 & 129 & 130 & 133 & 136 & 125 \\
\hline Italy & 108 & 106 & 105 & 107 & 105 & 104 & 107 & 103 & 101 & 97 & 95 & 94 & 93 & 92 \\
\hline Japan & 115 & 115 & 113 & 108 & 105 & 104 & 103 & 103 & 102 & 103 & 102 & 102 & 102 & $101 \mathrm{e}$ \\
\hline Korea & $68 \mathrm{e}$ & $70 \mathrm{e}$ & $71 \mathrm{e}$ & $64 \mathrm{e}$ & $68 \mathrm{e}$ & 70 & 72 & 75 & 75 & 77 & 77 & 79 & 81 & 83 \\
\hline Luxembourg & 198 & 196 & 189 & 194 & 211 & 218 & 213 & 221 & 226 & 230 & 230 & 243 & 250 & 248 \\
\hline Mexico & $38 \mathrm{e}$ & $39 \mathrm{e}$ & $40 \mathrm{e}$ & $40 \mathrm{e}$ & $40 \mathrm{e}$ & $41 \mathrm{e}$ & $40 \mathrm{e}$ & $40 \mathrm{e}$ & 41 & 41 & 42 & 43 & 43 & $43 \mathrm{e}$ \\
\hline Netherlands & 110 & 110 & 112 & 115 & 116 & 120 & 122 & 123 & 118 & 117 & 118 & 118 & 119 & 123 \\
\hline New Zealand & 87 & 86 & 85 & 84 & 86 & 84 & 85 & 85 & 85 & 85 & 83 & 82 & 82 & $79 \mathrm{e}$ \\
\hline Norway & 120 & 127 & 130 & 123 & 129 & 147 & 147 & 142 & 143 & 149 & 159 & 166 & 162 & 173 \\
\hline Poland & 38 & 40 & 41 & 43 & 43 & 43 & 43 & 44 & 45 & 46 & 46 & 47 & 49 & 53 \\
\hline Portugal & 67 & 66 & 67 & 68 & 70 & 70 & 70 & 71 & 70 & 68 & 69 & 69 & 69 & 69 \\
\hline Slovak Republic & 42 & 44 & 45 & 46 & 45 & 45 & 48 & 50 & 51 & 52 & 54 & 57 & 61 & 66 \\
\hline Spain & 81 & 82 & 82 & 85 & 86 & 87 & 89 & 92 & 92 & 92 & 92 & 94 & 96 & 94 \\
\hline Sweden & 111 & 110 & 109 & 109 & 111 & 113 & 111 & 111 & 112 & 113 & 109 & 110 & 111 & 111 \\
\hline Switzerland & 136 & 133 & 132 & 133 & 130 & 129 & 127 & 128 & 124 & 122 & 119 & 122 & 125 & 128 \\
\hline Turkey & $35 \mathrm{e}$ & $36 \mathrm{e}$ & $38 \mathrm{e}$ & 38 & 35 & 36 & 32 & 32 & 31 & 34 & 36 & 38 & 39 & 40 \\
\hline United Kingdom & 100 & 102 & 104 & 105 & 105 & 106 & 109 & 111 & 111 & 112 & 110 & 109 & 108 & 107 \\
\hline United States & 140 & 141 & 141 & 142 & 144 & 143 & 142 & 141 & 142 & 142 & 143 & 142 & 141 & 140 \\
\hline Euro area & 102 & 101 & 100 & 101 & 100 & 100 & 102 & 102 & 101 & 100 & 99 & 99 & 99 & 99 \\
\hline OECD-Total & 100 & 100 & 100 & 100 & 100 & 100 & 100 & 100 & 100 & 100 & 100 & 100 & 100 & 100 \\
\hline
\end{tabular}

Figure 3.1. Gross domestic product per capita, $\mathrm{OECD}=\mathbf{1 0 0}$

Based on current PPPs, 2008

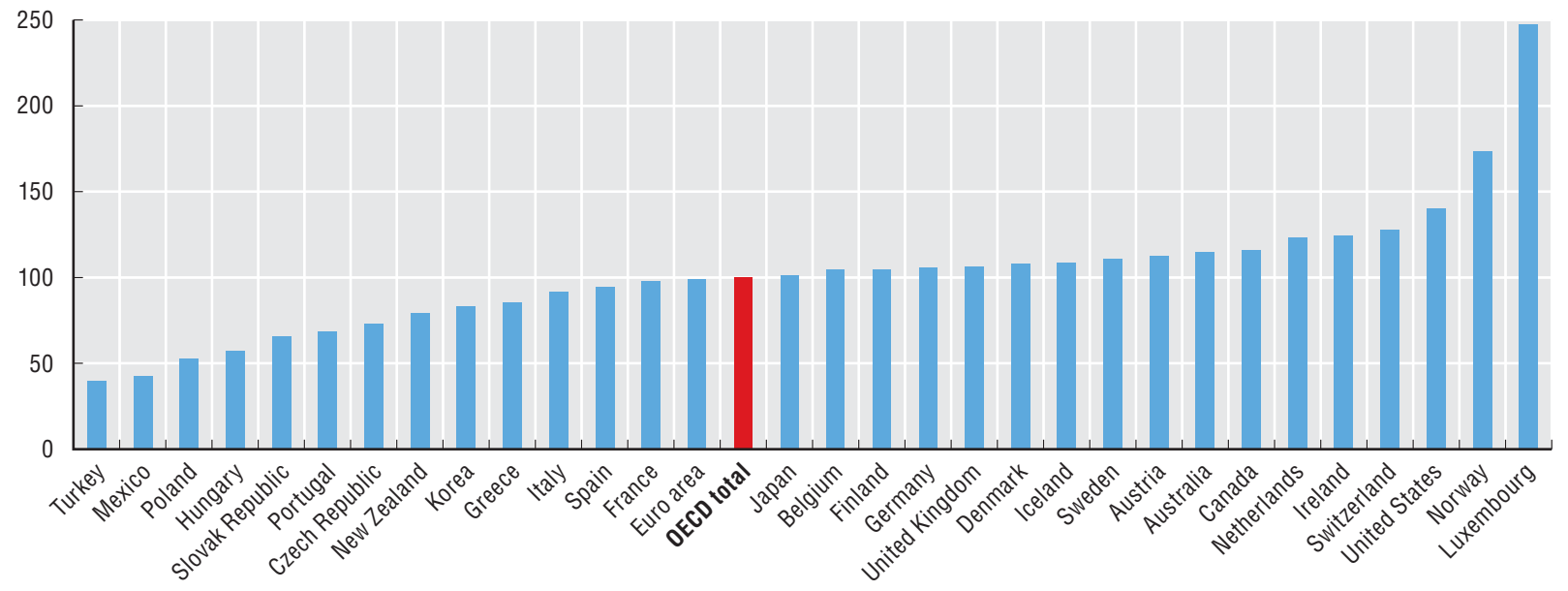

StatLink क्ञाS http://dx.doi.org/10.1787/738633261342 


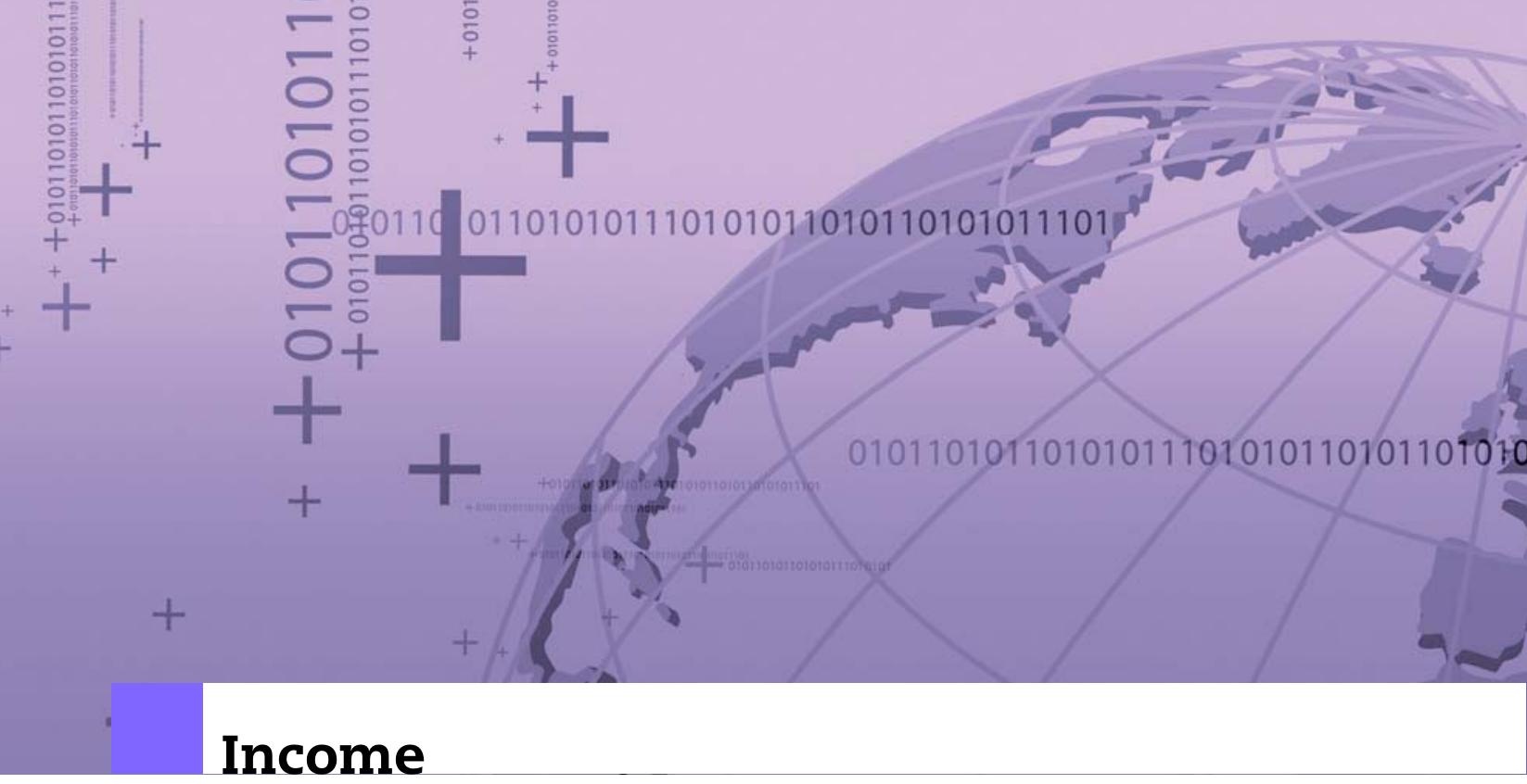

4. National income

5. Disposable income

6. Real measures of income

7. Saving

8. Household saving rate

9. Net lending/net borrowing 
While per capita gross domestic product is the indicator most commonly used to compare income levels, two other measures are preferred, at least in theory, by many analysts. These are per capita gross national income (GNI) and net national income (NNI).

\section{Definition}

GNI is defined as GDP plus net receipts from abroad of wages and salaries and of property income. NNI is equal to GNI net of depreciation.

Wages and salaries from abroad are those that are earned by residents who essentially live and consume inside the economic territory but work abroad (this happens in border areas on a regular basis) or for persons that live and work abroad for only short periods (seasonal workers) and whose centre of economic interest remains in their home country. Guest-workers and other migrant workers who live abroad for twelve months or more are considered to be resident in the country where they are working. Such persons may send part of their earnings to relatives at home, but these remittances are treated as transfers between resident and non-resident households and are recorded in national disposable income (Section 5) but not national income. Property income from abroad includes interest, dividends and all or part of the retained earnings of foreign enterprises owned fully or in part by residents. In most countries, net receipts of property income account for most of the difference between GDP and GNI.

Note that retained earnings of foreign enterprises owned by residents may not actually return to the residents concerned, and, in some countries, there are restrictions on the repatriation of profits. Receipt of retained earnings is an imputation, and, since there is no actual transaction, it is necessary to impute an outflow of the same amount. The imputed outflow is treated as a financial transaction (a reinvestment of earnings abroad) and not as an outflow of property income. Countries with large stocks of outward foreign direct investment may be shown as having large receipts of property income from abroad and therefore high GNI even though much of the property income may never actually be returned to the country but instead add to foreign direct investment.

\section{Comparability}

Both measures, GNI and NNI, are compiled according to the definitions of the 1993 System of National Accounts. There are, however, practical difficulties in the measurement both of international flows of wages and salaries and property income and of depreciation. It is for that reason that GDP per capita is the most widely used indicator of income or welfare, even though it is theoretically inferior, in that context, to either GNI or NNI.

\section{Source}

- OECD (2009), National Accounts of OECD Countries 2009, Volume I, Main Aggregates, OECD Publishing, http://dx.doi.org/10.1787/na_vol_1-2009-en-fr.

\section{Online database}

- OECD (2009), "Aggregate national accounts: Disposable income and net lending/borrowing", OECD National Accounts Statistics (database), http://dx.doi.org/10.1787/data-00002-en.

\section{Further reading}

- OECD (2010), Handbook on Deriving Capital Measures of Intellectual Property Products, OECD, Paris.

- Lequiller, F. and D. Blades (2007), Understanding National Accounts, OECD Publishing, http://dx.doi.org/10.1787/9789264027657-en.

- OECD (2000), System of National Accounts, 1993 Glossary, OECD Publishing, http://dx.doi.org/10.1787/9789264180871-en.

- UN, OECD, IMF, Eurostat (eds.) (1993), System of National Accounts 1993, United Nations, Geneva, http://unstats.un.org/unsd/sna1993. 
Table 4.1. Net national income per capita, OECD $=\mathbf{1 0 0}$

Based on current PPPs

\begin{tabular}{|c|c|c|c|c|c|c|c|c|c|c|c|c|c|c|}
\hline & 1995 & 1996 & 1997 & 1998 & 1999 & 2000 & 2001 & 2002 & 2003 & 2004 & 2005 & 2006 & 2007 & 2008 \\
\hline Australia & 103 & 102 & 102 & 104 & 106 & 104 & 106 & 108 & 110 & 108 & 106 & 105 & 106 & $107 \mathrm{e}$ \\
\hline Austria & 116 & 116 & 112 & 113 & 112 & 112 & 108 & 112 & 112 & 111 & 108 & 107 & 108 & 109 \\
\hline Belgium & 116 & 112 & 112 & 110 & 109 & 113 & 112 & 114 & 112 & 108 & 106 & 105 & 106 & 103 \\
\hline Canada & 112 & 110 & 110 & 110 & 113 & 113 & 112 & 112 & 114 & 114 & 116 & 116 & 116 & $115 \mathrm{e}$ \\
\hline Czech Republic & 60 & 61 & 58 & 57 & 55 & 54 & 56 & 57 & 59 & 59 & 61 & 62 & 64 & 64 \\
\hline Denmark & 114 & 113 & 112 & 112 & 111 & 111 & 111 & 113 & 109 & 111 & 110 & 110 & 107 & 107 \\
\hline Finland & 88 & 87 & 92 & 96 & 98 & 101 & 103 & 105 & 101 & 105 & 101 & 102 & 103 & 103 \\
\hline France & 105 & 104 & 103 & 105 & 105 & 105 & 108 & 108 & 104 & 101 & 100 & 99 & 100 & 99 \\
\hline Germany & 113 & 110 & 107 & 106 & 105 & 102 & 103 & 103 & 104 & 105 & 104 & 105 & 105 & 107 \\
\hline Greece & $79 \mathrm{e}$ & $78 \mathrm{e}$ & $78 \mathrm{e}$ & $77 \mathrm{e}$ & $76 \mathrm{e}$ & 77 & 81 & 85 & 85 & 86 & 82 & 82 & 84 & 84 \\
\hline Hungary & 42 & 41 & 41 & 43 & 43 & 44 & 48 & 52 & 53 & 53 & 52 & 52 & 51 & 52 \\
\hline Iceland & 114 & 115 & 120 & 124 & 123 & 115 & 118 & 121 & 115 & 116 & 115 & 103 & 104 & 68 \\
\hline Ireland & 85 & 89 & 93 & 99 & 98 & 102 & 104 & 107 & 113 & 113 & 113 & 117 & 120 & 110 \\
\hline Italy & 105 & 104 & 103 & 104 & 102 & 102 & 105 & 100 & 99 & 94 & 92 & 90 & 89 & 88 \\
\hline Japan & $108 \mathrm{e}$ & 109 & 106 & 101 & 98 & 97 & 96 & 96 & 95 & 95 & 95 & 94 & 95 & $96 \mathrm{e}$ \\
\hline Korea & $70 \mathrm{e}$ & $71 \mathrm{e}$ & $71 \mathrm{e}$ & $62 \mathrm{e}$ & $66 \mathrm{e}$ & 69 & 72 & 76 & 76 & 77 & 76 & 78 & 82 & 84 \\
\hline Luxembourg & 182 & 180 & 180 & 175 & 187 & 185 & 185 & 181 & 174 & 201 & 197 & 182 & 198 & 187 \\
\hline Mexico & $38 \mathrm{e}$ & $39 \mathrm{e}$ & $40 \mathrm{e}$ & $40 \mathrm{e}$ & $41 \mathrm{e}$ & $42 \mathrm{e}$ & $41 \mathrm{e}$ & $41 \mathrm{e}$ & 42 & 42 & 43 & 44 & 44 & $45 \mathrm{e}$ \\
\hline Netherlands & 111 & 110 & 112 & 111 & 116 & 121 & 121 & 122 & 118 & 119 & 116 & 119 & 120 & 119 \\
\hline New Zealand & 81 & 78 & 78 & 78 & 79 & 77 & 79 & 80 & 80 & 79 & 75 & 74 & 74 & $72 \mathrm{e}$ \\
\hline Norway & 116 & 123 & 126 & 118 & 125 & 144 & 146 & 142 & 143 & 150 & 161 & 167 & 165 & 179 \\
\hline Poland & 37 & 39 & 41 & 42 & 43 & 43 & 43 & 44 & 44 & 45 & 45 & 46 & 48 & 53 \\
\hline Portugal & 65 & 64 & 65 & 66 & 67 & 66 & 66 & 67 & 67 & 64 & 65 & 63 & 64 & 63 \\
\hline Slovak Republic & 39 & 41 & 42 & 43 & 41 & 40 & 44 & 46 & 44 & 46 & 49 & 52 & 56 & 62 \\
\hline Spain & 82 & 81 & 81 & 84 & 85 & 85 & 87 & 90 & 90 & 89 & 88 & 89 & 91 & 89 \\
\hline Sweden & 112 & 110 & 108 & 109 & 112 & 113 & 110 & 112 & 115 & 115 & 109 & 112 & 116 & 115 \\
\hline Switzerland & 135 & 132 & 134 & 135 & 133 & 133 & 127 & 126 & 128 & 126 & 125 & 126 & 121 & 112 \\
\hline Turkey & .. & .. & .. & .. & .. & .. & .. & .. & .. & .. & .. & .. & .. & .. \\
\hline United Kingdom & 102 & 103 & 106 & 108 & 106 & 108 & 112 & 116 & 117 & 117 & 114 & 111 & 112 & 112 \\
\hline United States & 145 & 145 & 145 & 148 & 149 & 149 & 147 & 145 & 146 & 147 & 147 & 147 & 144 & 143 \\
\hline Euro area & 101 & 100 & 99 & 99 & 99 & 99 & 101 & 101 & 99 & 98 & 97 & 97 & 97 & 97 \\
\hline OECD-Total & 100 & 100 & 100 & 100 & 100 & 100 & 100 & 100 & 100 & 100 & 100 & 100 & 100 & 100 \\
\hline
\end{tabular}

Figure 4.1. Net national income per capita, OECD $=100$

Current PPPs, 2008

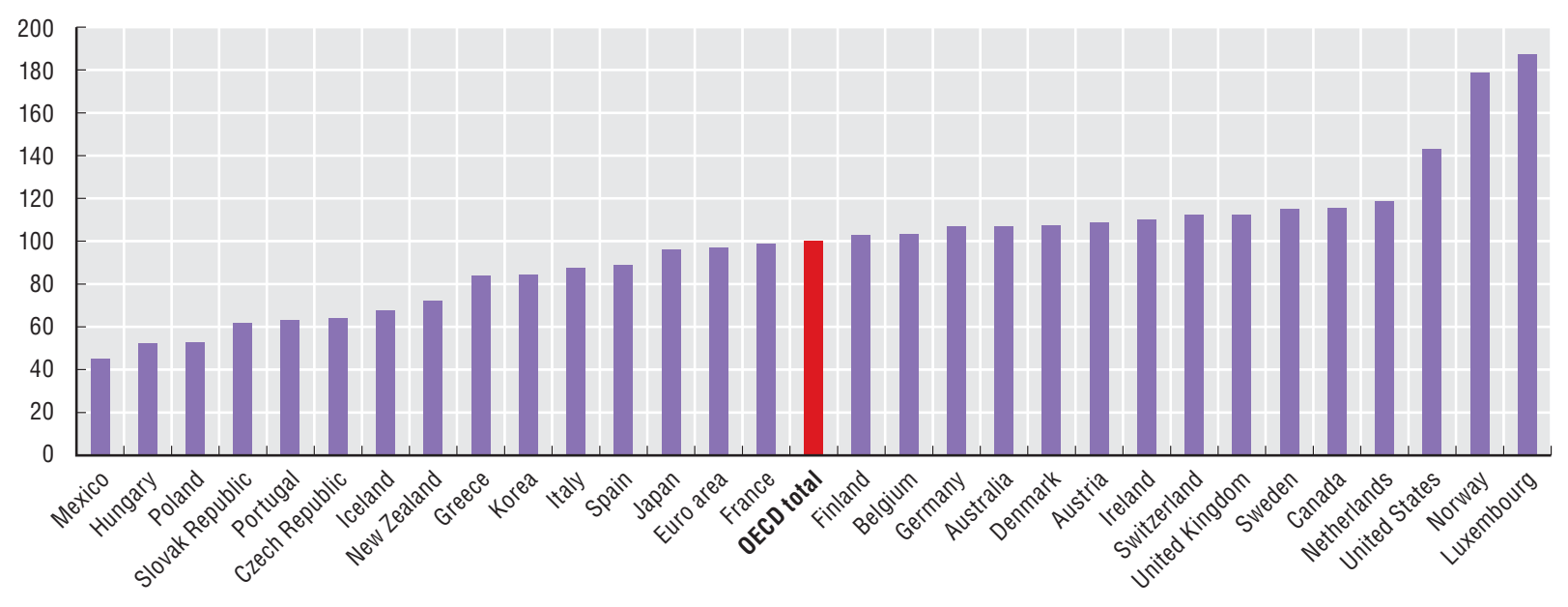

StatLink काISL http://dx.doi.org/10.1787/738651650486 
Disposable income, as a concept, is closer to the concept of income generally understood in economics, than either national income or GDP. At the total economy level it differs from national income in that additional income items are included, mainly other current transfers such as remittances. For countries where these additional items form significant sources of income the importance of focusing on disposable income in formulating policy is clear. For OECD countries the differences between national and disposable income at the total economy level are typically insignificant. But another very important difference between national income and disposable income concerns the allocation of income across sectors. At this level significant differences arise. In the main these reflect the reallocation of national income: from corporations and households to government, on account of income taxes; from households to government to reflect social contributions; and, from go-vernment and corporations to households to reflect social benefits other than social transfers in kind. It is mainly this reallocation of income that brings the concept of income closer to the economic concept. Indeed, ignoring, for simplicity, changes in net worth that arise from capital transfers or holding gains say, disposable income can be seen as the maximum amount that a unit can afford to spend on consumption goods or services without having to reduce its financial or nonfinancial assets or by increasing its liabilities.

\section{Definition}

The description given above relates to what is known as disposable income, which can be shown gross or net of depreciation. However there is an important variant of this concept, described as adjusted disposable income, which additionally reallocates "income" from government and NPISHs to households to reflect social transfers in kind. These transfers reflect expenditures made by government or NPISHs on individual goods and services, such as health and education, on behalf of an individual household.

This variant provides an important mechanism for international comparisons of households' "income" as it adjusts for the levels of individual goods and services indirectly "consumed" by households via taxation for example. The adjustment in effect imputes these expenditures from government/NPISHs to households (actual consumption) and also imputes the same values to households as if they were income, (meaning that net saving is unaffected by this reallocation, see
Section 7). In theory some social transfers in kind may involve non-resident households or governments/ NPISH but these are typically insignificant and, so, the SNA recommends, unless strong evidence to the contrary exists, that these cross border flows net out.

\section{Comparability}

Both measures are compiled according to the definitions of the 1993 System of National Accounts. There are, however, practical difficulties in the measurement of the additional income components, such as remittances, that make up the difference between GDP and disposable income (including adjusted). It is for that reason that GDP per capita is the most widely used indicator of income or welfare, even though it is theoretically inferior, in that context, to measures of disposable income.

Both measures of disposable income include the payments of pension contributions to pension schemes and to social security and the receipts of pensions from pension schemes and social security. The SNA prescribes this treatment as it aligns better with the individual's concept of income and comes despite the fact that payments of pension contributions into the schemes and the receipts of pensions by pensioners constitute the acquisition and disposal of financial assets (see also Section 7). Not all countries however include these particular flows into and out of pension schemes as parts of disposable income and so comparability at the sectoral level is affected, albeit only marginally. The following countries do not adjust for these flows in the way prescribed in the SNA: Australia, Canada, France, and USA.

\section{Source}

- OECD (2009), National Accounts of OECD Countries 2009, Volume II, Detailed Tables, OECD Publishing, http://dx.doi.org/10.1787/na_vol_2-2009-en-fr.

\section{Online database}

- OECD (2009), "Detailed national accounts: nonfinancial accounts by sectors", OECD National Accounts Statistics (database), http://dx.doi.org/10.1787/data-00034-en.

\section{Further reading}

- Lequiller, F. and D. Blades (2007), Understanding National Accounts, OECD Publishing, http://dx.doi.org/10.1787/9789264027657-en.

- OECD (2000), System of National Accounts, 1993 Glossary, OECD Publishing, http://dx.doi.org/10.1787/9789264180871-en.

- UN, OECD, IMF, Eurostat (eds.) (1993), System of National Accounts 1993, United Nations, Geneva, http://unstats.un.org/unsd/sna1993. 
Table 5.1. Household gross adjusted disposable income per capita

US dollars at current PPPs

\begin{tabular}{|c|c|c|c|c|c|c|c|c|c|c|c|c|c|c|}
\hline & 1995 & 1996 & 1997 & 1998 & 1999 & 2000 & 2001 & 2002 & 2003 & 2004 & 2005 & 2006 & 2007 & 2008 \\
\hline Australia &.. & & .. & .. & .. & .. & .. & .. & .. & .. & .. & .. & .. & .. \\
\hline Austria & 18099 & 18506 & 18519 & 19258 & 20181 & 22121 & 22037 & 23492 & 24102 & 25296 & 24999 & 26926 & 28314 & 29733 \\
\hline Belgium & 17931 & 18133 & 18498 & 18681 & 19351 & 21814 & 22724 & 24255 & 23588 & 24356 & 23765 & 25381 & 26649 & 27833 \\
\hline Canada & .. & .. & .. & .. & .. & .. & .. & .. & .. & .. & .. & .. & .. & .. \\
\hline Czech Republic & 9420 & 9953 & 10286 & 10130 & 10493 & 11221 & 12017 & 12628 & 13193 & 13789 & 12984 & 15126 & 16457 & 17323 \\
\hline Denmark & 15722 & 16284 & 16700 & 17550 & 17530 & 18662 & 19066 & 20630 & 20121 & 21165 & 21711 & 22440 & 23190 & 24027 \\
\hline Finland & 12756 & 13000 & 13867 & 14432 & 15340 & 16733 & 17343 & 18834 & 19171 & 20655 & 21570 & 22060 & 23375 & 24603 \\
\hline France & 16807 & 17254 & 17887 & 18554 & 19272 & 21401 & 22843 & 24872 & 23954 & 24923 & 24341 & 26281 & 27719 & 28819 \\
\hline Germany & 18411 & 18999 & 19227 & 19480 & 20315 & 21581 & 22427 & 23451 & 24162 & 24923 & 25344 & 26997 & 27730 & 28985 \\
\hline Greece &.. & & .. &.. & & .. &.. & & .. & .. & .. & .. & .. & .. \\
\hline Hungary & 8238 & 8256 & 8473 & 8838 & 9123 & 9875 & 10717 & 12022 & 12324 & 13023 & 12374 & 14002 & 13959 & 14133 \\
\hline Iceland &.. & & .. &.. & .. & .. & .. & .. & .. & .. & .. & .. & .. & .. \\
\hline Ireland & .. & &.. & .. & .. & .. & .. & 17411 & 17975 & 19353 & 19944 & 20794 & 21904 & 26253 \\
\hline Italy & 17151 & 17698 & 18089 & 18486 & 18894 & 20312 & 22085 & 22079 & 22115 & 22381 & 22862 & 23646 & 24369 & 25007 \\
\hline Japan & .. & 16856 & 17161 & 17278 & 17574 & 18556 & 18656 & 19794 & 20339 & 21238 & 22491 & 23434 & 24343 & .. \\
\hline Korea & .. & .. &.. & .. & .. & 11675 & 11960 & 12654 & 13323 & 14207 & 14749 & 15528 & 16288 & 17008 \\
\hline Luxembourg &.. & .. & .. &.. & .. &.. &.. & .. & .. & .. & .. & .. & .. & .. \\
\hline Mexico &.. & .. & .. &.. & .. &.. & .. &.. &.. &.. & .. & .. & .. & .. \\
\hline Netherlands & 15078 & 15740 & 16645 & 17503 & 18357 & 20461 & 21913 & 23475 & 22322 & 23153 & 22511 & 25085 & 26596 & .. \\
\hline New Zealand &.. & .. &. &.. & .. &.. & .. & .. & .. & .. & .. & .. &.. & .. \\
\hline Norway & 15954 & 16937 & 17702 & 18631 & 19136 & 20830 & 21269 & 23735 & 24968 & 26325 & 28655 & 27249 & 28377 & .. \\
\hline Poland & 6677 & 7138 & 7719 & 8169 & 8593 & 9277 & 9762 & 10353 & 10399 & 10969 & 10786 & 11959 & 12856 & .. \\
\hline Portugal & 10619 & 10994 & 11401 & 11768 & 12659 & 14004 & 14657 & 15422 & 15554 & 16139 & 17283 & 17876 & 18317 & 19356 \\
\hline Slovak Republic & 5768 & 7145 & 8011 & 8353 & 8232 & 8799 & 9695 & 10689 & 10415 & 10953 & 11021 & 12793 & 14315 & .. \\
\hline Spain & .. & & .. & $\cdot$ & .. & 17011 & 18027 & 19819 & 19808 & 20677 & 20707 & 22578 & 23492 & .. \\
\hline Sweden & 15284 & 15574 & 15694 & 16177 & 17235 & 19026 & 20153 & 21865 & 22113 & 22749 & 22538 & 23748 & 24957 & 26441 \\
\hline Switzerland & 18442 & 18737 & 19493 & 20007 & 20462 & 22055 & 22877 & 24153 & 23441 & 24421 & 25345 & 25887 & 27524 & .. \\
\hline Turkey &.. & & .. & .. & .. & .. & .. & .. & .. & .. & .. & .. & .. & .. \\
\hline United Kingdom & 15690 & 16751 & 17811 & 18142 & 18828 & 21038 & 22635 & 24194 & 24564 & 25848 & 25501 & 27259 & 28052 & 29520 \\
\hline United States & .. & & .. & .. & .. &.. & .. & .. & .. & .. &.. & .. & .. & .. \\
\hline Euro area & .. &.. & .. & .. &.. &. & .. & .. & .. & .. & .. & .. & .. & .. \\
\hline OECD-Total & .. & .. & .. & .. & .. & .. & .. & .. & .. & .. & .. & .. & .. & .. \\
\hline
\end{tabular}

Figure 5.1. Disposable income - gross and gross adjusted - by sector Total economy $=100 \%$, 2007

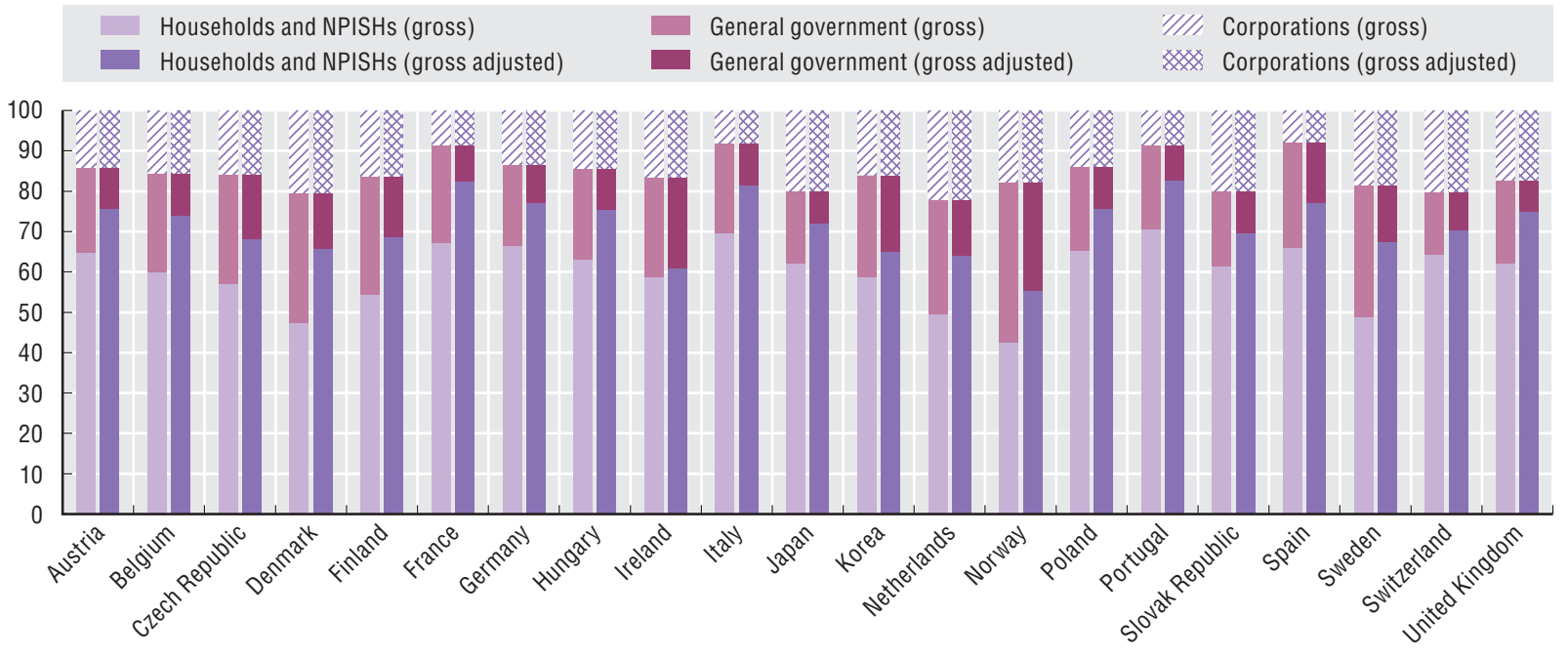

StatLink AाIS http://dx.doi.org/10.1787/738656053608 
As described in earlier sections, measures of income, such as national or disposable income are generally preferred, in theory, to GDP, in analyses of well-being both in nominal and real terms. However there are some specificities related to the calculation and associated interpretations of real income, as opposed to real GDP say, that are worth mentioning.

\section{Definition}

Whereas GDP can be measured relatively simply in volume terms because price and quantity components exist, at least in principle, for all of the flows in GDP (via the expenditure or production approach), this is not the case for the additional income components that reflect the difference between GNI say and GDP; which cannot be decomposed into price and quantity dimensions. These flows can be measured in "real" terms through the use of an appropriate price index that measures their real purchasing power in relation to a selected basket of goods and services. But moving from real GDP to real GNI is not simply a case of choosing an appropriate price index to deflate the additional income components. Another adjustment that takes account of changes in the terms of trade is needed; which is only relevant for real measures.

Gross Domestic Income (GDI), as opposed to Gross National Income, in current prices is exactly equal to GDP. But if the prices of a country's exports rise faster (or fall more slowly) than the prices of its imports (that is, if its terms of trade improve) fewer exports are needed to pay for a given volume of imports. Thus, an improvement in the terms of trade makes it possible for an increased volume of goods and services to be purchased by residents out of the incomes generated by a given level of domestic production. This improvement (or otherwise, e.g. if the prices of imports rise faster than exports), known as trading gains and losses from changes in the terms of trade, reflects the difference between real GDI and real GDP. It follows that it also forms part of the difference between real GDP and real national income (GNI and NNI) and disposable (and adjusted disposable) income.

These trading gains or losses are equal to the current trade balance deflated by a single price index, minus real exports, plus real imports (where estimates of real exports and real imports are consistent with those used in real GDP). And so real GDI is equal to final consumption (households, NPISH and general government final consumption) + real gross capital formation + the "real" trade balance.

\section{Comparability}

The comparability of current price measures of income is described in the previous sections. The choice of the single price index used to deflate the current trade balance varies across countries. The SNA recommends that the choice of the price index is left to statistical authorities to decide on the basis of national circumstances. Three approaches are commonly used. The first is to use either the overall import (or export) price index. The second is to use a weighted average of the overall import and export price indices. The third method, which is the approach used by many countries for simplicity, is a general price index (typically this is the implied deflator for gross domestic final expenditure). The advantage of this third approach is that the income components that reflect the difference between GNI (and other income measures) and GDP can also be (and usually are) meaningfully deflated using this same general price index.

\section{Source}

- OECD (2009), National Accounts of OECD Countries 2009, Volume I, Main Aggregates, OECD Publishing, $h t t p: / / d x . d o i . o r g / 10.1787 / n a \_v o l \_1-2009-e n-f r$.

\section{Online database}

- OECD (2009), “Aggregate national accounts: disposable income and net lending/borrowing", OECD National Accounts Statistics (database), http://dx.doi.org/10.1787/data-00002-en.

\section{Further reading}

- Eurostat (2001), Handbook on Price and Volume Measures in National Accounts, Eurostat, Luxembourg.

- Lequiller, F. and D. Blades (2007), Understanding National Accounts, OECD Publishing, http://dx.doi.org/10.1787/9789264027657-en.

- OECD (2000), System of National Accounts, 1993 Glossary, OECD Publishing, http://dx.doi.org/10.1787/9789264180871-en.

- UN, OECD, IMF, Eurostat (eds.) (1993), System of National Accounts 1993, United Nations, Geneva, http://unstats.un.org/unsd/sna1993. 
Table 6.1. Real net national income index

Year $2000=100$

\begin{tabular}{|c|c|c|c|c|c|c|c|c|c|c|c|c|c|c|}
\hline & 1995 & 1996 & 1997 & 1998 & 1999 & 2000 & 2001 & 2002 & 2003 & 2004 & 2005 & 2006 & 2007 & 2008 \\
\hline Australia & 80 & 85 & 89 & 93 & 97 & 100 & 104 & 108 & 115 & 119 & 124 & 129 & 135 & $142 \mathrm{e}$ \\
\hline Austria & 89 & 91 & 92 & 95 & 97 & 100 & 100 & 103 & 104 & 107 & 109 & 112 & 114 & 116 \\
\hline Belgium & 90 & 90 & 93 & 95 & 97 & 100 & 99 & 101 & 102 & 104 & 105 & 108 & 112 & 109 \\
\hline Canada & 80 & 81 & 85 & 87 & 92 & 100 & 100 & 102 & 106 & 112 & 118 & 123 & 127 & .. \\
\hline Czech Republic & 93 & 98 & 96 & 99 & 99 & 100 & 103 & 106 & 111 & 117 & 125 & 132 & 139 & 140 \\
\hline Denmark & 87 & 90 & 93 & 95 & 97 & 100 & 101 & 102 & 103 & 108 & 113 & 118 & 117 & 117 \\
\hline Finland & 76 & 79 & 86 & 92 & 96 & 100 & 104 & 106 & 106 & 111 & 112 & 117 & 120 & 118 \\
\hline France & 86 & 88 & 90 & 94 & 97 & 100 & 102 & 102 & 103 & 106 & 107 & 109 & 112 & 111 \\
\hline Germany & 93 & 94 & 94 & 96 & 98 & 100 & 101 & 101 & 102 & 105 & 106 & 110 & 112 & 113 \\
\hline Greece & $86 \mathrm{e}$ & $88 \mathrm{e}$ & $92 \mathrm{e}$ & $95 \mathrm{e}$ & $97 \mathrm{e}$ & 100 & 105 & 109 & 114 & 119 & 120 & 125 & 130 & 131 \\
\hline Hungary & 84 & 83 & 87 & 93 & 95 & 100 & 106 & 113 & 119 & 126 & 128 & 131 & 130 & 131 \\
\hline Iceland & 76 & 80 & 86 & 94 & 97 & 100 & 103 & 107 & 107 & 112 & 122 & 120 & 130 & 83 \\
\hline Ireland & 67 & 72 & 79 & 87 & 92 & 100 & 103 & 107 & 114 & 117 & 124 & 133 & 137 & 130 \\
\hline Italy & 91 & 93 & 95 & 97 & 98 & 100 & 102 & 102 & 103 & 104 & 104 & 106 & 107 & 104 \\
\hline Japan & $97 \mathrm{e}$ & 100 & 101 & 98 & 98 & 100 & 99 & 100 & 100 & 102 & 105 & 106 & 107 & $106 \mathrm{e}$ \\
\hline Korea & $90 \mathrm{e}$ & $94 \mathrm{e}$ & $96 \mathrm{e}$ & $88 \mathrm{e}$ & $95 \mathrm{e}$ & 100 & 104 & 112 & 115 & 119 & 121 & 126 & 132 & 131 \\
\hline Luxembourg & 81 & 84 & 89 & 89 & 97 & 100 & 102 & 101 & 100 & 119 & 125 & 122 & 137 & 133 \\
\hline Mexico & $72 \mathrm{e}$ & $77 \mathrm{e}$ & $84 \mathrm{e}$ & $87 \mathrm{e}$ & $92 \mathrm{e}$ & 100 & $100 \mathrm{e}$ & $102 \mathrm{e}$ & 103 & 107 & 111 & 118 & 122 & $124 \mathrm{e}$ \\
\hline Netherlands & 81 & 83 & 88 & 89 & 95 & 100 & 101 & 101 & 102 & 105 & 105 & 112 & 114 & 111 \\
\hline New Zealand & 87 & 89 & 92 & 95 & 98 & 100 & 106 & 111 & 118 & 123 & 125 & 127 & 132 & $130 \mathrm{e}$ \\
\hline Norway & 71 & 77 & 82 & 80 & 86 & 100 & 102 & 100 & 101 & 109 & 121 & 130 & 133 & 140 \\
\hline Poland & 77 & 82 & 88 & 93 & 97 & 100 & 101 & 102 & 105 & 110 & 116 & 123 & 131 & 140 \\
\hline Portugal & 84 & 86 & 90 & 95 & 99 & 100 & 102 & 104 & 104 & 105 & 105 & 105 & .. & .. \\
\hline Slovak Republic & 86 & 89 & 95 & 99 & 97 & 100 & 103 & 108 & 107 & 115 & 125 & 136 & 150 & 160 \\
\hline Spain & 83 & 85 & 88 & 92 & 97 & 100 & 103 & 107 & 111 & 113 & 117 & 121 & 124 & 124 \\
\hline Sweden & 87 & 88 & 90 & 93 & 97 & 100 & 100 & 102 & 106 & 108 & 111 & 119 & 124 & 123 \\
\hline Switzerland & 88 & 89 & 92 & 95 & 97 & 100 & 97 & 97 & 103 & 105 & 109 & 111 & 107 & 98 \\
\hline Turkey & .. & .. & .. & .. & .. & .. &.. & .. & .. & .. & .. & .. & .. & .. \\
\hline United Kingdom & 82 & 85 & 89 & 94 & 96 & 100 & 103 & 108 & 111 & 114 & 116 & 118 & 123 & 125 \\
\hline United States & 79 & 82 & 87 & 92 & 96 & 100 & 101 & 102 & 104 & 108 & 112 & 115 & 116 & 114 \\
\hline Euro area & 88 & 90 & 92 & 95 & 98 & 100 & 102 & 103 & 104 & 107 & 108 & 111 & 114 & 112 \\
\hline OECD-Total & .. & .. & .. & .. & .. & .. & .. & .. & .. & .. & .. & .. & .. & .. \\
\hline
\end{tabular}

Figure 6.1. Real net national income

Average annual growth rates between 1998 and 2008

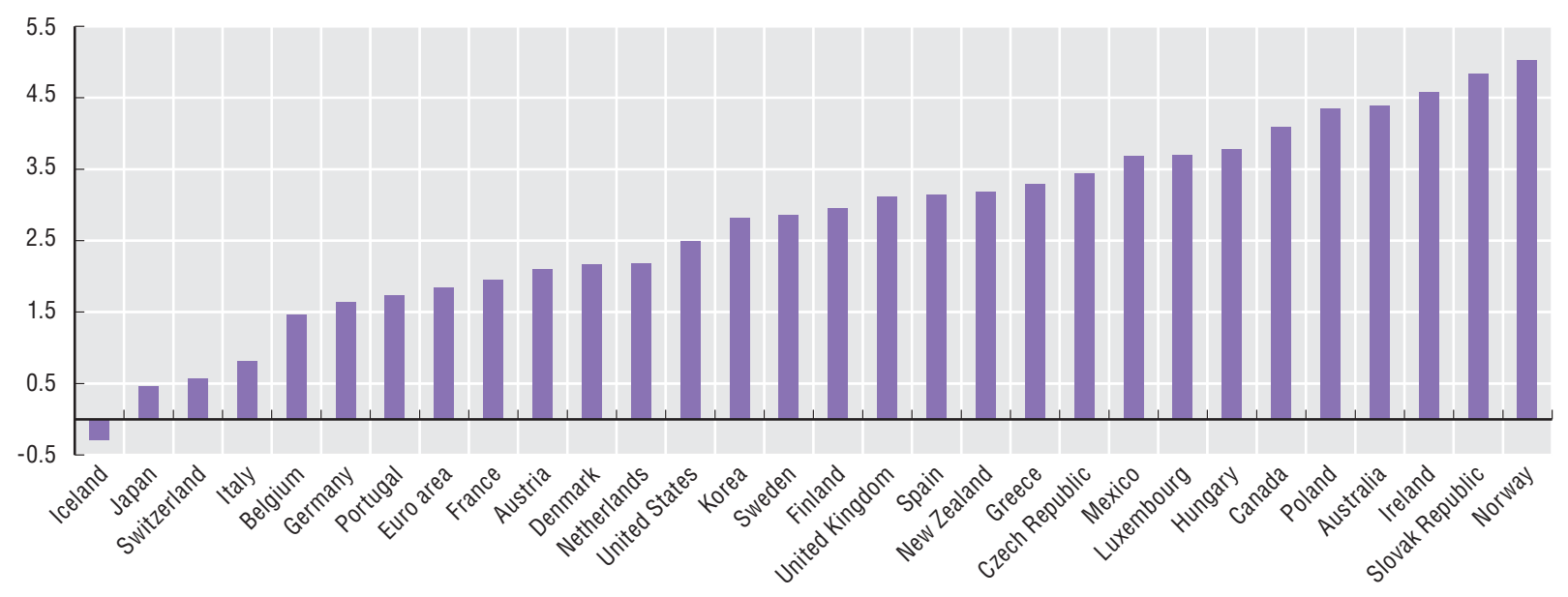

StatLink काISL http://dx.doi.org/10.1787/738668232633 
The purpose of saving is to increase future resources available for consumption and to protect against unexpected changes in income. Saving in its simplest terms is very similar to the concept of saving commonly used by the man on the street. It reflects the amount of disposable income that remains after final consumption expenditures, and that is invested - be that in financial assets, such as bank deposits or shares, or non-financial assets, such as real estate. Its importance is therefore paramount in many areas such as: analyses of the sustainability of consumption patterns; or the scope of governments to stimulate demand or raise taxes. Government saving is also an important indicator in a budgetary context. The "Golden rule", for example, that government saving should be zero over the course of an economic cycle is often set as a fiscal objective.

\section{Definition}

Saving is the difference between disposable income and final consumption expenditure plus the change in net equity of households in pension funds (since this component is also a determinant of household disposable income but with an opposite sign, see also Section 5). It can also be calculated using adjusted disposable income and actual final consumption instead of disposable income and final consumption. It therefore reflects the residual income used to acquire financial and non-financial assets. Net saving is equal to saving net of depreciation.

Because by definition they have no final consumption, saving and disposable income are exactly equal for corporations.

It's important to note that disposable income does not include any capital gains or indeed losses, and, so, neither does saving. Some have argued that disposable income and saving should include capital gains. But asset prices may rise for reasons unconnected with the productive potential of the economy, for example, a reduction of the risk premium. Moreover capital gains have to be realised before they are available to support consumption, and the very act of realising gains may actually reduce their size. Finally households respond differently to capital gains than to income. This is partly because asset prices are volatile, and partly because much household wealth is not liquid (e.g. pension funds).
An interesting point to note in this context is the treatment of capital gains taxes, which are included in disposable income. Taken to an extreme, for households this means that savings will fall, everything else being equal, during periods of strong asset prices because of the taxes payable on capital gains realized.

\section{Comparability}

Because disposable income and final consumption expenditure are large aggregates, small changes to either are capable of producing a large change in gross saving. Although in itself this does not impair international comparability it does mean that some care is needed in interpreting early estimates of saving's statistics, which may be affected by revisions.

As described in Section 5 not all countries include changes in net equity of households in pension funds and so savings estimates at the sectoral level will be affected.

Some care is also needed in terms of economic interpretability at the sectoral level. For example, because in many countries capital gains taxes are lower than marginal income taxes, instead of paying a dividend, a company may choose to buy its own equity at a premium, so rewarding its shareholders with a capital gain. This would result in lower estimates of households savings than if dividends were paid, as dividends are recorded as disposable income.

\section{Source}

- OECD (2009), National Accounts of OECD Countries 2009, Volume I, Main Aggregates, OECD Publishing, $h t t p: / / d x . d o i . o r g / 10.1787 / n a \_v o l \_1-2009-e n-f r$.

\section{Online database}

- OECD (2009), "Aggregate national accounts: disposable income and net lending/borrowing", OECD National Accounts Statistics (database), http://dx.doi.org/10.1787/data-00002-en.

\section{Further reading}

- Lequiller, F. and D. Blades (2007), Understanding National Accounts, OECD Publishing, http://dx.doi.org/10.1787/9789264027657-en.

- OECD (2000), System of National Accounts, 1993 Glossary, OECD Publishing, http://dx.doi.org/10.1787/9789264180871-en.

- UN, OECD, IMF, Eurostat (eds.) (1993), System of National Accounts 1993, United Nations, Geneva, http://unstats.un.org/unsd/sna1993. 
Household saving is the main domestic source of funds to finance capital investment, which is a major impetus for long-term economic growth. Household saving rates vary considerably between countries because of institutional, demographic and socio economic differences. For example government provisions for old-age pensions and the demographic age structure of the population will all influence the rate at which populations save (older persons tend to run down their financial assets during their retirement to the detriment of saving). Equally the availability and price of credit, as well as attitudes towards debt, may also influence choices made by individuals regarding whether to spend or save.

\section{Definition}

In the national accounts, household saving is estimated by subtracting household consumption expenditure from household disposable income plus the change in net equity of households in pension funds (since this component is also a determinant of household disposable income but with an opposite sign).

Household disposable income consists essentially of income from employment and from the operation of unincorporated enterprises, plus receipts of interest, dividends and social benefits minus payments of current taxes, interest and social contributions. Note that enterprise income includes imputed rents paid by owneroccupiers of dwellings, see also Section 5 .

Household consumption expenditure consists mainly of cash outlays for consumer goods and services but it also includes the imputed expenditures that owner occupiers pay, as occupiers, to themselves as owners of their dwellings and the production of goods for own-final use such as agricultural products - the values of which are also included in income.

The household saving rate is calculated as the ratio of household saving to household disposable income (plus the change in net equity of households in pension funds).

\section{Comparability}

Saving rates may be measured on either a net or a gross basis. Net saving rates are measured after deducting consumption of fixed capital, (in respect of assets used in unincorporated enterprises and in respect of owner-occupied dwellings), from saving and from the disposable income of households, so that both saving and disposable income are shown on a net basis.

Most countries publish ratios on a net basis. However some countries publish these ratios on a gross basis; which causes an upward bias compared to net ratios: (as saving is always less than disposable income, and depreciation is unlikely to ever be larger than disposable income)

In the data and charts that follow, households include households plus non-profit institutions serving households.

\section{Source}

- OECD (2009), National Accounts of OECD Countries 2009, Volume II, Detailed Tables, OECD Publishing, http://dx.doi.org/10.1787/na_vol_2-2009-en-fr.

\section{Online database}

- OECD (2009), "Detailed national accounts: simplified non-financial accounts", OECD National Accounts Statistics (database), http://dx.doi.org/10.1787/data-00010-en.

\section{Further reading}

- Lequiller, F. and D. Blades (2007), Understanding National Accounts, OECD Publishing, http://dx.doi.org/10.1787/9789264027657-en.

- OECD (2000), System of National Accounts, 1993 Glossary, OECD Publishing, http://dx.doi.org/10.1787/9789264180871-en.

- UN, OECD, IMF, Eurostat (eds.) (1993), System of National Accounts 1993, United Nations, Geneva, http://unstats.un.org/unsd/sna1993. 
Net lending/borrowing is one of only two balancing items in the SNA where the reference to "net" is not in juxtaposition to "gross": in other words it is not in reference to lending net of depreciation. If it is positive it is described as net lending and if negative, as net borrowing. It reflects the amount of financial assets that are available for lending or needed for borrowing to finance all expenditures - current, gross capital formation, non-produced non-financial assets, and capital transfers - in excess of disposable income. Its importance as an economic concept is best illustrated by the fact that it forms one of the two Maastricht excessive deficit criteria used by the European Commission to assess the soundness and sustainability of public finances.

\section{Definition}

Net lending or borrowing can be measured identically as the balancing item in either the capital or financial accounts.

It can therefore be derived as saving less acquisitions plus disposals of non-produced non-financial assets plus capital transfers receivable minus gross capital formation minus capital transfers payable.

Or it can be derived as the difference between net acquisition of financial assets and net incurrence of liabilities. Financial assets (and liabilities) include: Monetary gold, Special Drawing Rights, Currency and Deposits, Securities, Shares and other equity, Insurance Technical Reserves (including net equity of households in pension funds, see Sections 5, 7 and 8) and Other accounts receivable and payable (such as trade credits and advances for work in progress or to be undertaken).

Although it can be derived via either approach it is important to note that, in practice, achieving this equivalence is one of the most difficult tasks in compiling national accounts.

Another important point worth making in this context concerns contingencies. Many types of contractual financial arrangements do not give rise to unconditional requirements either to make payments or to provide other objects of value. These "contingencies" are not recorded as financial assets in the SNA. If an event occurs (and a feature of contingencies is that they may not), for example, transactions in financial assets related to the realization of the contingency, the transactions are recorded in the accounts in the usual way. A simple example of a contingency is an overdraft facility on a bank account. The existence of the facility does not of itself create a financial asset (of the bank) and liability (of the account holder). But any borrowing that subsequently occurs in relation to the facility will.

\section{Comparability}

Generally the comparability of statistics on net lending and net borrowing is good, especially for EU countries. That said, the difficulty that many countries face in reconciling the two approaches to measurement gives some indication of the care needed. Comparability, or rather the care needed when interpreting cross-country data, is perhaps a bigger issue at the sectoral level. Again, this is not fundamentally a question of conceptual differences but real differences in the types of institutions included within institutional sectors: for example in some countries hospitals are outside of the general government sector - see also Section 16.

\section{Source}

- OECD (2009), National Accounts of OECD Countries 2009, Volume II, Detailed Tables, OECD Publishing,

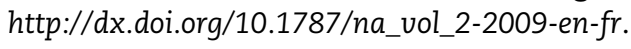

\section{Online database}

- OECD (2009), "Detailed national accounts: Simplified non-financial accounts", OECD National Accounts Statistics (database), http://dx.doi.org/10.1787/data-00010-en.

\section{Further reading}

- Eurostat (2002), ESA95 Manual on Government Deficit and Debt, European Communities, Luxembourg.

- Lequiller, F. and D. Blades (2007), Understanding National Accounts, OECD Publishing, http://dx.doi.org/10.1787/9789264027657-en.

- OECD (2000), System of National Accounts, 1993 Glossary, OECD Publishing, http://dx.doi.org/10.1787/9789264180871-en.

- UN, OECD, IMF, Eurostat (eds.) (1993), System of National Accounts 1993, United Nations, Geneva, http://unstats.un.org/unsd/sna1993. 


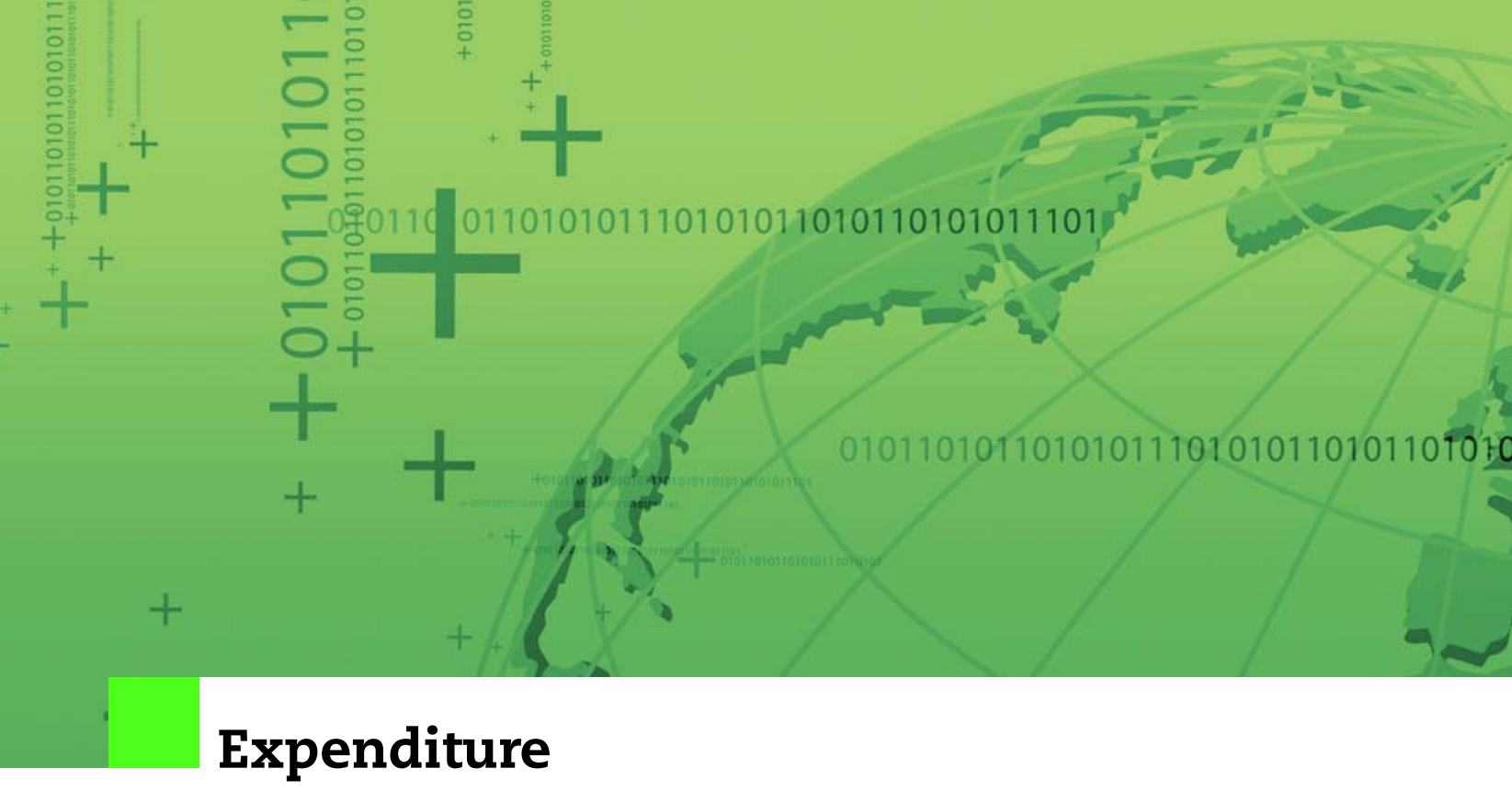

10. Household consumption

11. General government final consumption

12. Investment

13. Exports and imports of goods and services 
Household final consumption expenditure is typically the largest component of final uses of GDP, representing in ge-neral around $60 \%$ of GDP. It is therefore an essential variable for economic analysis of demand. An additional concept, (household) actual individual consumption, also exists in the SNA. This concept allocates individual consumption expenditures of general go-vernment and NPISHs (those that directly benefit households) to households (the ultimate consumers of these expenditures), providing an important measure for cross-country comparisons, in particular for comparisons of well-being.

\section{Definition}

Household final consumption expenditure covers all purchases made by resident households (home or abroad) to meet their everyday needs: food, clothing, housing services (rents), energy, transport, durable goods (notably cars), spending on health, on leisure and on miscellaneous services.

It also includes a number of imputed expenditures, for example agricultural products produced for own-consumption but the most significant imputation is typically owneroccupiers' imputed rents. The other main imputed item of expenditure relates to income in kind (employees may receive goods and services either free of charge or at very low prices as part of their wages).

By convention, apart from dwellings, all goods and services bought by households to meet their own everyday needs are recorded as final consumption. Purchases of dwellings are recorded as gross fixed capital formation. Partial payments for goods and services "provided" by general government are included in household final consumption. This covers cases in which households have to pay a part of the public services provided, for example prescription medicines and medical services partly reimbursed by government. The portion that is reimbursed forms part of expenditure by general government, and, so, also, of household actual individual consumption.

Households' actual individual consumption is equal to households' consumption expenditure plus those (individual) expenditures of general government and NPISHs that directly benefit households, such as healthcare and education. See also section 5 on disposable income.

\section{Comparability}

All countries follow the 1993 SNA and so comparability of both concepts (household final consumption and household actual individual consumption) is good. However, cross-country comparisons of actual individual consumption provide a better basis to measure relative well-being across countries. This is because there are significant differences between countries regarding the proportion of expenditure on healthcare and education paid directly by households and the proportion paid on their behalf by government, which are financed for example through taxes and that do not form part of household final consumption.

Figure 10.2 shows actual individual consumption per head using PPPs specifically related to actual individual consumption and are therefore different to those used for overall GDP.

Table 10.3 and Figure 10.3 show the contribution made by household final consumption (and other components of final demand and imports) to overall GDP growth. Note that for those countries that deflate their current price estimates of GDP using superlative price indices, such as the United States, the sum of the contribution of the individual components will not necessarily sum to the overall GDP growth rate.

\section{Source}

- OECD (2009), National Accounts of OECD Countries 2009, Volume I, Main Aggregates, OECD Publishing, http://dx.doi.org/10.1787/na_vol_1-2009-en-fr.

\section{Online database}

- OECD (2009), “Aggregate national accounts: gross domestic product", OECD National Accounts Statistics (database), http://dx.doi.org/10.1787/data-00001-en.

\section{Further reading}

- Lequiller, F. and D. Blades (2007), Understanding National Accounts, OECD Publishing, http://dx.doi.org/10.1787/9789264027657-en.

- OECD (2000), System of National Accounts, 1993 Glossary, OECD Publishing, http://dx.doi.org/10.1787/9789264180871-en.

- UN, OECD, IMF, Eurostat (eds.) (1993), System of National Accounts 1993, United Nations, Geneva, http://unstats.un.org/unsd/sna1993. 
Table 10.1. Household final and actual individual consumption

Percentage of GDP

\begin{tabular}{|c|c|c|c|c|c|c|c|c|c|c|c|c|c|c|}
\hline & \multicolumn{7}{|c|}{ Household final consumption } & \multicolumn{7}{|c|}{ Actual individual consumption } \\
\hline & 2002 & 2003 & 2004 & 2005 & 2006 & 2007 & 2008 & 2002 & 2003 & 2004 & 2005 & 2006 & 2007 & 2008 \\
\hline Australia & 59.0 & 58.6 & 58.0 & 56.6 & 55.9 & 55.4 & $54.2 \mathrm{e}$ & 69.6 & 69.2 & 69.0 & 67.3 & 66.4 & 65.9 & $64.5 \mathrm{e}$ \\
\hline Austria & 54.5 & 54.8 & 54.8 & 54.9 & 54.3 & 53.1 & 52.8 & 65.6 & 66.0 & 65.9 & 66.0 & 65.0 & 63.8 & 63.6 \\
\hline Belgium & 53.5 & 53.4 & 52.7 & 52.6 & 52.4 & 52.3 & 53.5 & 67.0 & 67.3 & 66.7 & 66.6 & 66.2 & 65.9 & 67.8 \\
\hline Canada & 56.9 & 56.6 & 55.8 & 55.3 & 55.4 & 55.5 & $55.7 \mathrm{e}$ & 68.7 & 68.4 & 67.4 & 66.8 & 67.1 & 67.3 & $67.5 \mathrm{e}$ \\
\hline Czech Republic & 51.2 & 51.7 & 50.3 & 49.1 & 48.5 & 47.7 & 49.7 & 62.5 & 63.2 & 61.5 & 60.1 & 59.2 & 58.0 & 60.0 \\
\hline Denmark & 47.5 & 47.6 & 48.2 & 48.2 & 48.7 & 49.0 & 49.1 & 65.7 & 66.2 & 66.8 & 66.5 & 67.0 & 67.3 & 68.2 \\
\hline Finland & 50.1 & 51.6 & 51.4 & 51.7 & 51.4 & 50.5 & 51.7 & 63.7 & 65.7 & 65.7 & 66.3 & 65.8 & 64.7 & 66.5 \\
\hline France & 55.9 & 56.4 & 56.6 & 56.9 & 56.8 & 56.6 & 57.1 & 70.9 & 71.8 & 72.0 & 72.3 & 72.0 & 71.7 & 72.3 \\
\hline Germany & 59.0 & 59.4 & 58.9 & 59.1 & 58.3 & 56.6 & 56.5 & 70.1 & 70.6 & 69.8 & 70.1 & 69.2 & 67.3 & 67.2 \\
\hline Greece & 72.9 & 70.7 & 70.0 & 71.9 & 72.6 & 71.9 & 72.5 & 79.0 & 77.1 & 76.3 & 78.9 & 79.6 & 79.0 & 79.6 \\
\hline Hungary & 54.3 & 56.0 & 54.6 & 55.4 & 53.9 & 53.7 & 54.0 & 65.9 & 68.8 & 66.9 & 68.0 & 66.5 & 65.2 & 65.7 \\
\hline Iceland & 54.9 & 57.2 & 57.1 & 59.5 & 58.4 & 58.0 & 54.2 & 71.7 & 74.8 & 74.1 & 76.0 & 74.8 & 74.5 & 70.8 \\
\hline Ireland & 46.8 & 46.7 & 46.1 & 46.0 & 46.0 & 46.8 & 50.1 & 56.4 & 56.5 & 56.2 & 55.8 & 55.9 & 57.1 & 61.2 \\
\hline Italy & 58.7 & 59.1 & 58.6 & 59.0 & 59.1 & 58.8 & 59.1 & 70.0 & 70.5 & 70.1 & 70.9 & 71.0 & 70.4 & 71.1 \\
\hline Japan & 57.6 & 57.5 & 57.1 & 57.0 & 57.1 & 56.3 & $57.8 \mathrm{e}$ & 67.7 & 67.5 & 67.1 & 67.1 & 67.1 & 66.4 & $68.1 \mathrm{e}$ \\
\hline Korea & 56.7 & 54.8 & 52.6 & 53.8 & 54.5 & 54.4 & 54.5 & 61.9 & 60.2 & 58.2 & 59.6 & 60.7 & 60.6 & 61.0 \\
\hline Luxembourg & 41.9 & 37.7 & 37.1 & 35.5 & 33.0 & 31.6 & 32.4 & 51.6 & 47.4 & 47.4 & 45.5 & 42.4 & 40.7 & 41.6 \\
\hline Mexico & $67.1 \mathrm{e}$ & 66.7 & 66.3 & 66.6 & 64.9 & 65.4 & $65.7 \mathrm{e}$ & $73.2 \mathrm{e}$ & 72.5 & 71.6 & 72.0 & 70.1 & 70.6 & $71.0 \mathrm{e}$ \\
\hline Netherlands & 50.1 & 49.9 & 49.4 & 48.8 & 47.2 & 46.3 & 45.7 & 63.2 & 63.5 & 62.9 & 62.1 & 62.0 & 61.4 & 60.8 \\
\hline New Zealand & 58.7 & 58.8 & 58.4 & 59.1 & 59.4 & 58.3 & $58.8 \mathrm{e}$ & 69.0 & 69.1 & 68.9 & 70.0 & 70.5 & 69.6 & $70.2 \mathrm{e}$ \\
\hline Norway & 45.6 & 46.4 & 45.1 & 42.5 & 40.8 & 41.4 & 38.9 & 59.3 & 60.6 & 58.8 & 55.5 & 53.4 & 54.4 & 51.9 \\
\hline Poland & 67.0 & 65.8 & 64.7 & 63.4 & 62.5 & 60.5 & 61.7 & 77.2 & 76.2 & 74.6 & 73.5 & 72.7 & 70.5 & 72.2 \\
\hline Portugal & 63.0 & 63.4 & 64.1 & 64.8 & 65.4 & 65.0 & 66.6 & 75.2 & 75.7 & 76.6 & 77.7 & 77.9 & 76.8 & 78.7 \\
\hline Slovak Republic & 57.6 & 56.6 & 57.1 & 57.2 & 56.8 & 55.9 & 56.5 & 66.4 & 64.8 & 64.6 & 64.7 & 64.4 & 63.6 & 64.4 \\
\hline Spain & 58.3 & 57.6 & 57.9 & 57.8 & 57.4 & 57.4 & 57.2 & 68.2 & 67.6 & 68.2 & 68.3 & 67.9 & 68.1 & 68.6 \\
\hline Sweden & 49.2 & 49.1 & 48.7 & 48.6 & 47.3 & 46.7 & 46.5 & 68.7 & 68.9 & 68.0 & 67.8 & 66.4 & 65.6 & 65.8 \\
\hline Switzerland & 60.4 & 60.7 & 60.3 & 60.0 & 58.4 & 57.0 & 57.0 & 66.8 & 67.5 & 66.9 & 66.6 & 64.7 & 63.1 & $63.0 \mathrm{e}$ \\
\hline Turkey & 68.0 & 71.2 & 71.3 & 71.7 & 70.5 & 71.3 & 69.8 & $72.6 \mathrm{e}$ & $75.6 \mathrm{e}$ & $75.5 \mathrm{e}$ & $75.9 \mathrm{e}$ & $74.9 \mathrm{e}$ & $75.8 \mathrm{e}$ & $74.3 \mathrm{e}$ \\
\hline United Kingdom & 65.8 & 65.1 & 64.7 & 64.7 & 64.1 & 63.9 & 64.4 & 77.9 & 77.8 & 77.1 & 77.5 & 77.2 & 76.9 & 77.8 \\
\hline United States & 70.2 & 70.4 & 70.1 & 70.1 & 69.9 & 70.1 & 70.5 & $76.5 \mathrm{e}$ & $76.8 \mathrm{e}$ & $76.4 \mathrm{e}$ & $76.4 \mathrm{e}$ & $76.2 \mathrm{e}$ & $76.5 \mathrm{e}$ & $77.2 \mathrm{e}$ \\
\hline Euro area & 57.2 & 57.4 & 57.2 & 57.4 & 57.0 & 56.3 & 56.5 & $69.3 \mathrm{e}$ & $69.7 \mathrm{e}$ & $69.4 \mathrm{e}$ & $69.6 \mathrm{e}$ & $69.1 \mathrm{e}$ & $68.2 \mathrm{e}$ & $68.8 \mathrm{e}$ \\
\hline OECD-Total & $62.9 \mathrm{e}$ & 63.0 & 62.7 & 62.7 & 62.4 & 62.1 & $62.5 \mathrm{e}$ & $73.9 \mathrm{e}$ & $73.5 \mathrm{e}$ & $73.1 \mathrm{e}$ & $72.0 \mathrm{e}$ & $72.2 \mathrm{e}$ & $72.0 \mathrm{e}$ & $73.1 \mathrm{e}$ \\
\hline
\end{tabular}

StatLink Nilst http://dx.doi.org/10.1787/740683805048

Figure 10.1. Household final and actual individual consumption

Percentage of GDP, 2008

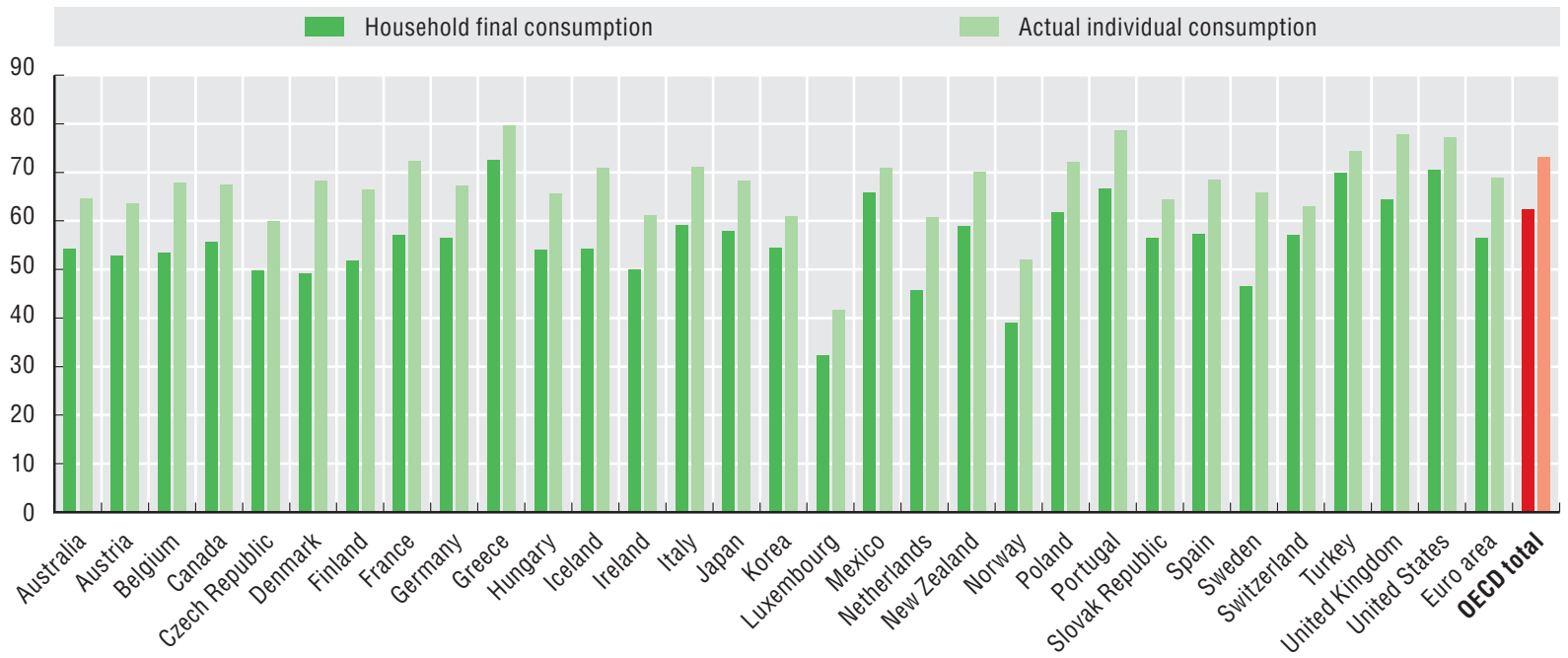

StatLink काISL http://dx.doi.org/10.1787/738734130673 
Table 10.2. Household final consumption, volume

Annual growth rates in percentage

\begin{tabular}{|c|c|c|c|c|c|c|c|c|c|c|c|c|c|c|}
\hline & 1995 & 1996 & 1997 & 1998 & 1999 & 2000 & 2001 & 2002 & 2003 & 2004 & 2005 & 2006 & 2007 & 2008 \\
\hline Australia & 3.6 & 2.5 & 4.6 & 5.0 & 4.4 & 3.6 & 3.0 & 3.4 & 5.4 & 4.4 & 2.6 & 4.1 & 3.7 & $2.6 \mathrm{e}$ \\
\hline Austria & 0.7 & 2.9 & -0.1 & 2.1 & 1.9 & 2.8 & 1.1 & 1.2 & 1.0 & 2.2 & 2.1 & 1.8 & 0.8 & 0.8 \\
\hline Belgium & 1.6 & 1.3 & 1.8 & 2.7 & 2.1 & 3.8 & 1.1 & 0.8 & 0.9 & 1.4 & 1.2 & 2.1 & 2.1 & 0.9 \\
\hline Canada & 2.1 & 2.6 & 4.6 & 2.8 & 3.8 & 4.0 & 2.3 & 3.6 & 3.0 & 3.3 & 3.7 & 4.3 & 4.5 & $3.0 \mathrm{e}$ \\
\hline Czech Republic & 5.9 & 8.4 & 2.2 & -0.8 & 2.7 & 1.3 & 2.2 & 2.2 & 6.0 & 3.0 & 2.5 & 5.2 & 5.0 & 3.6 \\
\hline Denmark & 1.6 & 2.2 & 3.0 & 2.3 & -0.4 & 0.2 & 0.1 & 1.6 & 1.0 & 4.7 & 3.8 & 4.4 & 2.4 & -0.2 \\
\hline Finland & 4.3 & 3.9 & 3.4 & 4.3 & 3.0 & 2.3 & 2.8 & 2.2 & 4.8 & 3.0 & 3.3 & 4.1 & 3.3 & 1.9 \\
\hline France & 1.7 & 1.6 & 0.4 & 3.9 & 3.5 & 3.6 & 2.6 & 2.4 & 2.0 & 2.5 & 2.6 & 2.4 & 2.5 & 1.0 \\
\hline Germany & 2.2 & 1.3 & 0.8 & 1.5 & 3.0 & 2.4 & 1.9 & -0.8 & 0.1 & 0.1 & 0.3 & 1.3 & -0.4 & 0.4 \\
\hline Greece & $2.5 \mathrm{e}$ & $2.4 \mathrm{e}$ & $2.7 \mathrm{e}$ & $3.5 \mathrm{e}$ & $2.5 \mathrm{e}$ & $2.0 \mathrm{e}$ & 5.0 & 4.7 & 3.3 & 3.6 & 4.6 & 5.3 & 3.3 & 2.3 \\
\hline Hungary & -7.3 & -3.4 & 1.6 & 4.7 & 6.3 & 4.2 & 6.5 & 10.7 & 8.4 & 3.1 & 3.2 & 1.7 & 0.4 & -0.5 \\
\hline Iceland & 2.2 & 5.7 & 6.3 & 10.2 & 7.9 & 4.2 & -2.9 & -1.5 & 6.1 & 7.0 & 12.9 & 3.9 & 5.6 & -7.7 \\
\hline Ireland & 3.5 & 7.0 & 7.7 & 7.5 & 8.9 & 10.0 & 4.8 & 3.8 & 2.9 & 3.5 & 6.6 & 6.5 & 5.6 & -0.7 \\
\hline Italy & 1.5 & 1.0 & 3.2 & 3.5 & 2.6 & 2.4 & 0.7 & 0.2 & 1.0 & 0.8 & 1.2 & 1.3 & 1.2 & -0.9 \\
\hline Japan & 1.9 & 2.5 & 0.8 & -0.9 & 1.0 & 0.7 & 1.6 & 1.1 & 0.4 & 1.6 & 1.3 & 1.5 & 0.7 & $0.6 \mathrm{e}$ \\
\hline Korea & $9.9 \mathrm{e}$ & $6.7 \mathrm{e}$ & $3.3 \mathrm{e}$ & $-13.4 \mathrm{e}$ & $11.5 \mathrm{e}$ & $8.4 \mathrm{e}$ & 5.7 & 8.9 & -0.4 & 0.3 & 4.6 & 4.7 & 5.1 & 0.9 \\
\hline Luxembourg & 1.9 & 3.0 & 3.9 & 5.7 & 3.6 & 5.0 & 3.4 & 5.8 & -5.3 & 2.2 & 2.6 & 2.7 & 2.8 & 3.9 \\
\hline Mexico & $-9.5 \mathrm{e}$ & $2.2 \mathrm{e}$ & $6.5 \mathrm{e}$ & $5.4 \mathrm{e}$ & $4.3 \mathrm{e}$ & $8.2 \mathrm{e}$ & $2.5 \mathrm{e}$ & $1.6 \mathrm{e}$ & $2.2 \mathrm{e}$ & 5.6 & 4.8 & 5.7 & 3.9 & $1.5 \mathrm{e}$ \\
\hline Netherlands & 2.7 & 4.3 & 3.5 & 5.1 & 5.3 & 3.7 & 1.8 & 0.9 & -0.2 & 1.0 & 1.0 & -0.3 & 1.8 & 1.3 \\
\hline New Zealand & 4.0 & 4.4 & 2.4 & 3.1 & 3.3 & 1.4 & 2.8 & 4.9 & 6.6 & 5.1 & 4.6 & 2.8 & 3.2 & $-0.1 \mathrm{e}$ \\
\hline Norway & 3.6 & 6.3 & 3.1 & 2.8 & 3.7 & 4.2 & 2.1 & 3.1 & 2.8 & 5.6 & 4.0 & 4.8 & 6.0 & 1.4 \\
\hline Poland & 3.2 & 8.8 & 7.2 & 5.0 & 5.7 & 3.1 & 2.2 & 3.4 & 2.1 & 4.7 & 2.1 & 5.0 & 4.9 & 5.9 \\
\hline Portugal & 0.6 & 3.2 & 3.7 & 5.0 & 5.3 & 3.7 & 1.3 & 1.3 & -0.1 & 2.5 & 2.0 & 1.9 & 1.7 & 1.7 \\
\hline Slovak Republic & 5.4 & 9.3 & 4.1 & 6.6 & 0.3 & 2.2 & 5.5 & 5.5 & 1.7 & 4.6 & 6.5 & 5.8 & 7.0 & 6.1 \\
\hline Spain & 1.7 & 2.3 & 3.2 & 4.8 & 5.3 & 5.0 & 3.4 & 2.8 & 2.9 & 4.2 & 4.2 & 3.8 & 3.6 & -0.6 \\
\hline Sweden & 1.0 & 1.7 & 2.6 & 3.0 & 4.1 & 5.1 & 0.4 & 2.6 & 2.0 & 2.6 & 2.7 & 2.3 & 3.0 & -0.3 \\
\hline Switzerland & 0.6 & 1.1 & 1.4 & 2.2 & 2.3 & 2.4 & 2.3 & 0.1 & 0.9 & 1.6 & 1.7 & 1.6 & 2.4 & 1.7 \\
\hline Turkey & $4.8 \mathrm{e}$ & $8.5 \mathrm{e}$ & $8.4 \mathrm{e}$ & 0.6 & 0.1 & 5.9 & -6.6 & 4.7 & 10.2 & 11.0 & 7.9 & 4.6 & 5.5 & -0.1 \\
\hline United Kingdom & 1.9 & 3.9 & 3.8 & 4.3 & 5.2 & 4.7 & 3.1 & 3.6 & 3.0 & 2.9 & 1.9 & 2.1 & 3.1 & 1.4 \\
\hline United States & 2.7 & 3.5 & 3.7 & 5.2 & 5.5 & 5.1 & 2.7 & 2.7 & 2.8 & 3.5 & 3.4 & 2.9 & 2.7 & -0.3 \\
\hline Euro area & .. & 1.7 & 1.7 & 3.1 & 3.4 & 3.1 & 2.0 & 0.9 & 1.2 & 1.6 & 1.9 & 2.1 & 1.6 & 0.4 \\
\hline OECD-Total & .. & $3.1 \mathrm{e}$ & $3.1 \mathrm{e}$ & $3.2 \mathrm{e}$ & $4.2 \mathrm{e}$ & $4.1 \mathrm{e}$ & $2.3 \mathrm{e}$ & $2.4 \mathrm{e}$ & $2.3 \mathrm{e}$ & 3.0 & 2.9 & 2.8 & 2.5 & $0.5 \mathrm{e}$ \\
\hline
\end{tabular}

Figure 10.2. Household final and actual individual consumption per capita, $\mathrm{OECD}=\mathbf{1 0 0}$ Current PPPs, 2008

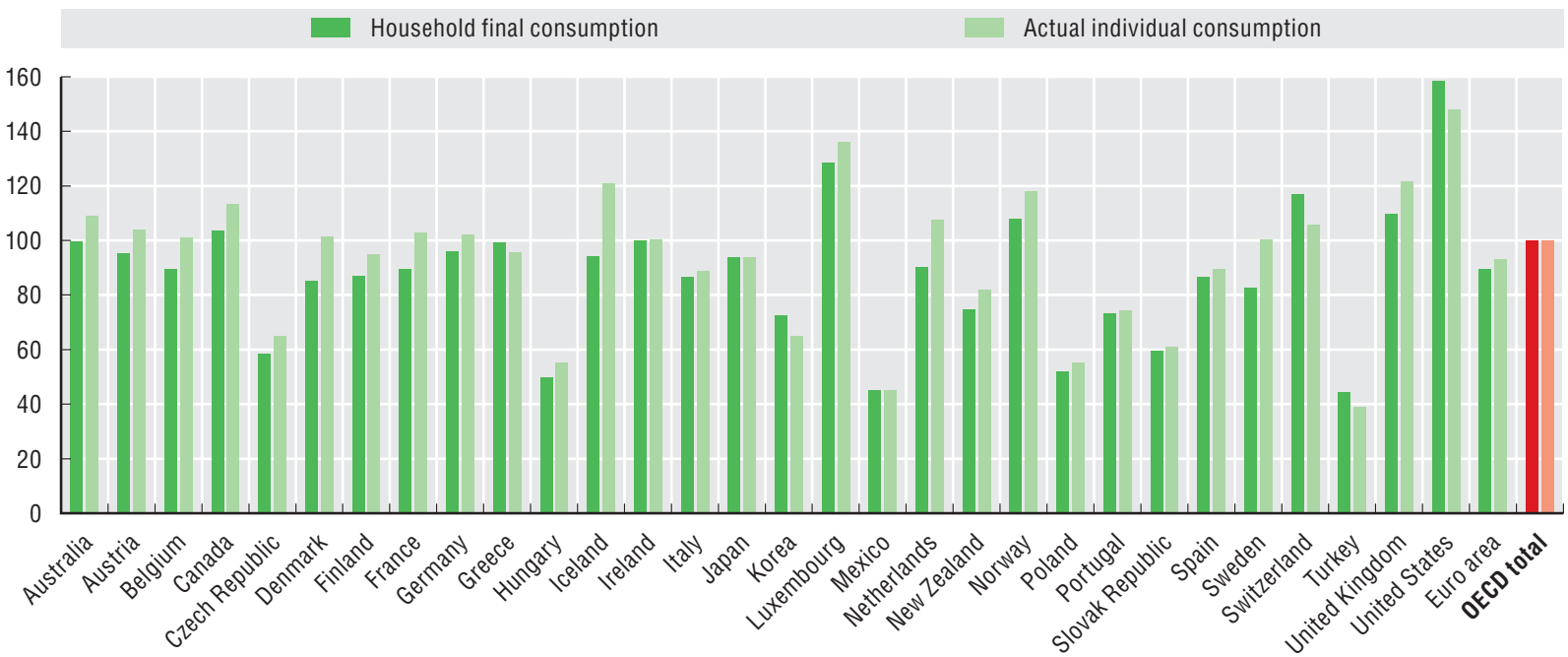

StatLink क्ञाs http://dx.doi.org/10.1787/738758540684 
Table 10.3. Contribution to GDP growth by final demand components

Percentage

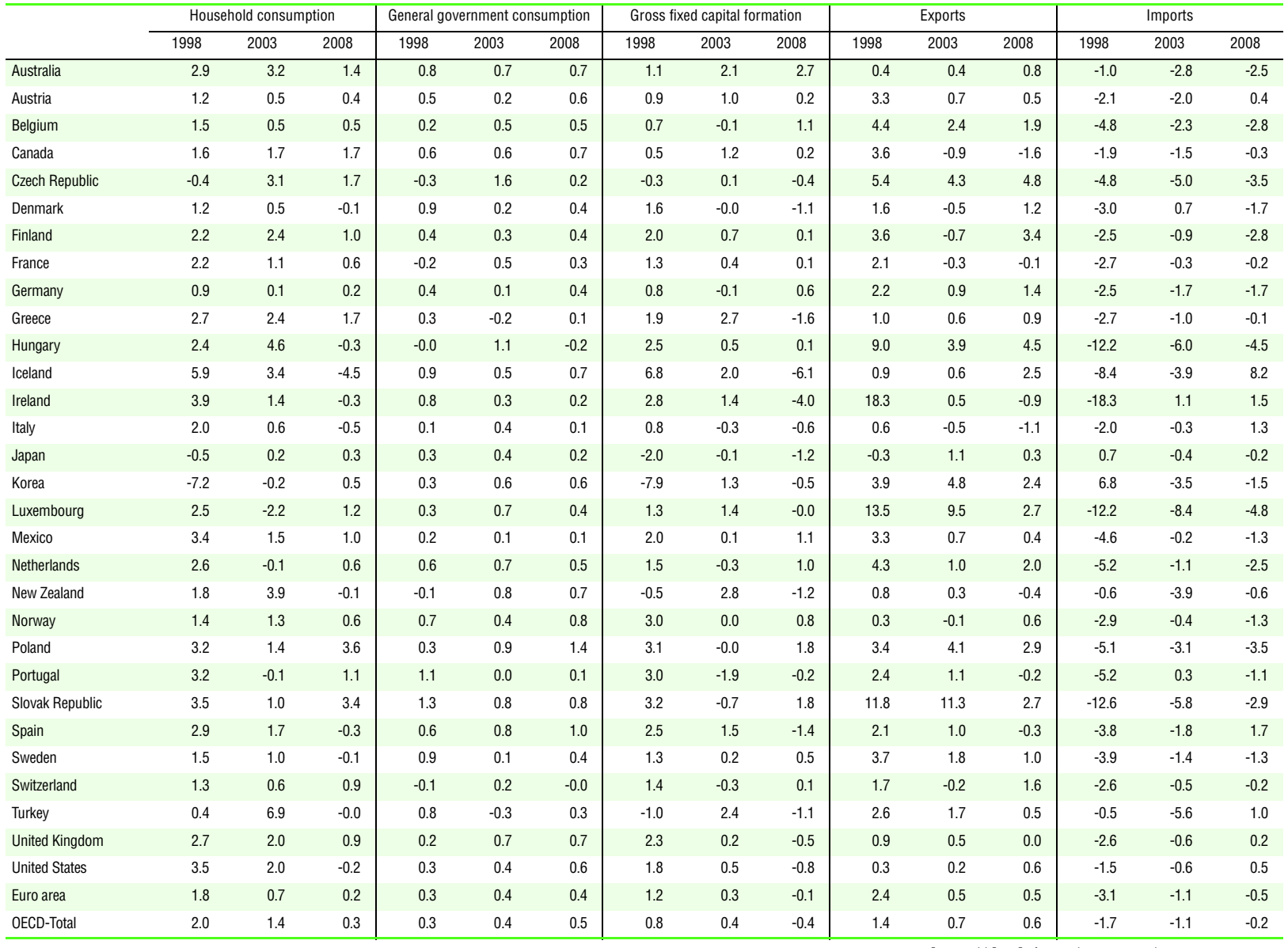

StatLink AाISL http://dx.doi.org/10.1787/740703063282

Figure 10.3. Contribution to GDP growth by final demand components

Percentage, 2008

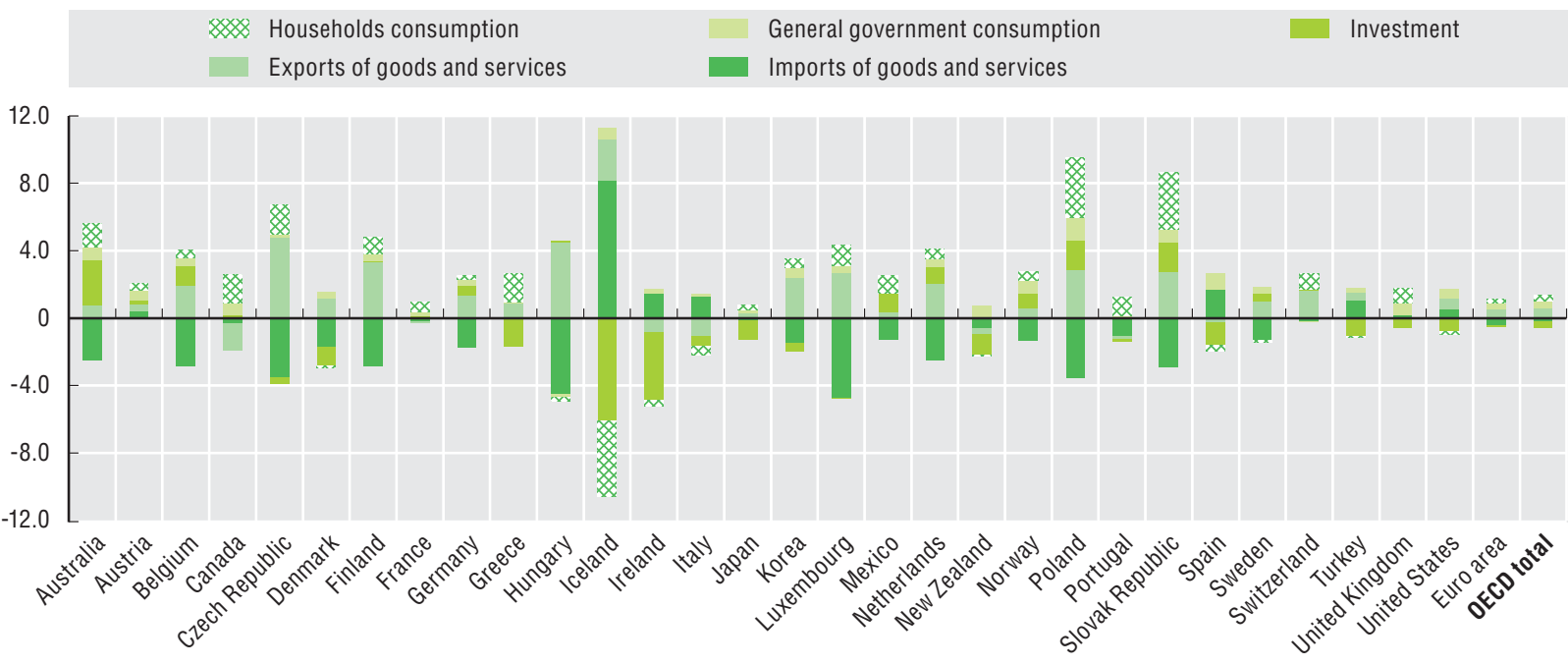

StatLink काsस http://dx.doi.org/10.1787/738801613476 
General government final consumption expenditure consists of expenditure incurred by government in its production of non-market final goods and services (except GFCF) and market goods and services provided as social transfers in kind. Total general government final consumption is perhaps of less political relevance, from a fiscal perspective, than general government expenditure (see Section 16) but its importance as a component of total GDP, and, so, as a reflection of its direct role as a "consumer" of final goods and services is significant.

\section{Definition}

General government final consumption is equal to total general government output minus market output minus own-account production of gross fixed capital formation minus depreciation plus market goods and services purchased for distribution directly to households as social transfers in kind. It can be broken down into two distinct groups.

The first reflects expenditures for collective consumption (defence, justice, etc.) which benefit society as a whole, or large parts of society, and are often known as public goods and services.

The second reflects expenditures for individual consumption (health care, housing, education, etc.), that reflect expenditures incurred by government on behalf of an individual household (see also Section 10). This category of expenditure is equal to social transfers in kind from government to households (see Section 5) and so includes expenditure by government on market goods and services provided to households.

The borderline between individual and collective consumption is in some cases not completely clear. For example, expenditures incurred by Ministries of Health and Education at a national level are included in collective services, reflecting their role as producers of policy, standards and regulation. But expenditures on the administration or functioning of a group of hospitals say are recorded as individual. To assist in this delineation the SNA provides guidance based on the Classification of the Functions of Government (COFOG). It states that all government final consumption expenditures under the following headings (Health, Recreational and sporting services, Cultural services, Education and social protection) should be treated as expenditures on individual services except for expenditures on general administration, regulation, research, etc.

\section{Comparability}

The comparability of general government final consumption across countries is high, as all countries follow the 1993 SNA. However interpretations of comparisons of general government final consumption across countries are enhanced when breakdowns between individual and collective consumption are provided (see also Section 5).

\section{Source}

- OECD (2009), National Accounts of OECD Countries 2009, Volume I, Main Aggregates, OECD Publishing, http://dx.doi.org/10.1787/na_vol_1-2009-en-fr.

\section{Online database}

- OECD (2009), "Aggregate national accounts: gross domestic product", OECD National Accounts Statistics (database), http://dx.doi.org/10.1787/data-00001-en.

\section{Further reading}

- Lequiller, F. and D. Blades (2007), Understanding National Accounts, OECD Publishing, http://dx.doi.org/10.1787/9789264027657-en.

- OECD (2000), System of National Accounts, 1993 Glossary, OECD Publishing, http://dx.doi.org/10.1787/9789264180871-en.

- UN, OECD, IMF, Eurostat (eds.) (1993), System of National Accounts 1993, United Nations, Geneva, http://unstats.un.org/unsd/sna1993. 
Table 11.1. General government final consumption expenditure Percentage of GDP

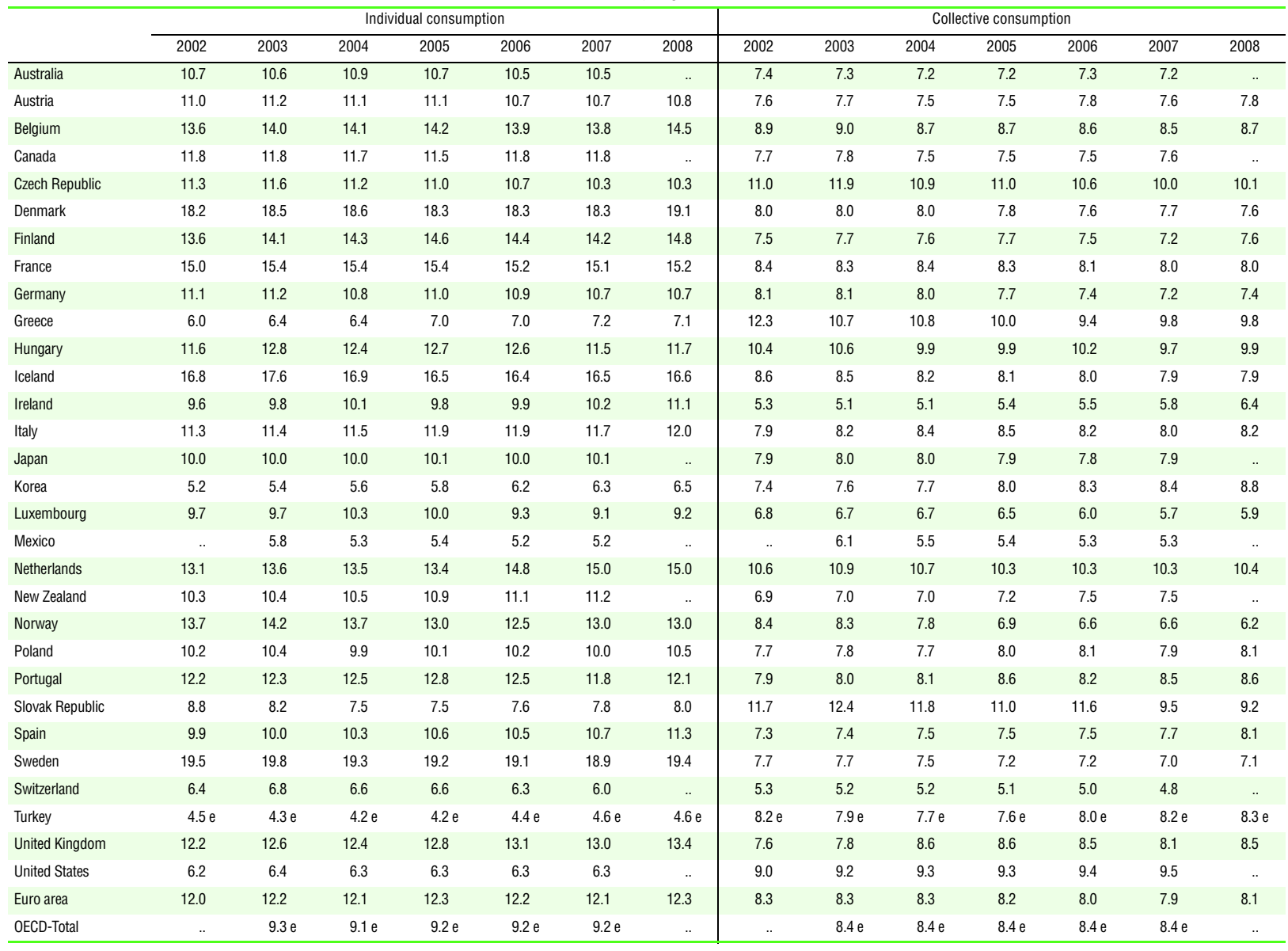

\section{Figure 11.1. General government final consumption}

Percentage of GDP, 2007

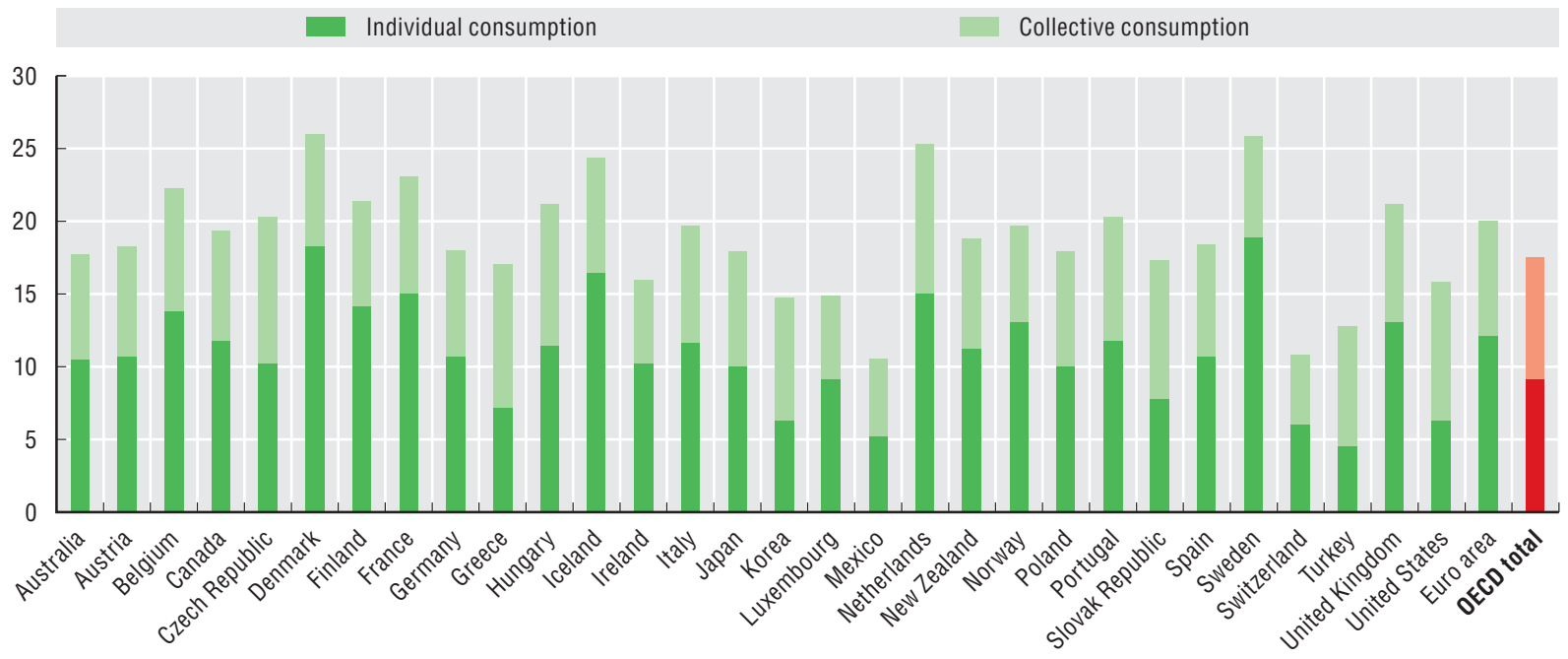

StatLink क्ञाs http://dx.doi.org/10.1787/738811605857 
Investment, or to be more precise, gross fixed capital formation is an essential variable in economic analyses, such as analyses of demand and productivity.

\section{Definition}

Gross fixed capital formation (GFCF) is defined in the national accounts as acquisition less disposals of produced fixed assets, i.e. assets intended for use in the production of other goods and services for a period of more than a year.

Acquisition includes both purchases of assets (new or second-hand) and the construction of assets by producers for their own use.

The term produced assets signifies that only those assets produced as a result of a production process recognised in the national accounts are included. The national accounts also record transactions in non-produced assets such as land, oil and mineral reserves for example; which are recorded as non-produced assets in the balance sheet accounts and not as GFCF.

Acquisition prices of capital goods include transport and installation charges, as well as all specific taxes associated with purchase.

GFCF can be broken down into particular asset groups. Table 12.2 contains 6 groups: Dwellings (excluding land); Other buildings and structures (roads, bridges, airfields, dams, etc.); Transport equipment (ships, railway, aircraft, etc.); Other machinery and equipment (office machinery and hardware, etc.); Cultivated assets (managed forests, livestock raised for milk production etc) and intellectual property type fixed assets (mineral exploration, software and databases, and literary and artistic originals, etc.).

An additional important grouping of Information and Communication Technology (ICT) products is shown in Figure 12.2. ICT has three components: information technology equipment (computers and related hardware), communications equipment and software. It's important to note that ICT embodied in non ICT assets is not included in this concept.

GFCF can also be broken down into institutional sectors. For government this typically means investment in transport infrastructure and public buildings such as schools and hospitals.

For households, GFCF generally equates to dwellings, although investments made by unincorporated enterprises in other products do occur.

\section{Comparability}

When the System of National Accounts was revised in 1993, the scope of GFCF was widened to include mineral exploration, computer software and enter- tainment, literary and artistic originals. Comparability of these items has improved in recent years but the scope with which the various items are covered is smaller in some countries, particularly in the case of own-account production of software.

In making comparisons of GFCF by institutional sector, attention should be given to the mechanisms commonly used to "acquire" assets. For example a unit may prefer to rent an asset, which will not count as GFCF of the lessee. If however the agreement between the lessee and the lessor resembles a finance lease, the SNA treats the lessee as having acquired the asset. On a larger scale many governments are increasingly turning to private finance initiatives to create public infrastructure. Determining who the owner of these schemes is in an SNA sense is non-trivial and may cause problems for temporal and international comparability.

The scope of assets has been widened in the 2008 SNA to include Research and Experimental Development and military weapons systems (see Annex for further information) but the figures contained here do not reflect these additions.

Note on Table 12.2: "Dwellings" includes "Other buildings and structure" for Norway. Cultivated assets are not capitalised for Canada and USA. "Cultivated assets" is included in "Other machinery and equipment" for United Kingdom.

\section{Source}

- OECD (2009), National Accounts of OECD Countries 2009, Volume I, Main Aggregates, OECD Publishing, http://dx.doi.org/10.1787/na_vol_1-2009-en-fr.

\section{Online databases}

- OECD (2009), “Aggregate national accounts: gross domestic product”, OECD National Accounts Statistics (database), http://dx.doi.org/10.1787/data-00001-en.

- OECD (2009), "Detailed national accounts: simplified non-financial accounts", OECD National Accounts Statistics (database),

http://dx.doi.org/10.1787/data-00010-en.

\section{Further reading}

- OECD (2010), Handbook on Deriving Capital Measures of Intellectual Property Products, OECD, Paris.

- Lequiller F., N. Ahmad, S. Varjonen, W. Cave and K.-H. Ahn (2003), Report of the OECD Task Force on Software Measurement in the National Accounts, OECD Publishing, http://dx.doi.org/10.1787/334811030426.

- Ahmad N. (2003), Measuring Investment in Software, OECD Publishing,

http://dx.doi.org/10.1787/335303788330. 
Table 12.1. Gross fixed capital formation, volume

Annual growth rates in percentage

\begin{tabular}{|c|c|c|c|c|c|c|c|c|c|c|c|c|c|c|}
\hline & 1995 & 1996 & 1997 & 1998 & 1999 & 2000 & 2001 & 2002 & 2003 & 2004 & 2005 & 2006 & 2007 & 2008 \\
\hline Australia & 2.3 & 7.7 & 9.7 & 4.5 & 8.3 & -9.5 & 9.7 & 14.4 & 8.3 & 6.2 & 8.9 & 5.5 & 9.7 & $9.6 \mathrm{e}$ \\
\hline Austria & 0.1 & 4.7 & -0.0 & 3.6 & 1.0 & 5.5 & -1.7 & -4.4 & 4.7 & 0.7 & 1.2 & 2.4 & 3.8 & 1.0 \\
\hline Belgium & 3.4 & 1.5 & 7.1 & 3.6 & 4.2 & 4.5 & 0.2 & -2.2 & -0.7 & 7.1 & 6.9 & 4.7 & 6.2 & 5.2 \\
\hline Canada & -2.1 & 4.4 & 15.2 & 2.4 & 7.3 & 4.7 & 4.0 & 1.6 & 6.2 & 7.8 & 9.2 & 7.1 & 3.9 & $0.9 \mathrm{e}$ \\
\hline Czech Republic & 19.8 & 9.9 & -5.7 & -0.9 & -3.3 & 5.1 & 6.6 & 5.1 & 0.4 & 3.9 & 1.8 & 6.0 & 10.8 & -1.5 \\
\hline Denmark & 11.9 & 5.8 & 10.3 & 8.2 & -0.1 & 7.6 & -1.4 & 0.1 & -0.2 & 3.9 & 4.7 & 13.6 & 3.1 & -5.1 \\
\hline Finland & 13.3 & 6.4 & 13.7 & 11.1 & 2.7 & 6.0 & 4.3 & -3.0 & 4.0 & 3.5 & 3.4 & 4.8 & 8.7 & 0.3 \\
\hline France & 1.8 & 0.7 & 0.4 & 7.1 & 8.3 & 7.2 & 2.4 & -1.7 & 2.2 & 3.6 & 4.4 & 4.2 & 6.6 & 0.6 \\
\hline Germany & -0.2 & -0.5 & 1.0 & 4.0 & 4.8 & 3.0 & -3.7 & -6.1 & -0.3 & -0.3 & 0.9 & 7.8 & 5.0 & 3.1 \\
\hline Greece & $4.1 \mathrm{e}$ & $8.4 \mathrm{e}$ & $6.8 \mathrm{e}$ & $10.6 \mathrm{e}$ & $11.0 \mathrm{e}$ & $8.0 \mathrm{e}$ & 4.8 & 9.5 & 11.8 & 1.4 & -4.5 & 9.8 & 4.6 & -7.4 \\
\hline Hungary & -4.3 & 3.8 & 6.5 & 11.5 & 6.0 & 7.2 & 4.7 & 10.5 & 2.1 & 7.9 & 5.7 & -3.6 & 1.6 & 0.4 \\
\hline Iceland & -1.7 & 25.0 & 9.3 & 34.4 & -4.1 & 11.8 & -4.3 & -14.0 & 11.1 & 28.1 & 35.7 & 21.7 & -12.8 & -21.8 \\
\hline Ireland & 15.8 & 16.4 & 16.5 & 14.1 & 13.4 & 6.3 & 0.2 & 3.0 & 6.4 & 9.6 & 14.6 & 3.9 & 2.4 & -15.5 \\
\hline Italy & 6.9 & 2.3 & 1.6 & 4.2 & 3.9 & 6.3 & 2.7 & 3.7 & -1.2 & 2.3 & 0.8 & 2.9 & 2.0 & -3.0 \\
\hline Japan & 0.9 & 4.6 & -0.3 & -7.2 & -0.8 & 1.2 & -0.9 & -4.9 & -0.5 & 1.5 & 3.1 & 0.5 & 1.1 & $-5.0 \mathrm{e}$ \\
\hline Korea & $13.1 \mathrm{e}$ & $8.4 \mathrm{e}$ & $-2.3 \mathrm{e}$ & $-22.9 \mathrm{e}$ & $8.3 \mathrm{e}$ & $12.2 \mathrm{e}$ & 0.3 & 7.1 & 4.4 & 2.1 & 1.9 & 3.4 & 4.2 & -1.7 \\
\hline Luxembourg & -1.5 & 4.9 & 10.4 & 6.1 & 22.0 & -4.7 & 8.8 & 5.5 & 6.3 & 2.7 & 2.5 & 4.7 & 12.6 & -0.1 \\
\hline Mexico & $-29.0 \mathrm{e}$ & $16.4 \mathrm{e}$ & $21.0 \mathrm{e}$ & $10.3 \mathrm{e}$ & $7.7 \mathrm{e}$ & $11.4 \mathrm{e}$ & $-5.6 \mathrm{e}$ & $-0.6 \mathrm{e}$ & $0.4 \mathrm{e}$ & 8.0 & 7.5 & 9.8 & 7.2 & $4.9 \mathrm{e}$ \\
\hline Netherlands & 5.9 & 8.5 & 8.5 & 6.8 & 8.7 & 0.6 & 0.2 & -4.6 & -1.6 & -1.6 & 3.7 & 7.5 & 4.8 & 4.9 \\
\hline New Zealand & 11.1 & 5.1 & 0.2 & -2.4 & 10.6 & 0.4 & 6.8 & 7.8 & 12.9 & 7.6 & 5.2 & -2.3 & $4.7 \mathrm{e}$ & $-5.2 \mathrm{e}$ \\
\hline Norway & 3.9 & 10.2 & 15.8 & 13.7 & -5.4 & -3.5 & -1.1 & -1.1 & 0.2 & 10.2 & 13.3 & 11.7 & 8.4 & 3.9 \\
\hline Poland & 16.6 & 19.7 & 21.8 & 14.0 & 6.6 & 2.8 & -9.7 & -6.3 & -0.1 & 6.4 & 6.5 & 14.9 & 17.6 & 8.2 \\
\hline Portugal & 6.6 & 5.6 & 14.3 & 11.7 & 6.2 & 3.5 & 1.0 & -3.5 & -7.4 & 0.2 & -0.9 & -0.7 & 3.1 & -0.7 \\
\hline Slovak Republic & 0.6 & 30.1 & 14.0 & 9.4 & -15.7 & -9.6 & 12.9 & 0.2 & -2.7 & 4.8 & 17.6 & 9.3 & 8.7 & 6.8 \\
\hline Spain & 7.8 & 2.6 & 5.0 & 11.3 & 10.4 & 6.6 & 4.8 & 3.4 & 5.9 & 5.1 & 7.0 & 7.2 & 4.6 & -4.4 \\
\hline Sweden & 10.0 & 4.7 & -0.1 & 8.1 & 8.5 & 6.3 & -0.5 & -1.8 & 1.4 & 5.7 & 8.9 & 9.1 & 7.5 & 2.7 \\
\hline Switzerland & 4.8 & -1.7 & 2.1 & 6.4 & 1.5 & 4.2 & -3.5 & -0.5 & -1.2 & 4.5 & 3.8 & 4.7 & 5.2 & 0.4 \\
\hline Turkey & $9.1 \mathrm{e}$ & $14.1 \mathrm{e}$ & $14.8 \mathrm{e}$ & -3.9 & -16.2 & 17.5 & -30.0 & 14.7 & 14.2 & 28.4 & 17.4 & 13.3 & 3.1 & -5.0 \\
\hline United Kingdom & 2.9 & 5.4 & 6.8 & 13.7 & 3.0 & 2.7 & 2.6 & 3.7 & 1.1 & 4.9 & 2.3 & 6.0 & 6.8 & -3.1 \\
\hline United States & 6.3 & 8.5 & 8.8 & 9.9 & 9.1 & 6.9 & -1.1 & -3.0 & 2.9 & 6.2 & 5.3 & 2.3 & -1.4 & -4.2 \\
\hline Euro area & .. & 1.8 & 2.8 & 6.0 & 6.1 & 4.8 & 0.6 & -1.4 & 1.3 & 2.3 & 3.2 & 5.5 & 4.9 & -0.3 \\
\hline OECD-Total &.. & $6.0 \mathrm{e}$ & $5.6 \mathrm{e}$ & $3.8 \mathrm{e}$ & $5.4 \mathrm{e}$ & $5.2 \mathrm{e}$ & $-0.7 \mathrm{e}$ & $-1.0 \mathrm{e}$ & $2.2 \mathrm{e}$ & 4.7 & 4.8 & 4.3 & 2.7 & $-1.8 \mathrm{e}$ \\
\hline
\end{tabular}

Figure 12.1. Gross fixed capital formation, volume

Annual growth rates in percentage, 2008

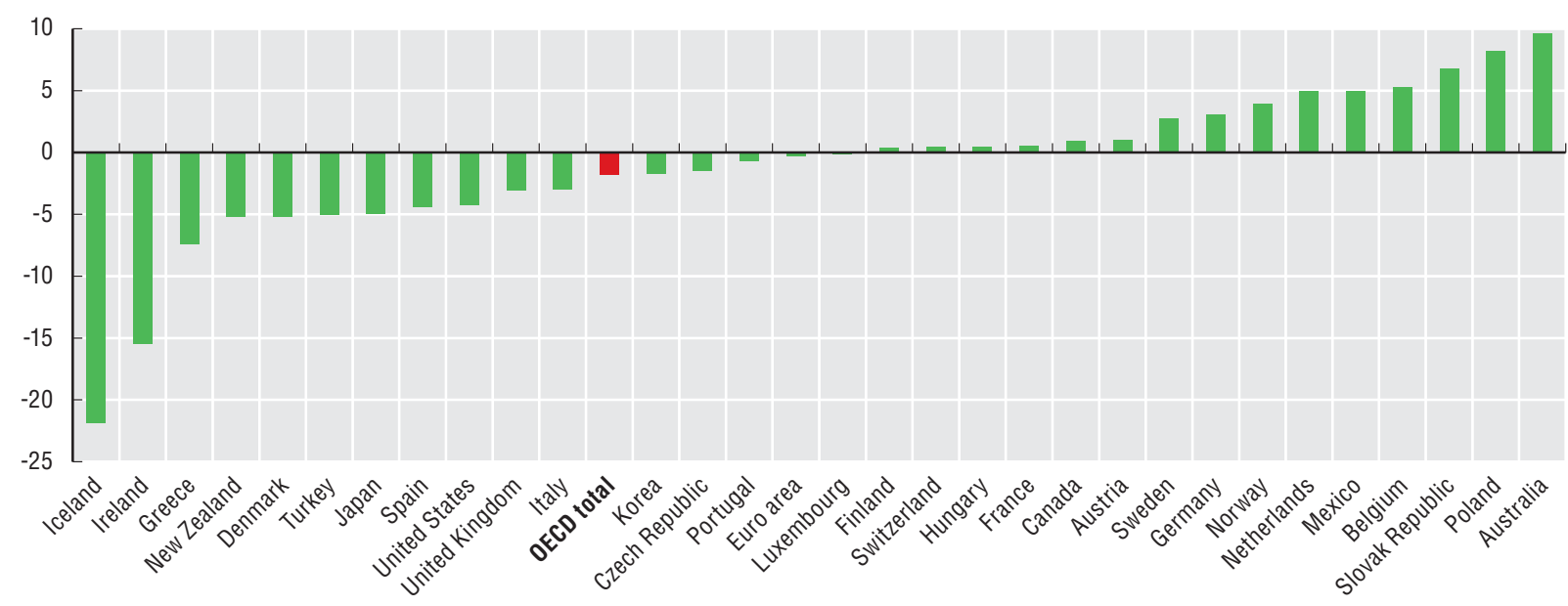


Table 12.2. Gross fixed capital formation by asset

Percentage of total GFCF

\begin{tabular}{|c|c|c|c|c|c|c|c|c|c|c|c|c|}
\hline & \multicolumn{2}{|c|}{ Dwellings } & \multicolumn{2}{|c|}{ Other buildings and structures } & \multicolumn{2}{|c|}{ Transport equipment } & \multicolumn{2}{|c|}{ Other machinery and equipment } & \multicolumn{2}{|c|}{ Cultivated assets } & \multicolumn{2}{|c|}{ Intangible fixed assets } \\
\hline & 1997 & 2007 & 1997 & 2007 & 1997 & 2007 & 1997 & 2007 & 1997 & 2007 & 1997 & 2007 \\
\hline Australia & 23.2 & 21.7 & 29.2 & 35.7 & 11.2 & 9.7 & 23.7 & 20.2 & 0.9 & 0.8 & 6.6 & 6.0 \\
\hline Austria & 27.2 & 21.9 & 29.5 & 31.6 & 9.7 & 12.0 & 29.3 & 26.3 & 0.2 & 0.3 & 4.2 & 7.9 \\
\hline Belgium & .. & .. & .. & .. & .. & .. & .. & .. & .. & .. & .. & .. \\
\hline Canada & 25.0 & 31.4 & 32.0 & 33.6 & 10.4 & 7.8 & 26.2 & 19.9 & .. & .. & 6.5 & 7.2 \\
\hline Czech Republic & 11.0 & 15.2 & 42.1 & 35.1 & 7.4 & 15.4 & 36.3 & 29.2 & 0.8 & 0.5 & 2.4 & 4.6 \\
\hline Denmark & 21.9 & 31.3 & 28.0 & 22.6 & 11.2 & 9.6 & 31.0 & 27.1 & -0.0 & 0.0 & 8.0 & 9.3 \\
\hline Finland & 24.3 & 28.3 & 30.2 & 36.5 & 7.9 & 6.4 & 30.9 & 20.0 & 0.3 & 0.2 & 6.5 & 8.7 \\
\hline France & 30.7 & 32.1 & 28.3 & 30.9 & 7.1 & 7.9 & 25.6 & 20.4 & 0.5 & 0.3 & 7.7 & 8.5 \\
\hline Germany & 35.3 & 29.1 & 26.0 & 21.7 & 8.5 & 13.5 & 25.6 & 29.6 & -0.0 & -0.0 & 4.6 & 6.1 \\
\hline Greece & 38.4 & 35.6 & 29.7 & 18.3 & 10.1 & 15.0 & 20.5 & 26.5 & 0.2 & 0.2 & 3.5 & 4.5 \\
\hline Hungary & 20.9 & 19.0 & 34.6 & 35.6 & 0.7 & 9.5 & 40.0 & 31.3 & 1.8 & 0.7 & 2.0 & 3.9 \\
\hline Iceland & .. & .. & .. & .. & .. & .. & .. & .. & .. & .. & .. & .. \\
\hline Ireland & 33.3 & 47.1 & 29.0 & 30.4 & 13.8 & 11.4 & 20.2 & 9.6 & 0.5 & -0.1 & 3.3 & 1.6 \\
\hline Italy & 22.9 & 24.0 & 25.7 & 27.3 & 9.5 & 9.8 & 37.4 & 34.7 & 0.1 & 0.1 & 4.3 & 4.1 \\
\hline Japan & 18.1 & 14.8 & 39.1 & 37.4 & 6.8 & 8.4 & 31.8 & 33.2 & 0.1 & 0.1 & 6.2 & 8.8 \\
\hline Korea & 17.3 & 16.9 & 44.7 & 44.6 & 8.1 & 7.1 & 26.1 & 25.2 & .. & .. & 3.6 & 6.2 \\
\hline Luxembourg & 13.6 & 9.5 & 35.8 & 47.7 & 19.9 & 16.7 & 23.1 & 15.9 & 0.1 & 0.1 & 7.6 & 10.2 \\
\hline Mexico &.. & 27.0 & .. & 38.4 & .. & 10.1 & .. & 24.5 & .. & 0.0 & .. & .. \\
\hline Netherlands & 26.5 & 32.1 & 24.3 & 25.9 & 9.0 & 8.4 & 30.6 & 23.9 & 1.1 & 0.4 & 8.5 & 9.3 \\
\hline New Zealand & 27.8 & 28.6 & 26.1 & 29.4 & 10.4 & 10.3 & 29.5 & 24.7 & .. & .. & 6.3 & 7.1 \\
\hline Norway & 62.2 & 68.7 & .. & .. & 12.4 & 8.9 & 19.3 & 15.6 & .. & .. & 3.1 & 3.4 \\
\hline Poland & 10.8 & 14.1 & 42.6 & 42.4 & 9.3 & 10.6 & 33.9 & 29.0 & 0.5 & 0.2 & 2.8 & 3.8 \\
\hline Portugal & 54.0 & .. & .. & .. & 10.8 & & 23.2 & .. & 1.1 & .. & 11.1 & .. \\
\hline Slovak Republic & 5.3 & 9.0 & 40.5 & 42.4 & 7.8 & 10.3 & 36.3 & 28.4 & 7.2 & 3.2 & 2.8 & 6.8 \\
\hline Spain & 21.6 & 30.1 & 31.1 & 27.8 & 8.5 & 7.9 & 22.7 & 16.9 & 0.4 & 0.1 & 15.7 & 17.1 \\
\hline Sweden & 9.1 & 17.6 & 28.9 & 24.7 & 7.5 & 9.2 & 41.4 & 32.4 & 0.6 & 0.3 & 12.5 & 15.7 \\
\hline Switzerland & 20.5 & 21.1 & 18.3 & 14.6 & 7.2 & 6.5 & 49.1 & 49.9 & 0.2 & 0.2 & 4.7 & 7.8 \\
\hline Turkey & .. & 45.8 & .. & .. & .. & .. & .. & 54.2 & .. & .. & .. & .. \\
\hline United Kingdom & 17.3 & 22.5 & 29.9 & 37.1 & 9.1 & 6.2 & 37.2 & 27.8 & .. & .. & 6.5 & 6.5 \\
\hline United States & 22.8 & 23.7 & 25.7 & 30.7 & 9.7 & 7.5 & 33.8 & 27.8 & .. & .. & 8.1 & 10.3 \\
\hline Euro area & .. & .. & .. & .. & .. & .. & .. & .. & .. & .. & .. & .. \\
\hline OECD-Total & .. & .. & .. & .. & .. & .. & .. & .. & .. & .. & .. & .. \\
\hline
\end{tabular}

Figure 12.2. Investment in information and communication technologies (ICT)

Percentage of total gross fixed capital formation

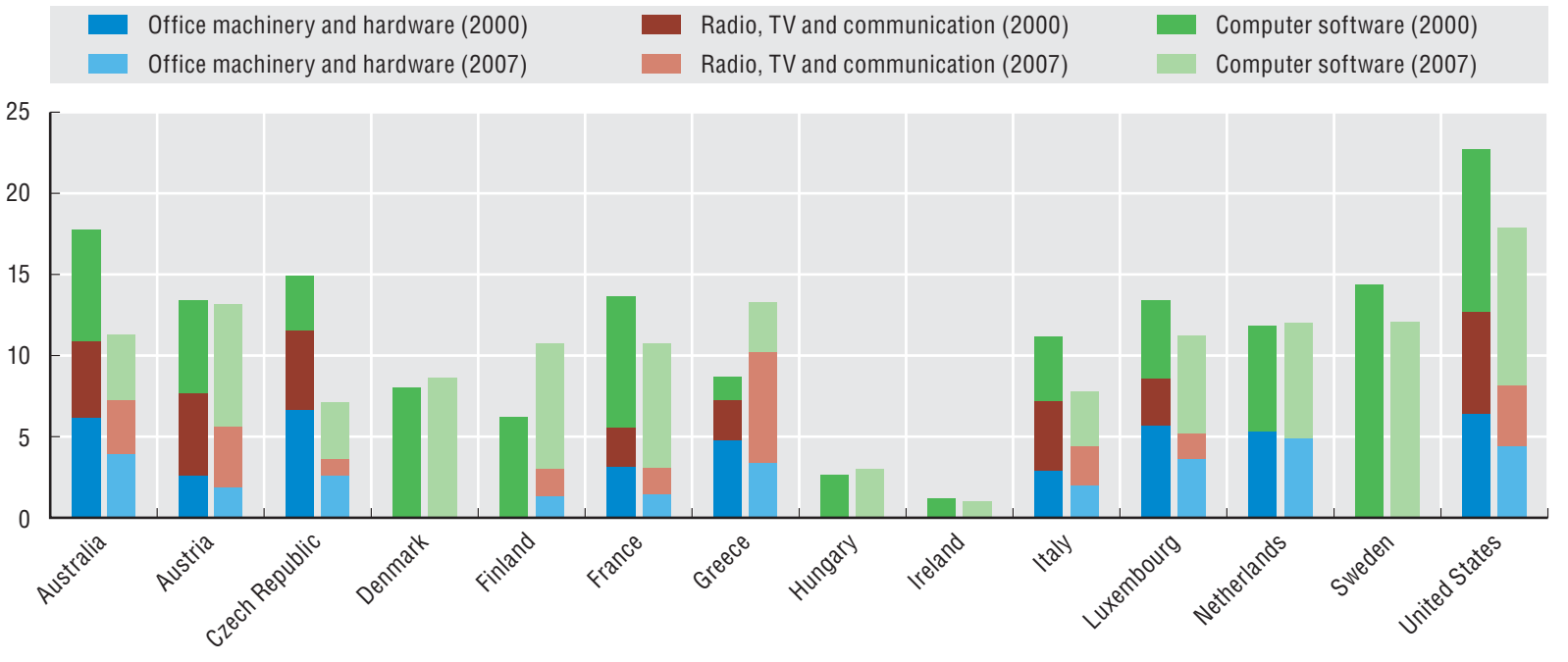

StatLink काIs http://dx.doi.org/10.1787/738861251562 
Table 12.3. Gross fixed capital formation by institutional sector

\begin{tabular}{|c|c|c|c|c|c|c|c|c|c|c|c|c|}
\hline \multicolumn{13}{|c|}{ Percentage of total GFCF } \\
\hline & \multicolumn{4}{|c|}{ Corporations } & \multicolumn{4}{|c|}{ General government } & \multicolumn{4}{|c|}{ Households and non-profit institutions serving households } \\
\hline & 1995 & 1999 & 2003 & 2007 & 1995 & 1999 & 2003 & 2007 & 1995 & 1999 & 2003 & 2007 \\
\hline Australia & 53.3 & 49.4 & 47.4 & .. & 10.3 & 9.8 & 8.8 &.. & 36.4 & 40.8 & 43.9 & .. \\
\hline Austria & 63.3 & 69.3 & 72.5 & 72.3 & 12.8 & 7.4 & 5.3 & 4.7 & 23.9 & 23.4 & 22.2 & 23.0 \\
\hline Belgium & 56.4 & 61.2 & 63.0 & 63.3 & 9.6 & 9.4 & 8.8 & 7.4 & 34.0 & 29.4 & 28.2 & 29.3 \\
\hline Canada & 55.0 & 60.8 & 54.1 & 54.3 & 15.0 & 11.8 & 12.6 & 13.2 & 30.1 & 27.4 & 33.3 & 32.6 \\
\hline Czech Republic & 69.2 & 69.6 & 65.2 & 59.8 & 16.7 & 12.0 & 17.0 & 18.7 & 14.1 & 18.3 & 17.8 & 21.5 \\
\hline Denmark & 68.1 & 64.4 & 66.9 & 62.5 & 9.6 & 8.4 & 8.2 & 7.9 & 22.3 & 27.2 & 24.8 & 29.6 \\
\hline Finland & 59.3 & 55.8 & 54.2 & 57.0 & 16.2 & 14.5 & 16.0 & 12.4 & 24.6 & 29.6 & 29.8 & 30.7 \\
\hline France & 50.7 & 53.7 & 53.0 & 52.5 & 17.6 & 15.6 & 16.3 & 15.2 & 31.7 & 30.7 & 30.7 & 32.2 \\
\hline Germany & 50.6 & 54.3 & 56.5 & 59.1 & 10.0 & 8.8 & 8.7 & 7.5 & 39.4 & 37.0 & 34.7 & 33.3 \\
\hline Greece &.. &.. & 34.1 &.. &.. &.. & 14.9 &.. &.. &.. & 51.0 & .. \\
\hline Hungary & 61.7 & 67.9 & 56.4 & 59.8 & 0.9 & 12.5 & 15.7 & 16.8 & 37.4 & 19.6 & 27.9 & 23.4 \\
\hline Iceland &.. &.. &.. &.. &.. &.. & .. &.. &.. &.. &.. &.. \\
\hline Ireland & .. &.. & 36.6 & 36.6 &.. &.. & 16.6 & 15.5 &.. &.. & 46.9 & 47.9 \\
\hline Italy & 55.8 & 56.9 & 57.5 & 57.3 & 10.8 & 12.1 & 12.1 & 11.0 & 33.4 & 31.0 & 30.4 & 31.7 \\
\hline Japan &.. & 56.2 & 61.1 & 69.4 &.. & 23.1 & 18.8 & 13.3 &.. & 20.7 & 20.2 & 17.2 \\
\hline Korea &.. &.. & 61.6 & 66.6 &.. &.. & 19.5 & 17.0 &.. &.. & 18.9 & 16.4 \\
\hline Luxembourg & .. & .. & .. & .. & .. &.. & .. & .. & .. & .. & .. & .. \\
\hline Mexico &.. &.. & .. & .. &.. &.. & .. &.. &.. &.. &.. &.. \\
\hline Netherlands & 54.7 & 55.1 & 47.4 & 46.3 & 15.2 & 13.2 & 18.2 & 16.7 & 30.1 & 31.7 & 34.4 & 37.0 \\
\hline New Zealand & .. & .. & .. & .. & .. & .. & .. & & .. & .. & .. & .. \\
\hline Norway & 62.0 & 63.8 & 57.3 & 62.5 & 16.0 & 15.5 & 17.2 & 13.2 & 22.0 & 20.7 & 25.5 & 24.3 \\
\hline Poland & 58.4 & 68.0 & 54.4 & 57.6 & 18.5 & 14.3 & 18.3 & 19.0 & 23.1 & 17.7 & 27.4 & 23.4 \\
\hline Portugal & 52.2 & 56.5 & 59.7 & 65.0 & 16.8 & 15.1 & 13.6 & 10.6 & 31.0 & 28.4 & 26.7 & 24.5 \\
\hline Slovak Republic & 76.9 & 71.3 & 67.3 & 72.4 & 9.5 & 9.9 & 10.4 & 7.2 & 13.6 & 18.8 & 22.3 & 20.4 \\
\hline Spain & .. &.. & 55.4 & 56.2 &.. &.. & 13.2 & 12.4 & .. & .. & 31.4 & 31.5 \\
\hline Sweden & 66.4 & 71.6 & 68.6 & 67.9 & 24.5 & 18.1 & 18.1 & 16.3 & 9.1 & 10.3 & 13.4 & 15.8 \\
\hline Switzerland & 59.6 & 63.9 & 63.7 & 68.4 & 13.2 & 11.7 & 12.0 & 8.8 & 27.2 & 24.4 & 24.4 & 22.8 \\
\hline Turkey &.. &.. & .. &.. &.. &.. & .. &.. & .. & .. & .. &.. \\
\hline United Kingdom & 64.6 & 68.6 & 59.4 & 56.8 & 12.0 & 7.8 & 11.0 & 10.3 & 23.4 & 23.6 & 29.6 & 33.0 \\
\hline United States & 53.2 & 53.9 & 46.8 & 51.9 & 13.2 & 12.4 & 13.7 & 13.0 & 33.6 & 33.8 & 39.5 & 35.1 \\
\hline Euro area & .. & .. & .. & .. & .. & .. & .. &.. & .. & .. & .. & .. \\
\hline OECD-Total &.. & .. &.. &.. & .. & .. & .. & .. & .. & .. & .. & .. \\
\hline
\end{tabular}

Figure 12.3. Gross fixed capital formation by sector

Percentage of total gross fixed capital formation, 2007

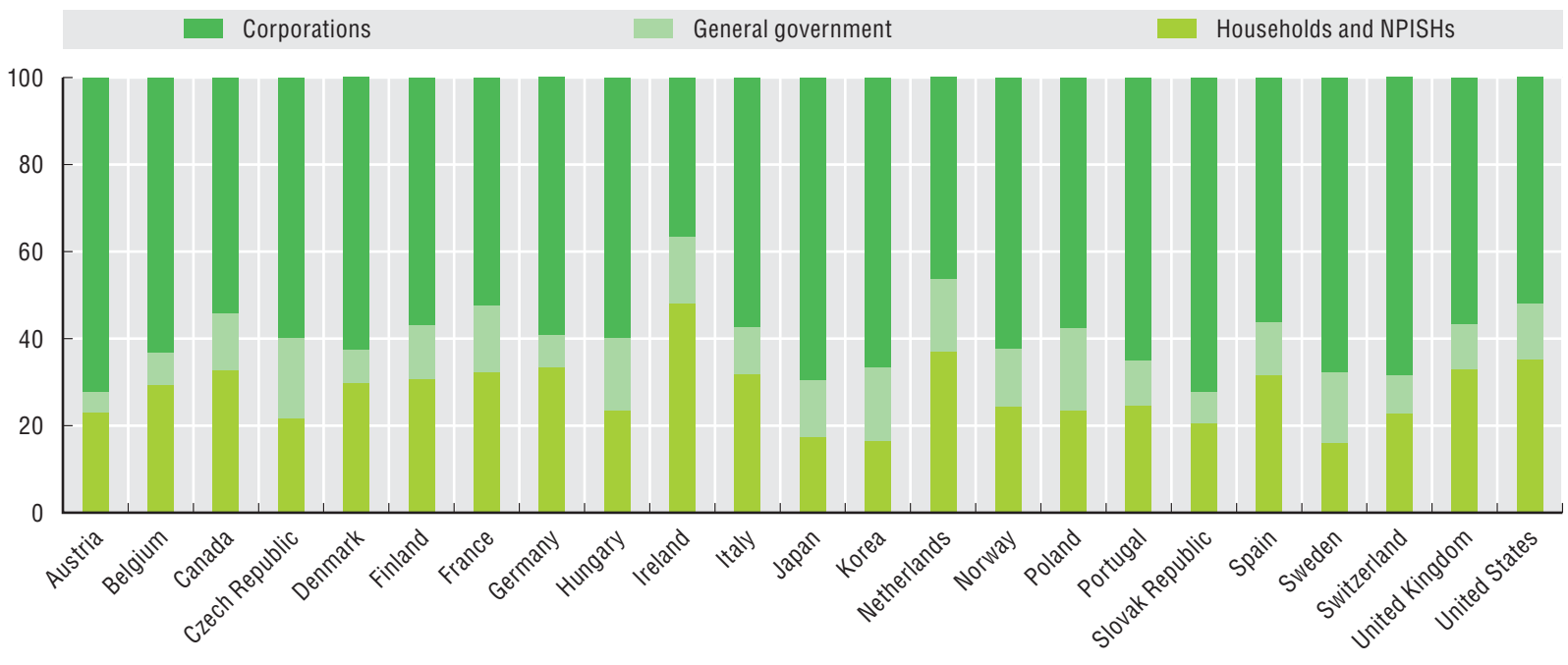

StatLink काIs http://dx.doi.org/10.1787/740037250208 
In today's increasingly globalised world, exports and imports are key aggregates in the analysis of a country's economic situation. Whenever an economy slows down or accelerates, all other economies are potentially affected.

\section{Definition}

Exports of goods and services consist of sales, barter or gifts or grants, of goods and services (included in the production boundary of GDP) from residents to non-residents. Equally, imports reflect the same transactions from nonresidents to residents.

A unit is said to be resident in a country when its "centre of economic interest" is situated in that country's economic territory. A country's economic territory is the geographic area corresponding to the nation state. It includes its air space, its territorial waters, its territorial enclaves in the rest of the world (embassies in foreign countries) and free zones. Conversely, it excludes foreign embassies located in the country.

Not all goods need to physically enter a country's border to be recorded as an export or import. Transportation equipment, goods produced by residents in international waters sold directly to non-residents, and food consumed in ships or planes are but a few examples of transactions which may be recorded as exports or imports without physically crossing borders.

Equally not all goods that enter a country's borders are necessarily imports or exports. Transportation equipment, goods sent abroad for minor processing (or which enter and leave a country in their original state and ownership) are examples of goods that cross borders but are not recorded as imports or exports.

A number of indicators can be derived from exports and imports of goods and services. For example the degree of openness (export + imports)/GDP or the terms of trade which are shown here in Table 13.3. The terms of trade are defined as the ratio between the index of export prices and the index of import prices.

\section{Comparability}

Goods (merchandise trade) reflect the bulk of import and exports, and these are generally well covered and afford good comparability across countries; although discrepancies between total imports and exports of traded goods at the global level reveal that measurement in practice is not trivial. Growth in trade through the Internet has increased measurement difficulties.

The comparability of trade in services is greater affected by practical measurement issues however; even if the conceptual approach, as it is for goods, is the same for all OECD countries.

Until recently, exports and imports of services mainly consisted of transport services (sea, air) and insurance. But increases in outsourcing, merchanting, processing services (see also Annex B for changes implied by the 2008 SNA) and transactions in intellectual property, such as software and artistic originals, have increased the difficulties inherent in the measurement of trade in services. Some payments, for example in software, are incorrectly recorded as property income say and not in the goods and services accounts.

\section{Source}

- OECD (2009), National Accounts of OECD Countries 2009, Volume I, Main Aggregates, OECD Publishing, http://dx.doi.org/10.1787/na_vol_1-2009-en-fr.

\section{Online database}

- OECD (2009), "Aggregate national accounts: gross domestic product", OECD National Accounts Statistics (database), http://dx.doi.org/10.1787/data-00001-en.

\section{Further reading}

- Lequiller, F. and D. Blades (2007), Understanding National Accounts, OECD Publishing, http://dx.doi.org/10.1787/9789264027657-en.

- OECD (2000), System of National Accounts, 1993 Glossary, OECD Publishing, http://dx.doi.org/10.1787/9789264180871-en.

- UN, OECD, IMF, Eurostat (eds.) (1993), System of National Accounts 1993, United Nations, Geneva, http://unstats.un.org/unsd/sna1993. 
Table 13.1. Exports of goods and services, volume

Annual growth rates in percentage

\begin{tabular}{|c|c|c|c|c|c|c|c|c|c|c|c|c|c|c|}
\hline & 1995 & 1996 & 1997 & 1998 & 1999 & 2000 & 2001 & 2002 & 2003 & 2004 & 2005 & 2006 & 2007 & 2008 \\
\hline Australia & 10.0 & 11.0 & 4.2 & 2.2 & 8.5 & 7.6 & -1.0 & -0.4 & 2.1 & 3.1 & 2.2 & 3.8 & 4.5 & $3.8 \mathrm{e}$ \\
\hline Austria & 7.2 & 4.6 & 11.8 & 8.4 & 6.1 & 13.4 & 6.2 & 3.9 & 1.5 & 10.1 & 7.4 & 7.5 & 9.4 & 0.8 \\
\hline Belgium & 5.0 & 3.1 & 6.2 & 5.9 & 5.0 & 8.4 & 0.9 & 1.2 & 2.9 & 6.6 & 3.6 & 2.6 & 4.0 & 2.2 \\
\hline Canada & 8.5 & 5.6 & 8.3 & 9.1 & 10.7 & 8.9 & -3.0 & 1.2 & -2.3 & 5.0 & 1.8 & 0.6 & 1.0 & $-4.7 \mathrm{e}$ \\
\hline Czech Republic & 16.7 & 5.5 & 8.4 & 10.4 & 5.4 & 16.6 & 11.2 & 2.1 & 7.2 & 20.7 & 11.6 & 15.8 & 15.0 & 6.0 \\
\hline Denmark & 3.1 & 4.2 & 4.9 & 4.1 & 11.6 & 12.7 & 3.1 & 4.1 & -1.0 & 2.8 & 8.0 & 9.1 & 2.2 & 2.2 \\
\hline Finland & 8.5 & 5.9 & 14.0 & 9.2 & 11.3 & 17.2 & 2.1 & 2.8 & -1.7 & 8.6 & 7.0 & 11.8 & 8.1 & 7.3 \\
\hline France & 8.4 & 3.7 & 12.9 & 8.2 & 4.6 & 12.4 & 2.5 & 1.5 & -1.2 & 4.0 & 3.2 & 4.8 & 2.6 & -0.2 \\
\hline Germany & 6.4 & 6.1 & 11.7 & 8.0 & 5.9 & 13.5 & 6.4 & 4.3 & 2.5 & 10.3 & 7.7 & 13.0 & 7.5 & 2.9 \\
\hline Greece & $3.0 \mathrm{e}$ & $3.5 \mathrm{e}$ & $20.0 \mathrm{e}$ & $5.3 \mathrm{e}$ & $18.1 \mathrm{e}$ & $14.1 \mathrm{e}$ & -0.0 & -8.4 & 2.9 & 17.4 & 2.4 & 5.3 & 5.8 & 4.0 \\
\hline Hungary & 36.4 & 11.2 & 20.9 & 16.5 & 11.1 & 19.7 & 8.1 & 3.9 & 6.2 & 15.0 & 11.3 & 18.6 & 16.2 & 5.6 \\
\hline Iceland & -2.3 & 9.9 & 5.6 & 2.5 & 4.0 & 4.2 & 7.4 & 3.8 & 1.6 & 8.4 & 7.1 & -4.9 & 17.7 & 7.1 \\
\hline Ireland & 20.0 & 12.5 & 17.6 & 23.1 & 15.6 & 20.3 & 8.6 & 5.0 & 0.6 & 7.5 & 5.2 & 5.1 & 8.6 & -1.1 \\
\hline Italy & 12.4 & 1.5 & 5.1 & 2.5 & -0.4 & 11.9 & 2.6 & -2.9 & -2.0 & 4.9 & 1.1 & 6.2 & 4.6 & -3.7 \\
\hline Japan & 4.4 & 5.9 & 11.1 & -2.7 & 1.9 & 12.7 & -6.9 & 7.5 & 9.2 & 13.9 & 7.0 & 9.7 & 8.4 & $1.8 \mathrm{e}$ \\
\hline Korea & $24.4 \mathrm{e}$ & $12.2 \mathrm{e}$ & $21.6 \mathrm{e}$ & $12.7 \mathrm{e}$ & $14.6 \mathrm{e}$ & $19.1 \mathrm{e}$ & -3.4 & 12.1 & 14.5 & 19.7 & 7.8 & 11.4 & 12.6 & 5.7 \\
\hline Luxembourg & 4.6 & 2.3 & 11.4 & 11.2 & 14.3 & 12.6 & 4.5 & 2.1 & 6.8 & 11.1 & 4.5 & 13.3 & 8.8 & 1.5 \\
\hline Mexico & $30.2 \mathrm{e}$ & $18.2 \mathrm{e}$ & $10.7 \mathrm{e}$ & $12.1 \mathrm{e}$ & $12.4 \mathrm{e}$ & $16.3 \mathrm{e}$ & $-3.6 \mathrm{e}$ & $1.4 \mathrm{e}$ & $2.7 \mathrm{e}$ & 11.5 & 6.8 & 10.9 & 5.7 & $1.4 \mathrm{e}$ \\
\hline Netherlands & 9.2 & 4.4 & 10.9 & 6.8 & 8.7 & 13.5 & 1.9 & 0.9 & 1.5 & 7.9 & 6.0 & 7.3 & 6.7 & 2.7 \\
\hline New Zealand & 2.3 & 4.7 & 3.9 & 2.9 & 7.4 & 6.3 & 3.0 & 7.9 & 0.9 & 4.6 & -0.1 & 3.1 & 2.9 & $-1.3 e$ \\
\hline Norway & 5.0 & 10.0 & 7.8 & 0.7 & 2.9 & 3.2 & 4.3 & -0.3 & -0.2 & 1.1 & 1.1 & 0.0 & 2.5 & 1.4 \\
\hline Poland & 22.9 & 12.0 & 12.3 & 14.4 & -2.5 & 23.2 & 3.1 & 4.8 & 14.2 & 14.0 & 8.0 & 14.6 & 9.1 & 7.1 \\
\hline Portugal & 8.8 & 5.7 & 6.1 & 8.5 & 3.0 & 8.4 & 1.8 & 1.5 & 3.9 & 4.0 & 2.0 & 8.7 & 7.8 & -0.5 \\
\hline Slovak Republic & 4.6 & -1.4 & 5.8 & 21.0 & 12.2 & 8.9 & 6.9 & 5.4 & 15.9 & 7.4 & 10.0 & 21.0 & 13.8 & 3.2 \\
\hline Spain & 9.4 & 10.3 & 15.0 & 8.0 & 7.5 & 10.2 & 4.2 & 2.0 & 3.7 & 4.2 & 2.5 & 6.7 & 6.7 & -1.0 \\
\hline Sweden & 11.3 & 4.1 & 13.6 & 8.7 & 7.1 & 11.5 & 0.8 & 1.3 & 4.0 & 11.0 & 6.6 & 8.9 & 5.8 & 1.9 \\
\hline Switzerland & 0.6 & 3.7 & 11.2 & 4.3 & 6.5 & 12.5 & 0.5 & -0.1 & -0.5 & 7.9 & 7.8 & 10.3 & 9.6 & 2.9 \\
\hline Turkey & $8.0 \mathrm{e}$ & $22.0 \mathrm{e}$ & $19.1 \mathrm{e}$ & 12.0 & -10.7 & 16.0 & 3.9 & 6.9 & 6.9 & 11.2 & 7.9 & 6.6 & 7.3 & 2.3 \\
\hline United Kingdom & 9.5 & 8.8 & 8.2 & 3.1 & 3.7 & 9.1 & 3.0 & 1.0 & 1.8 & 4.8 & 8.1 & 11.0 & -4.1 & 0.1 \\
\hline United States & 10.1 & 8.3 & 11.9 & 2.3 & 4.4 & 8.6 & -5.6 & -2.0 & 1.6 & 9.5 & 6.7 & 9.0 & 8.7 & 5.4 \\
\hline Euro area &.. & 4.8 & 10.8 & 7.5 & 5.9 & 12.7 & 3.9 & 1.9 & 1.3 & 7.4 & 5.0 & 8.3 & 6.1 & 1.2 \\
\hline OECD-Total &.. & $7.3 \mathrm{e}$ & $11.1 \mathrm{e}$ & $6.2 \mathrm{e}$ & $5.9 \mathrm{e}$ & $12.1 \mathrm{e}$ & $0.5 \mathrm{e}$ & $2.0 \mathrm{e}$ & $2.9 \mathrm{e}$ & 9.0 & 6.0 & 8.8 & 6.5 & $2.2 \mathrm{e}$ \\
\hline
\end{tabular}

Figure 13.1. Exports of goods and services, volume

Annual growth rates in percentage, 2008

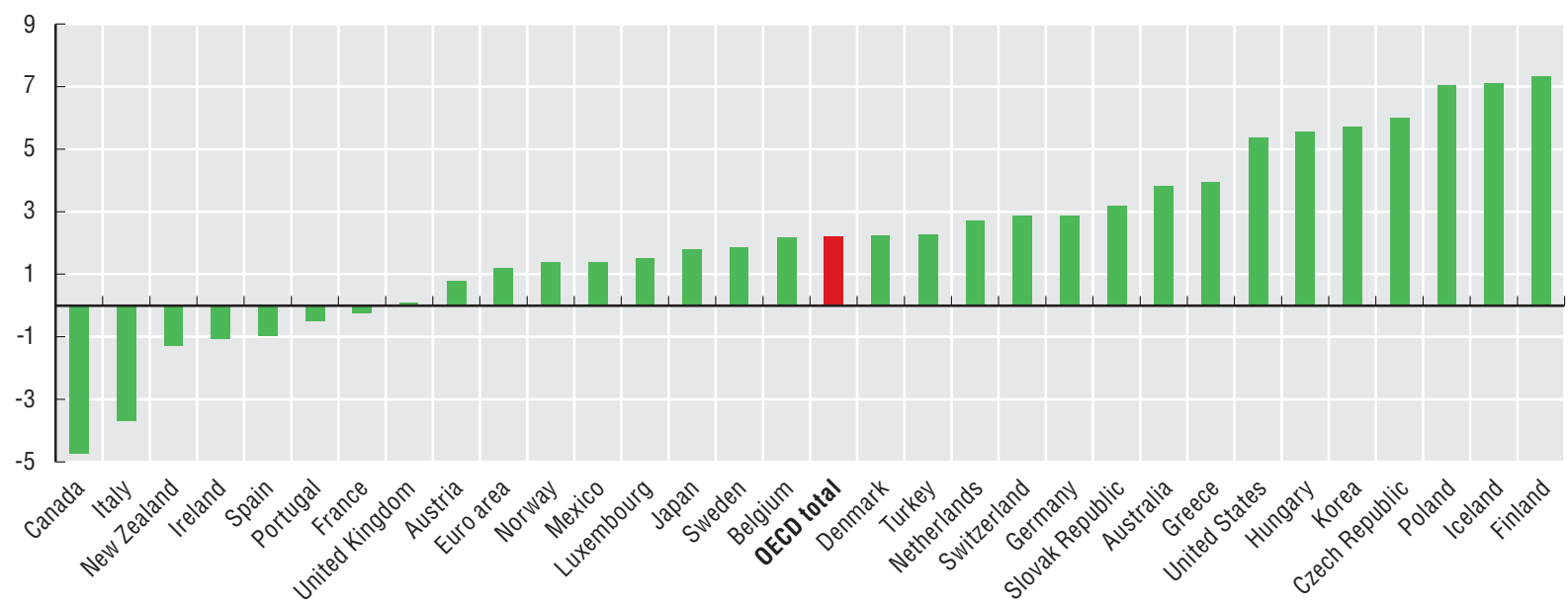

StatLink लाड़ http://dx.doi.org/10.1787/740055502432 
Table 13.2. Imports of goods and services, volume

Annual growth rates in percentage

\begin{tabular}{|c|c|c|c|c|c|c|c|c|c|c|c|c|c|c|}
\hline & 1995 & 1996 & 1997 & 1998 & 1999 & 2000 & 2001 & 2002 & 2003 & 2004 & 2005 & 2006 & 2007 & 2008 \\
\hline Australia & 4.0 & 9.9 & 10.0 & 5.0 & 12.4 & $\begin{array}{l}-1.0 \\
\end{array}$ & 1.5 & 13.1 & 13.0 & 12.1 & 7.2 & 9.2 & 12.7 & $11.1 \mathrm{e}$ \\
\hline Austria & 5.9 & 4.4 & 7.7 & 5.2 & 4.7 & 10.6 & 5.6 & -0.4 & 4.5 & 9.8 & 6.4 & 5.3 & 7.3 & -0.7 \\
\hline Belgium & 4.7 & 2.7 & 5.2 & 6.9 & 4.4 & 8.8 & 0.2 & 0.2 & 3.0 & 6.6 & 4.2 & 2.7 & 4.6 & 3.3 \\
\hline Canada & 5.7 & 5.1 & 14.2 & 5.1 & 7.8 & 8.1 & -5.1 & 1.7 & 4.1 & 8.0 & 7.1 & 4.6 & 5.5 & $0.8 \mathrm{e}$ \\
\hline Czech Republic & 21.2 & 12.1 & 6.9 & 8.3 & 5.0 & 16.3 & 12.8 & 5.0 & 8.0 & 17.9 & 5.0 & 14.3 & 14.3 & 4.7 \\
\hline Denmark & 7.2 & 3.3 & 9.5 & 8.5 & 3.5 & 13.0 & 1.9 & 7.5 & -1.6 & 7.7 & 11.1 & 13.9 & 2.8 & 3.4 \\
\hline Finland & 7.8 & 6.5 & 11.4 & 8.2 & 3.6 & 18.7 & 2.2 & 3.3 & 3.0 & 7.2 & 11.8 & 7.8 & 6.5 & 7.0 \\
\hline France & 7.2 & 2.1 & 7.9 & 11.6 & 6.7 & 14.9 & 2.2 & 1.7 & 1.2 & 7.1 & 6.0 & 5.6 & 5.4 & 0.8 \\
\hline Germany & 6.5 & 3.5 & 8.2 & 9.5 & 8.6 & 10.2 & 1.2 & -1.4 & 5.4 & 7.3 & 6.7 & 11.9 & 4.8 & 4.3 \\
\hline Greece & $9.0 \mathrm{e}$ & $7.0 \mathrm{e}$ & $14.2 \mathrm{e}$ & $9.2 \mathrm{e}$ & $15.0 \mathrm{e}$ & $15.1 \mathrm{e}$ & 1.2 & -1.3 & 3.0 & 5.2 & -0.3 & 9.1 & 7.1 & 0.2 \\
\hline Hungary & 15.1 & 9.1 & 22.3 & 22.9 & 12.3 & 18.0 & 5.3 & 6.8 & 9.3 & 13.7 & 7.0 & 14.8 & 13.3 & 5.7 \\
\hline Iceland & 3.6 & 16.5 & 8.0 & 23.4 & 4.4 & 8.6 & -9.1 & -2.6 & 10.7 & 14.5 & 29.3 & 10.4 & -1.0 & -18.0 \\
\hline Ireland & 16.4 & 12.9 & 16.6 & 27.5 & 12.4 & 21.7 & 7.1 & 2.3 & -1.5 & 8.6 & 8.4 & 6.5 & 5.7 & -2.1 \\
\hline Italy & 9.3 & -0.5 & 9.4 & 9.4 & 4.9 & 9.8 & 1.8 & 0.2 & 1.2 & 4.2 & 2.1 & 5.9 & 3.8 & -4.5 \\
\hline Japan & 13.4 & 13.4 & 0.5 & -6.8 & 3.6 & 9.2 & 0.6 & 0.9 & 3.9 & 8.1 & 5.8 & 4.2 & 1.5 & $0.9 \mathrm{e}$ \\
\hline Korea & $23.0 \mathrm{e}$ & $14.3 \mathrm{e}$ & $3.5 \mathrm{e}$ & $-21.8 \mathrm{e}$ & $27.8 \mathrm{e}$ & $20.1 \mathrm{e}$ & -4.9 & 14.4 & 11.1 & 11.7 & 7.6 & 11.3 & 11.7 & 3.7 \\
\hline Luxembourg & 4.2 & 5.4 & 12.6 & 11.8 & 14.8 & 10.5 & 6.0 & 0.8 & 6.9 & 11.8 & 4.2 & 12.9 & 8.3 & 3.3 \\
\hline Mexico & $-15.0 \mathrm{e}$ & $22.9 \mathrm{e}$ & $22.8 \mathrm{e}$ & $16.6 \mathrm{e}$ & $14.1 \mathrm{e}$ & $21.5 \mathrm{e}$ & $-1.6 \mathrm{e}$ & $1.5 \mathrm{e}$ & $0.7 \mathrm{e}$ & 10.7 & 8.5 & 12.6 & 7.0 & $4.3 \mathrm{e}$ \\
\hline Netherlands & 10.2 & 5.3 & 11.9 & 9.0 & 9.3 & 12.2 & 2.5 & 0.3 & 1.8 & 5.7 & 5.4 & 8.8 & 5.1 & 3.7 \\
\hline New Zealand & 6.8 & 6.4 & 2.5 & 2.1 & 11.3 & -0.7 & 4.0 & 7.2 & 12.7 & 12.5 & 4.2 & -1.6 & 9.6 & $2.0 \mathrm{e}$ \\
\hline Norway & 5.8 & 8.8 & 12.5 & 8.8 & -1.6 & 2.0 & 1.7 & 1.0 & 1.4 & 8.8 & 8.7 & 8.4 & 7.5 & 4.4 \\
\hline Poland & 24.2 & 28.0 & 21.4 & 18.6 & 1.0 & 15.5 & -5.3 & 2.8 & 9.6 & 15.8 & 4.7 & 17.4 & 13.7 & 8.0 \\
\hline Portugal & 7.4 & 5.2 & 9.8 & 14.2 & 8.6 & 5.3 & 0.9 & -0.7 & -0.8 & 6.7 & 3.5 & 5.1 & 6.2 & 2.7 \\
\hline Slovak Republic & 11.6 & 17.3 & 7.8 & 19.1 & 0.4 & 8.2 & 13.5 & 4.4 & 7.4 & 8.3 & 12.4 & 17.7 & 8.9 & 3.3 \\
\hline Spain & 11.1 & 8.8 & 13.3 & 14.9 & 13.7 & 10.8 & 4.5 & 3.7 & 6.2 & 9.6 & 7.7 & 10.2 & 8.0 & -4.9 \\
\hline Sweden & 7.1 & 3.3 & 12.4 & 11.2 & 5.1 & 11.6 & -1.8 & -1.3 & 3.8 & 6.8 & 7.0 & 8.7 & 9.4 & 3.0 \\
\hline Switzerland & 4.0 & 4.0 & 8.1 & 7.4 & 4.2 & 10.3 & 2.3 & -1.1 & 1.3 & 7.3 & 6.6 & 6.5 & 6.0 & 0.4 \\
\hline Turkey & $29.6 \mathrm{e}$ & $20.5 \mathrm{e}$ & $22.4 \mathrm{e}$ & 2.3 & -3.7 & 21.8 & -24.8 & 20.9 & 23.5 & 20.8 & 12.2 & 6.9 & 10.7 & -3.8 \\
\hline United Kingdom & 5.5 & 9.7 & 9.7 & 9.3 & 7.9 & 9.0 & 4.8 & 4.9 & 2.2 & 6.9 & 7.1 & 9.6 & -1.5 & -0.6 \\
\hline United States & 8.0 & 8.7 & 13.5 & 11.7 & 11.5 & 13.0 & -2.8 & 3.4 & 4.4 & 11.1 & 6.1 & 6.1 & 2.0 & -3.2 \\
\hline Euro area & .. & 3.7 & 9.2 & 10.4 & 7.9 & 11.6 & 2.3 & 0.4 & 3.2 & 7.0 & 5.7 & 8.3 & 5.3 & 1.1 \\
\hline OECD-Total &.. & $8.1 \mathrm{e}$ & $10.9 \mathrm{e}$ & $8.1 \mathrm{e}$ & $9.0 \mathrm{e}$ & $12.2 \mathrm{e}$ & $-0.1 \mathrm{e}$ & $2.9 \mathrm{e}$ & $4.5 \mathrm{e}$ & 9.2 & 6.4 & 8.2 & 5.1 & $0.6 \mathrm{e}$ \\
\hline
\end{tabular}

Figure 13.2. Imports of goods and services, volume

Annual growth rates in percentage, 2008

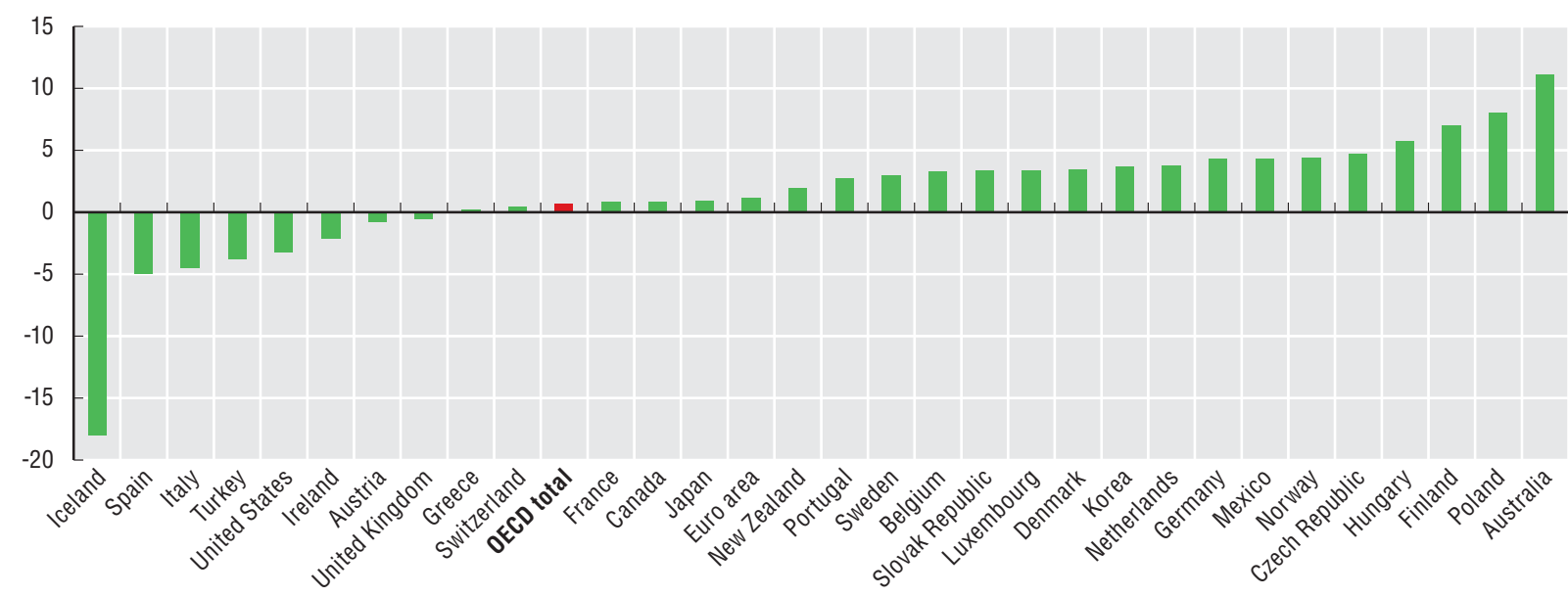

StatLink sils http://dx.doi.org/10.1787/740062232181 


\section{EXPENDITURE}

13. Fxports and imports of goods and services

Table 13.3. Terms of trade

Ratio of export prices to import prices

\begin{tabular}{|c|c|c|c|c|c|c|c|c|c|c|c|c|c|c|}
\hline & 1995 & 1996 & 1997 & 1998 & 1999 & 2000 & 2001 & 2002 & 2003 & 2004 & 2005 & 2006 & 2007 & 2008 \\
\hline Australia & 94.8 & 97.6 & 97.5 & 92.8 & 97.5 & 100.0 & 101.9 & 104.0 & 111.0 & 122.0 & 135.3 & 144.4 & 152.0 & $173.0 \mathrm{e}$ \\
\hline Austria & 104.2 & 102.4 & 101.6 & 101.4 & 101.5 & 100.0 & 100.3 & 101.7 & 101.9 & 101.7 & 100.9 & 100.0 & 99.6 & 98.0 \\
\hline Belgium & 103.6 & 102.6 & 101.9 & 102.7 & 102.0 & 100.0 & 100.1 & 100.8 & 100.6 & 100.2 & 99.9 & 99.2 & 99.6 & 96.8 \\
\hline Canada & 97.8 & 99.4 & 98.8 & 95.0 & 96.2 & 100.0 & 98.4 & 96.0 & 101.5 & 106.0 & 109.9 & 110.5 & 114.0 & $119.2 \mathrm{e}$ \\
\hline Czech Republic & 94.6 & 97.4 & 97.8 & 103.4 & 102.8 & 100.0 & 102.4 & 105.6 & 106.2 & 107.6 & 105.8 & 104.5 & 105.8 & 104.1 \\
\hline Denmark & 97.3 & 98.8 & 99.1 & 99.1 & 99.1 & 100.0 & 100.0 & 101.3 & 102.2 & 103.5 & 105.5 & 105.3 & 104.0 & 105.3 \\
\hline Finland & 107.2 & 106.8 & 105.3 & 107.3 & 104.1 & 100.0 & 101.6 & 102.0 & 100.5 & 98.1 & 94.7 & 91.7 & 90.4 & 87.4 \\
\hline France & 100.7 & 100.8 & 101.5 & 102.9 & 103.0 & 100.0 & 100.6 & 103.3 & 103.1 & 102.4 & 101.4 & 100.7 & 101.4 & 100.2 \\
\hline Germany & 105.9 & 105.1 & 102.8 & 104.5 & 105.1 & 100.0 & 99.9 & 101.9 & 102.9 & 102.6 & 101.2 & 99.8 & 100.2 & 99.4 \\
\hline Greece & $99.3 \mathrm{e}$ & $99.9 \mathrm{e}$ & $100.7 \mathrm{e}$ & $101.0 \mathrm{e}$ & $101.2 \mathrm{e}$ & 100.0 & 100.9 & 102.4 & 104.4 & 104.7 & 104.0 & 103.5 & 103.4 & 103.0 \\
\hline Hungary & 101.3 & 100.1 & 102.0 & 103.0 & 102.3 & 100.0 & 100.6 & 102.0 & 101.8 & 101.7 & 100.1 & 98.7 & 99.0 & 98.4 \\
\hline Iceland & 99.2 & 96.1 & 98.0 & 103.1 & 102.5 & 100.0 & 100.3 & 100.9 & 96.8 & 95.5 & 96.5 & 99.8 & 99.9 & 94.4 \\
\hline Ireland & 100.4 & 100.6 & 101.0 & 101.2 & 101.0 & 100.0 & 100.8 & 101.5 & 100.5 & 99.8 & 98.8 & 97.7 & 95.3 & 94.0 \\
\hline Italy & 100.8 & 103.8 & 103.4 & 106.5 & 106.5 & 100.0 & 100.8 & 102.6 & 104.4 & 104.3 & 102.0 & 99.1 & 100.4 & 98.7 \\
\hline Japan & 112.2 & 107.2 & 102.5 & 106.3 & 105.9 & 100.0 & 99.8 & 99.5 & 96.9 & 93.0 & 87.1 & 81.0 & 77.3 & $70.0 \mathrm{e}$ \\
\hline Korea & $131.5 \mathrm{e}$ & $123.7 \mathrm{e}$ & $116.2 \mathrm{e}$ & $113.9 \mathrm{e}$ & $110.5 \mathrm{e}$ & 100.0 & 97.4 & 97.4 & 96.5 & 93.8 & 90.4 & 87.2 & 86.5 & 79.9 \\
\hline Luxembourg & 103.9 & 104.8 & 101.2 & 100.1 & 102.3 & 100.0 & 99.2 & 100.1 & 104.4 & 103.2 & 103.5 & 106.0 & 105.8 & 107.6 \\
\hline Mexico & $91.8 \mathrm{e}$ & $93.1 \mathrm{e}$ & $96.2 \mathrm{e}$ & $93.9 \mathrm{e}$ & $96.8 \mathrm{e}$ & $100.0 \mathrm{e}$ & $100.5 \mathrm{e}$ & $101.8 \mathrm{e}$ & $100.6 \mathrm{e}$ & $99.1 \mathrm{e}$ & $101.9 \mathrm{e}$ & $104.3 \mathrm{e}$ & $104.5 \mathrm{e}$ & $105.3 \mathrm{e}$ \\
\hline Netherlands & 98.5 & 98.6 & 99.6 & 100.1 & 99.8 & 100.0 & 101.3 & 102.3 & 102.4 & 101.6 & 102.4 & 102.0 & 101.6 & 101.8 \\
\hline New Zealand & 101.7 & 102.7 & 100.7 & 99.3 & 99.5 & 100.0 & 103.1 & 101.5 & 107.9 & 111.8 & 110.4 & 108.7 & 118.1 & $120.2 \mathrm{e}$ \\
\hline Norway & 71.6 & 75.9 & 77.2 & 70.2 & 78.6 & 100.0 & 97.9 & 92.6 & 93.5 & 100.7 & 116.4 & 130.3 & 128.2 & 143.8 \\
\hline Poland & 109.5 & 106.7 & 105.2 & 107.3 & 106.0 & 100.0 & 100.0 & 99.3 & 98.9 & 102.2 & 103.3 & 103.2 & 105.0 & 103.1 \\
\hline Portugal & 100.6 & 98.2 & 98.9 & 101.9 & 103.0 & 100.0 & 100.5 & 102.1 & 102.5 & 101.8 & 100.4 & 100.7 & 102.0 & 100.3 \\
\hline Slovak Republic & 101.4 & 96.7 & 101.1 & 98.6 & 97.3 & 100.0 & 98.9 & 98.9 & 98.5 & 98.3 & 98.1 & 96.8 & 95.7 & 94.2 \\
\hline Spain & 100.9 & 101.8 & 101.3 & 103.4 & 103.0 & 100.0 & 102.1 & 104.9 & 106.3 & 105.6 & 106.2 & 106.5 & 107.0 & 105.2 \\
\hline Sweden & 106.1 & 105.2 & 104.8 & 104.1 & 101.6 & 100.0 & 98.7 & 97.0 & 97.1 & 95.8 & 94.2 & 93.9 & 95.9 & 95.8 \\
\hline Switzerland & 106.0 & 105.2 & 102.1 & 103.5 & 102.8 & 100.0 & 99.8 & 103.5 & 105.5 & 104.8 & 102.3 & 101.2 & 100.9 & 100.4 \\
\hline Turkey & $108.3 \mathrm{e}$ & $101.5 \mathrm{e}$ & $109.0 \mathrm{e}$ & 107.4 & 110.3 & 100.0 & 97.9 & 100.6 & 104.0 & 106.3 & 106.0 & 101.2 & 103.2 & 100.8 \\
\hline United Kingdom & 94.3 & 95.8 & 98.8 & 99.8 & 101.2 & 100.0 & 99.8 & 102.4 & 103.8 & 104.0 & 101.0 & 101.0 & 102.6 & 104.0 \\
\hline United States & 98.2 & 98.7 & 100.5 & 103.8 & 102.5 & 100.0 & 102.1 & 102.8 & 101.5 & 100.2 & 97.8 & 97.1 & 97.0 & 91.9 \\
\hline Euro area & 102.3 & 102.5 & 101.9 & 103.4 & 103.4 & 100.0 & 100.6 & 102.3 & 102.8 & 102.3 & 101.3 & 100.1 & 100.3 & 99.0 \\
\hline OECD-Total & $100.9 \mathrm{e}$ & $100.8 \mathrm{e}$ & $101.1 \mathrm{e}$ & $102.5 \mathrm{e}$ & $102.3 \mathrm{e}$ & $100.0 \mathrm{e}$ & $100.7 \mathrm{e}$ & $101.7 \mathrm{e}$ & $101.9 \mathrm{e}$ & $101.5 \mathrm{e}$ & $100.4 \mathrm{e}$ & $99.4 \mathrm{e}$ & $99.5 \mathrm{e}$ & $97.3 \mathrm{e}$ \\
\hline
\end{tabular}

StatLink लोड़ी http://dx.doi.org/10.1787/741003457543

\section{Figure 13.3. Terms of trade}

Ratio of export prices to import prices, 2008

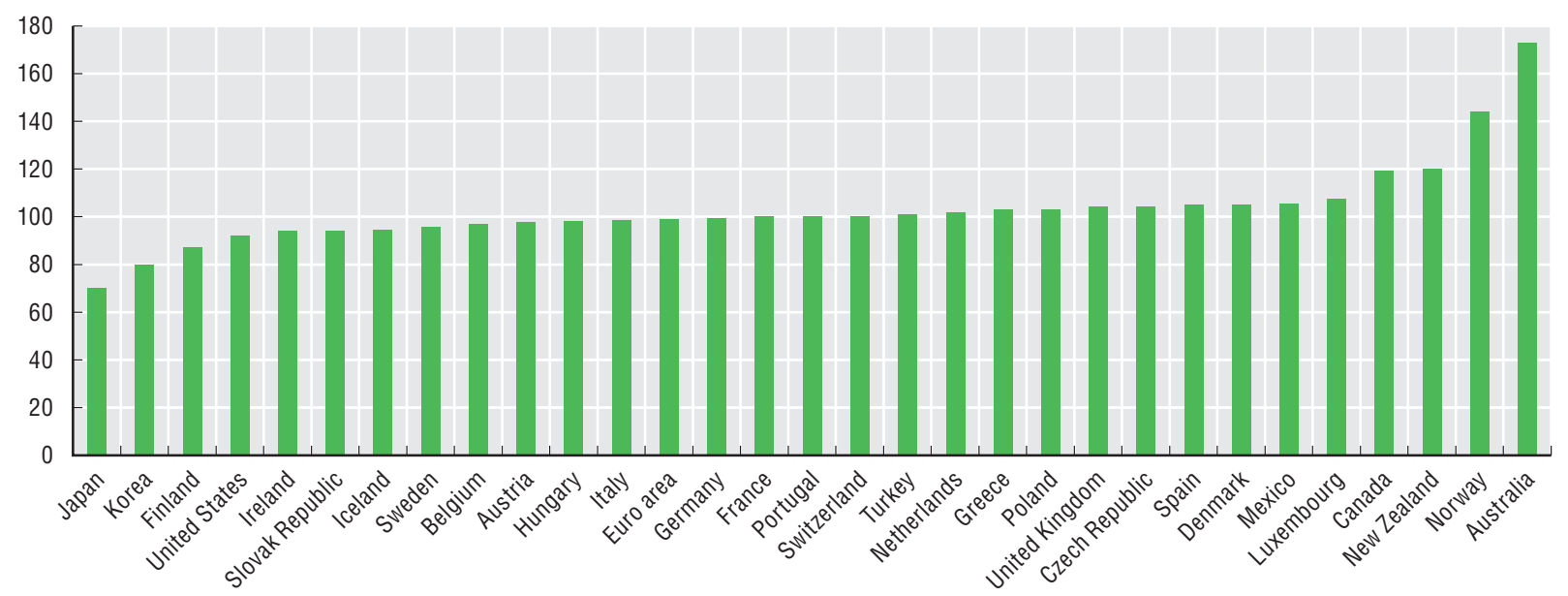

StatLink AाsL http://dx.doi.org/10.1787/740073114683 



\section{Value added}

Value added reflects the contribution of labour and capital to production. It can be shown by: type of enterprise/establishment (activity, size, market/nonmarket, age, etc.); type of product, and institutional sector and combinations of these, and is a key variable in economic analyses such as productivity and structural analysis.

\section{Definition}

Value added at basic prices can be simply defined as the difference between gross output (at basic prices) and intermediate consumption (at purchasers prices) and can be decomposed into the following components: Compensation of Employees; Gross Operating Surplus; Mixed Income; and Other Taxes on Production less Subsidies on Production. It can also be derived as the difference between GDP (at market prices) and taxes on products less subsidies on products.

The SNA recommends the basic price valuation for value added but it can also be measured on different price bases such as producers prices and at factor cost.

One of the major advantages of value added is that it avoids problems inherent in the measurement of output which is a gross concept - gross in the sense that it counts the output of all production units. Countries with fragmented production networks therefore will have, all other things equal, higher output than those with more consolidated networks, complicating international comparisons. Indeed this is also a temporal problem as production networks can become more or less consolidated (through outsourcing for example) within a country from one year to another. Indeed production networks have become increasingly globalised in recent years, further affecting temporal and cross-country comparability.

Value added avoids these problems by measuring the value that a resident unit adds to that of the resident units that supply its inputs.

Like its GDP counterpart, value added can also be measured on a net basis, where the "net" refers to net of depreciation.

Like its nominal counterpart, real value added can be derived as the difference between real output and real intermediate consumption, an approach known as double-deflation.

A useful additional comment worth making in the context of value added concerns non-market output.
By convention, because market prices are not observable, non-market output is calculated on a sum of costs approach with value added set equal to depreciation only and no net return to capital imputed.

\section{Comparability}

All countries produce statistics on value added on the basis of the 1993 SNA, however, not all produce value added on the basis of basic prices.

The tables and figures showing breakdowns by activity are based on the ISIC Rev. 3 industrial classification system. Countries generally collect information using their own industrial classification systems. The conversion from a national classification system to ISIC may create some comparability issues. For example, for Japan, Hotels (which form approximately 2.8-3.0 \% of value added) are included in Other Services not Wholesale, Retail, etc. That said, at the 6 activity level presented here, for most countries the sectors are generally comparable.

Japan uses approximately market prices. New Zealand uses producer prices, and Iceland and the USA use factor costs.

\section{Source}

- OECD (2009), National Accounts of OECD Countries 2009, Volume I, Main Aggregates, OECD Publishing, http://dx.doi.org/10.1787/na_vol_1-2009-en-fr.

\section{Online database}

- OECD (2009), "Aggregate national accounts: gross domestic product", OECD National Accounts Statistics (database), http://dx.doi.org/10.1787/data-00001-en.

- OECD (2009), "Detailed national accounts: Value added and its components by activity", OECD National Accounts Statistics (database), http://dx.doi.org/10.1787/data-00006-en.

\section{Further reading}

- Lequiller, F. and D. Blades (2007), Understanding National Accounts, OECD Publishing, http://dx.doi.org/10.1787/9789264027657-en.

- OECD (2000), System of National Accounts, 1993 Glossary, OECD Publishing, http://dx.doi.org/10.1787/9789264180871-en.

- UN, OECD, IMF, Eurostat (eds.) (1993), System of National Accounts 1993, United Nations, Geneva, http://unstats.un.org/unsd/sna1993. 
Table 14.1. Gross value added at basic prices, volume

\begin{tabular}{|c|c|c|c|c|c|c|c|c|c|c|c|c|c|c|}
\hline & 1995 & 1996 & 1997 & 1998 & 1999 & 2000 & 2001 & 2002 & 2003 & 2004 & 2005 & 2006 & 2007 & 2008 \\
\hline Australia & 4.3 & 4.1 & 4.2 & 5.3 & 4.1 & 2.3 & 3.7 & 2.9 & 4.1 & 2.9 & 3.0 & 3.4 & 3.9 & .. \\
\hline Austria & 3.1 & 1.8 & 2.9 & 3.5 & 3.0 & 3.6 & 0.7 & 1.7 & 1.0 & 2.7 & 2.6 & 3.8 & 3.6 & 2.3 \\
\hline Belgium & 3.1 & 0.8 & 3.3 & 1.6 & 3.1 & 3.6 & 1.3 & 1.4 & 1.2 & 2.4 & 1.9 & 2.9 & 2.7 & 1.3 \\
\hline Canada & $2.6 \mathrm{e}$ & $1.4 \mathrm{e}$ & 4.2 & 3.9 & 5.6 & 5.5 & 1.6 & 2.6 & 2.1 & 3.3 & 3.0 & 2.9 &.. & .. \\
\hline Czech Republic & 5.1 & 3.5 & -1.6 & -0.7 & 1.5 & 3.8 & 2.5 & 2.5 & 2.9 & 4.5 & 6.6 & 7.6 & 5.9 & 3.4 \\
\hline Denmark & 3.2 & 2.4 & 3.0 & 1.9 & 2.9 & 4.4 & 0.7 & 0.3 & 0.4 & 1.5 & 1.5 & 3.0 & 1.7 & -0.9 \\
\hline Finland & 3.9 & 3.8 & 6.0 & 5.0 & 4.1 & 5.7 & 2.9 & 1.2 & 0.9 & 3.6 & 2.7 & 5.1 & 4.5 & 0.9 \\
\hline France & 2.3 & 1.2 & 2.4 & 3.5 & 3.2 & 3.7 & 1.8 & 1.0 & 1.0 & 2.6 & 1.8 & 2.2 & 2.4 & 0.7 \\
\hline Germany & 2.2 & 1.3 & 1.9 & 2.1 & 1.9 & 3.7 & 1.5 & 0.3 & -0.2 & 1.6 & 0.9 & 3.1 & 2.9 & 1.4 \\
\hline Greece & $2.0 \mathrm{e}$ & $1.8 \mathrm{e}$ & $3.3 \mathrm{e}$ & $3.9 \mathrm{e}$ & $2.1 \mathrm{e}$ & $4.4 \mathrm{e}$ & 3.6 & 4.1 & 6.4 & 5.4 & 2.3 & 3.2 & 4.3 & 2.0 \\
\hline Hungary & 0.6 & 2.5 & 4.5 & 5.4 & 4.2 & 4.3 & 3.9 & 4.0 & 4.0 & 5.2 & 3.4 & 4.2 & 0.8 & 0.9 \\
\hline Iceland & 1.5 & 6.0 & 4.8 & 6.1 & 5.2 & 6.1 & 4.4 & -0.8 & 3.7 & 7.3 & 8.8 &.. &.. & .. \\
\hline Ireland &.. & 8.4 & 10.9 & 8.5 & 9.2 & 8.6 & 7.2 & 6.3 & 3.7 & 5.2 & 5.3 & 5.3 & 7.1 & .. \\
\hline Italy & 2.8 & 1.1 & 1.6 & 1.2 & 1.2 & 3.7 & 1.8 & 0.6 & -0.3 & 1.7 & 0.8 & 2.0 & 1.7 & -0.9 \\
\hline Japan & $2.3 \mathrm{e}$ & 3.1 & 1.7 & -1.7 & 0.2 & 2.2 & 0.1 & 0.8 & 1.4 & 2.0 & 2.4 & 1.4 & 1.1 & .. \\
\hline Korea & $8.6 \mathrm{e}$ & $6.4 \mathrm{e}$ & $4.8 \mathrm{e}$ & $-5.7 \mathrm{e}$ & $8.7 \mathrm{e}$ & $8.1 \mathrm{e}$ & 4.0 & 7.2 & 3.0 & 4.7 & 4.0 & 5.1 & 5.4 & 2.4 \\
\hline Luxembourg & 2.6 & 1.5 & 5.2 & 6.4 & 8.1 & 7.5 & 3.3 & 4.0 & 1.4 & 3.9 & 5.6 & 6.1 & 6.6 & -0.1 \\
\hline Mexico & $-6.3 \mathrm{e}$ & $4.9 \mathrm{e}$ & $6.9 \mathrm{e}$ & $5.0 \mathrm{e}$ & $3.8 \mathrm{e}$ & $6.6 \mathrm{e}$ & $0.2 \mathrm{e}$ & $1.0 \mathrm{e}$ & $1.6 \mathrm{e}$ & 4.2 & 3.6 & 5.4 & 3.5 & .. \\
\hline Netherlands & 3.0 & 3.0 & 4.2 & 3.8 & 4.6 & 4.0 & 1.9 & 0.2 & 0.5 & 2.3 & 2.1 & 3.3 & 3.7 & 2.2 \\
\hline New Zealand & 4.3 & 3.7 & 2.0 & 0.5 & 5.4 & 2.5 & 3.8 & 4.8 & 4.0 & 3.9 & 3.0 & 1.9 & 3.3 & .. \\
\hline Norway & 3.9 & 4.7 & 5.4 & 2.4 & 2.0 & 3.3 & 1.7 & 1.2 & 1.0 & 3.2 & 2.4 & 1.6 & 2.6 & 2.5 \\
\hline Poland & 6.7 & 5.7 & 6.5 & 4.8 & 4.3 & 4.0 & 1.3 & 1.3 & 3.6 & 5.2 & 3.3 & 6.0 & 6.7 & 5.0 \\
\hline Portugal & 3.7 & 3.5 & 4.1 & 4.1 & 3.2 & 3.9 & 2.4 & 0.8 & -0.4 & 1.7 & 0.8 & 1.6 & 2.0 & 0.4 \\
\hline Slovak Republic & 5.4 & 7.2 & 5.6 & 3.0 & 0.3 & 0.5 & 4.9 & 4.4 & 3.7 & 4.6 & 5.7 & 10.1 & 10.4 & 7.2 \\
\hline Spain & 2.6 & 2.3 & 3.7 & 4.2 & 4.5 & 5.1 & 3.7 & 2.6 & 2.7 & 3.2 & 3.3 & 4.1 & 3.9 & 1.1 \\
\hline Sweden & 4.8 & 1.6 & 2.8 & 3.8 & 4.6 & 4.9 & 0.9 & 2.3 & 1.9 & 4.4 & 3.2 & 4.4 & 2.6 & -0.1 \\
\hline Switzerland & 0.3 & 0.6 & 1.6 & 2.6 & 0.7 & 3.3 & 1.1 & 0.6 & -0.3 & 2.5 & 2.6 & 3.6 & 3.7 & 1.8 \\
\hline Turkey & $6.9 \mathrm{e}$ & $6.3 \mathrm{e}$ & $6.9 \mathrm{e}$ & 3.4 & -3.0 & 6.6 & -4.5 & 5.2 & 4.5 & 9.6 & 8.5 & 7.5 & 4.8 & 1.5 \\
\hline United Kingdom & 2.9 & 3.0 & 3.4 & 3.9 & 3.6 & 3.8 & 2.3 & 1.8 & 2.8 & 2.8 & 2.2 & 3.0 & 2.8 & 0.7 \\
\hline United States & $3.3 \mathrm{e}$ & $3.9 \mathrm{e}$ & $5.0 \mathrm{e}$ & $5.1 \mathrm{e}$ & $4.6 \mathrm{e}$ & $3.8 \mathrm{e}$ & $0.9 \mathrm{e}$ & $1.3 \mathrm{e}$ & $2.5 \mathrm{e}$ & $3.5 \mathrm{e}$ & $3.2 \mathrm{e}$ & $2.7 \mathrm{e}$ & $2.0 \mathrm{e}$ & .. \\
\hline Euro area &.. & 1.6 & 2.6 & 2.8 & 2.7 & 4.0 & 2.0 & 1.0 & 0.7 & 2.3 & 1.7 & 3.0 & 3.0 & 0.9 \\
\hline OECD-Total &.. & $3.1 \mathrm{e}$ & $3.7 \mathrm{e}$ & $2.9 \mathrm{e}$ & $3.3 \mathrm{e}$ & $3.9 \mathrm{e}$ & $1.2 \mathrm{e}$ & $1.5 \mathrm{e}$ & $1.9 \mathrm{e}$ & $3.1 \mathrm{e}$ & $2.8 \mathrm{e}$ & .. &.. & .. \\
\hline
\end{tabular}

Figure 14.1. Gross value added at basic prices, volume

Average annual growth rates in percentage

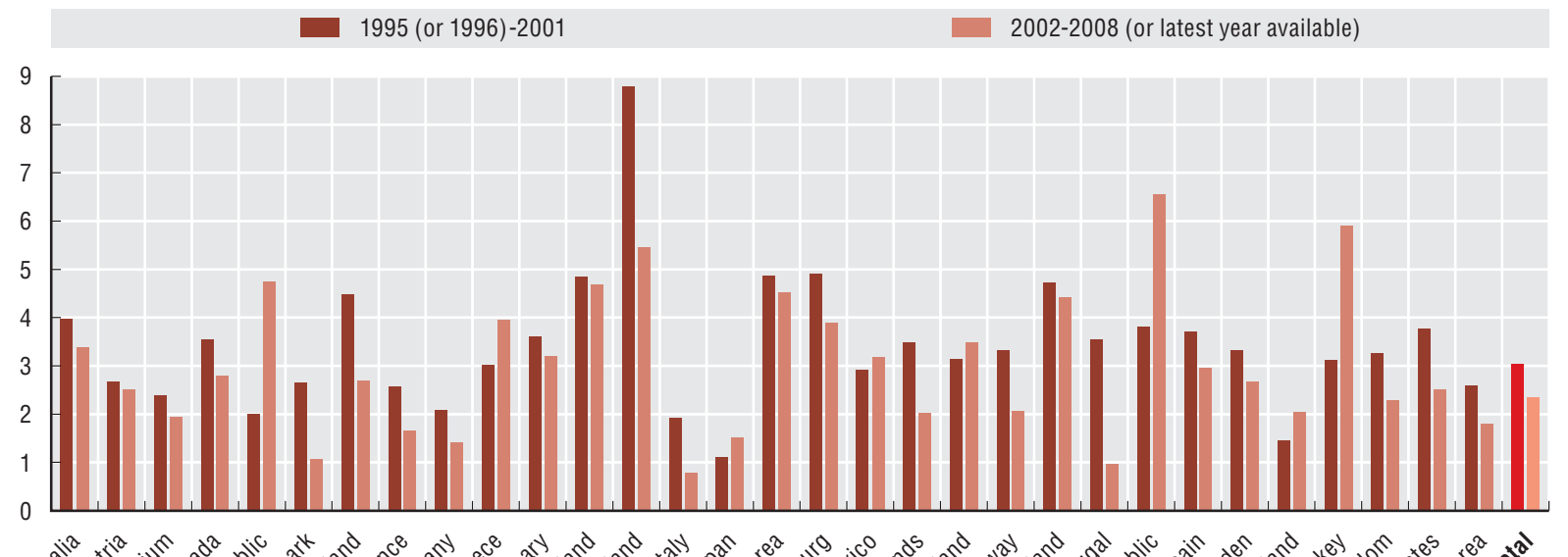

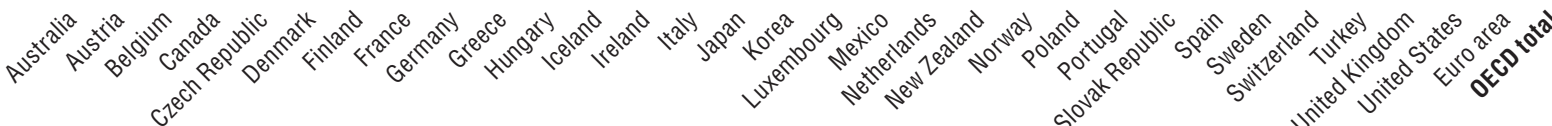




\section{Value added}

Table 14.2. Gross value added by activity

Percentage of total activity

\begin{tabular}{|c|c|c|c|c|c|c|c|c|c|c|c|c|}
\hline & \multicolumn{2}{|c|}{$\begin{array}{l}\text { Agriculture, hunting and } \\
\text { foresty; fishing }\end{array}$} & \multicolumn{2}{|c|}{ Industry, including energy } & \multicolumn{2}{|c|}{ Construction } & \multicolumn{2}{|c|}{$\begin{array}{l}\text { Wholesale and retail trade, } \\
\text { repairs; hotels and restaurants; } \\
\text { transport }\end{array}$} & \multicolumn{2}{|c|}{$\begin{array}{l}\text { Financial intermediation; real } \\
\text { estate, renting and business } \\
\text { activities }\end{array}$} & \multicolumn{2}{|c|}{ Other service activities } \\
\hline & 1997 & 2007 & 1997 & 2007 & 1997 & 2007 & 1997 & 2007 & 1997 & 2007 & 1997 & 2007 \\
\hline Australia & 3.4 & 2.6 & 21.7 & 21.2 & 6.0 & 7.9 & 23.2 & 20.2 & 27.3 & 29.8 & 18.4 & 18.4 \\
\hline Austria & 2.3 & 1.8 & 23.0 & 23.1 & 7.9 & 7.3 & 24.7 & 23.2 & 20.3 & 24.3 & 21.8 & 20.4 \\
\hline Belgium & 1.6 & 0.8 & 23.4 & 18.7 & 4.9 & 5.3 & 21.3 & 22.9 & 26.2 & 29.0 & 22.5 & 23.3 \\
\hline Canada & 2.5 & .. & 25.6 & .. & 5.3 & .. & 21.0 & .. & 25.2 & .. & 20.4 & .. \\
\hline Czech Republic & 4.2 & 2.5 & 33.0 & 32.0 & 7.5 & 6.4 & 24.7 & 24.9 & 14.8 & 17.5 & 15.8 & 16.7 \\
\hline Denmark & 3.2 & 1.2 & 20.9 & 20.3 & 4.8 & 6.1 & 22.5 & 21.3 & 21.8 & 24.6 & 26.8 & 26.4 \\
\hline Finland & 4.0 & 3.2 & 27.4 & 26.2 & 4.9 & 6.4 & 21.8 & 21.6 & 19.3 & 21.1 & 22.7 & 21.4 \\
\hline France & 3.2 & 2.2 & 18.4 & 14.1 & 5.1 & 6.3 & 19.1 & 18.8 & 29.4 & 33.4 & 24.8 & 25.2 \\
\hline Germany & 1.3 & 1.0 & 25.1 & 26.1 & 6.0 & 4.1 & 17.8 & 17.4 & 27.3 & 29.4 & 22.6 & 22.1 \\
\hline Greece & $7.7 \mathrm{e}$ & 3.8 & $13.8 \mathrm{e}$ & 13.6 & $6.2 \mathrm{e}$ & 6.0 & $29.7 \mathrm{e}$ & 33.5 & $21.0 \mathrm{e}$ & 18.8 & $21.5 \mathrm{e}$ & 24.3 \\
\hline Hungary & 7.0 & 4.0 & 27.2 & 25.2 & 4.5 & 4.6 & 21.5 & 21.4 & 18.4 & 22.5 & 21.5 & 22.3 \\
\hline Iceland & 9.8 & .. & 20.6 &.. & 8.3 & .. & 21.7 & .. & 17.7 & .. & 21.9 & .. \\
\hline Ireland & 5.2 & 1.7 & 33.1 & 23.7 & 5.6 & 9.9 & 18.6 & 18.0 & 18.7 & 28.1 & 18.9 & 18.7 \\
\hline Italy & 3.2 & 2.0 & 24.4 & 21.4 & 5.1 & 6.1 & 23.9 & 22.5 & 22.8 & 27.3 & 20.6 & 20.6 \\
\hline Japan & 1.7 & 1.4 & 25.0 & 22.6 & 7.8 & 5.9 & 21.2 & 19.4 & 23.4 & 27.0 & 20.9 & 23.6 \\
\hline Korea & $5.2 \mathrm{e}$ & 2.9 & $28.0 \mathrm{e}$ & 30.0 & $10.2 \mathrm{e}$ & 7.4 & $18.2 \mathrm{e}$ & 17.8 & $21.0 \mathrm{e}$ & 21.6 & $16.7 \mathrm{e}$ & 20.4 \\
\hline Luxembourg & 0.8 & 0.4 & 14.7 & 10.5 & 6.2 & 5.5 & 23.2 & 19.8 & 37.8 & 48.6 & 17.3 & 15.2 \\
\hline Mexico & $5.7 \mathrm{e}$ & 3.4 & $31.0 \mathrm{e}$ & 28.5 & $5.5 \mathrm{e}$ & 7.0 & $29.2 \mathrm{e}$ & 28.0 & $20.8 \mathrm{e}$ & 20.2 & $11.4 \mathrm{e}$ & 12.9 \\
\hline Netherlands & 3.5 & 2.1 & 20.6 & 19.0 & 5.3 & 5.5 & 22.3 & 21.9 & 26.0 & 28.0 & 22.4 & 23.6 \\
\hline New Zealand & 6.8 & .. & 21.0 & .. & 4.5 & .. & 23.1 & .. & 27.4 & .. & 17.1 & .. \\
\hline Norway & 2.4 & 1.4 & 32.5 & 37.7 & 4.6 & 5.0 & 21.4 & 17.5 & 16.8 & 17.9 & 22.2 & 20.4 \\
\hline Poland & 6.6 & 4.3 & 26.2 & 24.5 & 7.2 & 7.1 & 26.4 & 26.5 & 15.3 & 19.0 & 18.2 & 18.5 \\
\hline Portugal & 4.6 & 2.5 & 22.0 & 18.0 & 7.0 & 6.5 & 24.2 & 24.3 & 19.7 & 22.3 & 22.5 & 26.4 \\
\hline Slovak Republic & 5.3 & 3.6 & 28.0 & 31.3 & 7.3 & 7.9 & 26.3 & 24.5 & 17.0 & 16.9 & 16.2 & 15.8 \\
\hline Spain & 5.0 & 2.7 & 22.2 & 17.4 & 7.1 & 11.8 & 26.4 & 24.5 & 18.4 & 22.6 & 21.0 & 21.0 \\
\hline Sweden & 2.5 & 1.4 & 25.0 & 23.4 & 4.0 & 4.9 & 19.0 & 19.1 & 24.2 & 24.8 & 25.1 & 26.3 \\
\hline Switzerland & 1.8 & 1.2 & 23.0 & 22.2 & 5.4 & 5.4 & 22.0 & 21.6 & 21.8 & 24.3 & 26.0 & 25.3 \\
\hline Turkey & $10.8 \mathrm{e}$ & 8.5 & $31.0 \mathrm{e}$ & 22.3 & $6.2 \mathrm{e}$ & 5.4 & $29.9 \mathrm{e}$ & 31.8 & $13.2 \mathrm{e}$ & 20.3 & $9.2 \mathrm{e}$ & 11.6 \\
\hline United Kingdom & 1.4 & 0.6 & 24.9 & 16.7 & 5.0 & 6.4 & 21.9 & 21.1 & 25.4 & 32.1 & 21.4 & 23.1 \\
\hline United States & 1.7 & 1.3 & 21.1 & 17.1 & 4.3 & 4.7 & 22.4 & 19.0 & 27.8 & 33.0 & 22.6 & 24.9 \\
\hline Euro area & 2.8 & 1.9 & 22.8 & 20.4 & 5.7 & 6.4 & 21.0 & 20.8 & 25.2 & 28.2 & 22.5 & 22.4 \\
\hline OECD-Total & $2.7 \mathrm{e}$ & .. & $23.5 \mathrm{e}$ & .. & $5.6 \mathrm{e}$ & .. & $22.2 \mathrm{e}$ & .. & $25.0 \mathrm{e}$ & .. & $21.2 \mathrm{e}$ & .. \\
\hline
\end{tabular}

StatLink ला15स http://dx.doi.org/10.1787/741132223264

Figure 14.2. Gross value added by activity

Percentage of total activity, 2007

Agriculture, hunting and forestry; fishing

Construction

Financial intermediation; real estate, renting and business activities
Industry, including energy

Wholesale and retail trade, repairs; hotels and restaurants; transport Other service activities

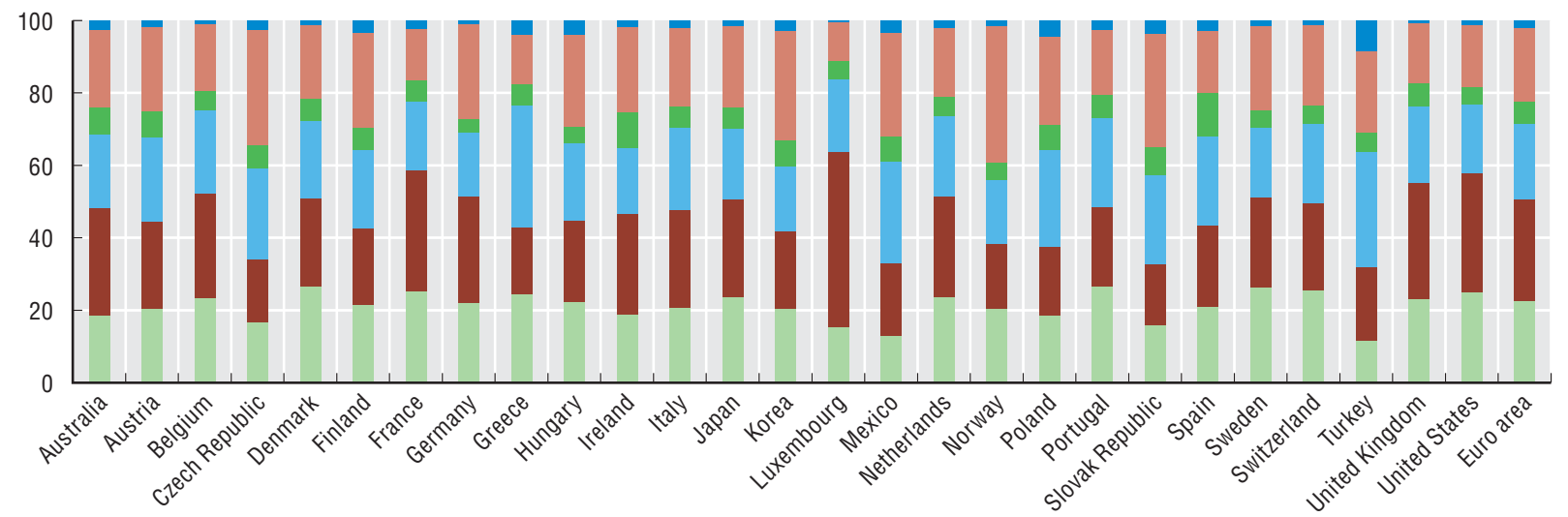

StatLink Aाs< http://dx.doi.org/10.1787/740125325457 
Table 14.3. Contribution to gross value added growth by activity

\begin{tabular}{|c|c|c|c|c|c|c|c|c|c|c|c|c|}
\hline \multicolumn{13}{|c|}{ Percentage } \\
\hline & \multicolumn{2}{|c|}{$\begin{array}{l}\text { Agriculture, hunting and } \\
\text { foresty; fishing }\end{array}$} & \multicolumn{2}{|c|}{ Industry, including energy } & \multicolumn{2}{|c|}{ Construction } & \multicolumn{2}{|c|}{$\begin{array}{c}\text { Wholesale and retail trade, } \\
\text { repairs; hotels and restaurants; } \\
\text { transport }\end{array}$} & \multicolumn{2}{|c|}{$\begin{array}{l}\text { Financial intermediation; real } \\
\text { estate, renting and business } \\
\text { activities }\end{array}$} & \multicolumn{2}{|c|}{ Other service activities } \\
\hline & 1997 & 2007 & 1997 & 2007 & 1997 & 2007 & 1997 & 2007 & 1997 & 2007 & 1997 & 2007 \\
\hline Australia & -0.0 & 0.2 & 0.7 & 0.5 & 0.6 & 0.5 & 1.1 & 0.9 & 1.4 & 1.3 & 0.4 & 0.5 \\
\hline Austria & -0.0 & 0.1 & 0.7 & 1.6 & -0.1 & 0.5 & 0.6 & 0.4 & 0.8 & 0.9 & 1.0 & 0.2 \\
\hline Belgium & 0.0 & 0.0 & 1.5 & 0.5 & 0.2 & 0.2 & 0.3 & 1.1 & 1.2 & 0.6 & 0.0 & 0.3 \\
\hline Canada & -0.1 & .. & 1.3 & .. & 0.3 & .. & 1.0 & .. & 1.4 & .. & 0.3 & .. \\
\hline Czech Republic & -0.6 & -0.3 & -0.3 & 2.3 & -1.5 & 0.3 & 1.8 & 1.8 & -0.5 & 1.8 & -0.5 & -0.1 \\
\hline Denmark & 0.1 & -0.3 & 1.5 & -0.1 & -0.1 & 0.2 & 0.2 & 0.7 & 1.0 & 0.8 & 0.4 & 0.4 \\
\hline Finland & 0.4 & 0.3 & 2.3 & 2.3 & 0.5 & 0.4 & 1.4 & 0.6 & 0.9 & 0.8 & 0.6 & 0.0 \\
\hline France & 0.0 & -0.0 & 0.6 & 0.1 & -0.2 & 0.2 & 1.0 & 0.7 & 0.6 & 1.1 & 0.3 & 0.3 \\
\hline Germany & 0.0 & -0.0 & 0.9 & 0.5 & -0.2 & 0.0 & 0.4 & 0.5 & 0.5 & 1.4 & 0.2 & 0.5 \\
\hline Greece & $0.0 \mathrm{e}$ & -0.3 & $-0.4 \mathrm{e}$ & 0.8 & $0.2 \mathrm{e}$ & -0.4 & $2.3 \mathrm{e}$ & 1.4 & $0.7 \mathrm{e}$ & 1.2 & $0.6 \mathrm{e}$ & 1.5 \\
\hline Hungary & -0.1 & -0.9 & 2.7 & 1.5 & 0.3 & -0.3 & 1.7 & 0.9 & -0.8 & 0.1 & 0.7 & -0.6 \\
\hline Iceland & -0.1 & .. & 0.9 & .. & 0.8 & .. & 1.4 & .. & 1.0 & .. & 0.8 & .. \\
\hline Ireland & 0.1 & 0.0 & 5.3 & 2.8 & 0.8 & 0.0 & 1.6 & 1.1 & 2.6 & 2.6 & 0.5 & 0.6 \\
\hline Italy & 0.1 & -0.0 & 0.2 & 0.4 & -0.1 & 0.0 & 0.4 & 0.5 & 0.6 & 0.7 & 0.3 & 0.2 \\
\hline Japan & -0.0 & 0.1 & 0.6 & 0.7 & -0.1 & -0.2 & 0.5 & 0.0 & 0.5 & 0.2 & 0.2 & 0.4 \\
\hline Korea & $0.3 \mathrm{e}$ & 0.1 & $1.5 \mathrm{e}$ & 2.0 & $0.3 \mathrm{e}$ & 0.2 & $1.0 \mathrm{e}$ & 0.9 & $1.2 \mathrm{e}$ & 1.2 & $0.6 \mathrm{e}$ & 1.0 \\
\hline Luxembourg & -0.2 & -0.0 & 0.8 & 0.8 & 0.3 & -0.0 & 1.4 & 1.1 & 2.6 & 4.2 & 0.3 & 0.5 \\
\hline Mexico & $0.0 \mathrm{e}$ & 0.2 & $2.8 \mathrm{e}$ & 0.6 & $0.5 \mathrm{e}$ & 0.3 & $3.0 \mathrm{e}$ & 1.3 & $0.9 \mathrm{e}$ & 0.9 & $0.4 \mathrm{e}$ & 0.2 \\
\hline Netherlands & 0.2 & 0.1 & -0.1 & 0.4 & 0.1 & 0.3 & 1.8 & 1.0 & 1.7 & 1.4 & 0.4 & 0.4 \\
\hline New Zealand & 0.0 & .. & -0.1 & .. & 0.2 & .. & 0.7 & .. & 0.6 & .. & 0.6 & .. \\
\hline Norway & -0.0 & 0.1 & 1.7 & -0.7 & 0.3 & 0.2 & 1.7 & 1.2 & 1.0 & 1.1 & 0.7 & 0.7 \\
\hline Poland & 0.0 & -0.2 & 2.6 & 2.5 & 0.8 & 0.7 & 1.7 & 1.1 & 1.0 & 2.0 & 0.3 & 0.5 \\
\hline Portugal & -0.5 & -0.1 & 1.4 & 0.6 & 0.6 & 0.0 & 1.2 & 0.6 & 1.0 & 0.7 & 0.3 & 0.2 \\
\hline Slovak Republic & 0.8 & 0.3 & -2.0 & 4.0 & -0.0 & 0.6 & 2.8 & 3.4 & 3.5 & 0.8 & 1.0 & 1.3 \\
\hline Spain & 0.4 & 0.0 & 1.2 & 0.2 & 0.2 & 0.3 & 0.7 & 1.0 & 0.7 & 1.4 & 0.5 & 0.9 \\
\hline Sweden & 0.0 & -0.0 & 1.8 & 0.6 & -0.2 & 0.2 & 0.8 & 0.6 & 0.5 & 1.1 & -0.1 & 0.1 \\
\hline Switzerland & -0.1 & 0.0 & 0.6 & 1.1 & -0.4 & -0.1 & 0.2 & 0.9 & 1.4 & 1.4 & -0.0 & 0.4 \\
\hline Turkey & $-0.3 e$ & -0.6 & $3.2 \mathrm{e}$ & 1.3 & $0.3 \mathrm{e}$ & 0.3 & $2.9 \mathrm{e}$ & 2.0 & $0.4 \mathrm{e}$ & 1.6 & $0.2 \mathrm{e}$ & 0.4 \\
\hline United Kingdom & 0.1 & -0.0 & 0.4 & 0.0 & 0.1 & 0.2 & 1.1 & 0.6 & 1.6 & 1.7 & 0.1 & 0.3 \\
\hline United States & 0.1 & 0.0 & 0.8 & 0.4 & 0.1 & -0.5 & 1.2 & 0.6 & 2.4 & 1.1 & 0.3 & 0.4 \\
\hline Euro area & 0.1 & 0.0 & 0.8 & 0.5 & -0.1 & 0.2 & 0.8 & 0.7 & 0.7 & 1.2 & 0.3 & 0.4 \\
\hline OECD-Total & $0.1 \mathrm{e}$ & .. & $1.0 \mathrm{e}$ & .. & $0.1 \mathrm{e}$ & & $1.2 \mathrm{e}$ & .. & $1.2 \mathrm{e}$ & & $0.3 \mathrm{e}$ & .. \\
\hline
\end{tabular}

Figure 14.3. Contribution to gross value added growth by activity Percentage, 2007

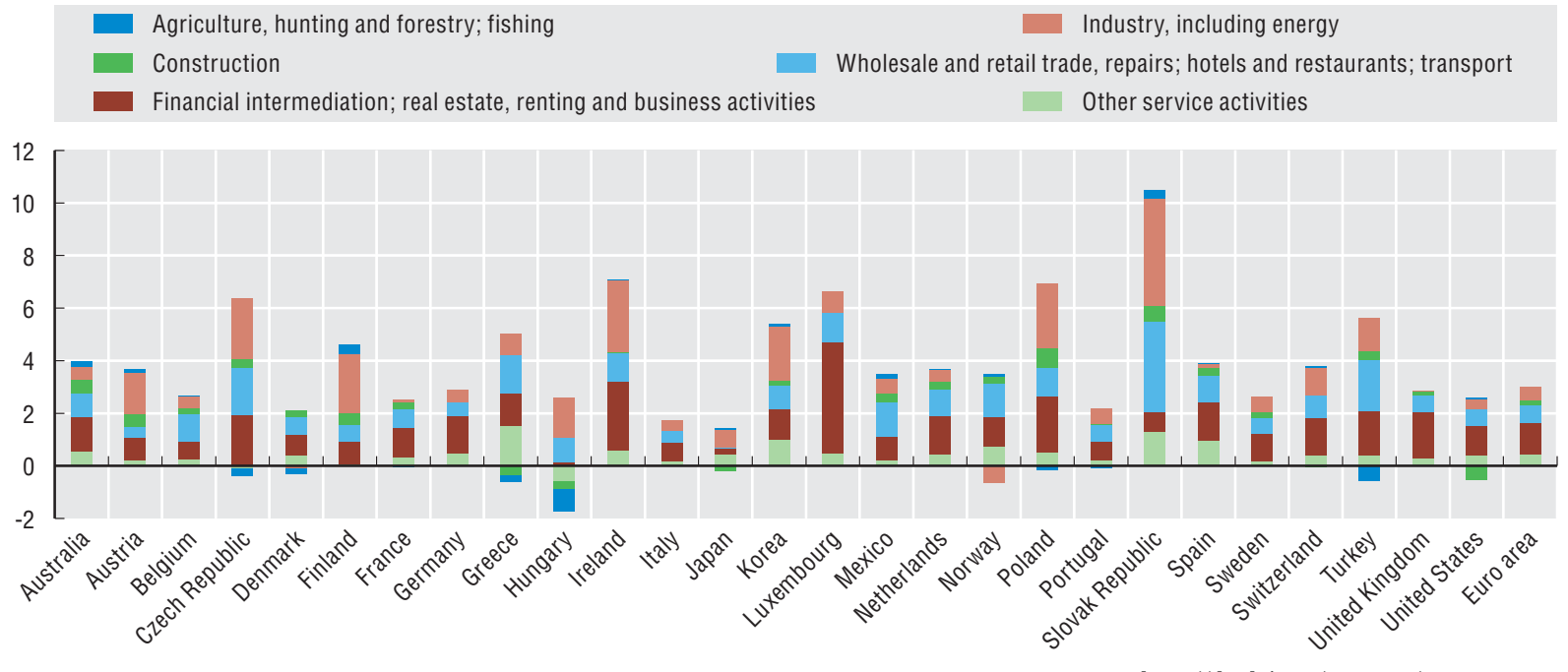

StatLink काsस http://dx.doi.org/10.1787/740150285857 
Compensation of employees reflects the total remuneration in cash or in kind paid to employees and comprises wages and salaries and the value of social contributions paid by employers. They typically form the largest part of value added. Combined with estimates of labour input they provide the basis for a number of important statistics including unit labour costs and average earnings; which play an important role in many countries in monetary policy and cross country comparisons of labour costs.

\section{Definition}

Compensation of employees is made up of two components:

- Wages and salaries payable in cash or in kind: These include the values of any social contributions, income taxes, etc., payable by the employee even if they are actually withheld by the employer and paid on behalf of the employee.

- The value of social contributions payable by employers: these may be the actual social contributions payable by employers to Social Security schemes or to private funded social insurance schemes to secure social benefits for their employees; or imputed social contributions by employers providing social benefits through unfunded schemes.

Compensation of employees is not payable in respect of unpaid work undertaken voluntarily, including the work done by members of a household within an unincorporated enterprise owned by the same household. Compensation of employees excludes any taxes payable by the employer on the wage and salary bill (e.g. payroll tax, fringe benefits tax).

It's important to note that compensation of employees does not represent the entire costs of labour within production. Mixed income, which reflects the income paid to the owner(s) or members of the same household who contribute unpaid labour inputs in unincorporated enterprises owned by households, also contains a labour component.

\section{Comparability}

All countries follow the 1993 SNA and so comparability is generally very good across all countries. Some care should be taken in interpreting labour costs by activity however, especially in a cross-country context. In some countries, and notably in some sectors, the shares of self-employed in the labour force may be significant and, so, differences in the shares of compensation of employees across countries may reflect institutional differences, for example tax incentives to be self-employed or otherwise. This can also have implications in a temporal context. For example systematic declines in the contribution of compensation of employees to value added may reflect a move by individuals to become self-employed rather than a decline in the share of labour overall; this can be both through push and pull mechanisms. For example squeezes on wages and salaries and social benefits (push) or tax incentives (pull).

\section{Source}

- OECD (2009), National Accounts of OECD Countries 2009, Volume I, Main Aggregates, OECD Publishing, http://dx.doi.org/10.1787/na_vol_1-2009-en-fr.

\section{Online database}

- OECD (2009), "Aggregate national accounts: gross domestic product", OECD National Accounts Statistics (database), http://dx.doi.org/10.1787/data-00001-en.

\section{Further reading}

- Lequiller, F. and D. Blades (2007), Understanding National Accounts, OECD Publishing, http://dx.doi.org/10.1787/9789264027657-en.

- OECD (2000), System of National Accounts, 1993 Glossary, OECD Publishing, http://dx.doi.org/10.1787/9789264180871-en.

- UN, OECD, IMF, Eurostat (eds.) (1993), System of National Accounts 1993, United Nations, Geneva, http://unstats.un.org/unsd/sna1993. 
PRODUCTION

15. Compensation of employees

Table 15.1. Compensation of employees

Percentage of gross value added

\begin{tabular}{|c|c|c|c|c|c|c|c|c|c|c|c|c|c|c|}
\hline & 1995 & 1996 & 1997 & 1998 & 1999 & 2000 & 2001 & 2002 & 2003 & 2004 & 2005 & 2006 & 2007 & 2008 \\
\hline Australia & 53.9 & 54.6 & 53.7 & 54.2 & 53.8 & 54.0 & 53.0 & 52.8 & 52.2 & 52.5 & 52.3 & 52.0 & 51.8 & .. \\
\hline Austria & 59.6 & 58.8 & 58.4 & 58.2 & 58.2 & 57.3 & 56.7 & 56.0 & 56.0 & 54.9 & 54.5 & 54.0 & 53.7 & 54.2 \\
\hline Belgium & 56.7 & 57.0 & 56.8 & 56.6 & 57.7 & 57.1 & 58.3 & 58.6 & 58.1 & 56.9 & 56.4 & 56.1 & 56.4 & 57.5 \\
\hline Canada & 55.8 & 55.3 & 55.5 & 56.2 & 55.3 & 54.5 & 55.2 & 55.5 & 55.0 & 54.7 & .. & .. & .. & .. \\
\hline Czech Republic & 47.5 & 48.6 & 48.5 & 46.4 & 46.2 & 46.3 & 46.6 & 47.5 & 48.2 & 47.5 & 48.0 & 47.7 & 47.7 & 49.2 \\
\hline Denmark & 60.3 & 61.0 & 60.9 & 62.9 & 63.2 & 61.2 & 62.5 & 63.2 & 63.5 & 62.7 & 62.9 & 63.3 & 64.6 & 66.0 \\
\hline Finland & 56.8 & 57.3 & 56.1 & 55.3 & 55.3 & 54.2 & 54.3 & 54.5 & 55.7 & 55.3 & 56.6 & 55.6 & 54.4 & 56.5 \\
\hline France & 58.0 & 58.2 & 57.8 & 57.4 & 58.1 & 57.9 & 58.1 & 58.4 & 58.4 & 58.2 & 58.0 & 58.0 & 57.5 & 57.5 \\
\hline Germany & 59.7 & 59.3 & 58.3 & 58.1 & 58.6 & 59.4 & 58.9 & 58.4 & 58.1 & 56.9 & 55.9 & 54.8 & 54.2 & 54.7 \\
\hline Greece & $35.3 \mathrm{e}$ & $35.1 \mathrm{e}$ & $36.3 \mathrm{e}$ & $36.7 \mathrm{e}$ & $38.0 \mathrm{e}$ & 37.6 & 37.1 & 39.8 & 38.9 & 38.7 & 38.7 & 38.7 & 39.1 & 39.3 \\
\hline Hungary & 54.4 & 52.3 & 51.1 & 50.8 & 49.9 & 51.6 & 51.8 & 52.3 & 53.9 & 53.6 & 54.5 & 53.4 & 53.8 & 54.6 \\
\hline Iceland & $56.7 \mathrm{e}$ & $58.6 \mathrm{e}$ & 58.9 & 61.0 & 64.5 & 65.6 & 62.8 & 64.0 & 65.8 & 66.2 & 68.2 & .. & .. & .. \\
\hline Ireland & 50.4 & 49.6 & 48.0 & 46.2 & 45.6 & 44.6 & 44.3 & 43.0 & 43.5 & 44.5 & 46.0 & 46.3 & 46.4 & .. \\
\hline Italy & 45.8 & 45.8 & 46.3 & 44.4 & 44.6 & 43.9 & 43.9 & 44.3 & 44.6 & 44.4 & 45.3 & 46.0 & 45.7 & 46.4 \\
\hline Japan & $52.5 \mathrm{e}$ & 52.1 & 52.1 & 52.4 & 51.9 & 51.8 & 52.1 & 51.2 & 50.5 & 49.6 & 49.5 & 50.2 & 50.1 & .. \\
\hline Korea & $51.8 \mathrm{e}$ & $53.1 \mathrm{e}$ & $51.5 \mathrm{e}$ & $49.3 \mathrm{e}$ & $48.0 \mathrm{e}$ & 48.1 & 49.1 & 49.0 & 50.0 & 49.8 & 51.1 & 51.5 & 51.3 & 51.2 \\
\hline Luxembourg & 52.0 & 51.8 & 53.3 & 53.2 & 51.1 & 51.8 & 54.9 & 55.1 & 52.6 & 52.8 & 51.5 & 48.6 & 48.1 & 48.9 \\
\hline Mexico & $30.4 \mathrm{e}$ & $29.2 \mathrm{e}$ & $30.4 \mathrm{e}$ & $31.2 \mathrm{e}$ & $31.7 \mathrm{e}$ & $32.1 \mathrm{e}$ & $33.2 \mathrm{e}$ & $33.0 \mathrm{e}$ & 32.6 & 30.8 & 30.4 & 29.2 & 29.0 & .. \\
\hline Netherlands & 56.5 & 56.4 & 55.9 & 56.8 & 57.3 & 56.7 & 57.2 & 57.6 & 57.8 & 57.5 & 55.8 & 55.3 & 55.6 & 55.8 \\
\hline New Zealand & 44.1 & 44.9 & 45.1 & 45.0 & 43.5 & 43.3 & 43.2 & 43.8 & 44.2 & 44.6 & .. & .. & .. & .. \\
\hline Norway & 54.2 & 53.1 & 53.1 & 57.6 & 56.3 & 49.0 & 50.1 & 52.7 & 51.7 & 49.5 & 46.8 & 46.1 & 48.6 & 46.7 \\
\hline Poland & 45.1 & 46.5 & 47.2 & 47.2 & 47.1 & 45.2 & 46.0 & 44.3 & 43.3 & 40.7 & 40.6 & 40.4 & 40.6 & 42.4 \\
\hline Portugal & 55.0 & 55.7 & 56.1 & 56.5 & 56.8 & 57.3 & 57.1 & 57.5 & 57.6 & 57.3 & 58.7 & 58.4 & .. & .. \\
\hline Slovak Republic & 44.6 & 46.0 & 47.5 & 47.4 & 45.4 & 45.7 & 44.0 & 43.8 & 43.3 & 41.2 & 41.9 & 40.7 & 40.5 & 40.8 \\
\hline Spain & 53.0 & 53.3 & 54.2 & 54.3 & 54.7 & 54.7 & 54.1 & 53.7 & 53.6 & 53.0 & 52.9 & 53.0 & 53.1 & 52.9 \\
\hline Sweden & 60.3 & 62.4 & 61.9 & 61.9 & 60.7 & 62.9 & 65.1 & 64.6 & 64.0 & 63.1 & 62.8 & 61.4 & 62.4 & 62.2 \\
\hline Switzerland & 64.6 & 64.4 & 64.1 & 63.6 & 64.2 & 64.2 & 66.6 & 67.6 & 67.1 & 65.2 & 65.8 & 64.9 & 64.2 & .. \\
\hline Turkey & .. & .. & .. & .. & .. & .. & .. & .. & .. & .. & .. & .. & .. & .. \\
\hline United Kingdom & 59.0 & 57.8 & 58.1 & 59.6 & 60.3 & 61.6 & 62.2 & 61.4 & 60.8 & 60.6 & 61.2 & 60.8 & 59.8 & 59.5 \\
\hline United States & 61.9 & 61.3 & 61.0 & 62.2 & 62.4 & 63.7 & 63.6 & 63.1 & 63.0 & 62.0 & 61.5 & 61.4 & 61.5 & .. \\
\hline Euro area & 55.6 & 55.3 & 54.8 & 54.4 & 54.8 & 54.7 & 54.6 & 54.5 & 54.3 & 53.7 & 53.5 & 53.2 & 52.9 & 53.2 \\
\hline OECD-Total & .. & .. & .. & .. & .. & .. & .. & .. & .. & .. & .. & .. & .. & .. \\
\hline
\end{tabular}

\section{Figure 15.1. Compensation of employees by activity}

Percentage of gross value added, 2007

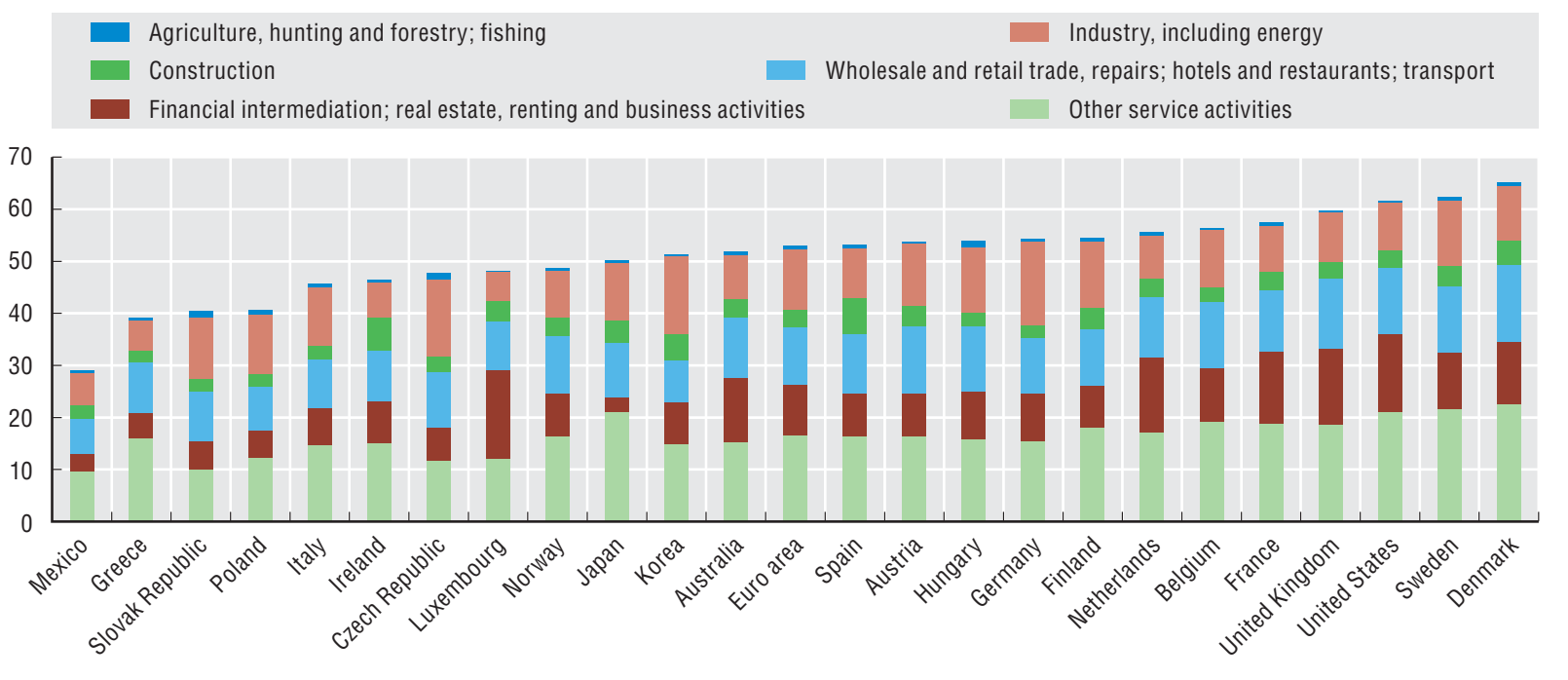

StatLink Aाs Attp://dx.doi.org/10.1787/740213656342 
Section 11 described the concept of general government final consumption, reflecting the contribution government makes as a consumer of final goods and services for individual and collective consumption. Whilst useful in illustrating the scope for government to stimulate demand directly, it does not tell the full story. For a start the measure does not include GFCF of government which is an area where the scope to stimulate demand is considerable. But it also excludes other components of spending by government not recorded as final consumption, for example, debt interest payments, and cash transfers, such as social benefits, which, collectively, better reflect the size of government and its ability to stimulate demand, without changing taxes say, both directly and indirectly. The concept that best reflects this overall expenditure is referred to as general government expenditure. It reflects the total amount of expenditure by government that needs to be financed via revenues, such as taxation, and borrowing.

\section{Definition}

Total general government expenditure (GGE) is equivalent to expenditures by general government on the following items: intermediate consumption, compensation of employees, subsidies, social benefits and social transfers in kind (via market producers), other current transfers, property income, capital transfers (payable), the adjustment for the net equity of households in pension funds reserves, gross capital formation and net acquisition of non-financial non-produced assets. It also includes taxes on income and wealth any other taxes on production that government may be required to pay.

Many of the transactions are better recorded on a consolidated basis (i.e. transactions between general government sub-sectors are netted out) to avoid exaggerating the role of general government. Items that are usually consolidated include: debt interest (part of property income), and capital transfers (except capital taxes payable) and other current transfers.

The government sector covers all units producing (all or mostly) non-market goods and services that are publicly owned. Publicly owned units producing (all or mostly) market goods and services are not in the government sector but are instead recorded as public corporations.

\section{Comparability}

The biggest issue affecting comparability across countries concerns the scope of the government sector. In many countries, hospitals, for example, are classified outside of the government sector and are instead recorded as public corporations; on the grounds that they charge market prices for their services. How significant this is for international comparisons of GGE ultimately depends on the share of goods and services provided to the market, as general government expenditure will still record payments to the hospitals for these services. This is an important point as the guidance provided in the SNA on the delineation of units between market and non-market providers (which refers to most output being non-market) provides scope for differences in country practices. EU countries have adopted a 50\% rule for "most" in this context.

Another potential area where comparability may be affected relates to the determination of public ownership. The SNA requires that "control" be the determining factor and describes a number of criteria that can be used to assess this requirement. Recognising that this is non-trivial it includes a practical recommendation that a $50 \%$ rule relating to share ownership should be adopted. However, in practice, countries may still choose to measure ownership on the basis of the determining criteria.

For most general government expenditures there is little scope for ambiguity in treatment and the quality of underlying data is very good, so the level of comparability is generally good.

Data for all countries are on a consolidated basis, except Canada (which consolidates only current transfers) and New Zealand. Consolidation usually occurs between government sub-sectors (central, local, state and social security funds) but for Austria it is also done within sub-sectors and in Sweden intermediate consumption is also consolidated.

\section{Source}

- OECD (2009), National Accounts of OECD Countries 2009, Volume II, Detailed Tables, OECD Publishing, http://dx.doi.org/10.1787/na_vol_2-2009-en-fr.

\section{Online database}

- OECD (2009), "General government accounts: main aggregates", OECD National Accounts Statistics (database), http://dx.doi.org/10.1787/data-00020-en.

\section{Further reading}

- OECD (2000), System of National Accounts, 1993 Glossary, OECD Publishing, http://dx.doi.org/10.1787/9789264180871-en.

- UN, OECD, IMF, Eurostat (eds.) (1993), System of National Accounts 1993, United Nations, Geneva, http://unstats.un.org/unsd/sna1993. 
Table 16.1. Total general government expenditure

Percentage of GDP

\begin{tabular}{|c|c|c|c|c|c|c|c|c|c|c|c|c|c|c|}
\hline & 1995 & 1996 & 1997 & 1998 & 1999 & 2000 & 2001 & 2002 & 2003 & 2004 & 2005 & 2006 & 2007 & 2008 \\
\hline Australia & 37.4 & 36.7 & 35.5 & 35.3 & 34.8 & 36.0 & 35.6 & 34.9 & 34.8 & 35.1 & 34.6 & 34.4 & 34.1 & .. \\
\hline Austria & 56.3 & 56.0 & 53.7 & 54.0 & 53.7 & 52.1 & 51.6 & 51.0 & 51.5 & 54.0 & 50.1 & 49.6 & 48.8 & 48.9 \\
\hline Belgium & 52.1 & 52.5 & 51.2 & 50.4 & 50.2 & 49.2 & 49.3 & 50.0 & 51.3 & 49.6 & 52.3 & 48.6 & 48.4 & 50.1 \\
\hline Canada & 48.5 & 46.6 & 44.3 & 44.8 & 42.7 & 41.1 & 42.0 & 41.2 & 41.2 & 39.9 & 39.3 & 39.4 & 39.1 & .. \\
\hline Czech Republic & 54.5 & 42.6 & 43.2 & 43.2 & 42.3 & 41.8 & 44.4 & 46.3 & 47.3 & 45.1 & 45.0 & 43.8 & 42.6 & 42.9 \\
\hline Denmark & 59.2 & 58.8 & 56.6 & 56.2 & 55.4 & 53.6 & 54.2 & 54.6 & 55.1 & 54.6 & 52.8 & 51.6 & 51.0 & 51.9 \\
\hline Finland & 61.5 & 59.9 & 56.2 & 52.6 & 51.5 & 48.3 & 47.8 & 48.8 & 50.1 & 50.1 & 50.3 & 48.7 & 47.3 & 49.0 \\
\hline France & 54.4 & 54.5 & 54.1 & 52.7 & 52.6 & 51.6 & 51.6 & 52.6 & 53.3 & 53.2 & 53.4 & 52.7 & 52.3 & 52.7 \\
\hline Germany & 54.8 & 49.3 & 48.4 & 48.0 & 48.1 & 45.1 & 47.6 & 48.1 & 48.5 & 47.1 & 46.8 & 45.4 & 43.7 & 43.7 \\
\hline Greece & 45.7 & 44.1 & 44.9 & 44.3 & 44.4 & 46.7 & 45.3 & 45.1 & 44.7 & 45.4 & 43.8 & 42.8 & 44.4 & 46.3 \\
\hline Hungary & 55.6 & 50.6 & 49.2 & 50.4 & 48.4 & 46.9 & 47.3 & 51.2 & 49.4 & 48.7 & 50.1 & 52.0 & 49.8 & 49.2 \\
\hline Iceland & 42.7 & 42.2 & 40.7 & 41.3 & 42.0 & 41.9 & 42.6 & 44.2 & 45.6 & 44.0 & 42.2 & 41.6 & 42.5 & 58.3 \\
\hline Ireland & 41.1 & 39.1 & 36.7 & 34.5 & 34.1 & 31.3 & 33.2 & 33.5 & 33.2 & 33.5 & 33.7 & 34.2 & 36.2 & 42.0 \\
\hline Italy & 52.5 & 52.4 & 50.2 & 49.2 & 48.2 & 46.2 & 48.0 & 47.4 & 48.3 & 47.7 & 48.2 & 48.7 & 47.9 & 48.7 \\
\hline Japan & .. & 36.8 & 35.7 & 42.5 & 38.6 & 39.0 & 38.6 & 38.8 & 38.4 & 37.0 & 38.4 & 36.2 & 36.0 & .. \\
\hline Korea & .. & .. & .. & .. & .. & 22.4 & 23.9 & 23.6 & 28.9 & 26.1 & 26.6 & 27.7 & 28.6 & .. \\
\hline Luxembourg & 39.7 & 41.1 & 40.6 & 41.1 & 39.2 & 37.6 & 38.1 & 41.5 & 41.8 & 42.6 & 41.5 & 38.3 & 36.2 & 37.7 \\
\hline Mexico & .. & .. & .. & .. & .. & .. & .. & .. & .. & .. & .. & .. & .. & .. \\
\hline Netherlands & 56.4 & 49.4 & 47.5 & 46.7 & 46.0 & 44.2 & 45.4 & 46.2 & 47.1 & 46.1 & 44.8 & 45.5 & 45.5 & 45.9 \\
\hline New Zealand & 41.6 & 40.9 & 41.4 & 41.1 & 40.4 & 38.7 & 37.9 & 37.2 & 37.7 & 37.6 & 38.5 & 39.5 & 39.7 & .. \\
\hline Norway & 50.9 & 48.5 & 46.8 & 49.1 & 47.7 & 42.3 & 44.1 & 47.1 & 48.2 & 45.4 & 42.1 & 40.5 & 40.9 & 40.0 \\
\hline Poland & 47.7 & 51.0 & 46.4 & 44.3 & 42.7 & 41.1 & 43.8 & 44.2 & 44.6 & 42.6 & 43.4 & 43.9 & 42.2 & 43.3 \\
\hline Portugal & 43.4 & 44.1 & 43.2 & 42.8 & 43.2 & 43.1 & 44.4 & 44.3 & 45.5 & 46.5 & 47.6 & 46.3 & 45.8 & 46.0 \\
\hline Slovak Republic & 48.6 & 53.7 & 49.0 & 45.8 & 48.1 & 52.2 & 44.5 & 45.0 & 40.1 & 37.6 & 38.0 & 36.9 & 34.4 & 34.7 \\
\hline Spain & 44.4 & 43.2 & 41.6 & 41.1 & 39.9 & 39.1 & 38.6 & 38.9 & 38.4 & 38.9 & 38.4 & 38.4 & 39.2 & 41.1 \\
\hline Sweden & 65.1 & 63.0 & 60.9 & 58.8 & 58.6 & 55.6 & 55.5 & 56.7 & 57.0 & 55.6 & 55.2 & 54.1 & 52.6 & 53.1 \\
\hline Switzerland & 35.0 & 35.3 & 35.5 & 35.8 & 34.3 & 35.1 & 34.8 & 36.2 & 36.4 & 36.0 & 35.3 & 33.5 & 32.2 & .. \\
\hline Turkey & .. & .. & .. & .. & .. & .. & .. & .. & .. & .. & .. & .. & .. & .. \\
\hline United Kingdom & 43.9 & 42.3 & 40.5 & 39.5 & 38.9 & 39.0 & 40.1 & 41.0 & 42.0 & 43.0 & 44.1 & 44.2 & 44.0 & 47.5 \\
\hline United States & 37.1 & 36.6 & 35.5 & 34.6 & 34.2 & 33.9 & 35.0 & 35.9 & 36.3 & 36.0 & 36.3 & 36.0 & 36.7 & 38.8 \\
\hline Euro area & .. & .. & .. & 48.5 & 48.1 & 46.3 & 47.3 & 47.6 & 48.1 & 47.5 & 47.4 & 46.6 & 46.0 & 46.7 \\
\hline OECD-Total & .. & .. & .. & .. & .. & .. & .. & .. & .. & .. & .. & .. & .. & .. \\
\hline
\end{tabular}

Figure 16.1. Total general government expenditure by main component Percentage of GDP, 2007

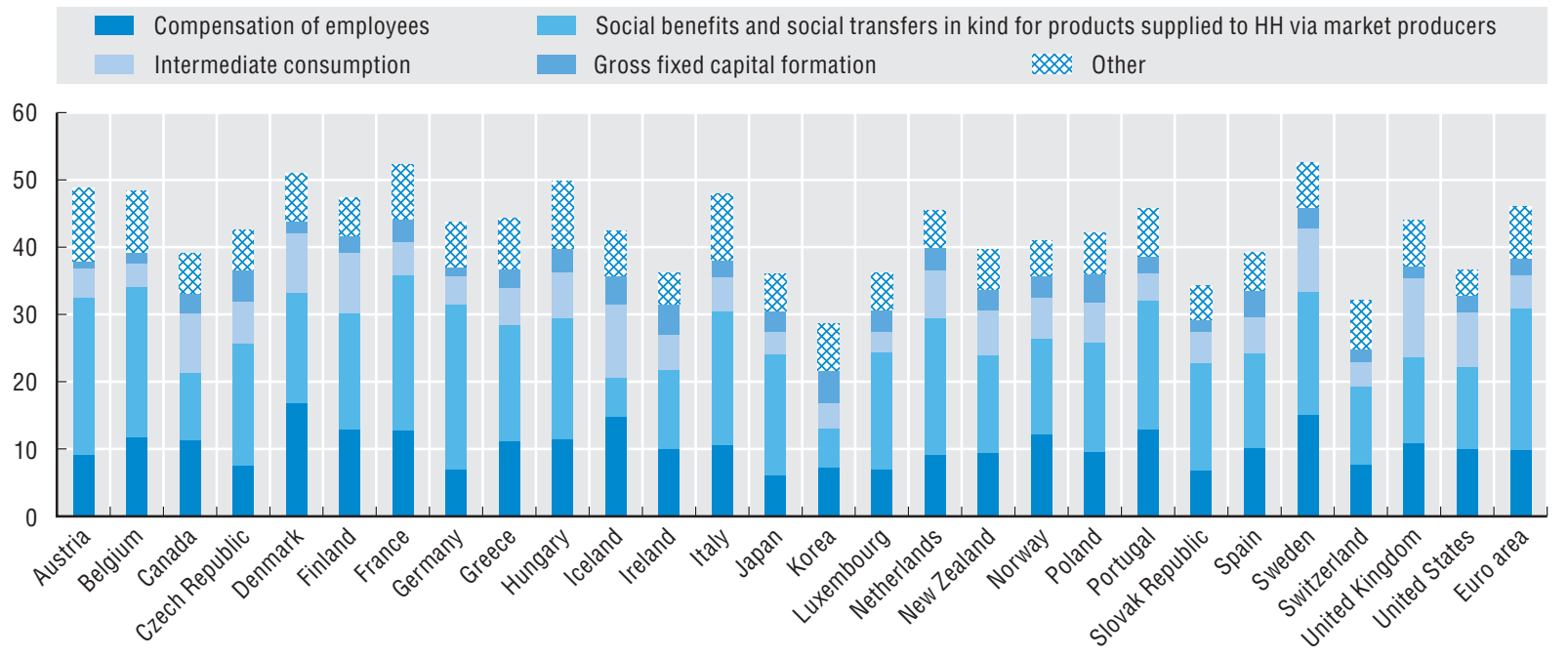

StatLink काIs http://dx.doi.org/10.1787/740255035375 
In the SNA, taxes are compulsory unrequited payments, in cash or in kind, made by institutional units to the general government exercising its sovereign powers or to a supranational authority and generally constitute the major part of government revenue in most countries. Social security contributions, which although being compulsory payments to general government, are not treated as taxes in the SNA because the receipt of social security benefits depends, in most countries, upon appropriate contributions having been made, even though the size of the benefits is not necessarily related to the amount of the contributions. However, many policy makers and users prefer to define taxes to include social security contributions. Indeed this is the basis of tax measures used in the OECD Revenue Statistics publication. This partly reflects the fact that the contributions to general government are compulsory but also because not all countries operate social security schemes, choosing instead to finance social benefits paid by government through other taxes or revenue (see also Section 18).

From a practical policy perspective, definitions of taxes that include social security contributions are generally preferred. This section however focuses on the SNA definition.

\section{Definition}

The SNA describes three categories of taxes:

- The first category, taxes on production and imports, historically referred to as indirect taxes, is broken down into two components in the SNA: taxes on products, such as VAT, and other taxes on production such as taxes on the ownership or use of land, buildings or other assets used in production or on labour employed (payroll tax).

- The second category, current taxes on income, wealth, etc., consists mainly of taxes levied on the incomes of households and corporations. The category is not described simply as "current taxes on income and wealth" because it includes periodic taxes on households that are assessed neither on the income nor the wealth of the household or its members, for example, poll taxes.

- The final category, capital taxes, consists of taxes levied at irregular and very infrequent intervals on the values of assets or net worth owned by or transferred between units, such as inheritance taxes and betterment levies, e.g. taxes on the increase in the value of land resulting from planning permission.

\section{Definition of taxes used in OECD Revenue Statistics}

The Revenue Statistics definition differs from the SNA in the following respects:

- Includes social contributions paid to government.

- Adopts different views on whether some fees and licenses at the margin are taxes.

- Excludes imputed taxes/subsidies related to the operation of official multiple exchange rates.

- Nets off some tax credits within overall taxes that the SNA records as government expenditure.

\section{Comparability}

Generally the comparability of taxes across countries is good but the rules that delineate taxes from revenues, (typically those relating to fees/licenses) may at the margin, cause some comparability issues. In general, if the issue of a licence involves little work by government the related fee should be recorded as a tax. But if government provides some service associated with, and in proportion to the size of, the fee, it is treated as a purchase of services.

Fees for licenses to use natural resources (radio spectra, land, fish) are nearly always recorded as rent or payments for an asset and not as taxes. But not all, e.g. licenses for recreational, as opposed to commercial, fishing. Indeed, payments by persons or households for licences to own or use vehicles, boats or aircraft and for licences for recreational hunting, shooting or fishing are treated as taxes. Fees for licenses to engage in a specific activity (e.g. to operate a taxi or casino) are generally treated as a tax. Payments for all other kinds of licences (e.g. driving, television, firearm) or fees to government (e.g. payments for passports) are generally but not universally treated as purchases of services.

The chart below shows general government revenue (taxes plus other government receipts/revenues) $=$ general government expenditure $+/(-)$ net lending (borrowing), as a percentage of GDP.

\section{Source}

- OECD (2009), National Accounts of OECD Countries 2009, Volume II, Detailed Tables, OECD Publishing, http://dx.doi.org/10.1787/na_vol_2-2009-en-fr.

\section{Online database}

- OECD (2009), "General government accounts: main aggregates", OECD National Accounts Statistics (database), http://dx.doi.org/10.1787/data-00020-en.

\section{Further reading}

- OECD (2009), Revenue Statistics, OECD Publishing, http://dx.doi.org/10.1787/rev_stats-2009-en-fr.

- IMF (2001), Government Finance Statistics Manual, IMF, Washington. 
Table 17.1. Taxes in the System of National Accounts (SNA)

Percentage of GDP

\begin{tabular}{|c|c|c|c|c|c|c|c|c|c|c|c|c|}
\hline & \multicolumn{3}{|c|}{ Total tax receipts } & \multicolumn{3}{|c|}{ Taxes on production and imports } & \multicolumn{3}{|c|}{ Current taxes on income, wealth, etc. } & \multicolumn{3}{|c|}{ Capital taxes } \\
\hline & 1997 & 2002 & 2007 & 1997 & 2002 & 2007 & 1997 & 2002 & 2007 & 1997 & 2002 & 2007 \\
\hline Australia & 29.8 & 30.8 & 30.6 & 12.1 & 13.2 & 12.2 & 17.7 & 17.6 & 18.4 & 0.0 & 0.0 & 0.0 \\
\hline Austria & 28.5 & 28.9 & 27.6 & 14.9 & 15.0 & 14.1 & 13.5 & 13.9 & 13.5 & 0.0 & 0.1 & 0.1 \\
\hline Belgium & 29.8 & 30.2 & 29.7 & 12.7 & 12.7 & 12.7 & 16.8 & 17.1 & 16.3 & 0.4 & 0.5 & 0.7 \\
\hline Canada & .. & .. & .. & 14.0 & 13.1 & 11.9 & 17.7 & 15.5 & 16.7 & .. & .. & .. \\
\hline Czech Republic & 20.4 & 19.9 & 20.6 & 11.5 & 10.8 & 11.2 & 8.8 & 9.1 & 9.4 & 0.0 & 0.0 & 0.0 \\
\hline Denmark & 47.9 & 46.6 & 47.6 & 17.4 & 17.4 & 17.8 & 30.3 & 29.1 & 29.6 & 0.2 & 0.2 & 0.2 \\
\hline Finland & 32.9 & 32.5 & 30.8 & 14.3 & 13.4 & 13.0 & 18.4 & 18.8 & 17.6 & 0.2 & 0.3 & 0.3 \\
\hline France & 25.6 & 26.7 & 27.0 & 15.9 & 14.9 & 15.1 & 9.2 & 11.3 & 11.4 & 0.5 & 0.5 & 0.5 \\
\hline Germany & 22.3 & 22.4 & 23.9 & 11.2 & 11.7 & 12.6 & 11.0 & 10.6 & 11.2 & 0.1 & 0.1 & 0.2 \\
\hline Greece & 20.0 & 21.7 & 20.4 & 12.7 & 12.9 & 12.3 & 7.0 & 8.6 & 7.9 & 0.4 & 0.2 & 0.2 \\
\hline Hungary & 23.9 & 25.0 & 25.9 & 15.2 & 14.9 & 15.6 & 8.7 & 10.0 & 10.2 & 0.0 & 0.1 & 0.1 \\
\hline Iceland & 31.9 & 32.4 & 37.7 & 17.8 & 15.9 & 18.7 & 14.1 & 16.5 & 19.0 & 0.0 & 0.0 & 0.0 \\
\hline Ireland & 27.3 & 23.8 & 26.2 & 13.3 & 12.2 & 13.4 & 13.8 & 11.5 & 12.6 & 0.2 & 0.1 & 0.2 \\
\hline Italy & 28.7 & 28.4 & 29.8 & 12.2 & 14.3 & 14.7 & 15.8 & 13.9 & 15.1 & 0.7 & 0.2 & 0.0 \\
\hline Japan & 18.2 & 16.8 & 18.2 & 7.9 & 8.4 & 8.4 & 9.8 & 8.0 & 9.5 & 0.5 & 0.3 & 0.3 \\
\hline Korea & .. & 19.1 & 21.4 & .. & 12.5 & 12.0 & .. & 6.5 & 9.0 & .. & 0.1 & 0.3 \\
\hline Luxembourg & 28.6 & 28.1 & 25.6 & 12.1 & 12.7 & 12.5 & 16.4 & 15.2 & 13.0 & 0.1 & 0.1 & 0.1 \\
\hline Mexico & .. & .. & .. & .. & .. & .. & .. & .. & .. & .. & .. & .. \\
\hline Netherlands & 23.6 & 23.9 & 24.8 & 11.2 & 12.1 & 12.5 & 12.1 & 11.4 & 12.0 & 0.3 & 0.4 & 0.3 \\
\hline New Zealand & 34.2 & 32.8 & 35.3 & 13.3 & 12.9 & 12.8 & 20.9 & 19.9 & 22.5 & 0.0 & 0.0 & 0.0 \\
\hline Norway & 32.6 & 33.2 & 34.6 & 15.8 & 13.4 & 12.6 & 16.8 & 19.7 & 21.8 & 0.1 & 0.1 & 0.1 \\
\hline Poland & 24.9 & 20.1 & 22.7 & 13.9 & 13.2 & 14.1 & 11.0 & 6.9 & 8.6 & 0.0 & 0.0 & 0.0 \\
\hline Portugal & 22.3 & 23.6 & 24.8 & 13.1 & 14.2 & 15.0 & 9.1 & 9.3 & 9.8 & 0.1 & 0.1 & 0.0 \\
\hline Slovak Republic & 22.3 & 18.4 & 17.2 & 13.1 & 11.4 & 11.0 & 9.2 & 7.0 & 6.2 & 0.0 & 0.0 & 0.0 \\
\hline Spain & 20.9 & 22.0 & 25.1 & 10.3 & 11.2 & 11.7 & 10.3 & 10.4 & 12.9 & 0.4 & 0.4 & 0.5 \\
\hline Sweden & 37.2 & 34.1 & 35.9 & 16.0 & 16.4 & 16.8 & 21.1 & 17.5 & 19.1 & 0.1 & 0.1 & 0.0 \\
\hline Switzerland & 20.3 & 22.2 & 22.1 & 6.3 & 7.1 & 6.9 & 13.8 & 14.8 & 15.0 & 0.3 & 0.3 & 0.2 \\
\hline Turkey & .. & .. & .. & .. & .. & .. & .. & .. & .. & .. & .. & .. \\
\hline United Kingdom & 28.1 & 28.6 & 29.4 & 12.9 & 12.9 & 12.5 & 15.0 & 15.5 & 16.6 & 0.2 & 0.2 & 0.3 \\
\hline United States & 21.8 & 19.2 & 21.4 & 7.4 & 7.2 & 7.3 & 14.1 & 11.7 & 13.8 & 0.3 & 0.3 & 0.2 \\
\hline Euro area & .. & 25.2 & 26.2 & .. & 13.1 & 13.5 & .. & 11.8 & 12.4 & .. & 0.3 & 0.3 \\
\hline OECD-Total & .. & .. & .. & .. & .. & .. & .. & .. & .. & .. & .. & .. \\
\hline
\end{tabular}

StatLink काज् http://dx.doi.org/10.1787/741243416728

Figure 17.1. Total general government revenue

Percentage of GDP, 2007

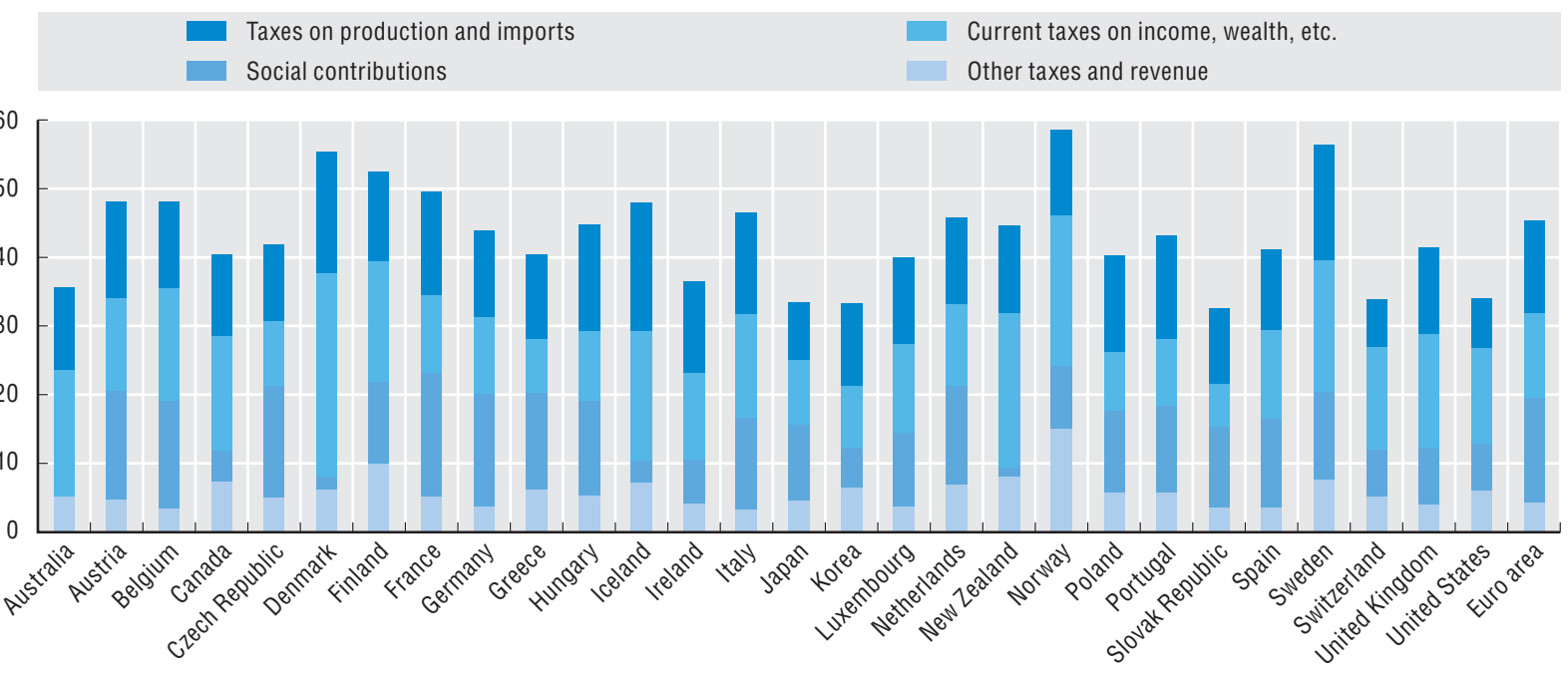

StatLink क्ञाs http://dx.doi.org/10.1787/740278061823 
Social contributions are actual or imputed payments to social insurance schemes to make provision for social insurance benefits (see Section 17). They may be made by employers on behalf of their employees or by employees, self-employed or non-employed persons on their own behalf. The contributions may be compulsory or voluntary and the schemes may be funded or unfunded. Compulsory social security contributions paid to general government or to social security funds under the effective control of government form an important part of government revenue and, although they are not treated so in the SNA, many analysts (including the OECD's Tax Directorate) consider the payments as being analogous to a tax on income and so part of a country's overall tax burden. They are important not only in the sense that they form a significant share of government revenue but because they also reflect part of the costs of doing business. In many developing countries high social contributions coupled with low social benefits are often cited as a reason for a large informal economy.

\section{Definition}

Social insurance schemes may be managed by any sector and the schemes may be funded or unfunded. Moreover the contributions paid to the schemes may be compulsory or voluntary. Typically the most important types of schemes are social security schemes; i.e. those imposed, controlled and financed by government. But in many countries the role of private funded or unfunded schemes is growing.

Social security funds established for social security schemes are separate institutional units in the SNA, forming a subcomponent of the government sector. Although contributions to the scheme are obligatory, payments can be made to the funds on a voluntary basis to qualify for social security benefits. Social insurance schemes organised by government for their own employees are classified as private funded or unfunded schemes as appropriate.

\section{Comparability}

Not all countries operate social security schemes. Some may choose instead to finance social benefits paid by government through other taxes or revenue; which is one of the reasons why analysts often prefer to show the totality of taxes and social contributions in calculating the tax burden. But even these comparisons should be interpreted carefully. Governments may encourage employers and employees to opt-out of social security schemes and instead pay contributions, even if compulsory, to schemes managed by corporations, thus reducing the revenues and expenditures of government, without necessarily reducing the well-being of households. This is one of the reasons why comparisons of taxes on income are often shown as rates, with the component for social contributions reflecting the compulsory rate irrespective of whether the associated scheme is managed by government or corporations.

In Finland, Iceland and the Netherlands, some contributions are levied as a function of taxable income (i.e. gross wage earnings after most/all tax reliefs). Australia and New Zealand do not levy social security contributions.

The figures shown below include both voluntary and compulsory social contributions paid to government.

\section{Source}

- OECD (2009), National Accounts of OECD Countries 2009, Volume II, Detailed Tables, OECD Publishing, http://dx.doi.org/10.1787/na_vol_2-2009-en-fr.

\section{Online database}

- OECD (2009), "General government accounts: main aggregates", OECD National Accounts Statistics (database), http://dx.doi.org/10.1787/data-00020-en.

\section{Further reading}

- Lequiller, F. and D. Blades (2007), Understanding National Accounts, OECD Publishing, http://dx.doi.org/10.1787/9789264027657-en.

- OECD (2000), System of National Accounts, 1993 Glossary, OECD Publishing, http://dx.doi.org/10.1787/9789264180871-en.

- UN, OECD, IMF, Eurostat (eds.) (1993), System of National Accounts 1993, United Nations, Geneva, http://unstats.un.org/unsd/sna1993. 


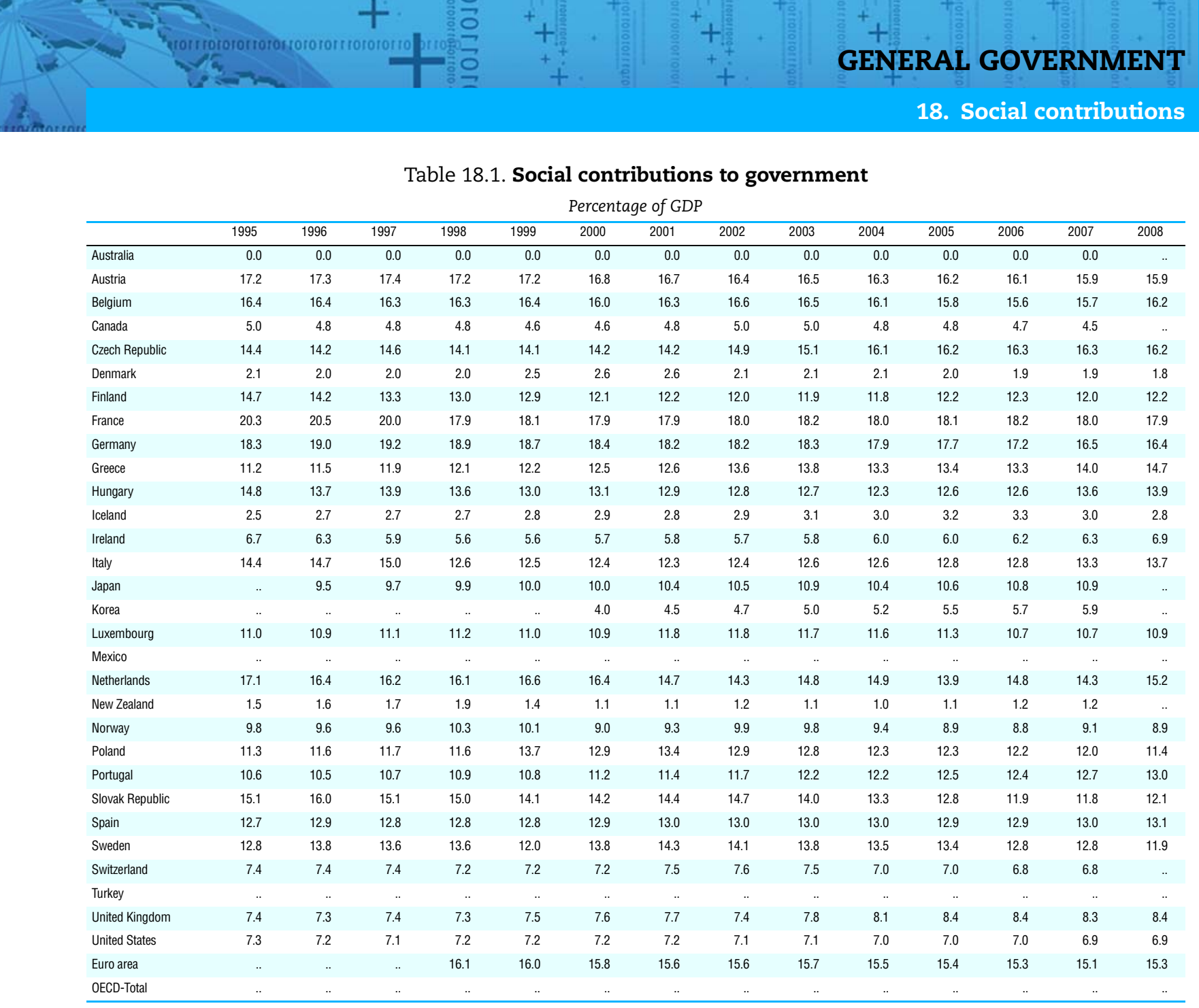

Figure 18.1. Social contributions to government

Percentage of GDP, 2007

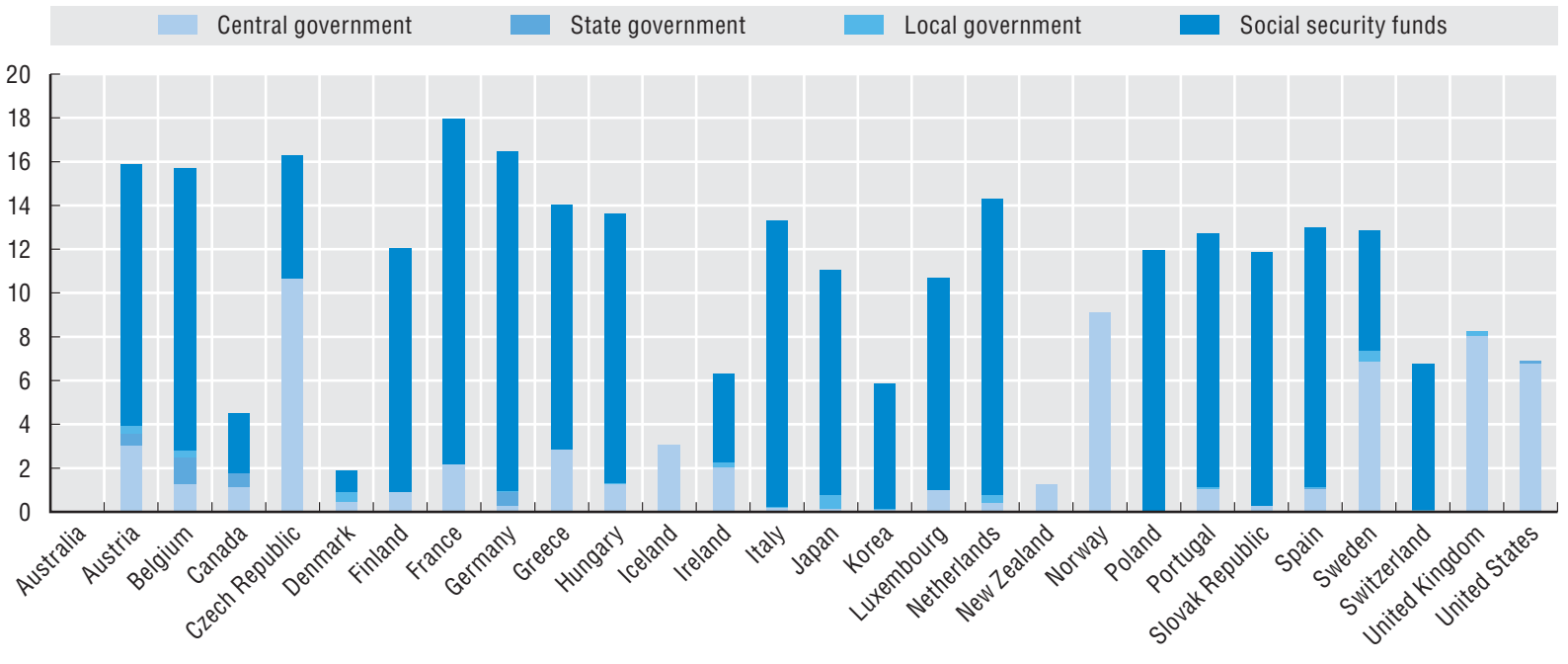

StatLink ताsस http://dx.doi.org/10.1787/740348361858 
Social benefits reflect current transfers to households in cash or in kind to provide for the needs that arise from certain events or circumstances, for example sickness, unemployment, retirement, housing, education or family circumstances that may adversely affect the well-being of the households concerned either by imposing additional demands on their resources or by reducing their incomes. Transfers are typically made by governments and NPISH, and they form a significant share of total general government expenditure and households disposable income; particularly for the lower income groups of society. They are an important factor in analyses of households' welfare and income inequality and the redistributive role of government.

\section{Definition}

The National Accounts has two distinct categories of Social benefits: the first is Social benefits other than social transfers in kind. The second is Social transfers in kind (see also Sections 5, 10 and 11). The distinction between the two is important. Transfers relating to the former are typically in cash and so allow households to use the cash indistinguishably from income coming from other sources, whereas transfers under the latter are always in kind, and so households have no discretion over their use.

Social benefits other than social transfers in kind is further broken down into two key components: Social insurance benefits and social assistance benefits in cash.

The latter consist of cash transfers made by government units or NPISHs to households to meet the same kinds of needs as social insurance benefits but where the households or needs are outside of any social insurance scheme or where the social insurance benefits are not considered sufficient to cover the needs. It does not include payments to government/NPISH employees in their capacity as current or former employees.

The SNA breaks down Social insurance benefits into three further categories: Social Security benefits in cash; Unfunded employee social insurance benefits; and Private funded social insurance benefits. The first two are most relevant for government and the first, in particular, reflects a significant proportion of government expenditure. It includes cash payments for: sickness and invalidity benefits; children, family, dependants' and maternity allowances; unemployment benefits; pensions; and death benefits. Unfunded employee social insurance benefits include cash or in kind payments to employees for similar circumstances including payments on general medical services not related to the employee's work. Government as an employer incurs expenditures here, typically reflecting employee pensions.

Social transfers in kind reflect payments for individual goods and services such as education, health and housing, provided by government and NPISHs, to households either free or at prices that are not economically significant.

\section{Comparability}

Whilst there are significant differences between Social transfers in kind and Social benefits other than social transfers in kind vis-à-vis households' choice, they are not entirely mutually exclusive in a policy context. Governments for example can provide pensions that include a free housing component, (and this component would be recorded as a social transfer in kind) rather than a pension in cash that allows the recipient to pay a market rent. Similarly some governments provide food coupons, which would be recorded as a social transfer in kind, instead of cash benefits.

This suggests that international comparisons of social benefits should focus on the totality, those in kind and in cash. Indeed comparisons of the components of social benefits other than social transfers in kind should also be attempted with some caution as the coverage of people and consequences/needs in social insurance schemes varies across countries. A further caveat concerns social benefits paid to government employees as these can be delivered through private funded rather than unfunded schemes.

Moreover, in practice not all countries record all social transfers in kind in the same way. Some countries treat the reimbursements on some individual goods and services in the secondary distribution of income account; with the reimbursed component forming part of household final consumption and not general government final consumption. Total general government expenditure, households' actual final consumption, disposable income, adjusted disposable income and saving are unaffected by these differences however.

\section{Source}

- OECD (2009), National Accounts of OECD Countries 2009, Volume II, Detailed Tables, OECD Publishing, http://dx.doi.org/10.1787/na_vol_2-2009-en-fr.

\section{Online database}

- OECD (2009), "General government accounts: main aggregates", OECD National Accounts Statistics (database), http://dx.doi.org/10.1787/data-00020-en.

\section{Further reading}

- Lequiller, F. and D. Blades (2007), Understanding National Accounts, OECD Publishing, http://dx.doi.org/10.1787/9789264027657-en.

- OECD (2000), System of National Accounts, 1993 Glossary, OECD Publishing, http://dx.doi.org/10.1787/9789264180871-en.

- UN, OECD, IMF, Eurostat (eds.) (1993), System of National Accounts 1993, United Nations, Geneva, http://unstats.un.org/unsd/sna1993. 


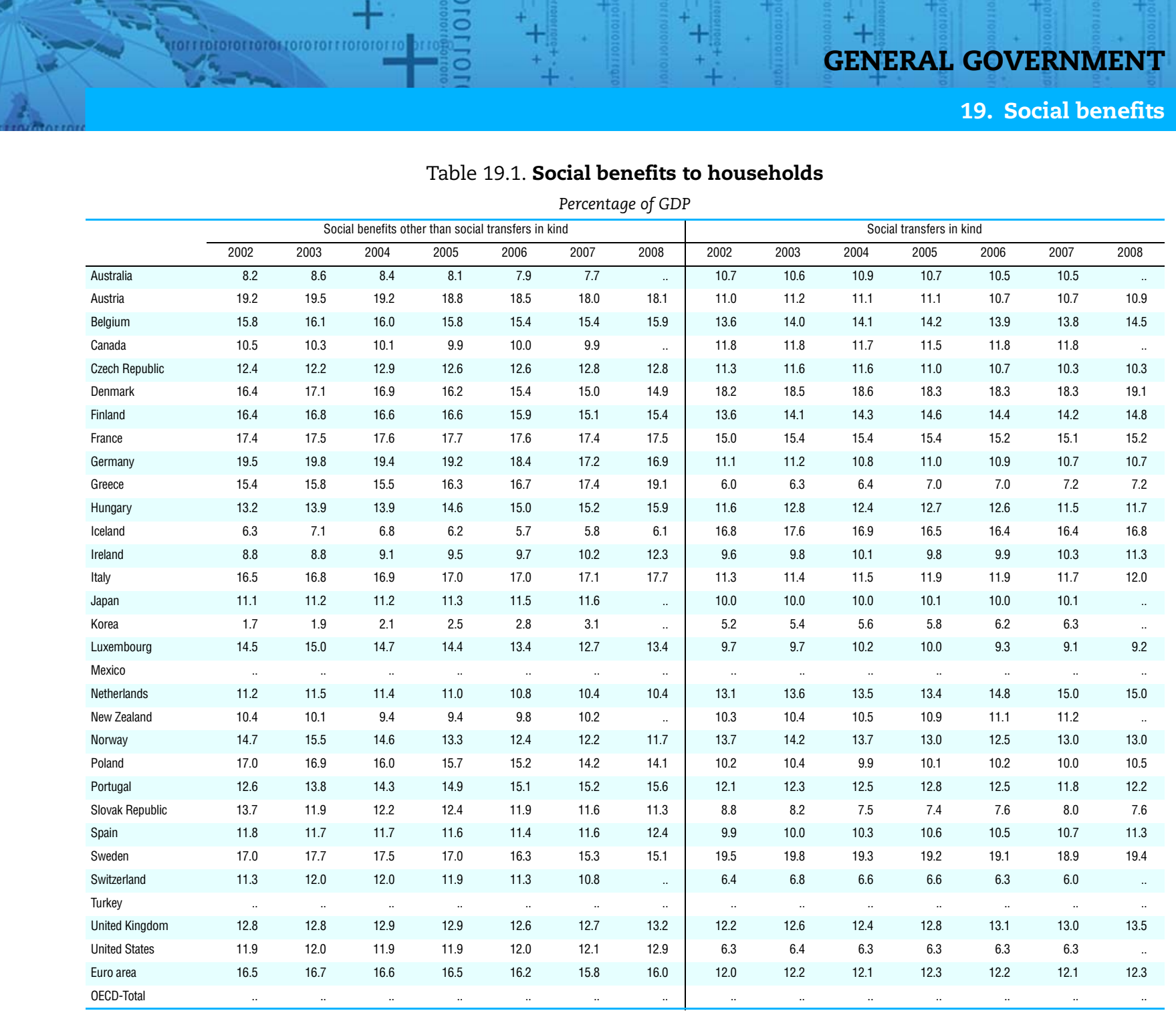

StatLink ताIs/ $h t t p: / / d x . d o i . o r g / 10.1787 / 741278604018$

Figure 19.1. Social benefits to households

Percentage of total general government expenditure, 2007

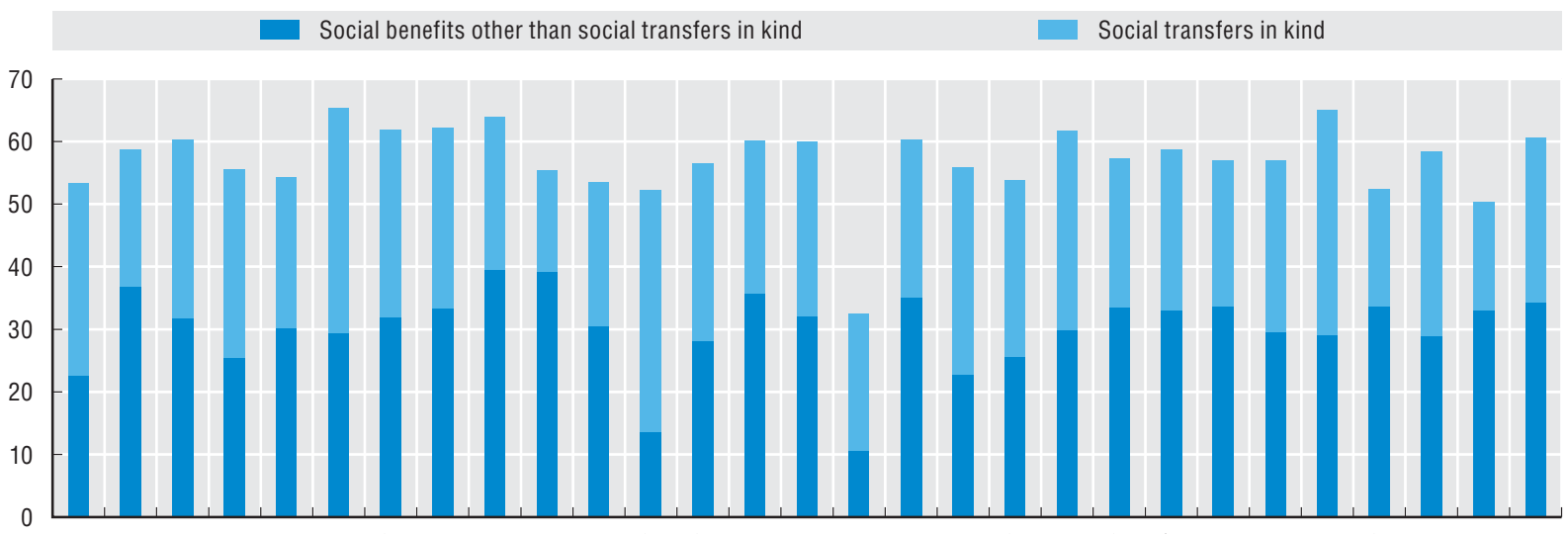

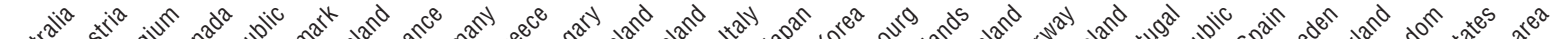

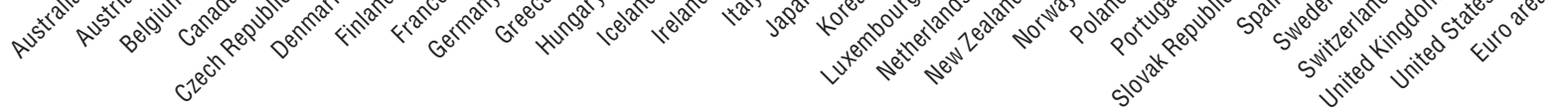


The amount of financial assets and liabilities held by government has significant political and economic importance. The assets reflect a source of additional income available to government and a source of funds that it can draw on without necessarily increasing liabilities, for example as an additional lever to protect its currency when money markets exert prohibitive upward pressure on bond yields say. The liabilities reflect the debts accumulated by government and, so, provide an indication of the structural nature of debt interest payments (which add to government deficit). This matters because, in general, the higher the liabilities the higher the perceived risk of default (and therefore the higher the risk premium required by the market). Typically, this cycle can eventually force governments to either cut spending or raise taxes. General government gross debt's importance, and, in particular, the importance of sustainable levels of debt, is reflected in the European Maastricht criteria, where it is one of the two measures referred to in the Excessive Deficit Procedure.

\section{Definition}

The SNA defines the following as financial assets: Monetary gold and Special Drawing Rights; Currency and deposits; Securities other than shares; Shares and other equity; Loans; Insurance technical reserves; and Other accounts receivable/payable.

The valuations of both assets and liabilities in the balance sheets should be at the market prices at the end of the year and preferably with the accounts consolidating assets and liabilities between all general government sectors.

The measure used by the European Commission as part of the excessive debt procedure (General Government Gross Debt) is also consolidated but is based on nominal valuations, that is, the amount contractually agreed to be repaid by government on maturity. It also excludes any liabilities relating to Shares and other equity, Insurance technical reserves, and Other accounts payable and also Financial derivatives (part of Securities other than shares).

\section{Comparability}

All countries follow the 1993 SNA.

Data are not consolidated for: Canada, Czech Republic, Iceland, Japan, Korea, Switzerland and United Kingdom.

\section{Source}

- OECD (2008), National Accounts of OECD Countries 2008, Volume IIIb, Financial Balance Sheets: Stocks, OECD Publishing, http://dx.doi.org/10.1787/na_vol_3b-2008-en-fr.

\section{Online databases}

- OECD (2009), "Financial balance sheets: consolidated stocks", OECD National Accounts Statistics (database), http://dx.doi.org/10.1787/data-00024-en.

- OECD, "Financial balance sheets: non consolidated stocks", OECD National Accounts Statistics (database), http://dx.doi.org/10.1787/data-00025-en.

\section{Further reading}

- Lequiller, F. and D. Blades (2007), Understanding National Accounts, OECD Publishing, http://dx.doi.org/10.1787/9789264027657-en.

- OECD (2000), System of National Accounts, 1993 Glossary, OECD Publishing, http://dx.doi.org/10.1787/9789264180871-en.

- UN, OECD, IMF, Eurostat (eds.) (1993), System of National Accounts 1993, United Nations, Geneva, http://unstats.un.org/unsd/sna1993. 
Table 20.1. Financial assets and liabilities of general government

Percentage of GDP

\begin{tabular}{|c|c|c|c|c|c|c|c|c|c|c|c|c|c|c|}
\hline & \multicolumn{7}{|c|}{ Financial assets } & \multicolumn{7}{|c|}{ Liabilities } \\
\hline & 2002 & 2003 & 2004 & 2005 & 2006 & 2007 & 2008 & 2002 & 2003 & 2004 & 2005 & 2006 & 2007 & 2008 \\
\hline Australia & 29.8 & 26.5 & 26.3 & 25.5 & 25.4 & 25.7 & .. & 34.4 & 31.8 & 30.2 & 29.3 & 28.6 & 27.4 & .. \\
\hline Austria & 36.0 & 35.2 & 32.8 & 32.8 & 32.8 & 31.2 &.. & 73.1 & 71.3 & 70.7 & 70.5 & 66.2 & 61.9 & .. \\
\hline Belgium & 15.2 & 13.2 & 14.6 & 14.0 & 14.4 & 14.8 & 19.6 & 108.3 & 103.5 & 98.3 & 96.0 & 91.4 & 87.6 & 93.1 \\
\hline Canada & 47.2 & 47.8 & 47.2 & 50.9 & 51.7 & 50.3 & .. & 113.4 & 107.7 & 101.0 & 99.5 & 95.3 & 89.7 & .. \\
\hline Czech Republic & 55.1 & 47.8 & 48.4 & 47.7 & 46.0 & 48.0 &.. & 39.2 & 40.6 & 39.0 & 36.5 & 35.1 & 34.1 & .. \\
\hline Denmark & 34.9 & 36.0 & 38.0 & 33.4 & 35.1 & 34.3 &.. & 55.4 & 53.6 & 50.1 & 42.4 & 37.7 & 31.2 & .. \\
\hline Finland & 80.8 & 90.9 & 97.4 & 106.3 & 112.9 & 112.6 &.. & 49.4 & 51.3 & 51.5 & 48.5 & 45.2 & 41.4 & .. \\
\hline France & 25.6 & 27.4 & 28.8 & 32.7 & 34.1 & 35.6 & .. & 67.5 & 71.6 & 74.0 & 75.9 & 71.6 & 70.0 & .. \\
\hline Germany & 21.3 & 21.8 & 21.1 & 21.2 & 21.2 & 20.9 & .. & 62.2 & 65.4 & 68.4 & 71.0 & 69.3 & 65.4 & .. \\
\hline Greece & 22.6 & 24.8 & 26.5 & 29.2 & 30.2 & 33.6 & 28.8 & 117.2 & 112.0 & 114.2 & 114.5 & 107.9 & 103.9 & 102.8 \\
\hline Hungary & 24.1 & 24.2 & 23.5 & 22.6 & 20.2 & 19.3 &.. & 60.7 & 61.8 & 65.0 & 68.8 & 71.9 & 72.0 & .. \\
\hline Iceland & 45.5 & 42.1 & 38.3 & 40.4 & 51.2 & 56.0 & .. & 74.0 & 72.8 & 65.9 & 54.0 & 59.1 & 55.2 & .. \\
\hline Ireland & 21.2 & 22.5 & 23.7 & 26.2 & 27.6 & 28.7 & 37.1 & 35.2 & 34.1 & 32.7 & 32.7 & 28.8 & 28.3 & 48.5 \\
\hline Italy & 23.6 & 24.1 & 24.8 & 26.3 & 26.5 & 25.4 &.. & 119.4 & 116.9 & 117.2 & 119.8 & 116.8 & 112.5 & .. \\
\hline Japan & 91.1 & 96.7 & 99.9 & 109.0 & 108.0 & .. & .. & 165.0 & 174.9 & 182.5 & 191.0 & 191.2 &.. & .. \\
\hline Korea & 51.3 & 50.2 & 53.9 & 60.1 & 64.5 & 67.2 &.. & 19.0 & 19.2 & 22.5 & 24.5 & 27.6 & 27.2 & .. \\
\hline Luxembourg & .. & .. & .. & .. & .. & .. &.. & .. & .. &.. & .. & .. & .. & .. \\
\hline Mexico & 2.0 & 2.8 & 2.8 & 2.9 & 2.6 & 3.4 & .. & 31.9 & 33.1 & 31.0 & 30.3 & 29.2 & 28.8 & .. \\
\hline Netherlands & 25.4 & 25.6 & 24.6 & 26.1 & 23.3 & 24.1 &.. & 60.3 & 61.9 & 62.2 & 61.1 & 54.7 & 51.8 & .. \\
\hline New Zealand & .. & .. &.. &.. &.. & .. &.. &.. &.. &.. &.. &.. &.. & .. \\
\hline Norway & 121.5 & 145.4 & 157.5 & 171.8 & 197.2 & 201.0 & 181.1 & 40.6 & 50.2 & 52.7 & 49.1 & 60.5 & 58.4 & 55.7 \\
\hline Poland & 33.0 & 32.7 & 33.8 & 34.6 & 35.5 & 34.7 & .. & 55.0 & 55.3 & 54.6 & 56.4 & 55.9 & 51.6 & .. \\
\hline Portugal & 31.9 & 30.8 & 28.4 & 29.0 & 29.1 & 27.0 & 27.4 & 66.5 & 68.0 & 70.6 & 74.0 & 73.1 & 71.1 & 75.2 \\
\hline Slovak Republic & 48.5 & 46.5 & 40.3 & 33.6 & 27.4 & 33.0 & .. & 50.2 & 48.2 & 47.0 & 38.5 & 34.0 & 32.4 & .. \\
\hline Spain & 20.0 & 18.5 & 18.7 & 20.4 & 22.2 & 23.2 & 24.0 & 60.3 & 55.4 & 53.4 & 50.6 & 46.2 & 42.1 & 47.0 \\
\hline Sweden & 53.9 & 56.5 & 58.8 & 63.8 & 68.6 & 68.0 &.. & 60.5 & 59.8 & 59.5 & 59.7 & 52.5 & 47.1 & .. \\
\hline Switzerland & 41.5 & 41.1 & 40.2 & 39.7 & 36.8 & .. &.. & 57.2 & 57.0 & 57.9 & 56.4 & 50.2 &.. & .. \\
\hline Turkey & .. &.. & .. & .. & .. & .. &.. & .. & .. & .. &.. & .. &.. & .. \\
\hline United Kingdom & 25.2 & 24.7 & 25.0 & 26.3 & 25.6 & 24.8 & .. & 48.8 & 48.5 & 50.7 & 53.5 & 53.3 & 53.8 & .. \\
\hline United States & 19.5 & 19.5 & 19.0 & 18.8 & 19.2 & 19.6 & 22.9 & 57.2 & 60.5 & 61.5 & 61.7 & 61.2 & 62.2 & 70.6 \\
\hline Euro area & .. & .. & .. &.. &.. & .. & .. & .. & .. & .. &.. & .. & .. & .. \\
\hline OECD-Total & .. & .. & .. & .. & .. & .. & .. & .. & .. &.. & & .. & & .. \\
\hline
\end{tabular}

Figure 20.1. Financial net worth of general government

Percentage of GDP, 2007

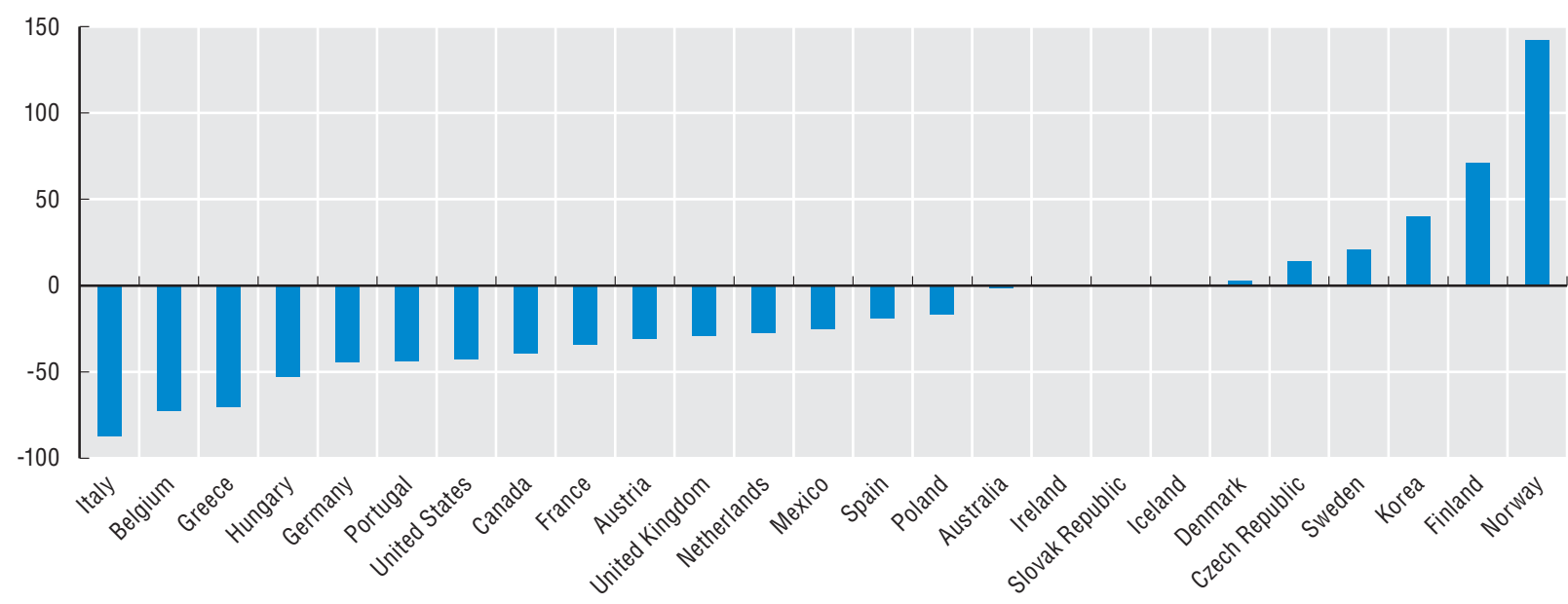

StatLink काISL http://dx.doi.org/10.1787/740437381684 

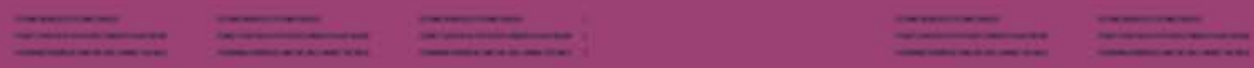

$\pm=$

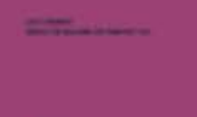

$-$
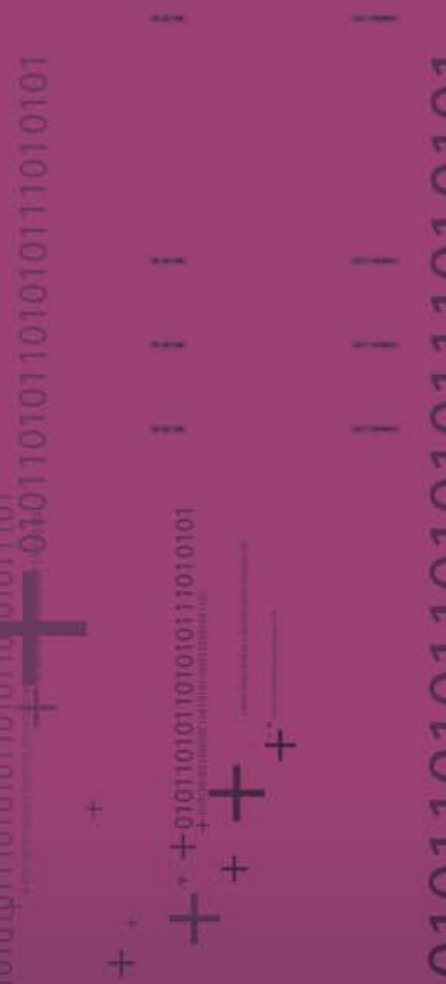

=2.
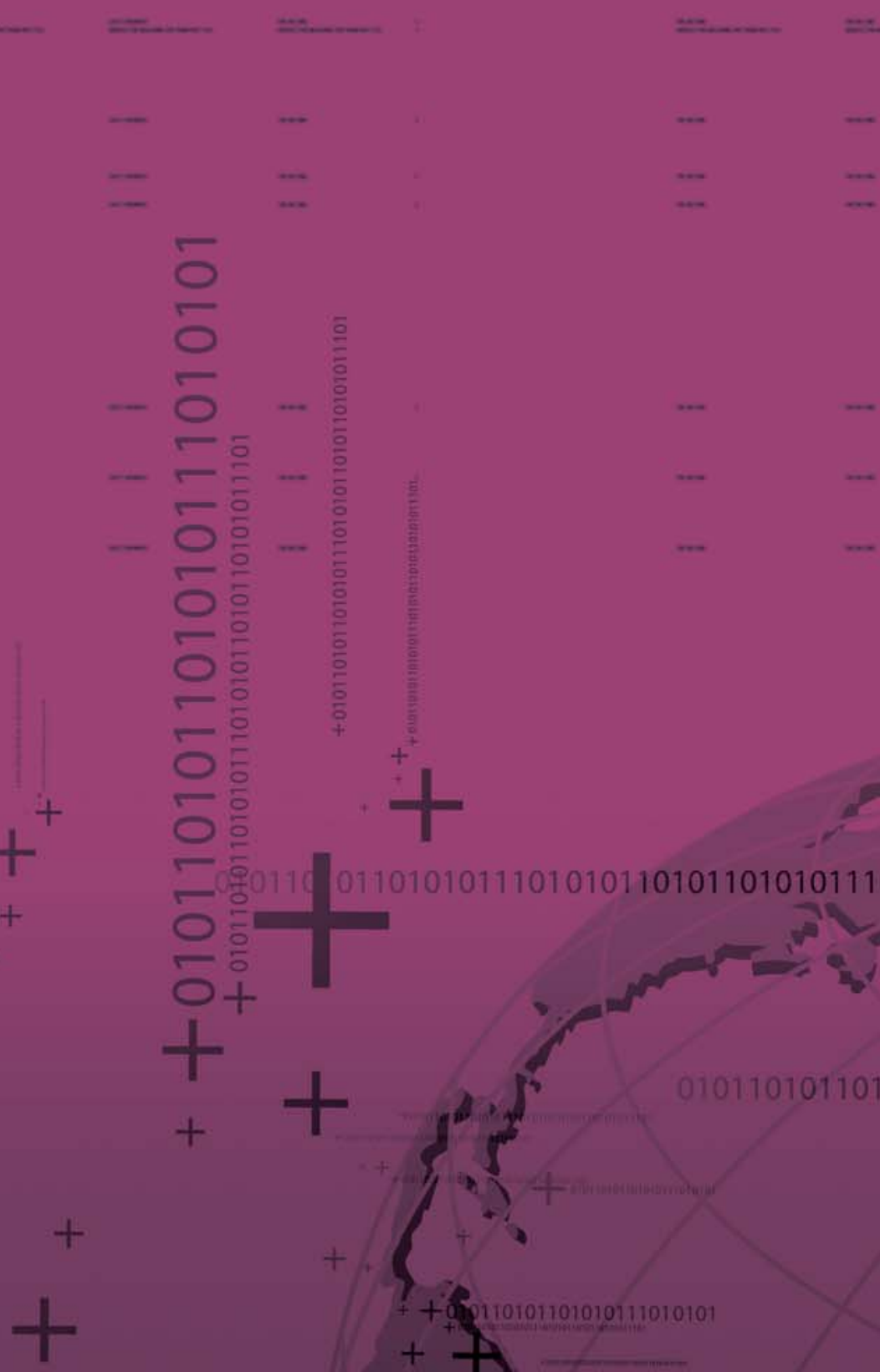

011010101110101011010110101011101
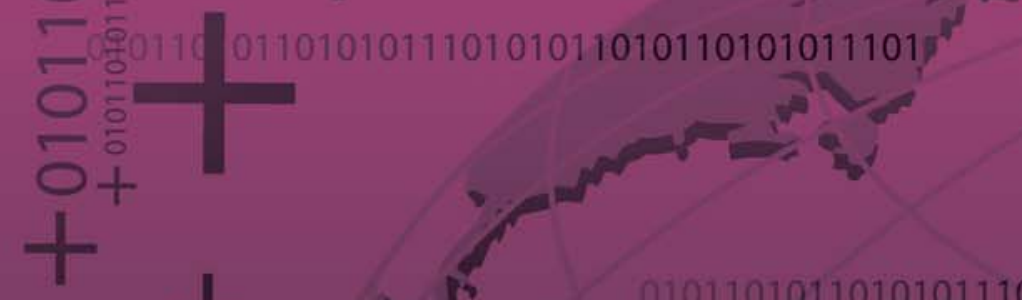


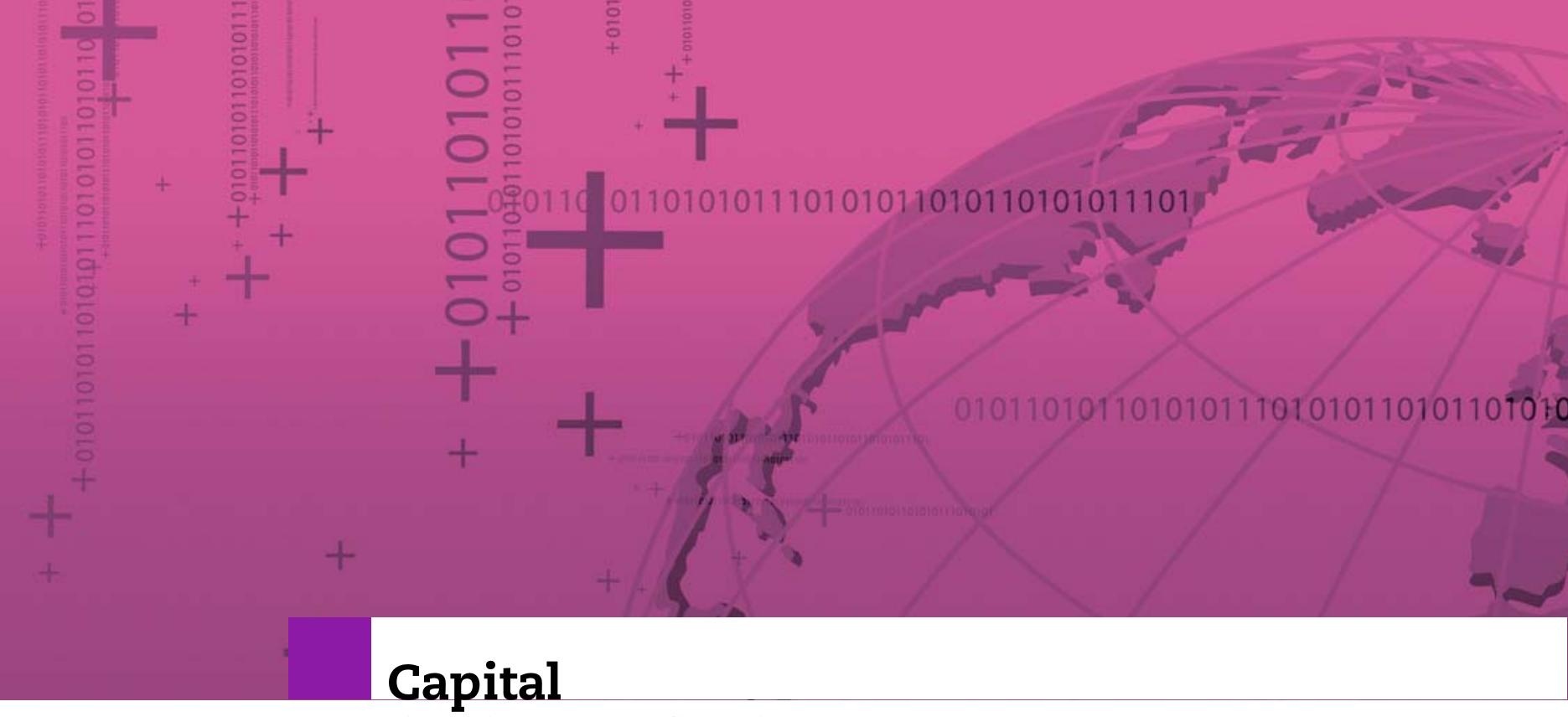

Financial and non-financial assets

21. Net capital stock

22. Consumption of fixed capital

23. Non-financial assets held by households

24. Financial assets held by households 


\section{Net capital stock}

Net capital stock reflects the market value of the stock of fixed assets in the economy and as such provides an important indication of overall wealth. It also forms an important input into the derivation of other statistical indicators, such as depreciation and, in some cases, capital services.

\section{Definition}

The stock of assets surviving from past periods, and corrected for depreciation is the net (or wealth) capital stock. The net stock is valued as if the capital good (used or new) were acquired on the date to which a balance sheet relates. The net stock is designed to reflect the wealth of the owner of the asset at a particular point in time.

The value of the net stock of non-financial produced fixed assets is usually estimated by the perpetual inventory method (PIM). The PIM cumulates past flows of GFCF in volume terms and corrects them for the retirement of assets and for their loss in value due to ageing, depreciation. Each annual investment is an addition to the stock, while each retirement or deterioration enters as a deduction.

Some countries also compute a measure of the gross capital stock which corresponds to the net stock before depreciation is taken into account. Thus, the gross stock only adjusts for retirements but otherwise treats every asset as if it were new.

It is also noteworthy that neither the net nor the gross stock are the conceptually correct measure to capture capital inputs into production - these are best reflected through measures of the flow of capital services (see Measuring Capital in "Further reading" for more information).

\section{Comparability}

Cross country comparability is driven by three major factors: i) the coverage of fixed assets ii) retirement and depreciation profiles used and iii) for those countries that use the PIM model, the length of time series available for GFCF by product.

OECD countries use various types of retirement and depreciation functions that may differ in shape and in regard to the average and maximum service lives for different types of assets. For example, some countries use linear depreciation profiles (corresponding to a constant amount of depreciation every period) and others use geometric profiles (corresponding to a constant rate of depreciation every period). However, the use of different parameters and profiles for depreciation does not in itself imply a lack of comparability. There may be very good reasons for these differences. For example, even if one could assume that the buildings in one country were exactly the same as another, one might expect a higher rate of depreciation in a country with extreme temperatures say.

An area where comparability is directly affected concerns the coverage of assets in estimates of net capital stock, and these are not always fully comparable across countries (see Section 12).

\section{Online database}

- OECD (2009), "Detailed national accounts: Fixed assets by activity and by type of product", OECD National Accounts Statistics (database), http://dx.doi.org/10.1787/data-00009-en.

\section{Further reading}

- OECD (2009), Measuring Capital - OECD Manual 2009: Second edition, OECD Publishing, http://dx.doi.org/10.1787/9789264068476-en.

- Lequiller, F. and D. Blades (2007), Understanding National Accounts, OECD Publishing, http://dx.doi.org/10.1787/9789264027657-en.

- OECD (2000), System of National Accounts, 1993 Glossary, OECD Publishing, http://dx.doi.org/10.1787/9789264180871-en.

- UN, OECD, IMF, Eurostat (eds.) (1993), System of National Accounts 1993, United Nations, Geneva, http://unstats.un.org/unsd/sna1993. 
Table 21.1. Net capital stock, volume

\begin{tabular}{|c|c|c|c|c|c|c|c|c|c|c|c|c|c|c|}
\hline & 1995 & 1996 & 1997 & 1998 & 1999 & 2000 & 2001 & 2002 & 2003 & 2004 & 2005 & 2006 & 2007 & 2008 \\
\hline Australia & 86.0 & 88.5 & 91.3 & 94.4 & 97.7 & 100.0 & 102.7 & 106.4 & 110.6 & 115.1 & 120.1 & 125.3 & 131.3 & .. \\
\hline Austria & 87.9 & 90.2 & 93.7 & 95.0 & 97.3 & 100.0 & 102.5 & 104.1 & 106.3 & 108.0 & 110.0 & 112.1 & 114.4 & .. \\
\hline Belgium & 90.4 & 92.0 & 93.8 & 95.7 & 97.8 & 100.0 & 102.0 & 103.7 & 105.1 & 106.9 & 108.9 & 111.0 & .. & .. \\
\hline Canada &.. & .. & .. &.. &.. & .. &.. &.. &.. & .. &.. &.. & .. & .. \\
\hline Czech Republic & 90.6 & 93.2 & 95.0 & 96.9 & 98.4 & 100.0 & 101.8 & 103.1 & 105.0 & 106.7 & 108.3 & 110.3 & 113.3 & .. \\
\hline Denmark & 94.3 & 95.3 & 96.2 & 97.5 & 98.9 & 100.0 & 101.5 & 102.7 & 103.8 & 104.7 & 105.8 & 107.0 & 109.2 & 111.7 \\
\hline Finland & 95.3 & 95.3 & 96.0 & 97.2 & 98.5 & 100.0 & 101.7 & 103.0 & 104.4 & 106.1 & 107.7 & 109.5 & .. & .. \\
\hline France & 89.8 & 91.5 & 93.2 & 95.2 & 97.5 & 100.0 & 102.5 & 104.7 & 106.9 & 109.2 & 111.7 & 114.4 & 117.4 & 120.4 \\
\hline Germany & 90.6 & 92.5 & 94.4 & 96.1 & 98.0 & 100.0 & 102.1 & 103.7 & 104.7 & 105.7 & 106.7 & 107.6 & 109.1 & .. \\
\hline Greece & .. & .. & .. & .. & .. & .. & .. & .. & .. & .. & .. & .. & .. & .. \\
\hline Hungary & .. & .. &.. & .. & .. & 100.0 & 99.9 & 101.0 & 101.7 & 102.8 & 104.4 & 106.1 & 107.7 & .. \\
\hline Iceland &.. & .. &.. &.. &.. & .. & .. & .. & .. & .. & .. & .. & .. & .. \\
\hline Ireland & .. & .. & .. & .. & .. & .. &.. &.. & .. & .. &.. & .. &.. & .. \\
\hline Italy & .. & .. & .. & .. & 98.0 & 100.0 & 101.9 & 104.0 & 105.8 & 107.7 & 109.5 & 111.3 & 113.2 & .. \\
\hline Japan &.. & .. &.. &.. & .. &.. &.. &.. & .. &.. &.. &.. &.. & .. \\
\hline Korea & .. & .. &.. &.. & .. & .. &.. & .. & .. &.. &.. &.. &.. & .. \\
\hline Luxembourg &.. & .. &.. &.. &.. &.. &.. &.. & .. &.. &.. &.. &.. & .. \\
\hline Mexico & .. & .. & .. & .. & .. & .. & .. & .. & .. & .. &.. & .. &.. & .. \\
\hline Netherlands & 88.8 & 90.6 & 92.8 & 95.1 & 97.7 & 100.0 & 102.1 & 103.8 & 105.3 & 106.5 & 108.0 & 109.8 & 111.9 & 114.2 \\
\hline New Zealand & .. & .. & .. & .. & .. & .. & .. & .. & .. & .. & .. & .. & .. & .. \\
\hline Norway & 88.6 & 90.3 & 92.8 & 95.6 & 98.0 & 100.0 & 101.7 & 103.0 & 104.4 & 106.3 & 109.0 & 112.6 & 116.7 & 121.0 \\
\hline Poland & .. & .. & .. & .. & .. & 100.0 & 108.2 & 114.6 & 118.5 & 119.4 & 123.0 & 126.4 & .. & .. \\
\hline Portugal &.. &.. &.. &.. &.. & .. &.. &.. & .. &.. & .. & .. &.. & .. \\
\hline Slovak Republic & .. &.. & .. &.. & .. & .. &.. & .. & .. &.. &.. & .. & .. & .. \\
\hline Spain & .. &.. & .. &.. &.. & .. &.. & .. & .. & .. & .. & .. & .. & .. \\
\hline Sweden &.. &.. & .. &.. &.. & 100.0 & 101.9 & 103.7 & 105.6 & 107.1 & 108.8 & 110.9 & .. & .. \\
\hline Switzerland & .. &.. & .. &.. & .. & .. &.. & .. & .. & .. & .. & .. & .. & .. \\
\hline Turkey &.. &.. & .. &.. &.. & .. &.. & .. & .. &.. & .. & .. &.. & .. \\
\hline United Kingdom & .. &.. & .. & .. &.. & .. & .. & .. & .. & .. & .. & .. & .. & .. \\
\hline United States & 85.7 & 88.2 & 90.8 & 93.7 & 96.8 & 100.0 & 102.7 & 105.0 & 107.4 & 109.9 & 112.5 & 115.3 & 117.7 & .. \\
\hline Euro area & .. & .. & .. & .. & .. & .. & .. & .. & .. & .. &.. & .. & .. & .. \\
\hline OECD-Total & .. & .. & .. & .. & .. & .. & .. & .. & .. & .. & .. & .. & .. & .. \\
\hline
\end{tabular}

Figure 21.1. Net capital stock, volume

Year $2000=100,2006$

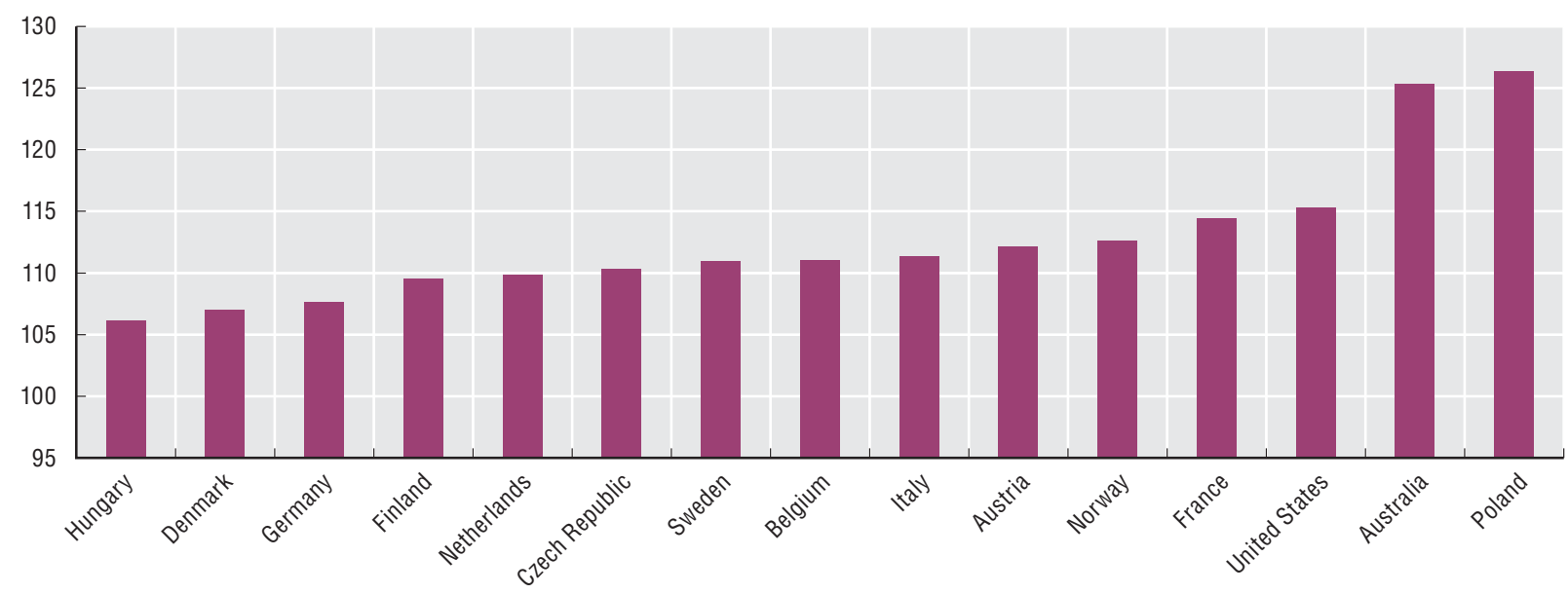




\section{Consumption of fixed capital}

Economically, consumption of fixed capital, (depreciation), is best described as a deduction from income to account for the loss in capital value owing to the use of capital goods in production. Its primary importance in an accounting sense is in its use as the "netting" component in estimates of net domestic product, etc., as described in earlier sections, and, so, in its ability to permit analyses that are closer to a welfare perspective than gross measures. It also constitutes one part of the costs of capital services and so plays a role in productivity measurement. Moreover it has a direct impact on GDP because estimates of non-market value-added explicitly include a component for depreciation.

\section{Definition}

The 1993 System of National Accounts defines consumption of fixed capital, (depreciation), in the following way:

Consumption of fixed capital is the decline, during the course of the accounting period, in the current value of the stock of fixed assets owned and used by a producer as a result of physical deterioration, normal obsolescence or normal accidental damage. [...] Losses due to war or to major natural disasters that occur very infrequently [...] are not included under consumption of fixed capital. [...]

It further states that:

The values of the assets lost in these ways are recorded in the other changes in the volume of assets accounts. [...] Consumption of fixed capital is defined in the System in a way that is intended to be theoretically appropriate and relevant for purposes of economic analysis. Its value may deviate considerably from depreciation as recorded in business accounts or as allowed for taxation purposes, especially when there is inflation.

Depreciation in business accounts is typically measured differently from depreciation in the national accounts. The latter measures depreciation by applying a "depreciation coefficient" to the current value of each capital asset whereas company accountants typically apply a depreciation coefficient to the value of the capital good at its original purchase price ("historic cost"). When the prices of capital goods rise, the difference can therefore be significant.

With the increasing importance of high-tech capital goods that undergo rapid technical change, there has been renewed discussion about the measurement of depreciation. In particular, some have argued that depreciation should incorporate expected real holding losses on the grounds that this is the appropriate way of capturing expected obsolescence. Others have come to a different conclusion, and draw a distinction between value changes of an asset due to ageing (which they identify with depreciation) and value changes due to overall price changes of the group of capital goods; which corresponds to the position of the SNA and, indeed, the practice of statistical offices.

\section{Comparability}

Like estimates of net capital stock, the international comparability of estimates of depreciation are dependent on i) the coverage of fixed assets ii) the assumptions used for service lives and rates of depreciation and iii) the time series of GFCF estimates. Although the comparability of points i) and iii) are generally good across countries (see also Section 12), the assumptions on service lives and depreciation rates differ across countries, although as described in Section 21, there are often sound reasons for such differences, reflecting an economic reality.

\section{Source}

- OECD (2009), National Accounts of OECD Countries 2009, Volumes I, Main Aggregates, OECD Publishing,

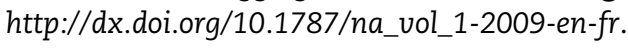

\section{Online database}

- OECD (2009), "Aggregate national accounts: gross domestic product", OECD National Accounts Statistics (database), http://dx.doi.org/10.1787/data-00001-en.

\section{Further reading}

- OECD (2009), Measuring Capital - OECD Manual 2009: Second edition, OECD Publishing, http://dx.doi.org/10.1787/9789264068476-en.

- Lequiller, F. and D. Blades (2007), Understanding National Accounts, OECD Publishing, http://dx.doi.org/10.1787/9789264027657-en.

- OECD (2000), System of National Accounts, 1993 Glossary, OECD Publishing, http://dx.doi.org/10.1787/9789264180871-en.

- UN, OECD, IMF, Eurostat (eds.) (1993), System of National Accounts 1993, United Nations, Geneva, http://unstats.un.org/unsd/sna1993. 
Table 22.1. Consumption of fixed capital

Percentage of GDP

\begin{tabular}{|c|c|c|c|c|c|c|c|c|c|c|c|c|c|c|}
\hline & 1995 & 1996 & 1997 & 1998 & 1999 & 2000 & 2001 & 2002 & 2003 & 2004 & 2005 & 2006 & 2007 & 2008 \\
\hline Australia & 15.7 & 15.3 & 15.5 & 15.5 & 15.6 & 15.5 & 15.7 & 15.6 & 15.3 & 15.0 & 15.1 & 15.2 & 15.2 & $15.2 \mathrm{e}$ \\
\hline Austria & 14.8 & 14.8 & 15.1 & 15.1 & 15.1 & 15.1 & 15.4 & 15.5 & 15.6 & 15.5 & 15.4 & 15.3 & 15.2 & 15.3 \\
\hline Belgium & 14.1 & 14.6 & 14.6 & 14.8 & 15.0 & 14.9 & 15.4 & 15.4 & 15.7 & 15.5 & 15.3 & 15.0 & 15.1 & 15.6 \\
\hline Canada & 13.0 & 13.2 & 13.2 & 13.4 & 13.1 & 12.8 & 13.3 & 13.5 & 13.3 & 13.0 & 12.8 & 12.8 & 12.7 & $12.9 \mathrm{e}$ \\
\hline Czech Republic & 20.2 & 19.3 & 20.1 & 19.9 & 20.3 & 20.6 & 20.3 & 20.0 & 19.7 & 19.1 & 18.6 & 17.9 & 17.3 & 17.3 \\
\hline Denmark & 15.5 & 15.6 & 15.7 & 15.9 & 16.1 & 15.8 & 16.1 & 16.2 & 16.5 & 16.4 & 15.9 & 15.7 & 15.9 & 16.3 \\
\hline Finland & 17.4 & 17.1 & 16.3 & 15.6 & 15.5 & 15.4 & 15.2 & 14.8 & 14.7 & 14.7 & 15.1 & 14.9 & 15.1 & 15.5 \\
\hline France & 12.3 & 12.4 & 12.3 & 12.1 & 12.2 & 12.4 & 12.6 & 12.7 & 12.8 & 12.9 & 13.1 & 13.3 & 13.3 & 13.8 \\
\hline Germany & 14.6 & 14.7 & 14.8 & 14.8 & 14.8 & 15.0 & 15.0 & 15.0 & 14.9 & 14.9 & 15.0 & 14.8 & 14.8 & 14.7 \\
\hline Greece & $11.5 \mathrm{e}$ & $11.6 \mathrm{e}$ & $11.4 \mathrm{e}$ & $11.5 \mathrm{e}$ & $11.5 \mathrm{e}$ & 11.4 & 11.6 & 11.5 & 12.5 & 12.3 & 12.3 & 12.1 & 12.0 & 12.2 \\
\hline Hungary & 18.9 & 19.2 & 18.5 & 17.9 & 18.4 & 17.9 & 17.1 & 15.8 & 15.3 & 14.6 & 14.6 & 14.8 & 14.6 & 14.9 \\
\hline Iceland & 14.2 & 13.2 & 12.1 & 11.5 & 11.9 & 11.9 & 12.1 & 12.1 & 12.0 & 11.6 & 11.7 & 12.5 & 13.1 & 14.9 \\
\hline Ireland & 9.9 & 9.9 & 9.8 & 9.4 & 9.7 & 10.1 & 10.1 & 10.2 & 9.9 & 10.0 & 10.3 & 9.8 & 9.4 & 9.7 \\
\hline Italy & 14.5 & 14.4 & 14.5 & 14.5 & 14.6 & 14.6 & 14.7 & 15.0 & 15.1 & 15.2 & 15.5 & 15.6 & 15.7 & 16.2 \\
\hline Japan & $18.5 \mathrm{e}$ & 18.7 & 18.7 & 19.4 & 19.5 & 19.7 & 20.2 & 20.2 & 20.9 & 21.1 & 20.8 & 20.9 & 20.8 & $21.0 \mathrm{e}$ \\
\hline Korea & $11.5 \mathrm{e}$ & $12.1 \mathrm{e}$ & $12.9 \mathrm{e}$ & $14.7 \mathrm{e}$ & $14.3 \mathrm{e}$ & 13.8 & 13.5 & 12.9 & 13.0 & 12.9 & 13.2 & 13.3 & 13.2 & 13.3 \\
\hline Luxembourg & 13.5 & 13.7 & 13.7 & 13.7 & 13.0 & 13.2 & 13.6 & 12.1 & 11.3 & 11.7 & 11.1 & 10.9 & 10.6 & 10.5 \\
\hline Mexico & $10.3 \mathrm{e}$ & $9.7 \mathrm{e}$ & $9.2 \mathrm{e}$ & $9.3 \mathrm{e}$ & $9.1 \mathrm{e}$ & $8.6 \mathrm{e}$ & $8.8 \mathrm{e}$ & $8.8 \mathrm{e}$ & 9.0 & 8.9 & 8.7 & 8.5 & 8.7 & $8.7 \mathrm{e}$ \\
\hline Netherlands & 14.8 & 14.8 & 14.4 & 14.5 & 14.6 & 14.7 & 14.7 & 14.9 & 15.0 & 15.0 & 14.8 & 14.6 & 14.4 & 14.4 \\
\hline New Zealand & 14.0 & 13.9 & 13.9 & 14.2 & 14.1 & 14.2 & 13.8 & 13.7 & 13.5 & 13.6 & 13.9 & 14.2 & 14.1 & $14.1 \mathrm{e}$ \\
\hline Norway & 15.8 & 15.1 & 14.8 & 15.5 & 15.0 & 13.5 & 13.9 & 14.2 & 14.0 & 13.5 & 12.7 & 12.3 & 12.6 & 12.3 \\
\hline Poland & 14.1 & 14.1 & 13.7 & 13.5 & 13.6 & 13.3 & 13.6 & 13.6 & 13.7 & 13.1 & 12.9 & 12.7 & 12.1 & 11.4 \\
\hline Portugal & 15.7 & 15.6 & 15.4 & 15.2 & 15.2 & 15.7 & 15.8 & 16.1 & 16.4 & 16.4 & 16.6 & 16.5 & 16.5 & 17.0 \\
\hline Slovak Republic & 20.4 & 20.5 & 20.6 & 20.3 & 20.9 & 20.7 & 20.7 & 20.7 & 20.5 & 19.7 & 19.3 & 18.2 & 17.0 & 16.2 \\
\hline Spain & 13.0 & 13.1 & 13.2 & 12.9 & 13.2 & 13.7 & 13.8 & 14.1 & 14.4 & 14.9 & 15.3 & 15.6 & 15.7 & 16.2 \\
\hline Sweden & 11.2 & 11.4 & 11.5 & 11.7 & 12.1 & 12.5 & 13.1 & 13.0 & 12.6 & 12.3 & 12.3 & 12.2 & 12.2 & 12.8 \\
\hline Switzerland & 17.4 & 17.3 & 17.0 & 16.9 & 17.4 & 17.6 & 18.2 & 18.3 & 18.3 & 18.0 & 17.9 & 17.6 & 17.3 & 17.4 \\
\hline Turkey & .. & .. & .. & .. & .. & .. & .. & .. & .. & .. & .. & .. & .. & .. \\
\hline United Kingdom & 12.2 & 11.9 & 11.5 & 11.3 & 11.4 & 11.4 & 11.3 & 11.3 & 11.0 & 11.3 & 11.1 & 11.2 & 11.3 & 11.4 \\
\hline United States & 11.1 & 11.0 & 11.0 & 11.1 & 11.2 & 11.4 & 11.8 & 11.8 & 11.7 & 11.7 & 11.8 & 12.0 & 12.1 & 12.4 \\
\hline Euro area & 14.0 & 14.0 & 14.0 & 13.9 & 14.0 & 14.1 & 14.2 & 14.3 & 14.4 & 14.4 & 14.6 & 14.6 & 14.6 & 14.9 \\
\hline OECD-Total & $13.2 \mathrm{e}$ & $13.2 \mathrm{e}$ & $13.1 \mathrm{e}$ & $13.2 \mathrm{e}$ & $13.3 \mathrm{e}$ & $13.3 \mathrm{e}$ & $13.6 \mathrm{e}$ & $13.7 \mathrm{e}$ & $13.7 \mathrm{e}$ & $13.6 \mathrm{e}$ & $13.6 \mathrm{e}$ & $13.6 \mathrm{e}$ & $13.7 \mathrm{e}$ & $13.9 \mathrm{e}$ \\
\hline
\end{tabular}

\section{Figure 22.1. Consumption of fixed capital}

Percentage of GDP, 2008

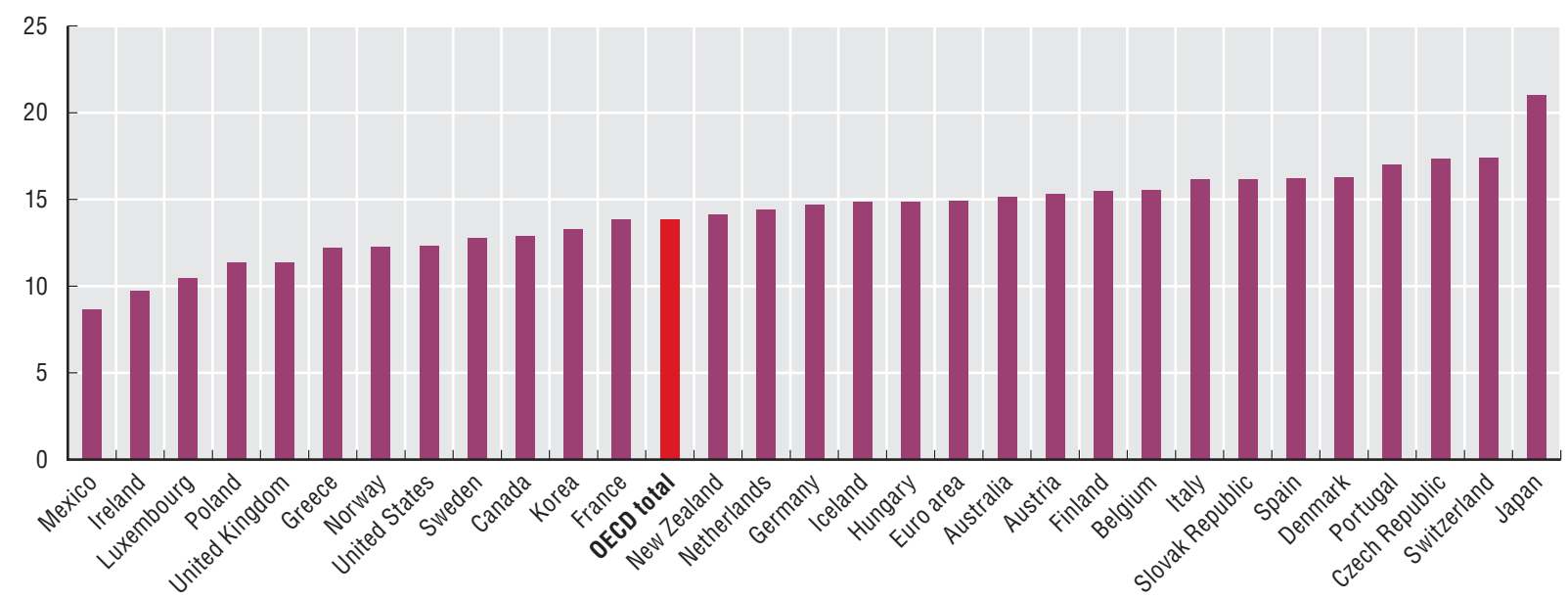

StatLink काISL http://dx.doi.org/10.1787/740481157101 


\section{Non-financial assets held by households}

Non-financial assets held by households reflect the assets owned by unincorporated household enterprises and dwellings owned by households, with the latter component forming by far the bulk of nonfinancial assets held by households. They form an important part of overall wealth and can provide an important additional source of revenue; either through their sale or refinancing, or as income via rentals of residential property for example. Estimates of non-financial assets held by households also play an important role in economic analyses, such as studies of asset bubbles, and analyses of living standards.

\section{Definition}

Non-financial assets held by households include in theory both produced and non-produced nonfinancial assets and therefore include: Dwellings and other buildings and structures and land improvements; Machinery and equipment including livestock; and even intellectual property products, such as software and literary originals, and non-produced assets such as land and taxi-licenses. In practice dwellings form by far the most significant component.

Except for dwellings, only those assets owned by household unincorporated enterprises, and used in production, are included as non-financial assets. For example a car used by a household purely for household transport is not a nonfinancial asset whereas a car used by a selfemployed taxi driver is.

Non-financial assets are valued in the balance sheets at the market prices of the time of the balance sheet, and are recorded net of depreciation.

\section{Comparability}

Information on non-financial assets held by households typically relies on household based surveys and so the quality of such information, except for that per- taining to dwellings and land, is generally of lower quality than it is for similar information collected on incorporated businesses.

Moreover, in practice, countries use a variety of methods to differentiate between the value of dwellings and the land on which the dwellings sit, meaning that comparisons of these subcomponents across countries are challenging. Some countries, for example the United Kingdom, include the value of land under dwellings within the figures for dwellings. This matters not only for international comparability, and indeed temporal comparisons, but also because dwellings, as produced assets depreciate whereas (most) land, as a non-produced asset, does not. A particular challenge arises from capturing quality change and quality differences in the housing stock and valuing it accordingly.

The caveats above, pertaining to the distinction between land and dwellings, mean that users should be particularly careful in using the figures on the right in making international comparisons. The OECD Statistics Directorate will be working with national statistics institutes so that future versions of this publication reflect a greater degree of international comparability

\section{Online database}

- OECD (2009), "Detailed national accounts: balance sheets for non-financial assets", OECD National Accounts Statistics (database), http://dx.doi.org/10.1787/data-00368-en.

\section{Further reading}

- Lequiller, F. and D. Blades (2007), Understanding National Accounts, OECD Publishing, http://dx.doi.org/10.1787/9789264027657-en.

- OECD (2000), System of National Accounts, 1993 Glossary, OECD Publishing, http://dx.doi.org/10.1787/9789264180871-en.

- UN, OECD, IMF, Eurostat (eds.) (1993), System of National Accounts 1993, United Nations, Geneva, http://unstats.un.org/unsd/sna1993. 
23. Non-financial assets held by households

Table 23.1. Non-financial assets of households per capita

US dollars at current PPPs

\begin{tabular}{|c|c|c|c|c|c|c|c|c|c|c|c|c|}
\hline & \multicolumn{4}{|c|}{ Dwellings } & \multicolumn{4}{|c|}{ Land } & \multicolumn{4}{|c|}{ Other } \\
\hline & 2004 & 2005 & 2006 & 2007 & 2004 & 2005 & 2006 & 2007 & 2004 & 2005 & 2006 & 2007 \\
\hline Australia & 37521 & 39353 & 41292 & 43817 & 69956 & 75469 & 81307 & 80974 & 8186 & 8615 & 9008 & 9579 \\
\hline Austria & .. & .. & .. &.. &.. &.. & .. & .. & .. & .. &.. & .. \\
\hline Belgium & 30055 & 31612 & 34135 & 36519 & .. & .. & .. & .. & .. & .. & .. & .. \\
\hline Canada & 26702 & 29033 & 32385 & 34598 & 21304 & 24022 & 26962 & 29675 & 1524 & 1565 & 1576 & 1587 \\
\hline Czech Republic & 14840 & 15452 & 16203 & 17398 & 975 & 1013 & 1516 & 1709 & 3667 & 4328 & 4833 & 5080 \\
\hline Denmark & 25551 & 25458 & 26418 & 27874 & .. & .. & .. & .. & .. & .. & .. & .. \\
\hline Finland & 23542 & 25295 & 26878 & 29020 & .. & .. & .. & .. & .. & .. &.. & .. \\
\hline France & 39404 & 43371 & 46030 & 50727 & 41283 & 51889 & 59907 & 63350 & 6430 & 6915 & 7197 & 7495 \\
\hline Germany & 38918 & 41615 & 42988 & 46110 & .. & .. & .. & .. &.. & .. & .. & .. \\
\hline Greece & .. & .. & .. & .. &.. & .. &.. & .. & .. & .. & .. & .. \\
\hline Hungary & 16850 & 17569 & 18809 & 19778 & .. & .. & .. & .. & .. & .. & .. & .. \\
\hline Iceland & .. & .. & .. & .. & .. & .. & .. & .. & .. & .. & .. & .. \\
\hline Ireland &.. &.. & .. & .. & .. & .. & .. & .. & .. & .. & .. & .. \\
\hline Italy & .. & .. & .. &. & .. & .. & .. & .. & .. & .. &.. & .. \\
\hline Japan &.. & .. & .. & .. & 46659 & 47437 & 50288 & 52488 & .. & .. &.. & .. \\
\hline Korea & .. & .. & .. & .. & .. & .. & .. & .. & .. & .. & .. & .. \\
\hline Luxembourg & 57306 & 57110 & 58888 & 60585 & .. & .. & .. & .. & .. & .. &.. & .. \\
\hline Mexico & .. & .. & .. & .. & .. & .. &. & .. & .. & .. & .. & .. \\
\hline Netherlands & 38500 & 41119 & 44185 & 46684 & .. &.. & .. & .. & .. & .. & .. & .. \\
\hline New Zealand & .. & .. & .. & .. & .. &.. & .. & .. & .. & .. &.. & .. \\
\hline Norway & 35706 & 38623 & 41506 & .. & .. & .. &.. &.. & .. & .. & .. & .. \\
\hline Poland & 4598 & 5065 & 5617 & .. & .. & .. & .. & .. & .. & .. & .. & .. \\
\hline Portugal & .. & .. & .. & .. & .. & .. & .. & .. & .. & .. &.. & .. \\
\hline Slovak Republic & 20809 & 22462 & 23702 & 25136 & .. & .. & .. & .. & .. & .. & .. & .. \\
\hline Spain & .. & .. & .. & .. &.. & .. & .. & .. & .. & .. & .. & .. \\
\hline Sweden & 18271 & 19039 & 21671 & .. & .. & .. & .. & .. & .. & .. & .. & .. \\
\hline Switzerland & .. & .. & .. & .. & .. & .. & .. & .. & .. & .. & .. & .. \\
\hline Turkey & .. & .. & .. & .. & .. & .. & .. & .. & .. & .. & .. & .. \\
\hline United Kingdom & 85163 & 87058 & 95379 & 103476 & .. & .. & .. & .. & 17999 & 18551 & 20138 & 21420 \\
\hline United States & 45106 & 49915 & 52878 & 53054 & .. & .. & .. & .. & .. & .. & .. & .. \\
\hline Euro area & .. & .. & .. & .. & .. & .. & .. & .. & .. & .. & .. & .. \\
\hline OECD-Total & .. & .. & .. & .. & .. & .. & .. & .. & .. & .. & .. & .. \\
\hline
\end{tabular}




\section{Financial assets held by households}

Financial assets held by households include cash, shares, pension funds etc and form an important part of overall wealth and an important source of revenue; either through their sale or refinancing, via pensions, or other property income via interest and dividends say. Data on financial assets held by households play an important role in economic analyses, such as studies of asset bubbles and analyses of welfare.

\section{Definition}

Financial assets held by households include: currency and deposits; securities other than shares; loans; shares and other equity; net equity of households in life insurance reserves; net equity of households in pension funds; prepayments of premiums and reserves against outstanding claims; and other accounts receivable.

Most of the asset classes above are self-explanatory but in the following cases a few additional elaborations are helpful.

Life insurance reserves and pension funds are typically managed by institutions outside of the household sector but the reserves and funds are considered the property of the household sector.

Non-life insurance is treated differently however and only the prepayment of premiums made by households and outstanding claims payable to households are considered as financial assets of the households themselves.

Other accounts receivable typically reflect payments due to households not included elsewhere, such as tax reimbursements, outstanding wages and salaries and often, depending on national practice, interest accruing on deposits and loans that is not capitalized in the underlying asset.

In practice the bulk of financial assets held by households reflects currency and deposits, securities, shares and equity and net equity in life insurance reserves and pension funds.

An important additional item relating to household financial assets, concerns contingencies, in particular, entitlements of households to pensions from unfunded schemes, such as pay as you go social security schemes. In these cases no actual financial reserves hypothecated to a pension fund exist and, so, no financial assets are recorded to the households sector (see Annex B for changes in the 2008 SNA).

\section{Comparability}

All countries follow the 1993 SNA. But data is not always available for all asset-types or not separately identifiable. As such considerable care is needed when making cross country comparisons, not only of totals, but especially of sub-totals.

The estimates shown in the tables and charts that follow present statistics on a non-consolidated basis (except for Australia).

\section{Source}

- OECD (2008), National Accounts of OECD Countries 2008, Volume IIIb, Financial Balance Sheets: Stocks, OECD Publishing, http://dx.doi.org/10.1787/na_vol_3b-2008-en-fr.

\section{Online databases}

- OECD (2009), "Financial balance sheets: non-consolidated stocks", OECD National Accounts Statistics (database), http://dx.doi.org/10.1787/data-00025-en.

- OECD, " Financial balance sheets : consolidated stocks ", OECD National Accounts Statistics (database), http://dx.doi.org/10.1787/data-00024-en.

\section{Further reading}

- Lequiller, F. and D. Blades (2007), Understanding National Accounts, OECD Publishing, http://dx.doi.org/10.1787/9789264027657-en.

- OECD (2000), System of National Accounts, 1993 Glossary, OECD Publishing, http://dx.doi.org/10.1787/9789264180871-en.

- UN, OECD, IMF, Eurostat (eds.) (1993), System of National Accounts 1993, United Nations, Geneva, http://unstats.un.org/unsd/sna1993. 
CAPITAL

24. Financial assets held by households

Table 24.1. Financial assets of households by type of assets

Percentage of total assets

\begin{tabular}{|c|c|c|c|c|c|c|c|c|c|c|c|c|}
\hline & \multicolumn{2}{|c|}{ Currency and deposits } & \multicolumn{2}{|c|}{ Securities other than shares } & \multicolumn{2}{|c|}{ Loans } & \multicolumn{2}{|c|}{ Shares and other equity } & \multicolumn{2}{|c|}{ Insurance technical reserves } & \multicolumn{2}{|c|}{ Other accounts } \\
\hline & 1997 & 2007 & 1997 & 2007 & 1997 & 2007 & 1997 & 2007 & 1997 & 2007 & 1997 & 2007 \\
\hline Australia & 25.1 & 20.0 & 2.4 & 0.5 & 1.1 & 0.9 & 15.2 & 17.8 & 55.2 & 59.2 & 1.1 & 1.7 \\
\hline Austria & 55.6 & 47.7 & 9.0 & 8.1 & 0.0 & 0.1 & 20.2 & 22.5 & 15.2 & 20.6 & 0.0 & 1.0 \\
\hline Belgium & 28.0 & 29.3 & 26.2 & 7.6 & 0.0 & 0.0 & 31.0 & 38.6 & 10.9 & 23.3 & 4.0 & 1.2 \\
\hline Canada & 22.0 & 19.3 & 6.4 & 2.2 & 1.2 & 0.3 & 28.0 & 38.4 & 35.8 & 36.3 & 6.6 & 3.5 \\
\hline Czech Republic & 58.4 & 56.0 & 0.2 & 0.3 & 0.0 & 0.0 & 27.5 & 21.8 & 7.3 & 14.6 & 6.6 & 7.4 \\
\hline Denmark & 23.4 & 21.2 & 11.5 & 5.1 & 0.0 & 0.0 & 18.3 & 29.5 & 44.8 & 43.1 & 1.9 & 1.1 \\
\hline Finland & 48.4 & 32.4 & 3.6 & 1.8 & 0.3 & 0.1 & 31.7 & 42.8 & 15.3 & 20.6 & 0.7 & 2.4 \\
\hline France & 39.3 & 29.4 & 3.9 & 1.6 & 1.9 & 0.7 & 24.4 & 26.7 & 27.8 & 37.9 & 2.8 & 3.8 \\
\hline Germany & 40.9 & 35.5 & 8.0 & 7.3 & 0.0 & 0.0 & 22.4 & 25.1 & 27.6 & 31.3 & 1.2 & 0.9 \\
\hline Greece & 51.4 & 50.9 & 10.4 & 9.1 & 0.0 & 0.0 & 28.8 & 33.1 & 2.0 & 3.0 & 7.4 & 3.9 \\
\hline Hungary & 48.5 & 34.5 & 8.7 & 4.8 & 1.3 & 0.8 & 31.6 & 37.4 & 5.2 & 18.7 & 4.8 & 3.9 \\
\hline Iceland & .. & .. & .. & .. & .. & .. &.. & .. & .. & .. & .. & .. \\
\hline Ireland & .. & 32.1 & .. & 0.0 & .. & 0.0 &.. & 25.9 & .. & 41.1 & .. & 0.9 \\
\hline Italy & 31.1 & 26.7 & 25.4 & 20.0 & 0.3 & 0.4 & 29.8 & 33.7 & 9.8 & 16.5 & 3.6 & 2.8 \\
\hline Japan & 53.4 & .. & 5.8 & .. & 0.0 & .. & 9.0 &.. & 26.8 & .. & 5.0 & .. \\
\hline Korea & .. & 42.9 & .. & 12.4 & .. & 0.0 & .. & 21.2 & .. & 20.0 & .. & 3.6 \\
\hline Luxembourg & .. & .. & .. & .. & .. & .. & .. &.. & .. & .. & .. & .. \\
\hline Mexico & 28.0 & 7.0 & 10.3 & 66.9 & 0.0 & 0.0 & 59.8 & 24.5 & 2.0 & 1.7 & 0.0 & 0.0 \\
\hline Netherlands & 19.6 & 21.8 & 2.8 & 3.6 & 0.2 & 0.2 & 24.3 & 15.1 & 53.1 & 59.4 & 0.0 & 0.0 \\
\hline New Zealand & .. & .. & .. &.. & .. & .. & .. & .. & .. & .. & .. & .. \\
\hline Norway & 34.5 & 30.4 & 0.6 & 1.0 & 0.8 & 2.7 & 16.7 & 16.5 & 37.8 & 37.6 & 9.6 & 12.0 \\
\hline Poland & 65.4 & 38.6 & 1.6 & 0.5 & 0.0 & 1.1 & 17.7 & 30.2 & 8.2 & 24.7 & 7.2 & 4.8 \\
\hline Portugal & 37.5 & 34.0 & 0.9 & 5.2 & 13.0 & 6.6 & 33.4 & 34.2 & 10.2 & 17.6 & 5.0 & 2.4 \\
\hline Slovak Republic & 82.5 & 58.2 & 6.2 & 1.6 & 0.0 & 0.0 & 3.4 & 12.3 & 5.5 & 18.9 & 2.4 & 9.0 \\
\hline Spain & 41.0 & 38.2 & 2.8 & 2.8 & 0.0 & 0.0 & 41.9 & 42.3 & 11.4 & 13.5 & 3.0 & 3.2 \\
\hline Sweden & 21.6 & 18.9 & 6.8 & 2.7 & 0.8 & 0.2 & 39.2 & 40.1 & 31.4 & 37.9 & 0.2 & 0.2 \\
\hline Switzerland & .. & 23.9 & .. & 9.0 & .. & .. & .. & 24.9 & .. & 42.3 & .. & 0.0 \\
\hline Turkey & .. &.. & .. &.. & .. & .. & .. & .. & .. & .. & .. & .. \\
\hline United Kingdom & 21.5 & 26.6 & 2.3 & 0.5 & 0.3 & 0.1 & 21.2 & 15.7 & 52.0 & 53.7 & 2.8 & 3.4 \\
\hline United States & 11.5 & 12.1 & 8.6 & 7.6 & 1.2 & 2.0 & 47.3 & 47.7 & 31.4 & 30.7 & 0.0 & 0.0 \\
\hline Euro area & .. &.. &.. &.. & .. &. & .. &.. & .. & .. & .. & .. \\
\hline OECD-Total & .. &.. & .. &.. & .. & .. & .. &.. & .. & .. & .. & .. \\
\hline
\end{tabular}

Figure 24.1. Financial assets of households per capita

US dollars at current PPPs

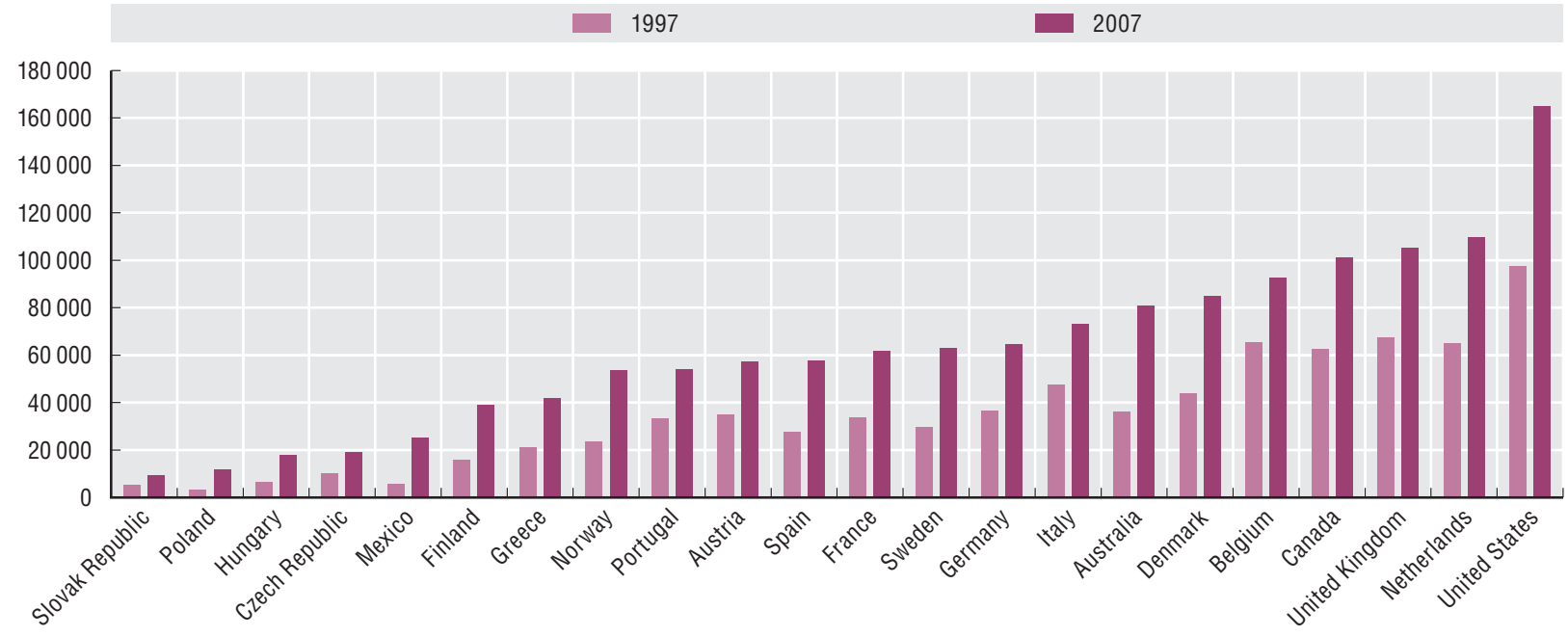

StatLink Aist http://dx.doi.org/10.1787/740503002734 



\section{Annex A: Reference Series}

Gross domestic product

Actual individual consumption

Population

Purchasing power parities

Exchanges rates 
Table A.1. Gross domestic product, 2000 constant PPPs

Billion US dollars

\begin{tabular}{|c|c|c|c|c|c|c|c|c|c|c|c|c|c|c|}
\hline & 1995 & 1996 & 1997 & 1998 & 1999 & 2000 & 2001 & 2002 & 2003 & 2004 & 2005 & 2006 & 2007 & 2008 \\
\hline Australia & 434 & 450 & 471 & 495 & 515 & 525 & 545 & 562 & 585 & 601 & 619 & 639 & 663 & $678 \mathrm{e}$ \\
\hline Austria & 199 & 203 & 207 & 215 & 222 & 230 & 231 & 235 & 237 & 243 & 249 & 258 & 267 & 272 \\
\hline Belgium & 247 & 250 & 259 & 263 & 272 & 282 & 284 & 289 & 292 & 300 & 306 & 315 & 324 & 327 \\
\hline Canada & 713 & 725 & 755 & 786 & 830 & 873 & 889 & 915 & 932 & 961 & 988 & 1019 & 1047 & $1051 \mathrm{e}$ \\
\hline Czech Republic & 143 & 149 & 148 & 146 & 148 & 154 & 158 & 161 & 166 & 174 & 185 & 197 & 210 & 215 \\
\hline Denmark & 133 & 137 & 142 & 145 & 148 & 154 & 155 & 155 & 156 & 160 & 164 & 169 & 172 & 170 \\
\hline Finland & 105 & 109 & 116 & 122 & 126 & 133 & 136 & 138 & 141 & 146 & 150 & 158 & 164 & 166 \\
\hline France & 1335 & 1350 & 1380 & 1428 & 1475 & 1533 & 1561 & 1577 & 1594 & 1634 & 1665 & 1702 & 1741 & 1749 \\
\hline Germany & 1929 & 1948 & 1983 & 2023 & 2064 & 2130 & 2157 & 2157 & 2152 & 2178 & 2194 & 2264 & 2320 & 2349 \\
\hline Greece & $169 \mathrm{e}$ & $173 \mathrm{e}$ & $180 \mathrm{e}$ & $186 \mathrm{e}$ & $192 \mathrm{e}$ & 201 & 209 & 216 & 229 & 240 & 245 & 256 & 268 & 273 \\
\hline Hungary & 102 & 103 & 107 & 113 & 118 & 124 & 129 & 134 & 140 & 147 & 152 & 158 & 160 & 161 \\
\hline Iceland & 6 & 7 & 7 & 7 & 8 & 8 & 8 & 8 & 9 & 9 & 10 & 10 & 11 & 11 \\
\hline Ireland & 69 & 74 & 83 & 90 & 99 & 109 & 115 & 123 & 128 & 134 & 142 & 150 & 159 & 154 \\
\hline Italy & 1325 & 1339 & 1364 & 1384 & 1404 & 1456 & 1482 & 1489 & 1489 & 1511 & 1521 & 1552 & 1577 & 1560 \\
\hline Japan & 3092 & 3177 & 3227 & 3160 & 3156 & 3246 & 3252 & 3261 & 3307 & 3398 & 3463 & 3534 & 3619 & $3593 \mathrm{e}$ \\
\hline Korea & $650 \mathrm{e}$ & $696 \mathrm{e}$ & $728 \mathrm{e}$ & $678 \mathrm{e}$ & $743 \mathrm{e}$ & 806 & 838 & 897 & 923 & 965 & 1003 & 1055 & 1109 & 1134 \\
\hline Luxembourg & 17 & 18 & 19 & 20 & 22 & 23 & 24 & 25 & 25 & 26 & 28 & 29 & 31 & 31 \\
\hline Mexico & $756 \mathrm{e}$ & $795 \mathrm{e}$ & $849 \mathrm{e}$ & $891 \mathrm{e}$ & $925 \mathrm{e}$ & $986 \mathrm{e}$ & $986 \mathrm{e}$ & $993 \mathrm{e}$ & 1007 & 1047 & 1082 & 1136 & 1175 & $1191 \mathrm{e}$ \\
\hline Netherlands & 384 & 397 & 414 & 430 & 450 & 468 & 477 & 477 & 479 & 489 & 499 & 516 & 535 & 546 \\
\hline New Zealand & 70 & 73 & 74 & 74 & 78 & 80 & 83 & 87 & 91 & 94 & 97 & 99 & 102 & $101 \mathrm{e}$ \\
\hline Norway & 135 & 142 & 150 & 154 & 157 & 162 & 165 & 168 & 169 & 176 & 181 & 185 & 191 & 195 \\
\hline Poland & 310 & 330 & 353 & 371 & 387 & 404 & 409 & 415 & 431 & 454 & 470 & 499 & 533 & 560 \\
\hline Portugal & 143 & 148 & 154 & 162 & 168 & 175 & 178 & 179 & 178 & 181 & 182 & 185 & 188 & 188 \\
\hline Slovak Republic & 50 & 54 & 56 & 58 & 58 & 59 & 61 & 64 & 67 & 71 & 75 & 82 & 90 & 96 \\
\hline Spain & 701 & 718 & 746 & 779 & 816 & 857 & 889 & 913 & 941 & 972 & 1007 & 1047 & 1085 & 1094 \\
\hline Sweden & 209 & 212 & 217 & 225 & 236 & 246 & 249 & 255 & 259 & 270 & 279 & 291 & 298 & 298 \\
\hline Switzerland & 206 & 207 & 211 & 217 & 220 & 228 & 230 & 231 & 231 & 237 & 243 & 252 & 261 & 265 \\
\hline Turkey & $481 \mathrm{e}$ & $515 \mathrm{e}$ & $553 \mathrm{e}$ & 570 & 551 & 589 & 555 & 589 & 620 & 678 & 735 & 786 & 823 & 830 \\
\hline United Kingdom & 1295 & 1332 & 1377 & 1426 & 1476 & 1533 & 1571 & 1604 & 1649 & 1695 & 1730 & 1779 & 1833 & 1846 \\
\hline United States & 8002 & 8305 & 8679 & 9061 & 9502 & 9899 & 10007 & 10190 & 10445 & 10819 & 11150 & 11449 & 11693 & 11742 \\
\hline Euro area & 6735 & 6840 & 7016 & 7214 & 7424 & 7711 & 7857 & 7930 & 7995 & 8167 & 8305 & 8554 & 8789 & 8848 \\
\hline OECD-Total & $23413 \mathrm{e}$ & $24135 \mathrm{e}$ & $25006 \mathrm{e}$ & $25679 \mathrm{e}$ & $26567 \mathrm{e}$ & $27671 \mathrm{e}$ & $28032 \mathrm{e}$ & $28508 \mathrm{e}$ & 29070 & 30003 & 30807 & 31762 & 32636 & $32836 \mathrm{e}$ \\
\hline
\end{tabular}

StatLink AाIs http://dx.doi.org/10.1787/741578381031 
Table A.2. Gross domestic product per capita, current PPPs

US dollars

\begin{tabular}{|c|c|c|c|c|c|c|c|c|c|c|c|c|c|c|}
\hline & 1995 & 1996 & 1997 & 1998 & 1999 & 2000 & 2001 & 2002 & 2003 & 2004 & 2005 & 2006 & 2007 & 2008 \\
\hline Australia & 21573 & 22385 & 23488 & 24662 & 26128 & 27233 & 28281 & 29610 & 31139 & 32429 & 33963 & 35666 & 37565 & 38591 e \\
\hline Austria & 23549 & 24361 & 24927 & 26083 & 27011 & 28736 & 28806 & 30231 & 31094 & 32610 & 33409 & 35163 & 37176 & 37867 \\
\hline Belgium & 22509 & 22839 & 23839 & 24342 & 25299 & 27540 & 28435 & 29946 & 30146 & 31035 & 32063 & 33608 & 35382 & 35222 \\
\hline Canada & 22771 & 23334 & 24481 & 25554 & 27135 & 28447 & 29334 & 29893 & 31242 & 32811 & 35002 & 36867 & 38500 & $39045 \mathrm{e}$ \\
\hline Czech Republic & 12839 & 13668 & 13837 & 13966 & 14312 & 14975 & 16178 & 16872 & 18000 & 19311 & 20366 & 22012 & 24063 & 24595 \\
\hline Denmark & 23038 & 24096 & 25274 & 26146 & 26926 & 28789 & 29445 & 30756 & 30441 & 32314 & 33196 & 34871 & 35961 & 36362 \\
\hline Finland & 18810 & 19317 & 20998 & 22656 & 23686 & 25638 & 26637 & 27560 & 27676 & 29867 & 30644 & 32580 & 34700 & 35337 \\
\hline France & 20262 & 20845 & 21760 & 22800 & 23628 & 25243 & 26651 & 27777 & 27412 & 28284 & 29692 & 30946 & 32633 & 32985 \\
\hline Germany & 22537 & 23098 & 23593 & 24256 & 25142 & 25919 & 26862 & 27587 & 28579 & 29912 & 31366 & 32886 & 34466 & 35652 \\
\hline Greece & 14708 & 15205 & 16052 & 16510 & 17032 & 18389 & 19934 & 21598 & 22712 & 24168 & 24641 & 26356 & 28206 & 28829 \\
\hline Hungary & 9049 & 9442 & 10079 & 10813 & 11260 & 12099 & 13563 & 14755 & 15412 & 16308 & 16952 & 18008 & 18746 & 19272 \\
\hline Iceland & 23266 & 24208 & 26110 & 27832 & 28632 & 28807 & 30451 & 31084 & 30781 & 33710 & 35027 & 35113 & 36311 & 36498 \\
\hline Ireland & 17943 & 19589 & 21759 & 24002 & 25909 & 28643 & 30518 & 33047 & 34531 & 36538 & 38675 & 41678 & 44826 & 41933 \\
\hline Italy & 21154 & 21842 & 22596 & 23732 & 24196 & 25565 & 27134 & 26804 & 27149 & 27426 & 28144 & 29463 & 30538 & 30873 \\
\hline Japan & 22546 & 23552 & 24264 & 23971 & 24245 & 25576 & 26160 & 26805 & 27488 & 29033 & 30312 & 31938 & 33603 & $34112 \mathrm{e}$ \\
\hline Korea & $13362 \mathrm{e}$ & $14431 \mathrm{e}$ & $15211 \mathrm{e}$ & $14223 \mathrm{e}$ & $15685 \mathrm{e}$ & 17137 & 18169 & 19656 & 20145 & 21671 & 22783 & 24736 & 26833 & 27939 \\
\hline Luxembourg & 38919 & 40169 & 40736 & 43094 & 48857 & 53315 & 53921 & 57546 & 60737 & 65004 & 68313 & 76266 & 82407 & 83353 \\
\hline Mexico & $7547 \mathrm{e}$ & $7962 \mathrm{e}$ & $8518 \mathrm{e}$ & $8920 \mathrm{e}$ & $9261 \mathrm{e}$ & $10034 \mathrm{e}$ & $10137 \mathrm{e}$ & $10398 \mathrm{e}$ & 10879 & 11527 & 12462 & 13381 & 14049 & $14427 \mathrm{e}$ \\
\hline Netherlands & 21595 & 22683 & 24110 & 25486 & 26933 & 29371 & 30796 & 31943 & 31716 & 33221 & 35111 & 37150 & 39333 & 41453 \\
\hline New Zealand & 17166 & 17647 & 18328 & 18604 & 19819 & 20679 & 21517 & 22224 & 22860 & 24002 & 24626 & 25791 & 26911 & $26651 \mathrm{e}$ \\
\hline Norway & 23644 & 26089 & 27978 & 27421 & 29800 & 36084 & 37101 & 37052 & 38316 & 42274 & 47319 & 52118 & 53477 & 58390 \\
\hline Poland & 7498 & 8135 & 8876 & 9470 & 9996 & 10555 & 10953 & 11563 & 11990 & 13020 & 13786 & 14842 & 16111 & 17675 \\
\hline Portugal & 13097 & 13644 & 14446 & 15176 & 16113 & 17067 & 17804 & 18447 & 18799 & 19178 & 20656 & 21656 & 22806 & 23162 \\
\hline Slovak Republic & 8325 & 9041 & 9745 & 10323 & 10403 & 10962 & 12058 & 12970 & 13603 & 14681 & 16175 & 18020 & 20079 & 22081 \\
\hline Spain & 16021 & 16735 & 17706 & 18896 & 19824 & 21295 & 22597 & 24067 & 24759 & 25968 & 27377 & 29580 & 31650 & 31744 \\
\hline Sweden & 21911 & 22673 & 23432 & 24269 & 25801 & 27726 & 27971 & 29004 & 30076 & 32078 & 32298 & 34456 & 36632 & 37309 \\
\hline Switzerland & 26675 & 27369 & 28503 & 29509 & 30028 & 31581 & 32111 & 33391 & 33281 & 34550 & 35478 & 38340 & 41215 & 43114 \\
\hline Turkey & $6922 \mathrm{e}$ & $7441 \mathrm{e}$ & $8181 \mathrm{e}$ & 8439 & 8046 & 8724 & 8178 & 8217 & 8316 & 9595 & 10841 & 12074 & $12798 \mathrm{e}$ & $13342 \mathrm{e}$ \\
\hline United Kingdom & 19755 & 20977 & 22435 & 23311 & 24249 & 26041 & 27585 & 28888 & 29862 & 31741 & 32684 & 34137 & 35543 & 35855 \\
\hline United States & 27606 & 28860 & 30330 & 31653 & 33298 & 35051 & 35871 & 36765 & 38143 & 40267 & 42494 & 44630 & 46434 & 47186 \\
\hline Euro area & 19991 & 20636 & 21453 & 22416 & 23246 & 24610 & 25830 & 26669 & 27114 & 28143 & 29403 & 30977 & 32638 & 33274 \\
\hline OECD-Total & $19669 \mathrm{e}$ & $20532 \mathrm{e}$ & $21526 \mathrm{e}$ & $22235 \mathrm{e}$ & $23149 \mathrm{e}$ & $24488 \mathrm{e}$ & $25284 \mathrm{e}$ & $26061 \mathrm{e}$ & 26827 & 28278 & 29753 & 31428 & $32984 \mathrm{e}$ & $33659 \mathrm{e}$ \\
\hline
\end{tabular}

StatLink Aाs http://dx.doi.org/10.1787/741627002062 
Table A.3. Gross domestic product per capita, 2000 constant PPPs

US dollars

\begin{tabular}{|c|c|c|c|c|c|c|c|c|c|c|c|c|c|c|}
\hline & 1995 & 1996 & 1997 & 1998 & 1999 & 2000 & 2001 & 2002 & 2003 & 2004 & 2005 & 2006 & 2007 & 2008 \\
\hline Australia & 23829 & 24457 & 25298 & 26323 & 27054 & 27233 & 27896 & 28460 & 29252 & 29714 & 30171 & 30711 & 31343 & $31522 \mathrm{e}$ \\
\hline Austria & 25002 & 25525 & 26038 & 26945 & 27791 & 28736 & 28775 & 29105 & 29208 & 29763 & 30288 & 31175 & 32152 & 32671 \\
\hline Belgium & 24359 & 24607 & 25408 & 25777 & 26609 & 27540 & 27664 & 27949 & 28109 & 28820 & 29193 & 29868 & 30463 & 30790 \\
\hline Canada & 24333 & 24469 & 25250 & 26067 & 27286 & 28447 & 28644 & 29152 & 29416 & 30031 & 30591 & 31217 & 31746 & $31510 \mathrm{e}$ \\
\hline Czech Republic & 13833 & 14412 & 14323 & 14226 & 14433 & 14975 & 15415 & 15744 & 16310 & 17032 & 18060 & 19228 & 20296 & 20583 \\
\hline Denmark & 25525 & 26089 & 26806 & 27292 & 27896 & 28789 & 28889 & 28921 & 28957 & 29550 & 30183 & 31090 & 31468 & 30909 \\
\hline Finland & 20534 & 21224 & 22474 & 23588 & 24456 & 25638 & 26271 & 26618 & 27037 & 27960 & 28636 & 29925 & 31051 & 31230 \\
\hline France & 22463 & 22634 & 23061 & 23783 & 24458 & 25243 & 25527 & 25604 & 25702 & 26146 & 26444 & 26849 & 27312 & 27274 \\
\hline Germany & 23618 & 23785 & 24168 & 24666 & 25144 & 25919 & 26192 & 26147 & 26078 & 26399 & 26610 & 27485 & 28197 & 28602 \\
\hline Greece & $15934 \mathrm{e}$ & $16196 \mathrm{e}$ & $16680 \mathrm{e}$ & $17149 \mathrm{e}$ & $17657 \mathrm{e}$ & 18389 & 19104 & 19693 & 20796 & 21682 & 22084 & 22990 & 23923 & 24309 \\
\hline Hungary & 9870 & 9988 & 10439 & 11004 & 11502 & 12099 & 12627 & 13222 & 13826 & 14530 & 15072 & 15695 & 15871 & 16002 \\
\hline Iceland & 23866 & 24864 & 25895 & 27241 & 28009 & 28807 & 29527 & 29311 & 29839 & 31774 & 33758 & 34285 & 35355 & 34593 \\
\hline Ireland & 19098 & 20501 & 22642 & 24219 & 26510 & 28643 & 29826 & 31212 & 32052 & 32962 & 34243 & 35189 & 36421 & 34632 \\
\hline Italy & 23307 & 23556 & 23984 & 24313 & 24665 & 25565 & 26013 & 26049 & 25843 & 25981 & 25959 & 26337 & 26553 & 26052 \\
\hline Japan & 24622 & 25240 & 25576 & 24990 & 24916 & 25576 & 25545 & 25578 & 25897 & 26588 & 27107 & 27659 & 28321 & $28140 \mathrm{e}$ \\
\hline Korea & $14421 \mathrm{e}$ & $15283 \mathrm{e}$ & $15845 \mathrm{e}$ & $14653 \mathrm{e}$ & $15929 \mathrm{e}$ & 17137 & 17687 & 18846 & 19278 & 20093 & 20845 & 21852 & 22893 & 23329 \\
\hline Luxembourg & 42378 & 42411 & 44353 & 46633 & 49857 & 53315 & 54285 & 55919 & 56105 & 57742 & 59949 & 62298 & 65309 & 64180 \\
\hline Mexico & $8296 \mathrm{e}$ & $8590 \mathrm{e}$ & $9038 \mathrm{e}$ & $9361 \mathrm{e}$ & $9580 \mathrm{e}$ & $10034 \mathrm{e}$ & $9899 \mathrm{e}$ & $9857 \mathrm{e}$ & 9885 & 10182 & 10419 & 10847 & 11121 & $11177 \mathrm{e}$ \\
\hline Netherlands & 24808 & 25544 & 26498 & 27370 & 28460 & 29371 & 29711 & 29542 & 29503 & 30064 & 30603 & 31595 & 32662 & 33189 \\
\hline New Zealand & 18881 & 19267 & 19415 & 19403 & 20313 & 20679 & 21106 & 21718 & 22286 & 22857 & 23258 & 23421 & 23912 & $23427 \mathrm{e}$ \\
\hline Norway & 31034 & 32446 & 34009 & 34709 & 35174 & 36084 & 36623 & 36960 & 37122 & 38338 & 39124 & 39681 & 40534 & 40859 \\
\hline Poland & 8105 & 8608 & 9217 & 9678 & 10120 & 10555 & 10683 & 10843 & 11273 & 11880 & 12316 & 13093 & 13987 & 14687 \\
\hline Portugal & 14244 & 14719 & 15284 & 15966 & 16509 & 17067 & 17297 & 17302 & 17043 & 17201 & 17280 & 17458 & 17745 & 17715 \\
\hline Slovak Republic & 9343 & 9972 & 10390 & 10831 & 10825 & 10962 & 11379 & 11922 & 12485 & 13121 & 13968 & 15144 & 16705 & 17742 \\
\hline Spain & 17802 & 18190 & 18844 & 19617 & 20443 & 21295 & 21824 & 22093 & 22403 & 22762 & 23201 & 23766 & 24171 & 23994 \\
\hline Sweden & 23647 & 23954 & 24530 & 25451 & 26599 & 27726 & 27943 & 28524 & 28962 & 30037 & 30904 & 32036 & 32615 & 32314 \\
\hline Switzerland & 29062 & 29144 & 29715 & 30420 & 30669 & 31581 & 31611 & 31502 & 31176 & 31755 & 32389 & 33314 & 34239 & 34435 \\
\hline Turkey & $7801 \mathrm{e}$ & $8207 \mathrm{e}$ & $8856 \mathrm{e}$ & 8989 & 8567 & 8724 & 8089 & 8463 & 8772 & 9449 & 10204 & 10771 & $11136 \mathrm{e}$ & $11102 \mathrm{e}$ \\
\hline United Kingdom & 22321 & 22908 & 23605 & 24389 & 25146 & 26041 & 26580 & 27041 & 27694 & 28320 & 28715 & 29359 & 30054 & 30082 \\
\hline United States & 30016 & 30791 & 31796 & 32811 & 34018 & 35051 & 35076 & 35375 & 35927 & 36882 & 37666 & 38313 & 38753 & 38559 \\
\hline Euro area & 21796 & 22076 & 22587 & 23176 & 23785 & 24610 & 24961 & 25054 & 25102 & 25477 & 25752 & 26381 & 26950 & 26988 \\
\hline OECD-Total & $21480 \mathrm{e}$ & $21983 \mathrm{e}$ & $22641 \mathrm{e}$ & $23094 \mathrm{e}$ & $23733 \mathrm{e}$ & $24488 \mathrm{e}$ & $24624 \mathrm{e}$ & 24865 e & 25176 & 25806 & 26336 & 26976 & 27529 & $27514 \mathrm{e}$ \\
\hline
\end{tabular}

StatLink AाIst http://dx.doi.org/10.1787/741631033635 
Table A.4. Actual individual consumption, current PPPs

\begin{tabular}{|c|c|c|c|c|c|c|c|c|c|c|c|c|c|c|}
\hline & 1995 & 1996 & 1997 & 1998 & 1999 & 2000 & 2001 & 2002 & 2003 & 2004 & 2005 & 2006 & 2007 & 2008 \\
\hline Australia & 269 & 282 & 300 & 321 & 340 & 368 & 387 & 416 & 432 & 465 & 474 & 505 & 543 & $577 \mathrm{e}$ \\
\hline Austria & 124 & 130 & 132 & 137 & 142 & 157 & 158 & 169 & 173 & 183 & 181 & 194 & 203 & 213 \\
\hline Belgium & 152 & 157 & 162 & 165 & 170 & 195 & 202 & 218 & 215 & 227 & 224 & 239 & 252 & 264 \\
\hline Canada & 466 & 485 & 509 & 528 & 556 & 591 & 619 & 648 & 676 & 716 & 758 & 812 & 871 & $929 \mathrm{e}$ \\
\hline Czech Republic & 85 & 94 & 97 & 97 & 101 & 108 & 116 & 121 & 127 & 135 & 125 & 145 & 156 & 167 \\
\hline Denmark & 81 & 85 & 89 & 93 & 95 & 101 & 102 & 112 & 108 & 115 & 120 & 125 & 131 & 137 \\
\hline Finland & 60 & 63 & 66 & 70 & 74 & 82 & 85 & 92 & 94 & 100 & 107 & 111 & 117 & 124 \\
\hline France & 869 & 903 & 932 & 974 & 1019 & 1141 & 1218 & 1323 & 1298 & 1360 & 1350 & 1465 & 1546 & 1619 \\
\hline Germany & 1298 & 1345 & 1368 & 1389 & 1458 & 1557 & 1618 & 1689 & 1736 & 1788 & 1813 & 1933 & 1974 & 2057 \\
\hline Greece & $126 \mathrm{e}$ & $132 \mathrm{e}$ & $139 \mathrm{e}$ & $141 \mathrm{e}$ & $145 \mathrm{e}$ & 159 & 175 & 199 & 198 & 210 & 216 & 235 & 250 & 264 \\
\hline Hungary & 72 & 71 & 74 & 78 & 83 & 90 & 98 & 112 & 117 & 122 & 116 & 130 & 132 & 136 \\
\hline Iceland & 4 & 4 & 5 & 5 & 6 & 6 & 6 & 6 & 7 & 7 & 8 & 8 & 9 & 10 \\
\hline Ireland & 40 & 43 & 46 & 50 & 54 & 63 & 67 & 74 & 78 & 83 & 90 & 97 & 106 & 110 \\
\hline Italy & 791 & 811 & 852 & 904 & 936 & 1024 & 1094 & 1088 & 1106 & 1131 & 1169 & 1221 & 1271 & 1309 \\
\hline Japan & 1725 & 1808 & 1853 & 1857 & 1917 & 2058 & 2141 & 2270 & 2357 & 2465 & 2607 & 2724 & 2829 & $2946 \mathrm{e}$ \\
\hline Korea & $375 \mathrm{e}$ & $408 \mathrm{e}$ & $429 \mathrm{e}$ & $382 \mathrm{e}$ & $430 \mathrm{e}$ & 480 & 517 & 577 & 582 & 600 & 638 & 687 & 737 & 773 \\
\hline Luxembourg & 8 & 9 & 9 & 10 & 10 & 12 & 12 & 14 & 13 & 14 & 14 & 14 & 15 & 16 \\
\hline Mexico & $517 \mathrm{e}$ & $538 \mathrm{e}$ & $580 \mathrm{e}$ & $615 \mathrm{e}$ & $653 \mathrm{e}$ & $738 \mathrm{e}$ & $768 \mathrm{e}$ & $810 \mathrm{e}$ & 834 & 901 & 969 & 1047 & 1120 & $1178 \mathrm{e}$ \\
\hline Netherlands & 212 & 225 & 238 & 255 & 276 & 313 & 328 & 358 & 348 & 362 & 356 & 393 & 413 & 434 \\
\hline New Zealand & 45 & 48 & 51 & 53 & 55 & 58 & 61 & 64 & 67 & 72 & 74 & 79 & 84 & $86 \mathrm{e}$ \\
\hline Norway & 64 & 70 & 73 & 76 & 79 & 87 & 91 & 99 & 103 & 111 & 121 & 122 & 131 & 138 \\
\hline Poland & 218 & 240 & 259 & 273 & 293 & 320 & 333 & 366 & 369 & 393 & 386 & 434 & 469 & 516 \\
\hline Portugal & 96 & 101 & 106 & 110 & 119 & 132 & 137 & 146 & 148 & 156 & 169 & 177 & 185 & 194 \\
\hline Slovak Republic & 28 & 34 & 38 & 40 & 40 & 43 & 48 & 53 & 53 & 56 & 56 & 67 & 74 & 81 \\
\hline Spain & 437 & 456 & 483 & 516 & 548 & 620 & 666 & 739 & 747 & 798 & 811 & 901 & 966 & 1001 \\
\hline Sweden & 127 & 132 & 135 & 141 & 152 & 168 & 171 & 185 & 189 & 197 & 198 & 208 & 219 & 228 \\
\hline Switzerland & 120 & 125 & 131 & 134 & 137 & 146 & 153 & 165 & 164 & 171 & 177 & 180 & 191 & $201 \mathrm{e}$ \\
\hline Turkey & $302 \mathrm{e}$ & $334 \mathrm{e}$ & $368 \mathrm{e}$ & $375 \mathrm{e}$ & $383 \mathrm{e}$ & $455 \mathrm{e}$ & $441 \mathrm{e}$ & $469 \mathrm{e}$ & $479 \mathrm{e}$ & $543 \mathrm{e}$ & $593 \mathrm{e}$ & $650 \mathrm{e}$ & $688 \mathrm{e}$ & $713 \mathrm{e}$ \\
\hline United Kingdom & 851 & 917 & 974 & 1013 & 1076 & 1211 & 1294 & 1405 & 1433 & 1537 & 1526 & 1655 & 1745 & 1835 \\
\hline United States & $5440 \mathrm{e}$ & $5745 \mathrm{e}$ & $6058 \mathrm{e}$ & $6433 \mathrm{e}$ & $6891 \mathrm{e}$ & $7419 \mathrm{e}$ & $7770 \mathrm{e}$ & $8099 \mathrm{e}$ & $8513 \mathrm{e}$ & $9030 \mathrm{e}$ & $9608 \mathrm{e}$ & $10164 \mathrm{e}$ & $10715 \mathrm{e}$ & $11091 \mathrm{e}$ \\
\hline Euro area & $4295 \mathrm{e}$ & $4465 \mathrm{e}$ & $4619 \mathrm{e}$ & $4810 \mathrm{e}$ & $5015 \mathrm{e}$ & $5335 \mathrm{e}$ & $5634 \mathrm{e}$ & $5850 \mathrm{e}$ & $6018 \mathrm{e}$ & $6262 \mathrm{e}$ & $6599 \mathrm{e}$ & $6938 \mathrm{e}$ & $7264 \mathrm{e}$ & $7505 \mathrm{e}$ \\
\hline OECD-Total & $15003 \mathrm{e}$ & $15797 \mathrm{e}$ & $16555 \mathrm{e}$ & $17234 \mathrm{e}$ & $18238 \mathrm{e}$ & $19900 \mathrm{e}$ & $20876 \mathrm{e}$ & $22087 \mathrm{e}$ & $22766 \mathrm{e}$ & $24046 \mathrm{e}$ & $25055 \mathrm{e}$ & $26721 \mathrm{e}$ & $28141 \mathrm{e}$ & $29348 \mathrm{e}$ \\
\hline
\end{tabular}

StatLink काIS $h t$ ttp://dx.doi.org/10.1787/741645352462 
Table A.5. Actual individual consumption, 2000 constant PPPs

Billion US dollars

\begin{tabular}{|c|c|c|c|c|c|c|c|c|c|c|c|c|c|c|}
\hline & 1995 & 1996 & 1997 & 1998 & 1999 & 2000 & 2001 & 2002 & 2003 & 2004 & 2005 & 2006 & 2007 & 2008 \\
\hline Australia & 301 & 309 & 323 & 343 & 357 & 368 & 378 & 393 & 414 & 433 & 444 & 459 & 477 & $489 \mathrm{e}$ \\
\hline Austria & 141 & 144 & 146 & 150 & 153 & 157 & 158 & 161 & 162 & 166 & 169 & 171 & 173 & 175 \\
\hline Belgium & 175 & 178 & 180 & 185 & 189 & 195 & 198 & 200 & 202 & 206 & 208 & 211 & 216 & $218 \mathrm{e}$ \\
\hline Canada & 509 & 519 & 536 & 550 & 569 & 591 & 606 & 626 & 644 & 665 & 687 & 716 & 747 & $770 \mathrm{e}$ \\
\hline Czech Republic & 97 & 104 & 106 & 104 & 107 & 108 & 111 & 114 & 121 & 124 & 127 & 132 & 138 & 142 \\
\hline Denmark & 93 & 95 & 98 & 100 & 101 & 101 & 102 & 104 & 105 & 109 & 113 & 117 & 120 & 121 \\
\hline Finland & 70 & 73 & 75 & 78 & 80 & 82 & 84 & 86 & 89 & 92 & 95 & 98 & 100 & 102 \\
\hline France & 1018 & 1033 & 1038 & 1072 & 1104 & 1141 & 1168 & 1197 & 1223 & 1253 & 1283 & 1310 & 1340 & 1356 \\
\hline Germany & 1421 & 1444 & 1459 & 1483 & 1522 & 1557 & 1584 & 1578 & 1583 & 1581 & 1592 & 1613 & 1614 & 1624 \\
\hline Greece & $141 \mathrm{e}$ & $144 \mathrm{e}$ & $148 \mathrm{e}$ & $152 \mathrm{e}$ & $156 \mathrm{e}$ & 159 & 166 & 174 & 181 & 187 & 197 & 207 & 215 & 220 \\
\hline Hungary & 81 & 79 & 80 & 83 & 87 & 90 & 96 & 105 & 114 & 117 & 121 & 124 & 122 & 121 \\
\hline Iceland & 4 & 5 & 5 & 5 & 6 & 6 & 6 & 6 & 6 & 7 & 7 & $8 \mathrm{e}$ & $8 \mathrm{e}$ & $8 \mathrm{e}$ \\
\hline Ireland & 43 & 46 & 49 & 52 & 57 & 63 & 67 & 70 & 72 & 75 & 79 & 84 & 89 & 88 \\
\hline Italy & $912 \mathrm{e}$ & $924 \mathrm{e}$ & $950 \mathrm{e}$ & $976 \mathrm{e}$ & 1000 & 1024 & 1037 & 1043 & 1055 & 1067 & 1081 & 1094 & 1106 & 1100 \\
\hline Japan & 1949 & 2000 & 2015 & 2000 & 2029 & 2058 & 2096 & 2123 & 2135 & 2171 & 2204 & 2236 & 2256 & $2268 \mathrm{e}$ \\
\hline Korea & $415 \mathrm{e}$ & $441 \mathrm{e}$ & $456 \mathrm{e}$ & $402 \mathrm{e}$ & $445 \mathrm{e}$ & 480 & 510 & 553 & 554 & 558 & 584 & 614 & 645 & 653 \\
\hline Luxembourg & 9 & 10 & 10 & 11 & 11 & 12 & 12 & 13 & 12 & 13 & 13 & 14 & 14 & 15 \\
\hline Mexico & $581 \mathrm{e}$ & $591 \mathrm{e}$ & $627 \mathrm{e}$ & $658 \mathrm{e}$ & $687 \mathrm{e}$ & $738 \mathrm{e}$ & $752 e$ & $762 \mathrm{e}$ & $771 \mathrm{e}$ & $810 \mathrm{e}$ & $848 \mathrm{e}$ & $894 \mathrm{e}$ & $927 \mathrm{e}$ & $941 \mathrm{e}$ \\
\hline Netherlands & 258 & 266 & 276 & 289 & 302 & 313 & 320 & 324 & 326 & 329 & 332 & 342 & 350 & 355 \\
\hline New Zealand & $50 \mathrm{e}$ & $52 \mathrm{e}$ & $53 \mathrm{e}$ & $55 \mathrm{e}$ & $57 \mathrm{e}$ & $58 \mathrm{e}$ & $59 \mathrm{e}$ & $62 \mathrm{e}$ & $66 \mathrm{e}$ & $69 \mathrm{e}$ & $72 \mathrm{e}$ & $74 \mathrm{e}$ & $76 \mathrm{e}$ & $76 \mathrm{e}$ \\
\hline Norway & 72 & 76 & 79 & 81 & 84 & 87 & 90 & 93 & 95 & 100 & 104 & 108 & 114 & 117 \\
\hline Poland & 247 & 266 & 283 & 295 & 311 & 320 & 328 & 337 & 345 & 360 & 368 & 387 & 406 & 431 \\
\hline Portugal & $108 \mathrm{e}$ & $113 e$ & $116 \mathrm{e}$ & $121 \mathrm{e}$ & $128 \mathrm{e}$ & $132 \mathrm{e}$ & $134 \mathrm{e}$ & $136 \mathrm{e}$ & $136 \mathrm{e}$ & $139 e$ & $142 \mathrm{e}$ & $144 \mathrm{e}$ & $145 \mathrm{e}$ & $148 \mathrm{e}$ \\
\hline Slovak Republic & 32 & 38 & 42 & 44 & 43 & 43 & 45 & 48 & 48 & 49 & 53 & 56 & $61 \mathrm{e}$ & $64 \mathrm{e}$ \\
\hline Spain & $509 \mathrm{e}$ & $521 \mathrm{e}$ & $537 \mathrm{e}$ & $562 \mathrm{e}$ & $591 \mathrm{e}$ & 620 & $642 \mathrm{e}$ & $662 \mathrm{e}$ & $683 \mathrm{e}$ & $714 \mathrm{e}$ & $744 \mathrm{e}$ & $771 \mathrm{e}$ & $799 \mathrm{e}$ & $800 \mathrm{e}$ \\
\hline Sweden & 148 & 150 & 152 & 158 & 163 & 168 & 170 & 175 & 177 & 180 & 185 & 189 & 193 & 194 \\
\hline Switzerland & 134 & 135 & 138 & 140 & 143 & 146 & 150 & 151 & 153 & 155 & 157 & 160 & 163 & $166 \mathrm{e}$ \\
\hline Turkey & $362 \mathrm{e}$ & $392 \mathrm{e}$ & $424 \mathrm{e}$ & $429 \mathrm{e}$ & $430 \mathrm{e}$ & $455 \mathrm{e}$ & $426 \mathrm{e}$ & $447 \mathrm{e}$ & $489 \mathrm{e}$ & $541 \mathrm{e}$ & $582 \mathrm{e}$ & $611 \mathrm{e}$ & $644 \mathrm{e}$ & $645 \mathrm{e}$ \\
\hline United Kingdom & 996 & 1032 & 1067 & 1108 & 1161 & 1211 & 1248 & 1292 & 1331 & 1370 & 1396 & 1423 & 1465 & 1488 \\
\hline United States & $6003 \mathrm{e}$ & $6199 \mathrm{e}$ & $6414 \mathrm{e}$ & $6741 \mathrm{e}$ & $7083 \mathrm{e}$ & $7419 \mathrm{e}$ & $7611 \mathrm{e}$ & $7805 \mathrm{e}$ & $8001 \mathrm{e}$ & 8245 e & $8479 \mathrm{e}$ & $8699 \mathrm{e}$ & $8905 \mathrm{e}$ & $8899 \mathrm{e}$ \\
\hline Euro area & $4747 \mathrm{e}$ & $4827 \mathrm{e}$ & $4904 \mathrm{e}$ & $5034 \mathrm{e}$ & $5184 \mathrm{e}$ & $5335 \mathrm{e}$ & $5444 \mathrm{e}$ & $5516 \mathrm{e}$ & $5590 \mathrm{e}$ & $5679 e$ & $5779 \mathrm{e}$ & $5898 \mathrm{e}$ & $6001 \mathrm{e}$ & $6051 \mathrm{e}$ \\
\hline OECD-Total & $16875 \mathrm{e}$ & 17373 e & 17874 e & $18423 \mathrm{e}$ & $19153 \mathrm{e}$ & $19900 \mathrm{e}$ & $20355 \mathrm{e}$ & $20838 \mathrm{e}$ & $21293 \mathrm{e}$ & $21879 \mathrm{e}$ & $22456 \mathrm{e}$ & $23052 \mathrm{e}$ & $23611 \mathrm{e}$ & $23772 \mathrm{e}$ \\
\hline
\end{tabular}

StatLink Aाs $\mathrm{Attp}: / / d x$. doi.org/10.1787/741650583872 
Table A.6. Population

Thousands

\begin{tabular}{|c|c|c|c|c|c|c|c|c|c|c|c|c|c|}
\hline & 1996 & 1997 & 1998 & 1999 & 2000 & 2001 & 2002 & 2003 & 2004 & 2005 & 2006 & 2007 & 2008 \\
\hline Australia & 18417 & 18606 & 18812 & 19036 & 19270 & 19527 & 19752 & 19986 & 20226 & 20518 & 20822 & 21153 & $21514 \mathrm{e}$ \\
\hline Austria & 7959 & 7968 & 7977 & 7992 & 8012 & 8042 & 8082 & 8118 & 8169 & 8225 & 8268 & 8301 & 8337 \\
\hline Belgium & 10155 & 10180 & 10203 & 10222 & 10246 & 10281 & 10330 & 10373 & 10417 & 10474 & 10543 & 10622 & 10622 \\
\hline Canada & 29611 & 29907 & 30157 & 30404 & 30689 & 31021 & 31373 & 31676 & 31995 & 32312 & 32649 & 32976 & $33361 \mathrm{e}$ \\
\hline Czech Republic & 10315 & 10304 & 10295 & 10283 & 10273 & 10224 & 10201 & 10202 & 10207 & 10234 & 10267 & 10323 & 10430 \\
\hline Denmark & 5262 & 5285 & 5303 & 5321 & 5338 & 5357 & 5376 & 5390 & 5403 & 5419 & 5437 & 5460 & 5492 \\
\hline Finland & 5125 & 5140 & 5153 & 5165 & 5176 & 5188 & 5201 & 5213 & 5227 & 5245 & 5266 & 5289 & 5313 \\
\hline France & 59624 & 59831 & 60047 & 60315 & 60725 & 61163 & 61605 & 62038 & 62491 & 62958 & 63382 & 63758 & 64120 \\
\hline Germany & 81896 & 82052 & 82029 & 82087 & 82188 & 82340 & 82482 & 82520 & 82501 & 82464 & 82366 & 82263 & 82120 \\
\hline Greece & 10709 & 10777 & 10835 & 10883 & 10917 & 10950 & 10988 & 11024 & 11062 & 11104 & 11149 & 11193 & 11237 \\
\hline Hungary & 10311 & 10290 & 10267 & 10238 & 10211 & 10188 & 10159 & 10130 & 10107 & 10087 & 10071 & 10056 & 10038 \\
\hline Iceland & 269 & 271 & 274 & 277 & 281 & 285 & 288 & 289 & 293 & 296 & 304 & 311 & 319 \\
\hline Ireland & 3626 & 3661 & 3711 & 3751 & 3800 & 3859 & 3926 & 3991 & 4059 & 4149 & 4253 & 4357 & 4443 \\
\hline Italy & 56860 & 56890 & 56907 & 56916 & 56942 & 56977 & 57157 & 57605 & 58175 & 58607 & 58942 & 59375 & 59889 \\
\hline Japan & 125859 & 126157 & 126472 & 126667 & 126926 & 127316 & 127486 & 127694 & 127787 & 127768 & 127770 & 127771 & 127692 \\
\hline Korea & 45525 & 45954 & 46287 & 46617 & 47008 & 47357 & 47622 & 47859 & 48039 & 48138 & 48297 & 48456 & 48607 \\
\hline Luxembourg & 416 & 421 & 426 & 432 & 439 & 442 & 446 & 452 & 458 & 465 & 473 & 480 & 489 \\
\hline Mexico & 92544 & 93908 & 95233 & 96550 & 98258 & 99564 & 100762 & 101870 & 102866 & 103831 & 104748 & 105677 & $106568 \mathrm{e}$ \\
\hline Netherlands & 15526 & 15607 & 15703 & 15809 & 15922 & 16043 & 16147 & 16223 & 16276 & 16317 & 16341 & 16378 & 16440 \\
\hline New Zealand & 3775 & 3811 & 3833 & 3856 & 3877 & 3936 & 4013 & 4079 & 4127 & 4176 & 4223 & 4264 & $4305 \mathrm{e}$ \\
\hline Norway & 4381 & 4405 & 4432 & 4462 & 4491 & 4513 & 4539 & 4565 & 4591 & 4622 & 4661 & 4706 & 4768 \\
\hline Poland & 38289 & 38292 & 38283 & 38270 & 38256 & 38251 & 38232 & 38195 & 38180 & 38161 & 38132 & 38116 & 38116 \\
\hline Portugal & 10058 & 10091 & 10129 & 10172 & 10226 & 10293 & 10368 & 10441 & 10502 & 10549 & 10584 & 10608 & 10622 \\
\hline Slovak Republic & 5374 & 5383 & 5391 & 5396 & 5401 & 5380 & 5379 & 5379 & 5382 & 5387 & 5391 & 5397 & 5406 \\
\hline Spain & 39479 & 39583 & 39722 & 39927 & 40264 & 40721 & 41314 & 42005 & 42692 & 43398 & 44068 & 44874 & 45593 \\
\hline Sweden & 8841 & 8846 & 8851 & 8858 & 8872 & 8896 & 8925 & 8958 & 8994 & 9030 & 9081 & 9148 & 9219 \\
\hline Switzerland & 7105 & 7113 & 7132 & 7167 & 7209 & 7285 & 7343 & 7405 & 7454 & 7501 & 7558 & 7619 & 7710 \\
\hline Turkey & 62697 & 62480 & 63459 & 64345 & 67461 & 68618 & 69626 & 70712 & 71789 & 72065 & 72974 & $73876 \mathrm{e}$ & $74768 \mathrm{e}$ \\
\hline United Kingdom & 58164 & 58314 & 58475 & 58684 & 58886 & 59113 & 59323 & 59557 & 59846 & 60238 & 60587 & 60975 & 61350 \\
\hline United States & 269714 & 272958 & 276154 & 279328 & 282413 & 285294 & 288055 & 290729 & 293348 & 296036 & 298820 & 301737 & 304529 \\
\hline Euro area & 309838 & 310624 & 311279 & 312126 & 313330 & 314766 & 316528 & 318498 & 320556 & 322513 & 324228 & 326122 & 327864 \\
\hline OECD-Total & 1097887 & 1104487 & 1111950 & 1119430 & 1129975 & 1138425 & 1146499 & 1154677 & 1162665 & 1169775 & 1177427 & $1185518 \mathrm{e}$ & 1193417 e \\
\hline
\end{tabular}

StatLink Aाs 
Table A.7. Purchasing power parities for GDP

National currency per US dollar

\begin{tabular}{|c|c|c|c|c|c|c|c|c|c|c|c|c|c|c|}
\hline & 1995 & 1996 & 1997 & 1998 & 1999 & 2000 & 2001 & 2002 & 2003 & 2004 & 2005 & 2006 & 2007 & 2008 \\
\hline Australia & 1.32 & 1.32 & 1.32 & 1.31 & 1.30 & 1.31 & 1.33 & 1.34 & 1.35 & 1.37 & 1.39 & 1.41 & 1.42 & 1.48 \\
\hline Austria & 0.933 & 0.929 & 0.924 & 0.917 & 0.917 & 0.901 & 0.917 & 0.896 & 0.885 & 0.874 & 0.886 & 0.881 & 0.877 & 0.893 \\
\hline Belgium & 0.911 & 0.911 & 0.911 & 0.924 & 0.921 & 0.892 & 0.886 & 0.865 & 0.879 & 0.896 & 0.900 & 0.898 & 0.891 & 0.920 \\
\hline Canada & 1.21 & 1.21 & 1.21 & 1.19 & 1.19 & 1.23 & 1.22 & 1.23 & 1.23 & 1.23 & 1.21 & 1.21 & 1.21 & 1.23 \\
\hline Czech Republic & 11.1 & 11.9 & 12.7 & 13.9 & 14.1 & 14.2 & 14.2 & 14.3 & 14.0 & 14.3 & 14.3 & 14.3 & 14.2 & 14.4 \\
\hline Denmark & 8.46 & 8.44 & 8.43 & 8.39 & 8.47 & 8.42 & 8.47 & 8.30 & 8.54 & 8.40 & 8.59 & 8.59 & 8.60 & 8.68 \\
\hline Finland & 0.998 & 1.000 & 0.997 & 1.000 & 1.000 & 0.996 & 1.010 & 1.000 & 1.010 & 0.975 & 0.977 & 0.973 & 0.979 & 0.984 \\
\hline France & 0.992 & 0.987 & 0.974 & 0.967 & 0.960 & 0.940 & 0.918 & 0.905 & 0.938 & 0.939 & 0.923 & 0.921 & 0.911 & 0.922 \\
\hline Germany & 1.000 & 0.992 & 0.990 & 0.988 & 0.975 & 0.968 & 0.955 & 0.942 & 0.917 & 0.896 & 0.867 & 0.858 & 0.856 & 0.852 \\
\hline Greece & 0.573 & 0.604 & 0.629 & 0.662 & 0.681 & 0.679 & 0.671 & 0.660 & 0.689 & 0.695 & 0.714 & 0.716 & 0.717 & 0.738 \\
\hline Hungary & 61.6 & 73.1 & 85.0 & 94.1 & 101.0 & 108.0 & 111.0 & 115.0 & 121.0 & 126.0 & 129.0 & 131.0 & 135.0 & 137.0 \\
\hline Iceland & 73.0 & 74.9 & 74.4 & 77.2 & 79.7 & 84.4 & 88.9 & 91.3 & 94.5 & 94.2 & 99.1 & 109.0 & 115.0 & 126.0 \\
\hline Ireland & 0.822 & 0.827 & 0.853 & 0.882 & 0.930 & 0.963 & 0.993 & 1.000 & 1.010 & 1.010 & 1.010 & 0.997 & 0.972 & 0.976 \\
\hline Italy & 0.788 & 0.808 & 0.816 & 0.808 & 0.818 & 0.818 & 0.808 & 0.845 & 0.854 & 0.872 & 0.867 & 0.855 & 0.852 & 0.850 \\
\hline Japan & 174 & 170 & 168 & 167 & 162 & 155 & 149 & 144 & 140 & 134 & 130 & 124 & 120 & 117 \\
\hline Korea & 690 & 712 & 732 & 767 & 755 & 749 & 757 & 770 & 796 & 794 & 789 & 761 & 750 & 754 \\
\hline Luxembourg & 0.948 & 0.946 & 0.957 & 0.948 & 0.941 & 0.941 & 0.948 & 0.934 & 0.942 & 0.922 & 0.953 & 0.947 & 0.947 & 0.966 \\
\hline Mexico & 2.93 & 3.76 & 4.35 & 4.96 & 5.63 & 6.11 & 6.31 & 6.55 & 6.82 & 7.22 & 7.13 & 7.38 & 7.53 & 7.86 \\
\hline Netherlands & 0.914 & 0.908 & 0.910 & 0.906 & 0.907 & 0.894 & 0.906 & 0.902 & 0.927 & 0.908 & 0.896 & 0.890 & 0.883 & 0.874 \\
\hline New Zealand & 1.46 & 1.47 & 1.45 & 1.45 & 1.43 & 1.45 & 1.47 & 1.47 & 1.50 & 1.51 & 1.54 & 1.52 & 1.55 & 1.59 \\
\hline Norway & 9.16 & 9.04 & 9.08 & 9.38 & 9.33 & 9.14 & 9.18 & 9.11 & 9.11 & 8.98 & 8.90 & 8.89 & 9.05 & 9.15 \\
\hline Poland & 1.18 & 1.36 & 1.52 & 1.66 & 1.74 & 1.84 & 1.86 & 1.83 & 1.84 & 1.86 & 1.87 & 1.87 & 1.92 & 1.89 \\
\hline Portugal & 0.648 & 0.660 & 0.672 & 0.693 & 0.697 & 0.701 & 0.706 & 0.708 & 0.706 & 0.716 & 0.684 & 0.678 & 0.674 & 0.676 \\
\hline Slovak Republic & 0.432 & 0.443 & 0.455 & 0.470 & 0.501 & 0.526 & 0.522 & 0.528 & 0.555 & 0.572 & 0.566 & 0.567 & 0.568 & 0.564 \\
\hline Spain & 0.709 & 0.717 & 0.719 & 0.719 & 0.733 & 0.735 & 0.740 & 0.733 & 0.753 & 0.759 & 0.765 & 0.755 & 0.741 & 0.752 \\
\hline Sweden & 9.36 & 9.24 & 9.30 & 9.37 & 9.29 & 9.15 & 9.35 & 9.35 & 9.34 & 9.10 & 9.38 & 9.27 & 9.14 & 9.18 \\
\hline Switzerland & 1.98 & 1.94 & 1.89 & 1.88 & 1.87 & 1.85 & 1.84 & 1.77 & 1.78 & 1.75 & 1.74 & 1.69 & 1.66 & 1.63 \\
\hline Turkey & 0.024 & 0.043 & 0.076 & 0.131 & 0.202 & 0.283 & 0.428 & 0.613 & 0.773 & 0.812 & 0.831 & 0.861 & 0.892 & 0.952 \\
\hline United Kingdom & 0.64 & 0.64 & 0.63 & 0.64 & 0.65 & 0.64 & 0.63 & 0.63 & 0.64 & 0.63 & 0.64 & 0.64 & 0.65 & 0.66 \\
\hline United States & 1 & 1 & 1 & 1 & 1 & 1 & 1 & 1 & 1 & 1 & 1 & 1 & 1 & 1 \\
\hline Euro area & 0.901 & 0.907 & 0.890 & 0.883 & 0.888 & 0.879 & 0.870 & 0.868 & 0.874 & 0.871 & 0.859 & 0.852 & 0.845 & 0.850 \\
\hline OECD-Total & .. & .. & .. & .. & .. & .. & .. & .. & .. & .. & .. & .. & .. & .. \\
\hline
\end{tabular}

StatLink Aाs 
Table A.8. Exchange rates

National currency per US dollar

\begin{tabular}{|c|c|c|c|c|c|c|c|c|c|c|c|c|c|c|}
\hline & 1995 & 1996 & 1997 & 1998 & 1999 & 2000 & 2001 & 2002 & 2003 & 2004 & 2005 & 2006 & 2007 & 2008 \\
\hline Australia & 1.35 & 1.28 & 1.35 & 1.59 & 1.55 & 1.72 & 1.93 & 1.84 & 1.54 & 1.36 & 1.31 & 1.33 & 1.20 & 1.19 \\
\hline Austria & 0.733 & 0.769 & 0.887 & 0.900 & 0.939 & 1.090 & 1.120 & 1.060 & 0.886 & 0.805 & 0.804 & 0.797 & 0.731 & 0.683 \\
\hline Belgium & 0.731 & 0.768 & 0.887 & 0.900 & 0.939 & 1.090 & 1.120 & 1.060 & 0.886 & 0.805 & 0.804 & 0.797 & 0.731 & 0.683 \\
\hline Canada & 1.37 & 1.36 & 1.38 & 1.48 & 1.49 & 1.49 & 1.55 & 1.57 & 1.40 & 1.30 & 1.21 & 1.13 & 1.07 & 1.07 \\
\hline Czech Republic & 26.5 & 27.1 & 31.7 & 32.3 & 34.6 & 38.6 & 38.0 & 32.7 & 28.2 & 25.7 & 24.0 & 22.6 & 20.3 & 17.1 \\
\hline Denmark & 5.60 & 5.80 & 6.60 & 6.70 & 6.98 & 8.08 & 8.32 & 7.89 & 6.59 & 5.99 & 6.00 & 5.95 & 5.44 & 5.10 \\
\hline Finland & 0.734 & 0.773 & 0.873 & 0.899 & 0.939 & 1.090 & 1.120 & 1.060 & 0.886 & 0.805 & 0.804 & 0.797 & 0.731 & 0.683 \\
\hline France & 0.761 & 0.780 & 0.890 & 0.899 & 0.939 & 1.090 & 1.120 & 1.060 & 0.886 & 0.805 & 0.804 & 0.797 & 0.731 & 0.683 \\
\hline Germany & 0.733 & 0.769 & 0.887 & 0.900 & 0.939 & 1.090 & 1.120 & 1.060 & 0.886 & 0.805 & 0.804 & 0.797 & 0.731 & 0.683 \\
\hline Greece & 0.680 & 0.706 & 0.801 & 0.867 & 0.897 & 1.070 & 1.120 & 1.060 & 0.886 & 0.805 & 0.804 & 0.797 & 0.731 & 0.683 \\
\hline Hungary & 126.0 & 153.0 & 187.0 & 214.0 & 237.0 & 282.0 & 286.0 & 258.0 & 224.0 & 203.0 & 200.0 & 210.0 & 184.0 & 172.0 \\
\hline Iceland & 64.7 & 66.5 & 70.9 & 71.0 & 72.3 & 78.6 & 97.4 & 91.7 & 76.7 & 70.2 & 63.0 & 70.2 & 64.1 & 87.9 \\
\hline Ireland & 0.792 & 0.794 & 0.838 & 0.892 & 0.939 & 1.090 & 1.120 & 1.060 & 0.886 & 0.805 & 0.804 & 0.797 & 0.731 & 0.683 \\
\hline Italy & 0.841 & 0.797 & 0.880 & 0.897 & 0.939 & 1.090 & 1.120 & 1.060 & 0.886 & 0.805 & 0.804 & 0.797 & 0.731 & 0.683 \\
\hline Japan & 94 & 109 & 121 & 131 & 114 & 108 & 122 & 125 & 116 & 108 & 110 & 116 & 118 & 103 \\
\hline Korea & 771 & 804 & 951 & 1401 & 1189 & 1131 & 1291 & 1251 & 1192 & 1145 & 1024 & 955 & 929 & 1102 \\
\hline Luxembourg & 0.731 & 0.768 & 0.887 & 0.900 & 0.939 & 1.090 & 1.120 & 1.060 & 0.886 & 0.805 & 0.804 & 0.797 & 0.731 & 0.683 \\
\hline Mexico & 6.42 & 7.60 & 7.92 & 9.14 & 9.56 & 9.46 & 9.34 & 9.66 & 10.80 & 11.30 & 10.90 & 10.90 & 10.90 & 11.10 \\
\hline Netherlands & 0.729 & 0.765 & 0.885 & 0.900 & 0.939 & 1.090 & 1.120 & 1.060 & 0.886 & 0.805 & 0.804 & 0.797 & 0.731 & 0.683 \\
\hline New Zealand & 1.52 & 1.45 & 1.51 & 1.87 & 1.89 & 2.20 & 2.38 & 2.16 & 1.72 & 1.51 & 1.42 & 1.54 & 1.36 & 1.42 \\
\hline Norway & 6.34 & 6.45 & 7.07 & 7.55 & 7.80 & 8.80 & 8.99 & 7.98 & 7.08 & 6.74 & 6.44 & 6.41 & 5.86 & 5.64 \\
\hline Poland & 2.42 & 2.70 & 3.28 & 3.48 & 3.97 & 4.35 & 4.09 & 4.08 & 3.89 & 3.66 & 3.24 & 3.10 & 2.77 & 2.41 \\
\hline Portugal & 0.754 & 0.769 & 0.874 & 0.898 & 0.939 & 1.090 & 1.120 & 1.060 & 0.886 & 0.805 & 0.804 & 0.797 & 0.731 & 0.683 \\
\hline Slovak Republic & 0.986 & 1.020 & 1.120 & 1.170 & 1.370 & 1.530 & 1.610 & 1.500 & 1.220 & 1.070 & 1.030 & 0.986 & 0.820 & 0.709 \\
\hline Spain & 0.749 & 0.761 & 0.880 & 0.898 & 0.939 & 1.090 & 1.120 & 1.060 & 0.886 & 0.805 & 0.804 & 0.797 & 0.731 & 0.683 \\
\hline Sweden & 7.13 & 6.71 & 7.63 & 7.95 & 8.26 & 9.16 & 10.30 & 9.74 & 8.09 & 7.35 & 7.47 & 7.38 & 6.76 & 6.59 \\
\hline Switzerland & 1.18 & 1.24 & 1.45 & 1.45 & 1.50 & 1.69 & 1.69 & 1.56 & 1.35 & 1.24 & 1.25 & 1.25 & 1.20 & 1.08 \\
\hline Turkey & 0.046 & 0.081 & 0.152 & 0.261 & 0.419 & 0.625 & 1.230 & 1.510 & 1.500 & 1.430 & 1.340 & 1.430 & 1.300 & 1.300 \\
\hline United Kingdom & 0.63 & 0.64 & 0.61 & 0.60 & 0.62 & 0.66 & 0.70 & 0.67 & 0.61 & 0.55 & 0.55 & 0.54 & 0.50 & 0.54 \\
\hline United States & 1 & 1 & 1 & 1 & 1 & 1 & 1 & 1 & 1 & 1 & 1 & 1 & 1 & 1 \\
\hline Euro area & 0.765 & 0.788 & 0.882 & 0.892 & 0.939 & 1.090 & 1.120 & 1.060 & 0.886 & 0.805 & 0.804 & 0.797 & 0.731 & 0.683 \\
\hline OECD-Total & .. & .. & .. & .. & .. & .. & .. & .. & .. & .. & .. & .. & .. & .. \\
\hline
\end{tabular}

StatLink क्ञाs http://dx.doi.org/10.1787/741687552807 

Annex B: The 2008 SNA - Changes from the 1993 SNA 
Although the indicators presented in this publication are based on the 1993 SNA, the 2008 SNA has recently been finalised and includes a number of changes to the 1993 SNA. Although it will be a number of years (2014 for most countries) before the national accounts and this publication reflect these changes, it is all the same instructive to present the key changes (those that will eventually impact on the indicators presented in this publication) here.

\section{Changes affecting whole economy levels of income, etc.}

Research and experimental development: $R \& D$ is recognised for the first time as a produced asset. This also means that payments for the acquisition of patents, treated as acquisition or disposal of non produced, nonfinancial assets in the 1993 SNA, will be treated as transactions in produced assets, R\&D. This also has implications for sectoral GVA as the 2008 SNA also recommends that a separate establishment is distinguished for R\&D producers when possible. See also the OECD Handbook on Deriving Capital Measures of Intellectual Property Products.

Weapons systems: Military weapons systems such as vehicles, warships etc used continuously in the production of defence (and deterrence) services are recognised as fixed assets in the 2008 SNA (the 1993 SNA recorded these as fixed assets only if they had dual civilian use and as intermediate consumption otherwise). Some single-use items such as certain types of ballistic missiles with a highly destructive capability, but which provide on-going deterrence services, are also recognised as fixed assets in the 2008 SNA. Because most if not all of these expenditures are carried out by government (whose output is typically valued by summing costs) GDP will only increase by the related new consumption of fixed capital.

FISIM: The method recommended in the 2008 SNA for the calculation of FISIM implies several changes from that in the 1993 SNA. For example it explicitly recommends that FISIM only applies to loans and deposits provided by/deposited with financial institutions, and that for financial intermediaries all loans and deposites are included, not just those of intermediated funds. In addition, the 2008 SNA no longer allows countries to record FISIM as a notional industry.

Financial services: The 2008 SNA defines financial services more explicitly to ensure that services such as financial risk management and liquidity transformation, are captured.

Ouput of non-life insurance services: The methodology used to indirectly estimate this activity in the 1993 SNA (the balance of premiums, premium supplements, and claims) could lead to extremely volatile (and negative) series in cases of catastrophic losses. The 2008 SNA recommends a different indirect approach to measurement that better reflects the pricing structures used by insurance companies and the underlying provision of insurance services per se. The approach can be simply described as an ex ante expectation approach. Output is equal to premiums plus expected premium supplements minus expected claims. The 2008 SNA also recommends that exceptionally large claims, following a catastrophe, are recorded as capital, rather than current, transfers which will have an impact on (particularly sectoral) estimates of disposable income.

Output of Central Banks: The 2008 SNA has provided further clarification on the calculation of FISIM in calculating the output of Centrals Banks. Where Central Banks lend or borrow at rates above or below the effective market lending/borrowing rate the 2008 SNA recommends the recording of a tax or subsidy from the counterpart lender/borrower to/from government to reflect the difference between the two rates. Correspondingly a current transfer (the counterpart to the tax/subsidy) is recorded between government and the Central Bank. These flows will have 
an impact on the distribution of income in national income compared to the 1993 SNA treatment.

Valuation of output for own final use: The 2008 SNA recommends that estimates of output for own final use should include a component for the return to capital as part of the sum of costs approach when comparable market prices are not available. However no return to capital should be included for non-market producers.

Costs of ownership transfer: The 1993 SNA recommended that these costs (treated as GFCF in the accounts) should be written off over the life of the related asset. The 2008 SNA instead recommends that these costs be written off over the period the asset is expected to be held by the purchaser. This will impact on measures of net income and only marginally on gross measures, reflecting the calculation of output for own final use and government output (which is calculated as the sum of costs including depreciation).

\section{Re-allocating income etc across categories}

Goods sent aborad for reprocessing: The 2008 SNA recommends that imports and exports are recorded on a strict ownership basis. This means that the values of a flow of goods moving from one country (that retains ownership of the goods) to another providing processing services should not be recorded. Only the charge for the processing service should be recorded in the trade statistics. The 1993 SNA imputed an effective change of ownership.

(Pensions) Defined benefit schemes: The 1993 SNA stated that actual social contributions by employers and employees should reflect the amounts actually paid. The 2008 SNA differs, recognising that the amounts actually set aside may not match the liability to the employees. As such the 2008 SNA recommends that the employer's contribution should reflect the increase in the net present value of the pension entititlement plus costs charged by the pension fund minus the employee's own contributions. This change will result in a shift of income between gross operating surplus and compensation of employees and between institutional sectors (corporations/government and households).

Ancillary activities: The 2008 SNA recommends that if the activity of a unit undertaking purely ancillary activities is statistically observable (separate accounts, separate location) it should be recognised as a separate establishment.

Holding companies: The 2008 SNA recommends that holding companies should always be allocated to the financial corprorations sector even if all their subsidiary corporations are nonfinancial corporations. The 1993 SNA recommended that they were assigned to the institutional sector in which the main group of subsidiaries was concentrated.

Exceptional payments from public corporations: The 2008 SNA recommends that these should be recorded as withdrawls from equity when made from accumulated reserves or sales of assets. The 1993 SNA treated such transactions as dividends.

Exceptional payments from governments to quasi public corporations: The 2008 SNA recommends that these should be treated as capital transfers to cover accumulated losses and as additions to equity when a valid expectation of a return in the form of property income exists. The 1993 SNA treated all such payments as additions to equity. 



\section{Annex C: Glossary of Main Terms}




\section{GLOSSARY OF MAIN TERMS}

\section{SYSTEM OF NATIONAL ACCOUNTS, 1993}

The definitions in this Glossary are based on the actual wording used in the System of National Accounts, 1993 (SNA93). Where applicable, each definition shows the paragraph of SNA93 from which the definition has been derived.

\begin{tabular}{|c|c|c|}
\hline Term & Definition & Paragraph(s) \\
\hline Capital transfers & $\begin{array}{l}\text { Capital transfers are transactions, either in cash or in kind, in which the ownership of an asset (other than } \\
\text { cash and inventories) is transferred from one institutional unit to another, or in which cash is transferred to } \\
\text { enable the recipient to acquire another asset, or in which the funds realised by the disposal of another asset } \\
\text { are transferred. }\end{array}$ & $\begin{array}{r}10.29 \\
{[3.22,8.3]}\end{array}$ \\
\hline Chain indices & $\begin{array}{l}\text { Chain indices are obtained by linking price (or volume) indices for consecutive periods; the short-term } \\
\text { movements which are linked are calculated using weighting patterns appropriate to the periods concerned. }\end{array}$ & 16.41 \\
\hline $\begin{array}{l}\text { Changes in inventories } \\
\text { (including work-in-progress) }\end{array}$ & $\begin{array}{l}\text { Changes in inventories (including work-in-progress) consist of changes in: a) stocks of outputs that are still } \\
\text { held by the units that produced them prior to their being further processed, sold, delivered to other units or } \\
\text { used in other ways; and } b \text { ) stocks of products acquired from other units that are intended to be used for } \\
\text { intermediate consumption or for resale without further processing; they are measured by the value of the } \\
\text { entries into inventories less the value of withdrawals and the value of any recurrent losses of goods held in } \\
\text { inventories. }\end{array}$ & 10.7 and 10.28 \\
\hline $\begin{array}{l}\text { Collective consumption } \\
\text { service }\end{array}$ & $\begin{array}{l}\text { A collective consumption service is a service provided by general government simultaneously to all } \\
\text { members of the community or to all members of a particular section of the community, such as all } \\
\text { households living in a particular region. }\end{array}$ & 9.43 \\
\hline Compensation of employees & $\begin{array}{l}\text { Compensation of employees is the total remuneration, in cash or in kind, payable by enterprises to } \\
\text { employees in return for work done by the latter during the accounting period. }\end{array}$ & $\begin{array}{r}7.21 \\
{[7.31]}\end{array}$ \\
\hline Constant prices & $\begin{array}{l}\text { Constant prices are obtained by directly factoring changes over time in the values of flows or stocks of goods } \\
\text { and services into two components reflecting changes in the prices of the goods and services concerned and } \\
\text { changes in their volumes (i.e. changes in "constant price terms"); the term "at constant prices" commonly } \\
\text { refers to series which use a fixed-base Laspeyres formula. }\end{array}$ & 16.2 \\
\hline Consumption of fixed capital & $\begin{array}{l}\text { Consumption of fixed capital represents the reduction in the value of the fixed assets used in production } \\
\text { during the accounting period resulting from physical deterioration, normal obsolescence or normal } \\
\text { accidental damage. }\end{array}$ & $\begin{array}{r}10.27 \\
{[6.179,10.118]}\end{array}$ \\
\hline Current transfers & $\begin{array}{l}\text { Current transfers consist of all transfers that are not transfers of capital; they directly affect the level of } \\
\text { disposable income and should influence the consumption of goods or services. }\end{array}$ & $\begin{array}{r}8.32 \\
{[3.22,8.3,10.133]}\end{array}$ \\
\hline $\begin{array}{l}\text { Current transfers from/to } \\
\text { abroad }\end{array}$ & $\begin{array}{l}\text { Current transfers which take place between resident and non-resident institutional units are referred to as } \\
\text { current transfers from/to abroad. }\end{array}$ & 8.4 \\
\hline Disposable income & $\begin{array}{l}\text { Disposable income is derived from the balance of primary incomes of an institutional unit or sector by adding } \\
\text { all current transfers, except social transfers in kind, receivable by that unit or sector and subtracting all } \\
\text { current transfers, except social transfers in kind, payable by that unit or sector; it is the balancing item in the } \\
\text { Secondary Distribution of Income Account. }\end{array}$ & 8.11 \\
\hline Disposals & $\begin{array}{l}\text { Disposals of assets (inventories, fixed assets or land or other non-produced assets) by institutional units } \\
\text { occur when one of those units sells or transfers any of the assets to another institutional unit; when the } \\
\text { ownership of an existing fixed asset is transferred from one resident producer to another, the value of the } \\
\text { asset sold, bartered or transferred is recorded as negative gross fixed capital formation by the former and as } \\
\text { positive gross fixed capital formation by the latter. }\end{array}$ & $\begin{array}{r}10.40 \\
{[9.32]}\end{array}$ \\
\hline Employee & $\begin{array}{l}\text { An employee is a person who enters an agreement, which may be formal or informal, with an enterprise to } \\
\text { work for the enterprise in return for remuneration in cash or in kind. }\end{array}$ & 7.23 \\
\hline $\begin{array}{l}\text { Exports of goods and } \\
\text { services }\end{array}$ & $\begin{array}{l}\text { Exports of goods and services consist of sales, barter, or gifts or grants, of goods and services from } \\
\text { residents to non-residents; the treatment of exports and imports in the SNA is generally identical with that in } \\
\text { the balance of payments accounts as described in the Balance of Payments Manual. }\end{array}$ & $\begin{array}{r}14.88 \\
{[14.91,14.94]}\end{array}$ \\
\hline $\begin{array}{l}\text { External balance of goods } \\
\text { and services }\end{array}$ & $\begin{array}{l}\text { The external balance of goods and services is the value of exports of goods and services less imports of } \\
\text { goods and services. }\end{array}$ & 2.166 and Table 2.3 V.I \\
\hline
\end{tabular}




\begin{tabular}{|c|c|}
\hline Term & Definition \\
\hline Factor cost & $\begin{array}{l}\text { Gross value added at factor cost is not a concept used explicitly in the SNA but it can easily be derived by } \\
\text { subtracting the value of any taxes, less subsidies, on production payable out of gross value added. }\end{array}$ \\
\hline Final consumption & $\begin{array}{l}\text { Final consumption consists of goods and services used up by individual households or the community to } \\
\text { satisfy their individual or collective needs or wants. }\end{array}$ \\
\hline $\begin{array}{l}\text { Final consumption } \\
\text { expenditure of government }\end{array}$ & $\begin{array}{l}\text { Government final consumption expenditure consists of expenditure, including imputed expenditure, incurred } \\
\text { by general government on both individual consumption goods and services and collective consumption } \\
\text { services. }\end{array}$ \\
\hline $\begin{array}{l}\text { Final consumption } \\
\text { expenditure of households }\end{array}$ & $\begin{array}{l}\text { Household final consumption expenditure consists of the expenditure, including imputed expenditure, } \\
\text { incurred by resident households on individual consumption goods and services, including those sold at } \\
\text { prices that are not economically sizgnificant. }\end{array}$ \\
\hline $\begin{array}{l}\text { Final consumption } \\
\text { expenditure of NPISHs }\end{array}$ & $\begin{array}{l}\text { Final consumption expenditure of NPISHs consists of the expenditure, including imputed expenditure, } \\
\text { incurred by resident NPISHs on individual consumption goods and services. }\end{array}$ \\
\hline $\begin{array}{l}\text { Financial intermediation } \\
\text { services indirectly measure }\end{array}$ & $\begin{array}{l}\text { Financial intermediation services indirectly measured (FISIM) is an indirect measure of the value of financial } \\
\text { intermediation services provided but for which financial institutions do not charge explicitly. }\end{array}$ \\
\hline
\end{tabular}
(FISIM)

Full-time equivalent employment General government

Government final consumption expenditure

Gross

Gross capital formation

Gross domestic product (GDP) - expenditure based Gross domestic product (GDP) - income based Gross domestic product (GDP) - output based Gross domestic product at market prices

Full-time equivalent employment is the number of full-time equivalent jobs, defined as total hours worked divided by average annual hours worked in full-time jobs.

The general government sector consists of the totality of institutional units which, in addition to fulfilling their political responsibilities and their role of economic regulation, produce principally non-market services (possibly goods) for individual or collective consumption and redistribute income and wealth.

Government final consumption expenditure consists of expenditure, including imputed expenditure, incurred by general government on both individual consumption goods and services and collective consumption services.

The term "gross" is a common means of referring to values before deducting consumption of fixed capital (generally used as in "gross capital stock" or "gross domestic product"); all the major balancing items in the accounts from value added through to saving may be recorded gross or net.

Gross capital formation is measured by the total value of the gross fixed capital formation, changes in inventories and acquisitions less disposals of valuables for a unit or sector.

Expenditure-based gross domestic product is total final expenditures at purchasers' prices (including the f.o.b. value of exports of goods and services), less the f.o.b. value of imports of goods and services.

Income-based gross domestic product is compensation of employees, plus taxes less subsidies on production and imports, plus gross mixed income, plus gross operating surplus.

Output-based gross domestic product is the sum of the gross values added of all resident producers at basic prices, plus all taxes less subsidies on products.

Gross fixed capital formation Gross fixed capital formation is measured by the total value of a producer's acquisitions, less disposals, of fixed assets during the accounting period plus certain additions to the value of non-produced assets (such as subsoil assets or major improvements in the quantity, quality or productivity of land) realised by the productive activity of institutional units.

Gross national disposable Gross national disposable income may be derived from gross national income by adding all current transfers income in cash or in kind receivable by resident institutional units from non-resident units and subtracting all current transfers in cash or in kind payable by resident institutional units to non-resident units.

Gross national income (GNI) Gross national income (GNI) is GDP less net taxes on production and imports, less compensation of employees and property income payable to the rest of the world plus the corresponding items receivable from the rest of the world (in other words, GDP less primary incomes payable to non-resident units plus primary incomes receivable from non-resident units); an alternative approach to measuring GNI at market prices is as the aggregate value of the balances of gross primary incomes for all sectors; (note that gross national income is identical to gross national product (GNP) as previously used in national accounts generally).

Gross saving Gross saving is gross disposable income less final consumption expenditure.

Gross value added

Gross value added is the value of output less the value of intermediate consumption; it is a measure of the contribution to GDP made by an individual producer, industry or sector; gross value added is the source from which the primary incomes of the SNA are generated and is therefore carried forward into the primary distribution of income account.

Gross value added at basic Gross value added at basic prices is output valued at basic prices less intermediate consumption valued at prices purchasers' prices.

Gross value added at Gross value added at producers' prices is output valued at producers' prices less intermediate consumption producers' prices valued at purchasers' prices.

Household final consumption Household final consumption expenditure consists of the expenditure, including imputed expenditure, expenditure incurred by resident households on individual consumption goods and services, including those sold at prices that are not economically significant. 


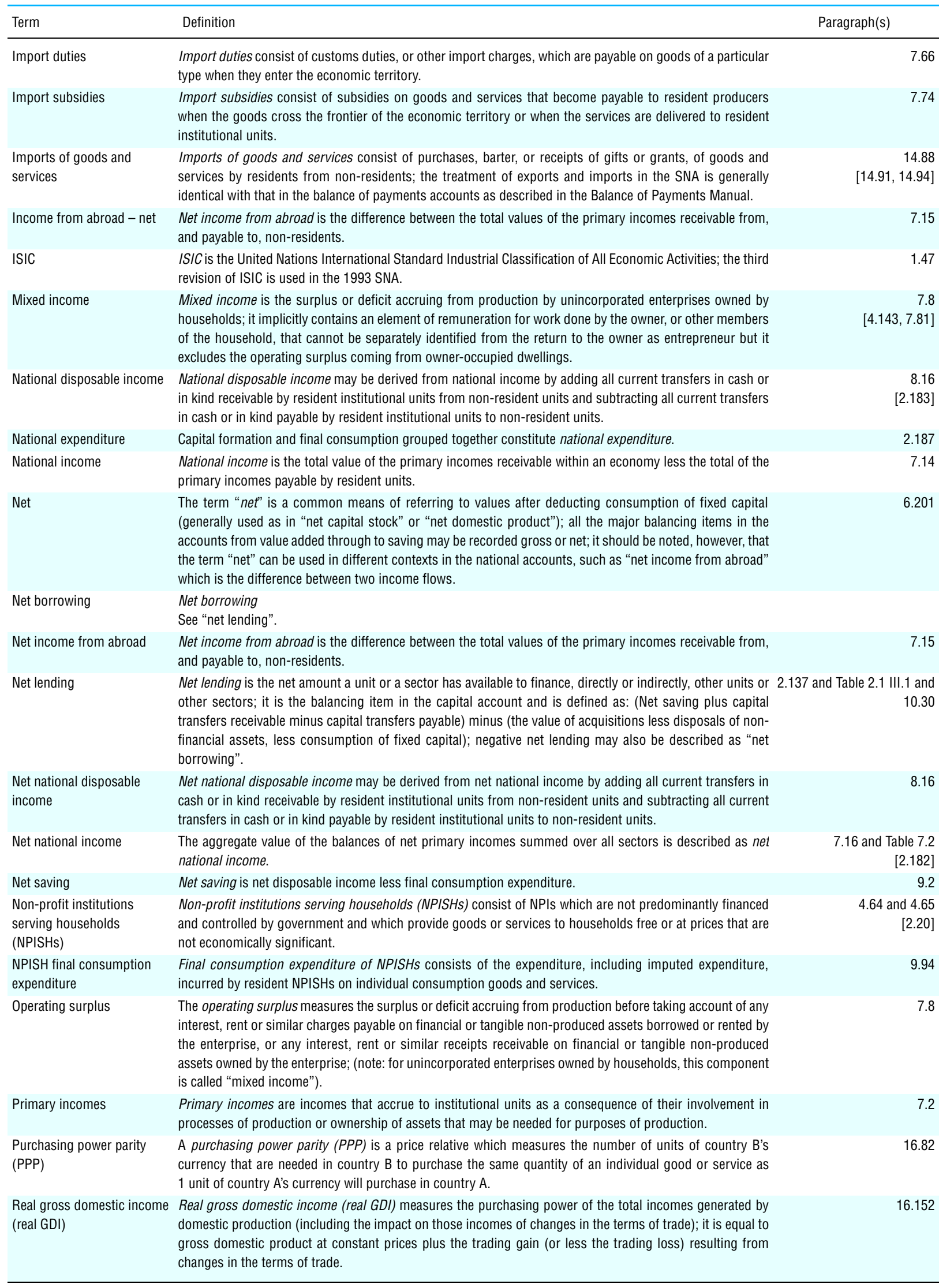




\section{Term} Definition

Rebasing

Saving

Self-employed workers

SNA (System of National Accounts)

Subsidies

Subsidies on production other

Subsidies on products other corporations.

In the course of time, the pattern of relative prices in the base period tends to become progressively less relevant to the economic situations of later periods to the point at which it becomes unacceptable to continue using them to measure volume measures from one period to the next; it may then be necessary to update the base period, a process which is commonly referred to as "rebasing".

Saving is disposable income less final consumption expenditure (or adjusted disposable income less actual final consumption), in both cases after taking account of an adjustment for pension funds; saving is an important aggregate which can be calculated for each institutional sector or for the whole economy.

Self-employed workers are persons who are the sole owners, or joint owners, of the unincorporated enterprises in which they work, excluding those unincorporated enterprises that are classified as quasi-

The System of National Accounts (SNA) consists of a coherent, consistent and integrated set of macroeconomic accounts, balance sheets and tables based on a set of internationally agreed concepts, definitions, classifications and accounting rules.

Subsidies are current unrequited payments that government units, including non-resident government units, make to enterprises on the basis of the levels of their production activities or the quantities or values of the goods or services which they produce, sell or import.

Paragraph(s)

Other subsidies on production consist of subsidies, except subsidies on products, which resident enterprises may receive as a consequence of engaging in production (e.g. subsidies on payroll or workforce or subsidies to reduce pollution).

Other subsidies on products (other than export or import subsidies) consist of subsidies on goods or services produced as the outputs of resident enterprises that become payable as a result of the production, sale, transfer, leasing or delivery of those goods or services, or as a result of their use for own consumption or own capital formation; there are three broad categories: a) subsidies on products used domestically, b) losses of government trading organisations, and c) subsidies to public corporations and quasicorporations.

System of National Accounts The System of National Accounts (SNA) consists of a coherent, consistent and integrated set of (SNA) macroeconomic accounts, balance sheets and tables based on a set of internationally agreed concepts, definitions, classifications and accounting rules.

Taxes

Taxes are compulsory, unrequited payments, in cash or in kind, made by institutional units to government units; they are described as unrequited because the government provides nothing in return to the individual unit making the payment, although governments may use the funds raised in taxes to provide goods or services to other units, either individually or collectively, or to the community as a whole.

Taxes on production and Taxes on production and imports consist of taxes payable on goods and services when they are produced, imports delivered, sold, transferred or otherwise disposed of by their producers plus taxes and duties on imports that become payable when goods enter the economic territory by crossing the frontier or when services are delivered to resident units by non-resident units; they also include other taxes on production, which consist mainly of taxes on the ownership or use of land, buildings or other assets used in production or on the labour employed, or compensation of employees paid.

Taxes on products

Taxes on products, excluding VAT, import and export taxes, consist of taxes on goods and services that become payable as a result of the production, sale, transfer, leasing or delivery of those goods or services, or as a result of their use for own consumption or own capital formation.

Total final consumption Total final consumption is the total value of all expenditures on individual and collective consumption goods and services incurred by resident households, resident NPISHs and general government units; it may also be defined in terms of actual final consumption as the value of all the individual goods and services acquired by resident households plus the value of the collective services provided by general government to the community or large sections of the community.

Trading gains and losses Trading gains and losses arise from changes in a country's terms of trade; for example, if the prices of a country's exports rise faster (or fall more slowly) than the prices of its imports (i.e. if its terms of trade improve) then an increased volume of imports of goods and services can be purchased by residents out of the receipts generated by a given level of exports.

Valuables Valuables are produced assets that are not used primarily for production or consumption, that are expected to appreciate or at least not to decline in real value, that do not deteriorate over time under normal conditions and that are acquired and held primarily as stores of value.

Wages and salaries Wages and salaries consist of the sum of wages and salaries in cash and wages and salaries in kind.

Wages and salaries in cash Wages and salaries in cash consist of wages or salaries payable at regular weekly, monthly or other intervals, including payments by results and piecework payments; plus allowances such as those for working overtime; plus amounts paid to employees away from work for short periods (e.g. on holiday); plus ad hoc bonuses and similar payments; plus commissions, gratuities and tips received by employees.

Wages and salaries in kind Wages and salaries in kind consist of remuneration in the form of goods and/or services that are not necessary for work and can be used by employees in their own time, and at their own discretion, for the satisfaction of their own needs or wants or those of other members of their households. 
OECD PUBLISHING, 2, rue André-Pascal, 75775 PARIS CEDEX 16 PRINTED IN FRANCE

(30 2009141 P) ISBN 978-92-64-06721-9 - No. 569412009 


\section{National Accounts at a Glance 2009}

National Accounts at a Glance is a new publication of the OECD, which presents information using an "indicator" approach, focusing on cross-country comparisons; the aim being to make the national accounts more accessible and informative, whilst, at the same time, taking the opportunity to present the conceptual underpinning of, and comparability issues inherent in, each of the indicators presented.

A dynamic link (StatLink) is provided for each table directing the user to a webpage where the corresponding data are available in Excel ${ }^{\circledR}$ format.

The range of indicators reflects the richness inherent in the national accounts dataset and encourages users to refocus some of the spotlight that is often placed on GDP to other economic important indicators, which may better respond to their needs. The publication is broken down into seven key chapters, and provides indicators related to income, expenditure, production, government and capital respectively.

The full text of this book is available on line via these links: www.sourceoecd.org/nationalaccounts/9789264067219 www.sourceoecd.org/statisticssourcesmethods/9789264067219

Those with access to all OECD books on line should use this link: www.sourceoecd.org/9789264067219

SourceOECD is the OECD online library of books, periodicals and statistical databases.

For more information about this award-winning service and free trials ask your librarian, or write to us at SourceOECD@oecd.org. 